\begin{tabular}{|c|c|c|c|}
\hline $\begin{array}{l}\text { Date Submitted: } \frac{08 / 27 / 08}{} \\
\text { Originator: } \quad \text { J. M. Capron } \\
\text { Phone: } \quad 372-9227\end{array}$ & \multicolumn{2}{|c|}{$\begin{array}{l}\text { WASTE SITE RECLASSIFICATION FORM } \\
\text { Operable Unit(s): } \quad \text { 100-IU-6 } \\
\text { Waste Site Code: } \quad \text { 600-111 } \\
\text { Type of Reclassification Action: } \\
\text { Closed Out } \square \quad \text { Interim Closed Out } \otimes \text { No Action } \square \\
\text { RCRA Postclosure } \square \quad \text { Rejected } \square \text { Consolidated } \square\end{array}$} & Control Number: $2004-065$ \\
\hline \multicolumn{4}{|c|}{$\begin{array}{l}\text { This form documents agreement among parties listed authorizing classification of the subject unit as Closed Out, Interim Closed } \\
\text { Out, No Action, RCRA Postclosure, Rejected, or Consolidated. This form also authorizes backfill of the waste management unit, } \\
\text { if appropriate, for Closed Out and Interim Closed Out units. Final removal from the NPL of No Action and Closed Out waste } \\
\text { management units will occur at a future date. }\end{array}$} \\
\hline \multicolumn{4}{|c|}{$\begin{array}{l}\text { The 600-111, P-11 Critical Mass Laboratory Crib waste site, also referred to as the P-11 Facility, included the } 120 \text { Experimental } \\
\text { Building, the } 123 \text { Control Building (including a septic system), and the P-11 Crib. The facility was constructed in } 1949 \text { and was } \\
\text { used as a laboratory for plutonium criticality studies. In November } 1951 \text {, a criticality resulted in extensive plutonium } \\
\text { contamination inside the laboratory building (120 Experimental Building). Activities in the building were suspended to conduct } \\
\text { decontamination work. On December 4, 1951, decontamination activities were in the final stages when a spontaneous ignition of } \\
\text { decontamination materials caused a fire that gutted the entire building. Plutonium contamination was spread by the fire and was } \\
\text { also washed into the soil by the water used to suppress the fire (identified as UPR-600-16). The area was stabilized with clean } \\
\text { soil and gravel to prevent wind from spreading the contamination further. The } 120 \text { Experimental Building and its crib were } \\
\text { removed in } 1974 \text { and the area was released from radiological posting. }\end{array}$} \\
\hline \multicolumn{4}{|c|}{$\begin{array}{l}\text { Confirmatory sampling, remediation and verification sampling of the 600-111 waste site has been performed in accordance with } \\
\text { remedial action objectives and goals established by the Interim Action Record of Decision for the 100-BC-1,100-BC-2, } \\
100-D R-1,100-D R-2,100-F R-1,100-F R-2,100-H R-1, J 00-H R-2,100-K R-1,100-K R-2,100-I U-2,100-I U-6, \text { and } 200-C W-3 \\
\text { Operable Units, Hanford Site, Benton County, Washington (Remaining Sites ROD), U.S. Environmental Protection Agency, } \\
\text { Region 10, Seattle, Washington. The selected remedial action involved (1) evaluating the site using available process } \\
\text { information and confirmatory sampling data, (2) remediating the site, (3) demonstrating through verification sampling that } \\
\text { cleanup goals have been achieved, and (4) proposing the site for reclassification as Interim Closed Out. }\end{array}$} \\
\hline \multicolumn{4}{|l|}{ Basis for reclassification: } \\
\hline \multicolumn{4}{|c|}{$\begin{array}{l}\text { In accordance with this evaluation, the confirmatory and verification sampling results support a reclassification of the } 600-111 \\
\text { waste site to Interim Closed Out. The current site conditions achieve the remedial action objectives and the corresponding } \\
\text { remedial action goals established in the Remaining Sites ROD. The results of confirmatory and verification sampling show that } \\
\text { residual contaminant concentrations do not preclude any future uses (as bounded by the rural-residential scenario) and allow for } \\
\text { unrestricted use of shallow zone soils (i.e., surface to } 4.6 \mathrm{~m}[15 \mathrm{ft}] \text { deep). The results also demonstrate that residual contaminant } \\
\text { concentrations are protective of groundwater and the Columbia River. Site contamination did not extend into the deep zone } \\
\text { soils; therefore, institutional controls to prevent uncontrolled drilling or excavation into the deep zone are not required. The } \\
\text { basis for reclassification is described in detail in the Remaining Sites Verification Package for the } 600-111, \text { P-1] Critical Mass } \\
\text { Laboratory Crib, and UPR-600-16, Fire and Contamination Spread Waste Sites (attached). }\end{array}$} \\
\hline \multicolumn{4}{|c|}{$\begin{array}{l}\text { Waste Site Controls: } \\
\text { Engineered Controls: Yes } \square \text { No } \square \quad \text { Institutional Controls: Yes } \square \text { No } \square \quad \text { O\&M requirements: Yes } \square \text { No } \square \\
\text { If any of the Waste Site Controls are checked Yes specify control requirements including reference to the Record of Decision, } \\
\text { TSD Closure Letter, or other relevant documents. }\end{array}$} \\
\hline \multicolumn{4}{|l|}{ M. S. French } \\
\hline DOE Federal Project Director & rinte & & Date \\
\hline Ecology Project Manager (prir & & $\begin{array}{l}\text { Signature } \\
\text { Otonyy }\end{array}$ & $\begin{array}{l}\text { Date } \\
10-28-08\end{array}$ \\
\hline EPA Project Manager (printed & & Signature & Date \\
\hline
\end{tabular}


Rev. 0

REMAINING SITES VERIFICATION PACKAGE FOR THE 600-111, P-11 CRITICAL MASS LABORATORY CRIB, AND UPR-600-16, FIRE AND CONTAMINATION SPREAD WASTE SITES

Attachment to Waste Site Reclassification Form 2004-065 and $2008-045^{-f \mathcal{C}}$

November 2008 


\section{REMAINING SITES VERIFICATION PACKAGE FOR THE 600-111, P-11 CRITICAL MASS LABORATORY CRIB, AND UPR-600-16, FIRE AND CONTAMINATION SPREAD WASTE SITES}

\section{EXECUTIVE SUMMARY}

The 600-111, P-11 Critical Mass Laboratory Crib, and UPR-600-16, Fire and Contamination Spread waste sites are located approximately $4.8 \mathrm{~km}(3 \mathrm{mi})$ south-southeast of the $100-\mathrm{F}$ Area and $0.5 \mathrm{~km}(0.3 \mathrm{mi})$ west of Route 2 North. The $600-111$ site includes the area where the 120 Experimental Building, 123 Control Building (including septic system), and P-11 Crib were located, collectively known as the P-11 Critical Mass Laboratory and Crib or P-11 Facility. The P-11 Facility was used as a laboratory for plutonium criticality studies. In November 1951, a criticality resulted in extensive plutonium contamination inside the laboratory building (120 Experimental Building). During decontamination activities, a spontaneous ignition of decontamination materials caused a fire that gutted the entire building. The 120 Experimental Building, 123 Control Building, and P-11 Crib were removed in 1974, and the area was released from radiological posting. The UPR-600-16 waste site is an unplanned release associated with the fire at the 120 Experimental Building (600-111).

A stratified confirmatory sampling design (BHI 2004d) using focused sampling of worst-case locations of suspect contamination was used to evaluate the site. The results of the sampling were used to support a decision about reclassifying the site in accordance with the waste site reclassification guideline TPA-MP-14 process (DOE-RL 2007).

Confirmatory sampling was performed April 29, 2004, through May 10, 2004. Historical information, construction drawings, and geophysical survey data provided the basis for determining sample locations presented in the confirmatory sample design (BHI 2004d). Deviations from the confirmatory sample design are documented in this report and resulted from information gathered during the confirmatory sampling effort. Test pits and trenches were excavated in six areas to expose the subsurface for visual inspection and confirmatory sample collection. Each confirmatory sample result was directly compared against the cleanup criteria to support decisions concerning waste site reclassification. The confirmatory sampling results indicated that the septic system, including the septic tank and the septic drain field associated with the 123 Building, required removal due to the presence of polychlorinated biphenyls, arsenic, cadmium, and lead exceeding the direct exposure remedial action goals. Laboratory analysis of confirmatory samples collected within the building footprint of the former 123 Control Building, the removed P-11 Crib, and the building footprint of the former 120 Experimental Building met the remedial action goals, and, therefore, no additional remedial action in these areas was necessary. An extensive radiological survey of the entire surface soil at the site found no localized or area-wide contamination with all measurements below background radiation levels.

Remedial action of the septic system tank and drain field located at the 600-111 waste site was performed between February 25, 2008 and March 25, 2008. The site was excavated to approximately $4.6 \mathrm{~m}$ (15 ft) below grade (at the deepest portion), resulting in a combined volume 
of approximately $2,755 \mathrm{~m}^{3}\left(3,603 \mathrm{yd}^{3}\right)$ of material removed and disposed at the Environmental Restoration Disposal Facility.

Verification soil samples for the septic system remediation were collected on April 21, 2008. A summary of the evaluation of the statistical verification soil sample results for the septic system and the 2004 focused confirmatory sample results for the former 123 Control Building, the removed P-11 Crib, and the footprint of the former 120 Experimental Building against the applicable cleanup criteria is presented in Table ES-1. The results of the confirmatory sampling and the verification sampling are used to make reclassification decisions for the 600-111 and UPR-600-16 waste sites in accordance with the Tri-Party Agreement Handbook Management Procedures, TPA-MP-14 (DOE-RL 2007).

In accordance with this evaluation, the confirmatory and verification sampling results support a reclassification of this site to Interim Closed Out. The current site conditions achieve the remedial action objectives and the corresponding remedial action goals established in the Remedial Design Report/Remedial Action Work Plan for the 100 Area (DOE-RL 2005b) and the Interim Action Record of Decision for the 100-BC-1, 100-BC-2, 100-DR-1, 100-DR-2, 100-FR-1, 100-FR-2, 100-HR-1, 100-HR-2, 100-KR-1, 100-KR-2, 100-IU-2, 100-IU-6, and 200-CW-3

Operable Units, Hanford Site, Benton County, Washington (EPA 1999). These results show that residual soil concentrations support future land uses that can be represented (or bounded) by a rural-residential scenario. The results also demonstrate that residual contaminant concentrations

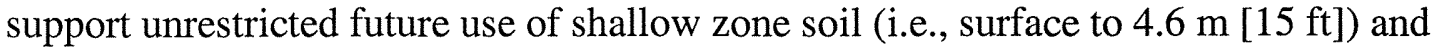
contaminant levels remaining in the soil are protective of groundwater and the Columbia River. The site does not have a deep zone or residual contaminant concentrations that would require any institutional controls.

A comparison against ecological risk screening levels has been made for the site contaminants of potential concern and other constituents. Screening levels were exceeded for antimony, arsenic, barium, boron, copper, lead, manganese, mercury, vanadium, and zinc. Exceedance of screening values does not necessarily indicate the existence of risk to ecological receptors. It is believed that the presence of these constituents does not pose a risk to ecological receptors because concentrations of antimony, arsenic, manganese, mercury, and vanadium are below site background levels, and barium, boron, copper, and mercury concentrations are consistent with those seen elsewhere at the Hanford Site (no established background value is available for boron). Lead and zinc present at concentrations exceeding background were detected in a single worst-case focused sample of burnt debris and will be evaluated in the context of additional lines of evidence for ecological effects as part of the final closeout for this site. 
Table ES-1. Summary of Contaminants of Potential Concern for the 600-111 and UPR-600-16 Sites.

\begin{tabular}{|c|c|c|c|}
\hline $\begin{array}{l}\text { Regulatory } \\
\text { Requirement }\end{array}$ & Remedial Action Goals & Results & $\begin{array}{c}\text { Remedial Action } \\
\text { Objectives } \\
\text { Attained? } \\
\end{array}$ \\
\hline $\begin{array}{l}\text { Direct Exposure - } \\
\text { Radionuclides }\end{array}$ & $\begin{array}{l}\text { Attain } 15-\mathrm{mrem} / \mathrm{yr} \text { dose rate } \\
\text { above background over } \\
1,000 \text { years. }\end{array}$ & $\begin{array}{l}\text { Maximum dose rate calculated by } \\
\text { RESRAD is } 1.32 \mathrm{mrem} / \mathrm{yr} \text {. }\end{array}$ & Yes \\
\hline $\begin{array}{l}\text { Direct Exposure - } \\
\text { Nonradionuclides }\end{array}$ & Attain individual COPC RAGs. & $\begin{array}{l}\text { All individual COPC concentrations } \\
\text { are below the direct exposure criteria. }\end{array}$ & Yes \\
\hline \multirow[t]{4}{*}{$\begin{array}{l}\text { Risk Requirements - } \\
\text { Nonradionuclides }\end{array}$} & $\begin{array}{l}\text { Attain a hazard quotient of }<1 \\
\text { for all individual } \\
\text { noncarcinogens. }\end{array}$ & $\begin{array}{l}\text { All individual hazard quotients are } \\
\text { less than } 1 .\end{array}$ & \multirow{4}{*}{ Yes } \\
\hline & $\begin{array}{l}\text { Attain a cumulative hazard } \\
\text { quotient of }<1 \text { for } \\
\text { noncarcinogens. }\end{array}$ & $\begin{array}{l}\text { The cumulative hazard quotient } \\
\left(6.6 \times 10^{-2}\right) \text { is less than } 1 \text {. }\end{array}$ & \\
\hline & $\begin{array}{l}\text { Attain an excess cancer risk of } \\
<1 \times 10^{-6} \text { for individual } \\
\text { carcinogens. }\end{array}$ & $\begin{array}{l}\text { The individual excess cancer risk for } \\
\text { carcinogens are less than } 1 \times 10^{-6} \text {. }\end{array}$ & \\
\hline & $\begin{array}{l}\text { Attain a cumulative excess } \\
\text { cancer risk of }<1 \times 10^{-5} \text { for } \\
\text { carcinogens. }\end{array}$ & $\begin{array}{l}\text { The total excess cancer risk } \\
\left(1.3 \times 10^{-9}\right) \text { is less than } 1 \times 10^{-5} \text {. }\end{array}$ & \\
\hline \multirow[t]{4}{*}{$\begin{array}{l}\text { Groundwater/River } \\
\text { Protection - } \\
\text { Radionuclides }\end{array}$} & $\begin{array}{l}\text { Attain single-COPC } \\
\text { groundwater and river protection } \\
\text { RAGs. }\end{array}$ & $\begin{array}{l}\text { The detected radionuclides } \\
\text { (americium-241 and } \\
\text { plutonium-239/240) are not predicted } \\
\text { to reach groundwater within a } \\
\text { 1,000-year assessment period based on } \\
\text { RESRAD modeling. Therefore, all } \\
\text { groundwater and river protection } \\
\text { RAGs have been attained. }\end{array}$ & \multirow{4}{*}{ Yes } \\
\hline & $\begin{array}{l}\text { Attain national primary drinking } \\
\text { water standards: } 4 \mathrm{mrem} / \mathrm{yr} \\
\text { (beta/gamma) dose rate to target } \\
\text { receptor/organs. }\end{array}$ & $\begin{array}{l}\text { No beta-/gamma-emitting } \\
\text { radionuclides are predicted to reach } \\
\text { groundwater within } 1,000 \text { years; } \\
\text { therefore, the drinking water standard } \\
\text { RAGs have been attained. }\end{array}$ & \\
\hline & $\begin{array}{l}\text { Meet drinking water standards } \\
\text { for alpha emitters: the most } \\
\text { stringent of } 15 \mathrm{pCi} / \mathrm{L} \text { MCL or } \\
1 / 25 \text { th of the derived } \\
\text { concentration guides from DOE } \\
\text { Order } 5400.5 .\end{array}$ & $\begin{array}{l}\text { The detected radionuclides } \\
\text { (americium-241 and } \\
\text { plutonium-239/240) are not predicted } \\
\text { to reach groundwater within a } \\
\text { 1,000-year assessment period based on } \\
\text { RESRAD modeling. Therefore, the } \\
\text { drinking water standards for alpha } \\
\text { emitters have been attained. }\end{array}$ & \\
\hline & $\begin{array}{l}\text { Meet total uranium standard of } \\
21.2 \mathrm{pCi} / \mathrm{L} .\end{array}$ & $\begin{array}{l}\text { There were no detected uranium } \\
\text { concentrations. }\end{array}$ & \\
\hline
\end{tabular}


Table ES-1. Summary of Contaminants of Potential Concern for the 600-111 and UPR-600-16 Sites.

\begin{tabular}{|l|l|l|l|}
\hline \multicolumn{1}{|c|}{$\begin{array}{c}\text { Regulatory } \\
\text { Requirement }\end{array}$} & \multicolumn{1}{|c|}{ Remedial Action Goals } & \multicolumn{1}{c|}{ Results } & $\begin{array}{c}\text { Remedial Action } \\
\text { Objectives } \\
\text { Attained? }\end{array}$ \\
\hline $\begin{array}{l}\text { Groundwater/River } \\
\text { Protection - } \\
\text { Nonradionuclides }\end{array}$ & $\begin{array}{l}\text { Attain individual } \\
\text { nonradionuclide groundwater } \\
\text { and river cleanup requirements. }\end{array}$ & $\begin{array}{l}\text { Residual concentrations of barium, } \\
\text { copper, lead, nickel, silver, and zinc } \\
\text { exceeded the soil RAG for the } \\
\text { protection of groundwater and/or the } \\
\text { Columbia River. However, RESRAD } \\
\text { modeling predicts that these } \\
\text { constituents will not migrate to } \\
\text { groundwater (and thus the Columbia } \\
\text { River) at concentrations exceeding } \\
\text { groundwater or river criteria within } \\
\text { T,000 years. Therefore, residual } \\
\text { concentrations achieve the remedial } \\
\text { action objectives for groundwater and } \\
\text { river protection. }\end{array}$ & Yes \\
\hline
\end{tabular}

a "National Primary Drinking Water Regulations" (40 Code of Federal Regulations 141).

${ }^{\mathrm{b}}$ Radiation Protection of the Public and the Environment (DOE Order 5400.5).

${ }^{c}$ Based on the isotopic distribution of uranium in the 100 Areas, the $30 \mu \mathrm{g} / \mathrm{L} \mathrm{MCL}$ corresponds to $21.2 \mathrm{pCi} / \mathrm{L}$. Concentration-toactivity calculations are documented in Calculation of Total Uranium Activity Corresponding to a Maximum Contaminant Level for Total Uranium of 30 Micrograms per Liter in Groundwater (BHI 2001).

d Based on the 100 Area Analogous Sites RESRAD Calculations (BHI 2005), these constituents are not expected to migrate more than $2 \mathrm{~m}(6.6 \mathrm{ft})$ vertically in 1,000 years (based on the lowest soil-partitioning coefficient [copper] of $22 \mathrm{~mL} / \mathrm{g}$ ). The vadose zone underlying the remediation footprint is approximately $5.8 \mathrm{~m}(19.0 \mathrm{ft})$ thick.

$\mathrm{COPC}=$ contaminant of potential concern

MCL = maximum contaminant level

RAG = remedial action goal

RESRAD $=$ RESidual RADioactivity (dose model) 


\section{REMAINING SITES VERIFICATION PACKAGE FOR THE 600-111, P-11 CRITICAL MASS LABORATORY CRIB, AND UPR-600-16, FIRE AND CONTAMINATION SPREAD WASTE SITES}

\section{STATEMENT OF PROTECTIVENESS}

This report demonstrates that the 600-111, P-11 Critical Mass Laboratory Crib, and UPR-600-16, Fire and Contamination Spread waste sites meet the objectives for interim closure as established in the Remedial Design Report/Remedial Action Work Plan for the 100 Area (RDR/RAWP) (DOE-RL 2005b) and the Interim Action Record of Decision for the 100-BC-1, 100-BC-2, 100-DR-1, 100-DR-2, 100-FR-1, 100-FR-2, 100-HR-1, 100-HR-2, 100-KR-1, 100-KR-2, 100-IU-2, 100-IU-6, and 200-CW-3 Operable Units (Remaining Sites Record of Decision [ROD]) (EPA 1999). These results show that residual soil contaminant concentrations support future land uses that can be represented (or bounded) by a rural-residential scenario. The results also demonstrate that residual concentrations support unrestricted future use of shallow zone soil (i.e., surface to $4.6 \mathrm{~m}$ [15 ft]), and are protective of groundwater and the Columbia River.

A comparison against ecological risk screening levels has been made for the site contaminants of potential concern (COPCs) and other constituents. Screening levels were exceeded for antimony, arsenic, barium, boron, copper, lead, manganese, mercury, vanadium, and zinc. Exceedance of screening values does not necessarily indicate the existence of risk to ecological receptors. It is believed that the presence of these constituents does not pose a risk to ecological receptors because concentrations of antimony, arsenic, manganese, mercury, and vanadium are below site background levels, and barium, boron, copper, and mercury concentrations are consistent with those seen elsewhere at the Hanford Site (no established background value is available for boron). Lead and zinc present at concentrations exceeding background were detected in a single worst-case focused sample of burnt debris and will be evaluated in the context of additional lines of evidence for ecological effects as part of the final closeout for this site. The site does not have a deep zone or residual contaminant concentrations that would require any institutional controls.

\section{GENERAL SITE INFORMATION AND BACKGROUND}

The 600-111 and UPR-600-16 waste sites are located approximately $4.8 \mathrm{~km}(3 \mathrm{mi})$ southsoutheast of the 100-F Area and $0.5 \mathrm{~km}(0.3 \mathrm{mi})$ west of Route 2 North. Figure 1 is a map of the location of these two waste sites. The P-11 Critical Mass Laboratory and Crib, also referred to as the P-11 Facility, included the 120 Experimental Building, 123 Control Building (including septic system), and P-11 Crib, and is collectively listed in the Waste Information Data System (WIDS) as the 600-111 waste site. The UPR-600-16 waste site (WIDS) is an unplanned release of contamination associated with a fire at the 120 Building (600-111) and spread of contamination by water used to extinguish the fire. 
Figure 1. Map of 600-111 and UPR-600-16 Sites.

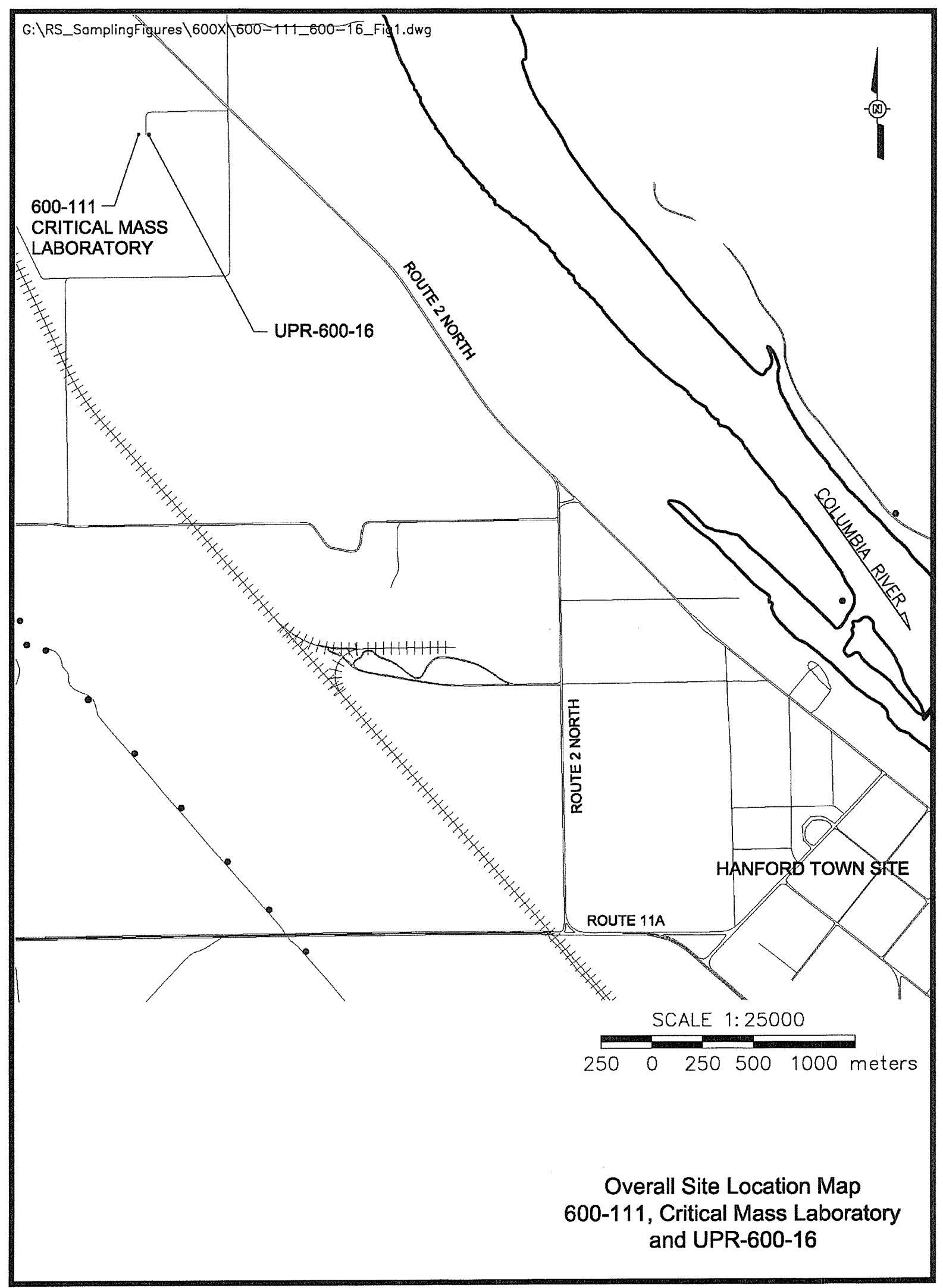


The P-11 Facility was constructed in 1949 and was used as a laboratory for plutonium criticality studies. In November 1951, a criticality resulted in extensive plutonium contamination inside the laboratory building (120 Experimental Building). Activities in the laboratory were suspended to conduct decontamination work. On December 4, 1951, decontamination efforts were in the final stages when a spontaneous ignition of decontamination materials caused a fire that gutted the entire building. Plutonium contamination was spread by the fire and was also washed into the surrounding soil by the water used to extinguish the fire (UPR-600-16). The area was stabilized with clean soil and gravel to prevent wind from spreading the contamination further.

The 120 Experimental Building and its crib were removed in 1974, and the area was released from radiological posting (WIDS). Additional discussion of the history and use of each building and the crib, including the criticality excursion and previous remediation activities, are provided in the confirmatory sampling work instruction (BHI 2004d) and in the P-11 Facility Cleanup Summary Report (ARH 1974). Figure 2 is a photograph of the P-11 Facility prior to the fire.

\section{Figure 2. P-11 Facility Looking Southwest (1949).}

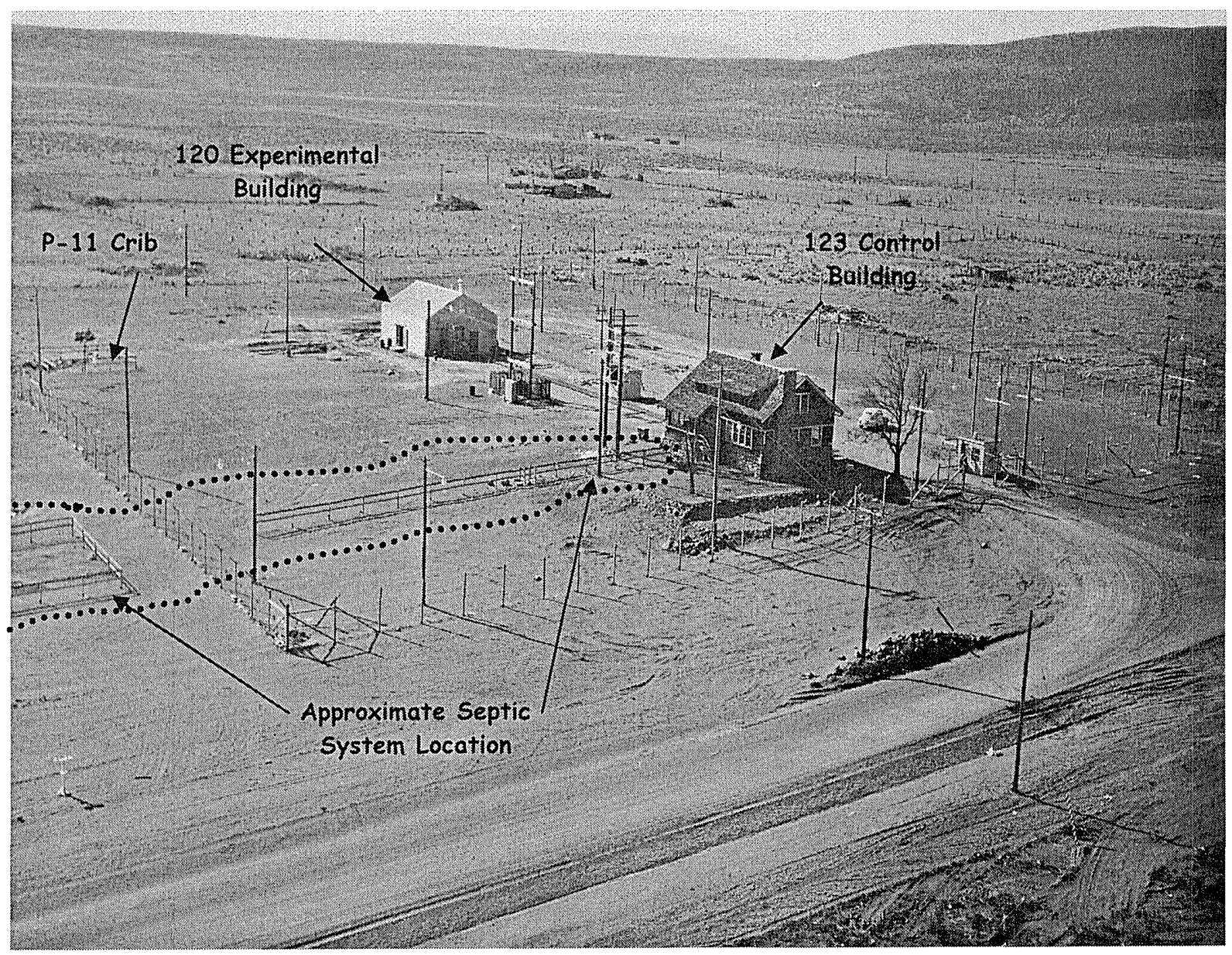




\section{CONFIRMATORY SAMPLING ACTIVITIES}

\section{Site Walkdown}

The geophysical survey team performed a walkdown and geophysical surveys of the 600-111 site in late February 2004 and early March 2004 (BHI 2004c). The results of the walkdown and the geophysical surveys were used to develop the sampling design described in the work instruction for confirmatory sampling (BHI 2004d).

\section{Contaminants of Potential Concern}

The Remaining Sites ROD (EPA 1999) and the RDR/RAWP (DOE-RL 2005b) identify the COPCs as "undetermined radionuclides." Review of the historical information and process knowledge during planning for confirmatory sampling resulted in the following list of COPCs: isotopic plutonium, americium-241, gamma-emitting radionuclides, polychlorinated biphenyls (PCBs), inductively coupled plasma (ICP) metals, mercury, and semivolatile organic compounds (SVOCs). Although asbestos was a COPC, it was only sampled if suspect asbestos material was observed during sampling activities. Volatile organic compounds (VOCs) were not COPCs; however, field screening using an organic vapor meter was performed during excavation. From the work instruction (BHI 2004d), if field-detectable VOCs were found, volatile organic analysis would be added to the sample analyses. During the excavation and sampling activities, the organic vapor meter did not indicate the presence of VOCs.

\section{Confirmatory Sampling Design}

The confirmatory sampling design was developed using the requirements specified in the Sampling and Analysis Plan for the 100 Area Remaining Sites (DOE-RL 2000). The objectives of the confirmatory sampling were to accomplish the following:

1. Collect data to evaluate the adequacy of the remediation performed in 1974.

2. Determine if residual contamination exceeding cleanup criteria is present in the surface soil at the site that might be related to the spread of contamination associated with the 120 Experimental Building fire and UPR-600-16.

3. Collect data to assess protectiveness of subsurface residual radiological and chemical contamination.

To achieve these objectives, the site was stratified into seven areas shown in Figure 3 for evaluation and sample collection:

- Area 1: Former 120 Experimental Building location

- Area 2: Former P-11 Crib location

- Area 3: Former 123 Control Building location

- Area 4: Geophysical anomaly

- Area 5: Septic Drain Field 
Figure 3. Confirmatory Sampling Locations.

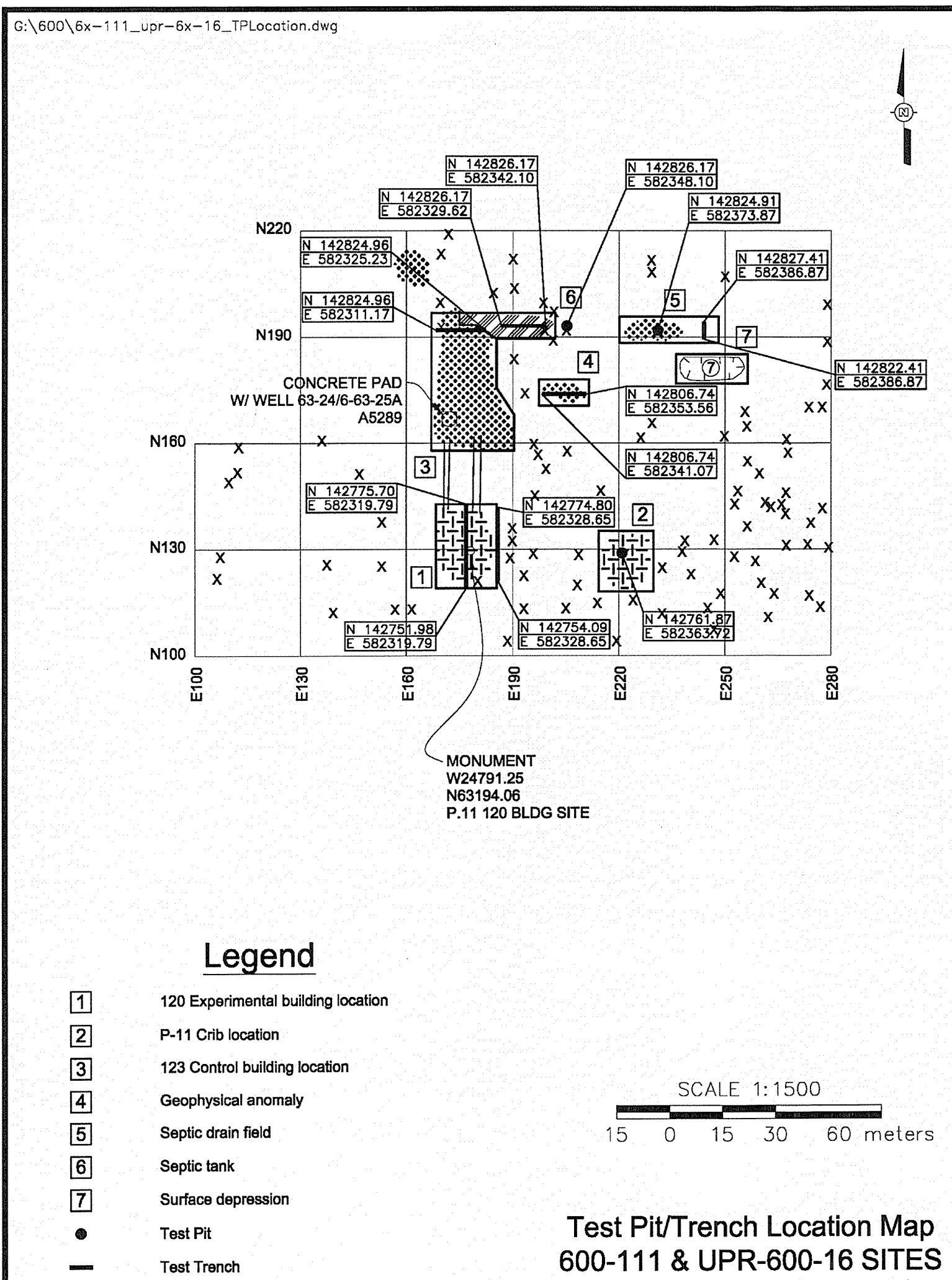

Note: 1. Locations of physical features are approximate. 
- Area 6: Septic Tank

- Area 7: Surface Depression.

The identification of the above sample areas is based on evidence encountered during confirmatory sampling and differs from that based on historical information presented in the work instruction (BHI 2004d). With the exception of Area 7, test trenches/pits were excavated at each location with focused sampling and laboratory analyses performed as specified in the confirmatory sampling work instruction (BHI 2004d). The Area 7 surface depression was initially thought to be the location of the septic drain field; however, the drain field was located at Area 5.

In addition, an intensive radiological surface soil survey of the entire footprint of the site was preformed using a Field Instrument for Detection of Low-Energy Radiation (FIDLER). The survey was performed on a grid to achieve a minimum of $90 \%$ coverage of the surface soil. A FIDLER detector was used because it is sensitive to the detection of the low-energy gamma radiation associated with americium-241, a daughter isotope of plutonium-241. The results of the FIDLER survey were used to determine if any areas of elevated residual radiological contamination could be identified for focused soil sampling of the surface soil.

\section{Confirmatory Sampling Results}

All test pits/trenches were excavated and sampled in late April 2004 through early May 2004 as specified in the sampling work instruction (BHI 2004d). During excavation, field monitoring for VOCs was performed and no constituents were detected. In addition, FIDLER radiological surveys were performed during excavation and no detectable radiological contamination above background was found. Observations recorded in field logbooks (BHI 2003, 2004b) and analytical results (Appendix A) from confirmatory sampling at each location and from the surface soil radiological survey were evaluated and are summarized below:

- Area 1-120 Experimental Building Location: A trench was excavated in Area 1 on May 5, 2004, beginning at the south side of the building and proceeding to the north side. The south section of foundation stem wall $(20 \mathrm{~cm}$ [8 in.] thick) was found intact. Concrete rubble, some fiberglass insulation, rubber hose, metal wire, and electrical wire were found during excavation, with native caliche encountered at a depth of about $1.2 \mathrm{~m}(4 \mathrm{ft})$ below grade. The north wall of the building was unearthed about $10 \mathrm{~m}(33 \mathrm{ft})$ from the south wall. The excavated spoils and debris were surveyed for radiological contamination using a FIDLER, and no field detectable contamination was found. A sample (J01F70) of the native soil collected from along the trench bottom was submitted for laboratory analysis. The trench was then backfilled.

A second trench along the east side of the building was excavated to find the location where the drain line exited the building to the crib and verify that the line to the crib was removed in 1974. The excavation exposed the foundation wall on the east side of the

120 Experimental Building. The excavation proceeded to a depth of $2.1 \mathrm{~m}(7 \mathrm{ft})$ below grade and did not locate a pipeline. The excavation was then backfilled.

- Area 2 - P-11 Crib Location: The crib location was excavated beginning on May 6, 2004, to

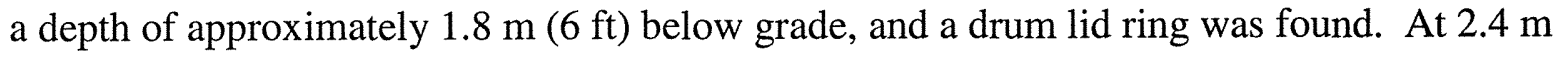


(8-ft) depth two concrete monoliths, one measuring $22.9 \mathrm{~cm}$ by $0.9 \mathrm{~m}$ by $2.4 \mathrm{~m}$ ( 9 in. by $3 \mathrm{ft}$ by $8 \mathrm{ft}$ ) and one measuring $22.9 \mathrm{~cm}$ by $0.9 \mathrm{~m}$ by $2.1 \mathrm{~m}$ ( 9 in. by $3 \mathrm{ft}$ by $7 \mathrm{ft}$ ), were unearthed. A portion of what appeared to be a laboratory cart was also found. The excavation continued on May 10, 2004, and six concrete beams each measuring $20.3 \mathrm{~cm}$ by $20.3 \mathrm{~cm}$ by $2.4 \mathrm{~m}$ ( $8 \mathrm{in}$. by 8 in. by $8 \mathrm{ft}$ ) were unearthed. Field radiological surveys of excavated soil and debris did not detect any radiological contamination. The excavation proceeded to a depth of $3.7 \mathrm{~m}$ (12 ft) where native soil was first encountered. A soil sample (J01F71) and a duplicate soil sample (J01F72) were collected at this depth.

- Area 3-123 Control Building Location: The trench location was moved approximately $18 \mathrm{~m}(59 \mathrm{ft}$ ) north of the planned location at $\mathrm{N} 142804.17 / \mathrm{E} 582314.69$ based on reevaluation of the construction drawings during excavation of Area 4. During excavation of the trench

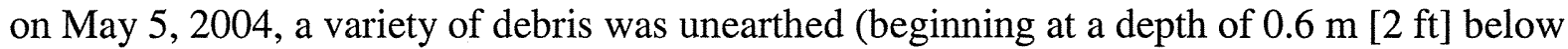
grade) including brick fragments, concrete aggregate, pipe, hog wire, pipe manifold, several pieces of asphalt, and burnt debris. The basement floor was encountered at a depth of $1.2 \mathrm{~m}$ (4 ft) below grade. Burnt debris was found on the floor. A $1.4 \mathrm{~m}(4.5-\mathrm{ft})$ length of $5 \mathrm{~cm}$ (2-in.-) diameter pipe was found, of which an approximate $45.7 \mathrm{~cm}$ (18-in.) portion was painted orange. Insufficient paint was available to collect a sample. The trench was excavated until the outside east end of the building was found at a depth of approximately $1.1 \mathrm{~m}$ (3.5 ft). A sample (J01F85) consisting of burnt debris, wood fragments, sand, concrete sand, and rusty-colored ash was collected from the basement floor.

- Area 4-Geophysical Anomaly: From the geophysical survey, Area 4 was identified as an anomaly and was initially thought to be a septic tank or the location of a former septic tank. A trench was excavated on April 29, 2004, at this location and a native caliche layer was encountered at approximately $0.8 \mathrm{~m}(2.5 \mathrm{ft})$ below ground surface, with no evidence of contaminated soil, debris, or a septic tank. No sampling was performed in Area 4 because no septic tank, debris, or suspect contaminated soil was found. The geophysical anomaly was likely associated with the caliche.

- Area 5 - Septic Drain Field: A test pit was excavated in Area 5 on April 29, 2004. During the excavation a 0.9 to $1.2 \mathrm{~m}$ (3- to 4-ft-) wide concrete pipe encasement was encountered. Review of historical construction drawings indicate that the pipe encasement provided crush protection from heavy equipment for the pipeline running from the septic tank to the septic drain field. A trench was excavated east of Area 5 and north of Area 7 to locate the septic drain field. A north-east-trending $15 \mathrm{~cm}$ (6-in.-) outer diameter clay pipe, believed to be a lateral, was encountered at a depth of $0.9 \mathrm{~m}(3 \mathrm{ft})$. Sediment consisting of alternating $0.41 \mathrm{~cm}(1 / 16$-in.-) thick layers of silt and clay collected from the bottom $5 \mathrm{~cm}(2 \mathrm{in}$.) of the pipe was sampled (J01F84). The excavation was backfilled after sampling was completed.

- Area 6 - Septic Tank and Influent Piping: A trench was excavated in Area 6 on April 29, 2004. During excavation of the trench, concrete rubble, gravel, tar paper, a $7.6 \mathrm{~cm}$ (3-in.-) diameter cast iron pipe, and a $7.6 \mathrm{~cm}$ (3-in.-) diameter vitrified clay pipe were found, indicating that Area 6 is the likely location of the septic system piping. The tar paper was sampled for analysis of suspect asbestos (J01C01). The trench $(1.8 \mathrm{~m}$ wide by $6 \mathrm{~m}$ long by $1.8 \mathrm{~m}$ deep [ $6 \mathrm{ft}$ wide by $20 \mathrm{ft}$ long by $6 \mathrm{ft}$ deep]) was then backfilled. A test pit was

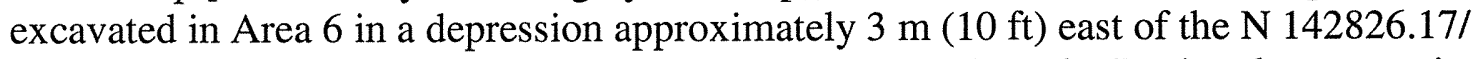
E 582342.10 surveyed location to attempt to find the septic tank. During the excavation 
concrete rubble, a $7.6 \mathrm{~cm}$ (3-in.) cast iron pipe, some fire brick, and a $10 \mathrm{~cm}$ (4-in.) vitrified clay pipe that trended toward the septic drain field were unearthed. The excavation continued and located a $1.2 \mathrm{~m}$ (4-ft-) high by $1.8 \mathrm{~m}$ (6-fí-) diameter metal tank. The bottom of the tank was at a depth of approximately $2 \mathrm{~m}(7 \mathrm{ft})$. The tank was brought to the surface for inspection and sample collection. The tank was filled with soil and gravel. A sample (J01F83) was collected from a $25 \mathrm{~cm}$ (10-in.) layer at the bottom of the tank near the sheet metal wall. The sample contained burnt wood and was observed to be rusty, reddish brown silty sand. The metal debris was placed back into the excavation and backfilled with the spoils pile (soil) after sampling was completed.

- Area 7 - Assumed Septic Drain Field: During planning, Area 7 was initially believed to be the location of the septic drain field because of a surface depression observed at the site. However, during field excavation of Area 6 that unearthed the septic tank, it was decided to excavate the geophysical anomaly (Area 5) directly east of Area 6 at which time the septic drain line was encountered. Further excavation east of Area 5 located the septic drain field. Therefore, no excavation of Area 7 was performed because the septic drain field was found directly east of Area 5 and no geophysical anomalies were identified in Area 7.

- Radiological Surface Soil Survey: An intensive radiological surface soil survey of the entire footprint of the site was performed May 26 through June 2, 2004, using a FIDLER. The survey was performed on a grid over an area of $7,414 \mathrm{~m}^{2}\left(79,803 \mathrm{ft}^{2}\right)$ to achieve a minimum of $90 \%$ coverage of the surface soil. Approximately 58,500 measurements were recorded by the instrumentation. The results of the FIDLER survey are shown in Figure 4. Only 10 of the measurements were greater than background activity; however, they were still less than twice background. The coordinates for the location of the most elevated detectable reading were then used to find the location in the field. The survey team inspected the location and found a large boulder at the surface. Direct readings of the boulder and the soil below the boulder and smears of the boulder itself revealed that the activity was related to natural radioactivity associated with the mineralogical composition of the boulder and not due to contamination from Hanford Site operations or the criticality excursion. This information was discussed with the U.S. Environmental Protection Agency (EPA) Project Manager, and it was decided that surface soil samples were not necessary because the few detectable measurements were well below background and the most elevated measurement was due to natural radioactivity.

Table 1 provides a summary of the sampling and laboratory analysis that was performed for the 600-111 site. 


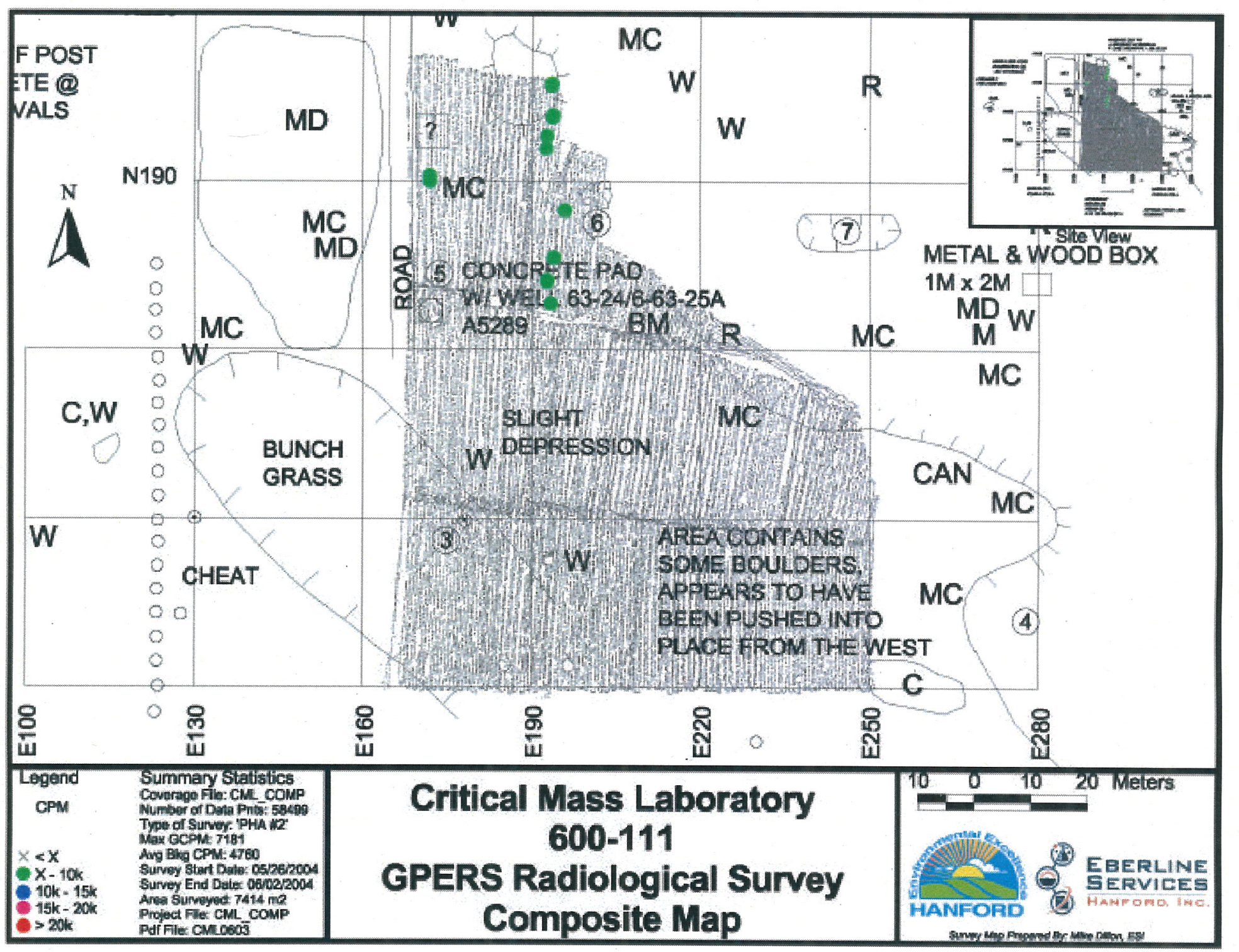


Table 1. Confirmatory Sampling Summary.

\begin{tabular}{|c|c|c|c|c|}
\hline $\begin{array}{l}\text { Sample } \\
\text { Location }\end{array}$ & $\begin{array}{l}\text { HEIS } \\
\text { Sample } \\
\text { Number }\end{array}$ & Sample Media & $\begin{array}{l}\text { Depth } \\
\text { (m bgs) }\end{array}$ & Sample Analysis ${ }^{\mathrm{a}}$ \\
\hline $\begin{array}{l}120 \text { Building } \\
\text { (Area 1) }\end{array}$ & J01F70 & Native soil & 1.22 & $\begin{array}{l}\text { Isotopic plutonium, Am-241, GEA, } \\
\text { PCB, ICP metals, mercury, SVOA }\end{array}$ \\
\hline $\begin{array}{c}\text { Crib } \\
\text { (Area 2) }\end{array}$ & J01F71 & $\begin{array}{l}\text { Native soil below } \\
\text { backfill }\end{array}$ & 3.65 & $\begin{array}{l}\text { Isotopic plutonium, Am-241, GEA, } \\
\text { PCB, ICP metals, mercury, SVOA }\end{array}$ \\
\hline $\begin{array}{l}123 \text { Control } \\
\text { Building } \\
\text { (Area 3) }\end{array}$ & J01F85 & $\begin{array}{l}\text { Burnt debris, wood } \\
\text { fragments, sand, } \\
\text { concrete sand, ash }\end{array}$ & 1.22 & $\begin{array}{l}\text { Isotopic plutonium, Am-241, GEA, } \\
\text { PCB, ICP metals, mercury, SVOA }\end{array}$ \\
\hline $\begin{array}{l}\text { Geophysical } \\
\text { anomaly } \\
\text { (Area 4) }\end{array}$ & \multicolumn{4}{|c|}{$\begin{array}{l}\text { This anomaly was believed to be the location of the septic tank; however, excavation revealed } \\
\text { the anomaly was the result of a native caliche layer at about } 0.76 \mathrm{~m}(2.5 \mathrm{ft}) \text { below grade. } \\
\text { Therefore, no sampling was performed. }\end{array}$} \\
\hline $\begin{array}{l}\text { Drain field (east } \\
\text { of Area 5) }\end{array}$ & J01F84 & Sewer pipe contents & 0.91 & $\begin{array}{l}\text { Isotopic plutonium, Am-241, GEA, } \\
\text { PCB, ICP metals, mercury, SVOA, } \\
\text { TCLP SVOA, TCLP metals }\end{array}$ \\
\hline \multirow{2}{*}{$\begin{array}{l}\text { Septic tank } \\
\text { (Area 6) }\end{array}$} & J01F83 & Septic tank contents & 2.13 & $\begin{array}{l}\text { Isotopic plutonium, Am-241, GEA, } \\
\text { PCB, ICP metals, mercury, SVOA }\end{array}$ \\
\hline & $\mathrm{J} 01 \mathrm{C} 01$ & Tar paper & $0-1.8$ & Asbestos \\
\hline $\begin{array}{l}\text { Surface } \\
\text { depression } \\
\text { (Area 7) }\end{array}$ & \multicolumn{4}{|c|}{$\begin{array}{l}\text { This surface depression was originally believed to be the location of the septic drain field; } \\
\text { however, excavation east of Area } 5 \text { located the drain field, and therefore no further evaluation in } \\
\text { this area was necessary. }\end{array}$} \\
\hline $\begin{array}{l}\text { Equipment } \\
\text { blank }\end{array}$ & J01F82 & Silica sand & N/A & $\begin{array}{l}\text { Isotopic plutonium, Am-241, GEA, } \\
\text { PCB, ICP metals, mercury, SVOA }\end{array}$ \\
\hline $\begin{array}{l}\text { Duplicate } \\
\text { (crib) }\end{array}$ & J01F72 & $\begin{array}{l}\text { Native soil below } \\
\text { backfill }\end{array}$ & 3.65 & $\begin{array}{l}\text { Isotopic plutonium, Am-241, GEA, } \\
\text { PCB, ICP metals, mercury, SVOA }\end{array}$ \\
\hline
\end{tabular}

${ }^{\mathrm{a}}$ Volatile organic compounds are not COPCs. Field screening using an organic vapor meter was performed during excavation, and no detectable volatile organic compounds were found.

bgs $=$ below ground surface

COPC $=$ contaminant of potential concern

$\mathrm{GEA}=$ gamma energy analysis

HEIS = Hanford Environmental Information System

ICP = inductively coupled plasma

$\mathrm{N} / \mathrm{A}=$ not applicable

$\mathrm{PCB}=$ polychlorinated biphenyl

SVOA $=$ semivolatile organic analysis

TCLP $=$ toxic characteristic leachate procedure

\section{CONFIRMATORY SAMPLING DATA EVALUATION}

The confirmatory samples were analyzed by offsite contract laboratories using EPA-approved analytical methods. After sampling was completed, all of the laboratory data from one sampling data group were validated to level $\mathrm{C}$ in accordance with BHI-EE-01, Environmental Investigation Procedures. A data quality assessment (DQA) review was performed to compare the sampling approach and resulting analytical data with the sampling and data quality requirements specified by the project objectives and performance specifications. The results of this review are reported in Appendix B. The sample results are stored in the Environmental 
Restoration (ENRE) project-specific database prior to archiving in the Hanford Environmental Information System (HEIS) and are summarized in the data summary tables (Appendix A).

\section{Confirmatory Sampling Results}

Process knowledge, historical information, field observations, and radiological survey instruments were used to identify locations with the greatest potential for residual contamination. In accordance with the focused sampling approach and Washington Administrative Code (WAC) 173-340-740(7)(d)(iii), direct comparison of these focused sample results with the remedial action goals (RAGs) is an acceptable method to evaluate compliance with cleanup objectives for the 600-111 site.

Tables 2 through 6 provide the detected sample results for each of the areas identified for the 600-111 site (BHI 2004d). Cleanup levels from the RDR/RAWP (DOE-RL 2005b) are also included in Tables 2 through 6. Calculated cleanup levels for aluminum, calcium, iron, magnesium, potassium, silicon, and sodium are not presented in the Cleanup Levels and Risk Calculations under the Model Toxics Control Act Cleanup Regulation (CLARC table) under WAC 173-340-740(3) and; thus, are not considered COPCs. However, data results for these constituents are presented in Appendix A.

Contaminants that were not detected by laboratory analyses are excluded from the tables. Several radionuclides had analytical results above the minimum detectable activity (Appendix A) but were not included in further evaluations. Potassium- 40 occurs as part of natural background and is not included in evaluation of risk above background. Maximum activities of radium-226 and thorium-232 are below Hanford Site background and are not included in further evaluations. Radium-228 and thorium-228 are daughter products of thorium-232 and will be in secular equilibrium with their parent isotope and are, therefore, not included in evaluation of risk above background. Complete sample results are provided in Appendix A.

Maximum detected sample results were directly compared to the cleanup levels; therefore, the three-part test discussed in WAC 173-340-740(7)(e) was not performed. The sample results for each area (P-11 Crib location, 120 Experimental Building location, 123 Control Building location, septic tank, and septic drain field) were individually used to evaluate each area and determine if that area independently meets the RAGs. This evaluation for radionuclide constituents and nonradionuclide constituents is discussed in the following sections.

The sample collected from the septic drain field (J01F84) exhibited concentrations of lead, barium, cadmium, and mercury that exceed the criteria for toxic characteristic waste as specified in WAC 173-303-090(8)(c); therefore, the toxic characteristic leachate procedure (TCLP) metals analysis was performed to support waste disposition for removal of the septic system. In addition, TCLP semivolatile analysis was requested for this sample because the semivolatile organic analysis (SVOA) detection limits were high due to sample dilution associated with matrix interference. The results of the TCLP analysis (Appendix A) indicated that the septic system would not require management or disposal as a dangerous waste. 
Table 2. Comparison of 120 Experimental Building (Area 1) Sample Results to Action Levels.

\begin{tabular}{|c|c|c|c|c|c|c|}
\hline \multirow[b]{2}{*}{ COPC } & \multirow[b]{2}{*}{$\begin{array}{c}\text { Maximum Result } \\
\qquad(\mathrm{pCi} / \mathrm{g})\end{array}$} & \multicolumn{3}{|c|}{ Generic Site Lookup Values $(\mathrm{pCi} / \mathrm{g})^{\mathrm{a}}$} & \multirow[b]{2}{*}{$\begin{array}{l}\text { Does the } \\
\text { Maximum } \\
\text { Result Exceed } \\
\text { RAGs? }\end{array}$} & \multirow[b]{2}{*}{$\begin{array}{c}\text { Do the Maximum } \\
\text { Results Pass } \\
\text { RESRAD } \\
\text { Modeling? }\end{array}$} \\
\hline & & $\begin{array}{c}\text { Direct } \\
\text { Exposure }\end{array}$ & $\begin{array}{l}\text { Soil Standard } \\
\text { for } \\
\text { Groundwater } \\
\text { Protection }\end{array}$ & $\begin{array}{c}\text { Soil } \\
\text { Standard } \\
\text { for River } \\
\text { Protection }\end{array}$ & & \\
\hline \multicolumn{7}{|c|}{ Radionuclides (pCi/g) } \\
\hline COPC & $\begin{array}{c}\text { Maximum Result } \\
\text { (mg/kg) }\end{array}$ & $\begin{array}{c}\text { Direct } \\
\text { Exposure }\end{array}$ & $\begin{array}{c}\text { Soil Standard } \\
\text { for } \\
\text { Groundwater } \\
\text { Protection }\end{array}$ & $\begin{array}{c}\text { Soil } \\
\text { Standard } \\
\text { for River } \\
\text { Protection }\end{array}$ & $\begin{array}{c}\text { Does the } \\
\text { Maximum } \\
\text { Result Exceed } \\
\text { RAG? }\end{array}$ & $\begin{array}{c}\text { Does RESRAD } \\
\text { Indicate GW and } \\
\text { River } \\
\text { Protectiveness? }\end{array}$ \\
\hline \multicolumn{7}{|c|}{ Nonradionuclides (mg/kg) } \\
\hline Beryllium & $0.66(<\mathrm{BG})$ & $10.4^{\mathrm{d}}$ & $1.51^{b}$ & $1.51^{\mathrm{b}}$ & No & -- \\
\hline Boron & 0.95 & 16,000 & 320 & $-\mathrm{e}^{\mathrm{e}}$ & No & -- \\
\hline Cadmium & $0.36(<\mathrm{BG})$ & 13.9 & $0.81^{b}$ & $0.81^{\mathrm{b}}$ & No & - \\
\hline Chromium (total) & $17.9(<\mathrm{BG})$ & 80,000 & $18.5^{b}$ & $18.5^{b}$ & No & -- \\
\hline Cobalt & $9.7(<\mathrm{BG})$ & 1,600 & 32 & $-\mathrm{e}^{\mathrm{e}}$ & No & - \\
\hline Copper & 29.1 & 2,960 & 59.2 & $22.0^{\mathrm{b}}$ & Yes & Yes $^{c}$ \\
\hline Lead & 11.3 & 353 & $10.2^{b}$ & $10.2^{b}$ & Yes & Yes $^{c}$ \\
\hline Manganese & $441(<\mathrm{BG})$ & 11,200 & $512^{b}$ & $512^{b}$ & No & -- \\
\hline Mercury & $0.02(<\mathrm{BG})$ & 24 & $0.33^{b}$ & $0.33^{b}$ & No & -- \\
\hline \multirow{2}{*}{\multicolumn{7}{|c|}{$\begin{array}{l}\text { Where cleanup levels are less than background, cleanup levels default to background (WAC 173-340-700[4][d], 1996). } \\
\text { Based on the } 100 \text { Area Analogous Sites RESRAD Calculations (BHI 2005), residual concentrations are not expected to migrate more } \\
\text { than } 3 \mathrm{~m}(9.8 \mathrm{ft} \text { ) vertically in 1,000 years based on the lowest soil-partitioning coefficient of those contaminants that exceeded the RAG } \\
\text { (copper; } 22 \mathrm{~mL} / \mathrm{g} \text { ). The vadose zone underlying the remediation footprint is approximately } 5.8 \mathrm{~m} \text { (19.0 ft) thick. Therefore, residual } \\
\text { concentrations of these contaminants are predicted to be protective of groundwater and the Columbia River. }\end{array}$}} \\
\hline & & & & & & \\
\hline \multirow{2}{*}{\multicolumn{7}{|c|}{$\begin{array}{l}\text { Carcinogenic cleanup level calculated based on the inhalation exposure pathway (WAC 173-340-750[3], 1996) and an airborne } \\
\text { particulate mass-loading rate of } 0.0001 \mathrm{~g} / \mathrm{m}^{3} \text { (WDOH 1997). } \\
\text { No cleanup level is available from the Cleanup Levels and Risk Calculations (CLARC) database (Ecology 2005) and/or no } \\
\text { bioconcentration factors or ambient water quality criteria values are available to calculate soil cleanup levels protective of the river. }\end{array}$}} \\
\hline & & & & & & \\
\hline \multicolumn{7}{|c|}{$\quad=$ not applicable } \\
\hline & \multicolumn{6}{|c|}{ = background } \\
\hline \multicolumn{7}{|c|}{$=$ contaminant of potential concern } \\
\hline \multicolumn{7}{|c|}{$=$ groundwater $\mathrm{r}$. } \\
\hline \multicolumn{7}{|c|}{$=$ remedial action goal } \\
\hline \multirow{2}{*}{\multicolumn{7}{|c|}{$\begin{array}{l}\text { RESRAD = RESidual RADioactivity (dose model) } \\
\text { WAC = Washington Administrative Code }\end{array}$}} \\
\hline & & $e$ & & & & \\
\hline
\end{tabular}


Table 3. Comparison of Crib (Area 2) Sample Results to Action Levels.

\begin{tabular}{|c|c|c|c|c|c|c|}
\hline \multirow[b]{2}{*}{ COPC } & \multirow[b]{2}{*}{$\underset{(\mathrm{pCi} / \mathrm{g})}{\text { Maximum Result }}$} & \multicolumn{3}{|c|}{ Generic Site Lookup Values (pCi/g) ${ }^{a}$} & \multirow[b]{2}{*}{$\begin{array}{c}\text { Does the } \\
\text { Maximum } \\
\text { Result Exceed } \\
\text { RAGs? }\end{array}$} & \multirow[b]{2}{*}{$\begin{array}{l}\text { Do the Maximum } \\
\text { Results Pass } \\
\text { RESRAD } \\
\text { Modeling? }\end{array}$} \\
\hline & & $\begin{array}{c}\text { Direct } \\
\text { Exposure }\end{array}$ & $\begin{array}{c}\text { Soil Standard } \\
\text { for } \\
\text { Groundwater } \\
\text { Protection }\end{array}$ & \begin{tabular}{|c|} 
Soil \\
Standard \\
for River \\
Protection
\end{tabular} & & \\
\hline \multicolumn{7}{|c|}{ Radionuclides (pCi/g) } \\
\hline Americium-241 & 0.266 & 31.1 & $-{ }^{\mathrm{b}}$ & $--^{b}$ & No & -- \\
\hline Plutonium-239/240 & 0.816 & 33.9 & $-\mathrm{b}^{\mathrm{b}}$ & $-\mathrm{b}^{\mathrm{b}}$ & No & -- \\
\hline \multirow[b]{2}{*}{ COPC } & \multirow[b]{2}{*}{$\underset{(\mathrm{mg} / \mathrm{kg})}{\text { Maximum Result }}$} & \multicolumn{3}{|c|}{ Remedial Action Goals (mg/kg) } & \multirow[b]{2}{*}{$\begin{array}{l}\text { Does the } \\
\text { Maximum } \\
\text { Result Exceed } \\
\text { RAGs? }\end{array}$} & \multirow[b]{2}{*}{$\begin{array}{l}\text { Do the Maximum } \\
\text { Results Pass } \\
\text { RESRAD } \\
\text { Modeling? }\end{array}$} \\
\hline & & $\begin{array}{c}\text { Direct } \\
\text { Exposure }\end{array}$ & $\begin{array}{c}\begin{array}{c}\text { Soil Standard } \\
\text { for }\end{array} \\
\text { Groundwater } \\
\text { Protection }\end{array}$ & \begin{tabular}{|c|} 
Soil \\
Standard \\
for River \\
Protection
\end{tabular} & & \\
\hline \multicolumn{7}{|c|}{ Nonradionuclides (mg/kg) } \\
\hline Arsenic & 8.7 & 20 & 20 & 20 & No & -- \\
\hline Barium & $102(<\mathrm{BG})$ & 5,600 & $132^{\mathrm{c}}$ & 224 & No & -- \\
\hline Beryllium & $0.29(<\mathrm{BG})$ & $10.4^{\mathrm{d}}$ & $1.51^{\mathrm{c}}$ & $1.51^{\mathrm{c}}$ & No & -- \\
\hline Boron & 1.5 & 16,000 & 320 & $--^{\mathrm{e}}$ & No & -- \\
\hline Cadmium & $0.09(<\mathrm{BG})$ & 13.9 & $0.81^{\mathrm{c}}$ & $0.81^{\mathrm{c}}$ & No & -- \\
\hline Chromium (total) & $11.8(<\mathrm{BG})$ & 80,000 & $18.5^{\mathrm{c}}$ & $18.5^{c}$ & No & - \\
\hline Cobalt & $8.1(<\mathrm{BG})$ & 1,600 & 32 & $--^{e}$ & No & - \\
\hline Copper & $16.8(<\mathrm{BG})$ & 2,960 & 59.2 & $22.0^{c}$ & No & -- \\
\hline Lead & 18.6 & 353 & $10.2^{\mathrm{c}}$ & $10.2^{c}$ & Yes & Yes $^{f}$ \\
\hline Manganese & $378(<\mathrm{BG})$ & 11,200 & $512^{c}$ & $512^{c}$ & No & -- \\
\hline Molybdenum & 0.54 & 400 & 8 & $--^{\mathrm{e}}$ & No & -- \\
\hline Nickel & $15.4(<\mathrm{BG})$ & 1,600 & $19.1^{\mathrm{c}}$ & 27.4 & No & -- \\
\hline Selenium & $0.29(<\mathrm{BG})$ & 400 & 5 & 1 & No & -- \\
\hline Vanadium & $58.5(<\mathrm{BG})$ & 560 & $85.1^{\mathrm{c}}$ & $--^{\mathrm{e}}$ & No & - \\
\hline Zinc & $49.2(<\mathrm{BG})$ & 24,000 & 480 & $67.8^{c}$ & No & $\cdots$ \\
\hline
\end{tabular}

${ }^{a}$ Lookup values and RAGs obtained from the Remedial Design Report/Remedial Action Work Plan for the 100 Area (100 Area RDR/RAWP) (DOE-RL 2005b) or calculated per WAC 173-340-720, WAC 173-340-730, and WAC 173-340-740, Method B, 1996, unless otherwise noted.

b The 100 Area RDR/RAWP (DOE-RL 2005b) does not provide soil cleanup levels for this contaminant to be protective of groundwater and the Columbia River. Based on the soil partitioning distribution coefficient for americium-214 and plutonium-239/240 of $200 \mathrm{~mL} / \mathrm{g}$, these contaminants are not predicted to migrate vertically in 1,000 years (BHI 2005). The vadose zone underlying this site is approximately $5.8 \mathrm{~m}(19.0 \mathrm{ft})$ thick. Therefore, residual concentration of this contaminant is predicted to be protective of groundwater and the Columbia River.

${ }^{c}$ Where cleanup levels are less than background, cleanup levels default to background (WAC 173-340-700[4][d], 1996).

d Carcinogenic cleanup level calculated based on the inhalation exposure pathway (WAC 173-340-750[3], 1996) and an airborne particulate mass-loading rate of $0.0001 \mathrm{~g} / \mathrm{m}^{3}$ (WDOH 1997).

${ }^{e}$ No cleanup level is available from the Cleanup Levels and Risk Calculations (CLARC) database (Ecology 2005) and/or no bioconcentration factors or ambient water quality criteria values are available to calculate soil cleanup levels protective of the river.

f Based on the 100 Area Analogous Sites RESRAD Calculations (BHI 2005), residual concentrations are not expected to migrate more

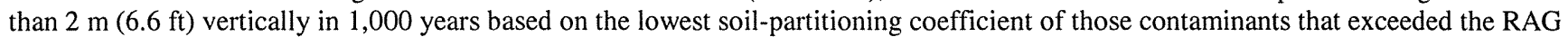
(lead; $30 \mathrm{~mL} / \mathrm{g}$ ). The vadose zone underlying the remediation footprint is approximately $5.8 \mathrm{~m}(19.0 \mathrm{ft})$ thick. Therefore, residual concentrations of these contaminants are predicted to be protective of groundwater and the Columbia River.
-- $\quad=$ not applicable
RAG = remedial action goal
$\mathrm{BG} \quad=$ background
$\mathrm{COPC}=$ contaminant of potential concern
RESRAD $=$ RESidual RADioactivity (dose model)
WAC = Washington Administrative Code 
Table 4. Comparison of 123 Control Building (Area 3) Sample Results to Action Levels.

\begin{tabular}{|c|c|c|c|c|c|c|}
\hline \multirow[b]{2}{*}{ COPC } & \multirow[b]{2}{*}{$\begin{array}{c}\text { Maximum Result } \\
(\mathrm{pCi} / \mathrm{g})\end{array}$} & \multicolumn{3}{|c|}{ Generic Site Lookup Values (pCi/g) ${ }^{\mathrm{a}}$} & \multirow[b]{2}{*}{$\begin{array}{c}\text { Does the } \\
\text { Maximum } \\
\text { Result Exceed } \\
\text { Lookup Value? }\end{array}$} & \multirow[b]{2}{*}{$\begin{array}{c}\text { Does RESRAD } \\
\text { Indicate GW and } \\
\text { River } \\
\text { Protectiveness? }\end{array}$} \\
\hline & & $\begin{array}{c}\text { Direct } \\
\text { Exposure }\end{array}$ & $\begin{array}{c}\begin{array}{c}\text { Soil Standard } \\
\text { for }\end{array} \\
\text { Groundwater } \\
\text { Protection }\end{array}$ & $\begin{array}{c}\text { Soil } \\
\text { Standard } \\
\text { for River } \\
\text { Protection }\end{array}$ & & \\
\hline \multicolumn{7}{|c|}{ Radionuclides (pCi/g) } \\
\hline Cesium-137 & 0.361 & 6.2 & $--^{b}$ & $--^{b}$ & No & -- \\
\hline \multirow[b]{2}{*}{ COPC } & \multirow[b]{2}{*}{$\begin{array}{c}\text { Maximum Result } \\
(\mathrm{mg} / \mathrm{kg})\end{array}$} & \multicolumn{3}{|c|}{ Remedial Action Goals (mg/kg) ${ }^{\mathrm{a}}$} & \multirow{2}{*}{$\begin{array}{l}\text { Does the } \\
\text { Maximum } \\
\text { Result Exceed } \\
\text { RAG? }\end{array}$} & \multirow[b]{2}{*}{$\begin{array}{c}\text { Does RESRAD } \\
\text { Indicate GW and } \\
\text { River } \\
\text { Protectiveness? }\end{array}$} \\
\hline & & $\begin{array}{c}\text { Direct } \\
\text { Exposure }\end{array}$ & $\begin{array}{c}\text { Soil Standard } \\
\text { for } \\
\text { Groundwater } \\
\text { Protection }\end{array}$ & $\begin{array}{c}\text { Soil } \\
\text { Standard } \\
\text { for River } \\
\text { Protection }\end{array}$ & & \\
\hline \multicolumn{7}{|c|}{ Nonradionuclides $(\mathrm{mg} / \mathrm{kg})$} \\
\hline Arsenic & 19.7 & 20 & 20 & 20 & No & -- \\
\hline Barium & $117(<\mathrm{BG})$ & 5,600 & $132^{\mathrm{c}}$ & 224 & No & -- \\
\hline Beryllium & $0.48(<\mathrm{BG})$ & $10.4^{\mathrm{d}}$ & $1.51^{\mathrm{c}}$ & $1.51^{\mathrm{c}}$ & No & - \\
\hline Boron & 2.7 & 7,200 & 144 & $--^{\mathrm{e}}$ & No & -- \\
\hline Cadmium & $0.27(<\mathrm{BG})$ & 13.9 & $0.81^{\mathrm{c}}$ & $0.81^{\mathrm{c}}$ & No & -- \\
\hline Chromium (total) & $11.9(<\mathrm{BG})$ & 80,000 & $18.5^{\mathrm{c}}$ & $18.5^{\mathrm{c}}$ & No & -- \\
\hline Cobalt & $6.8(<\mathrm{BG})$ & 1,600 & 32 & $--^{\mathrm{e}}$ & No & -- \\
\hline Copper & 39.6 & 2,960 & 59.2 & $22.0^{c}$ & Yes & $\mathrm{Yes}^{\mathrm{f}}$ \\
\hline Lead & 142 & 353 & $10.2^{c}$ & $10.2^{\mathrm{c}}$ & Yes & Yes $^{\mathrm{f}}$ \\
\hline Manganese & $353(<\mathrm{BG})$ & 11,200 & $512^{c}$ & $512^{c}$ & No & -- \\
\hline Molybdenum & 0.66 & 400 & 8 & $-{ }^{\mathrm{e}}$ & No & - \\
\hline Nickel & $11(<\mathrm{BG})$ & 1,600 & $19.1^{\mathrm{c}}$ & 27.4 & No & -- \\
\hline \begin{tabular}{|l|} 
Vanadium \\
\end{tabular} & $44.9(<\mathrm{BG})$ & 560 & $85.1^{c}$ & $-^{e}$ & No & -- \\
\hline Zinc & 177 & 24,000 & 480 & $67.8^{c}$ & Yes & $\mathrm{Yes}^{\mathrm{f}}$ \\
\hline Pyrene & 0.0251 & 2,400 & 48 & 192 & No & -- \\
\hline
\end{tabular}

${ }^{a}$ Lookup values and RAGs obtained from the Remedial Design Report/Remedial Action Work Plan for the 100 Area (100 Area RDR/RAWP) (DOE-RL 2005b) or calculated per WAC 173-340-720, WAC 173-340-730, and WAC 173-340-740, Method B, 1996, unless otherwise noted.

${ }^{\mathrm{b}}$ The 100 Area RDR/RAWP (DOE-RL 2005b) does not provide soil cleanup levels for this contaminant to be protective of groundwater and the Columbia River. Based on the soil partitioning distribution coefficient for cesium- $137 \mathrm{of} 50 \mathrm{~mL} / \mathrm{g}$, this contaminants is not predicted to migrate vertically in 1,000 years (BHI 2005). The vadose zone underlying this site is approximately $5.8 \mathrm{~m}(19.0 \mathrm{ft})$ thick. Therefore, residual concentration of this contaminant is predicted to be protective of groundwater and the Columbia River.

${ }^{c}$ Where cleanup levels are less than background, cleanup levels default to background (WAC 173-340-700[4][d], 1996).

${ }^{d}$ Carcinogenic cleanup level calculated based on the inhalation exposure pathway (WAC 173-340-750[3], 1996) and an airborne particulate mass-loading rate of $0.0001 \mathrm{~g} / \mathrm{m}^{3}$ (WDOH 1997).

e No cleanup level is available from the Cleanup Levels and Risk Calculations (CLARC) database (Ecology 2005) and/or no bioconcentration factors or ambient water quality criteria values are available to calculate soil cleanup levels protective of the river.

${ }^{\mathrm{f}}$ Based on the 100 Area Analogous Sites RESRAD Calculations (BHI 2005), residual concentrations are not expected to migrate more than $3 \mathrm{~m}(9.8 \mathrm{ft})$ vertically in 1,000 years based on the lowest soil-partitioning coefficient of those contaminants that exceeded the RAG (copper; $22 \mathrm{~mL} / \mathrm{g}$ ). The vadose zone underlying the remediation footprint is approximately $5.8 \mathrm{~m}$ ( $19.0 \mathrm{ft}$ ) thick. Therefore, residual concentrations of these contaminants are predicted to be protective of groundwater and the Columbia River.

$\begin{array}{llll}- & =\text { not applicable } & \text { RAG } & =\text { remedial action goal } \\ \mathrm{BG} & =\text { background } & \text { RESRAD } & =\text { RESidual RADioactivity (dose model) } \\ \mathrm{COPC} & =\text { contaminant of potential concern } & \text { WAC } & =\text { Washington Administrative Code } \\ \text { GW } & =\text { groundwater } & & \end{array}$

$\mathrm{GW} \quad=$ groundwater 
Table 5. Comparison of Septic Drain Field (Area 5) Sample Results to Action Levels.

\begin{tabular}{|c|c|c|c|c|c|c|}
\hline \multirow[b]{2}{*}{ COPC } & \multirow[b]{2}{*}{$\begin{array}{c}\text { Maximum Result } \\
\quad(\mathbf{p C i} / \mathrm{g})\end{array}$} & \multicolumn{3}{|c|}{ Generic Site Lookup Values (pCi/g) ${ }^{a}$} & \multirow[b]{2}{*}{$\begin{array}{c}\text { Does the } \\
\text { Maximum } \\
\text { Result Exceed } \\
\text { Lookup Value? }\end{array}$} & \multirow[b]{2}{*}{$\begin{array}{c}\text { Does RESRAD } \\
\text { Indicate GW and } \\
\text { River } \\
\text { Protectiveness? }\end{array}$} \\
\hline & & $\begin{array}{c}\text { Direct } \\
\text { Exposure }\end{array}$ & $\begin{array}{c}\begin{array}{c}\text { Soil Standard } \\
\text { for }\end{array} \\
\text { Groundwater } \\
\text { Protection }\end{array}$ & $\begin{array}{c}\text { Soil } \\
\text { Standard } \\
\text { for River } \\
\text { Protection } \\
\end{array}$ & & \\
\hline \multicolumn{7}{|c|}{ Radionuclides (pCi/g) } \\
\hline \multicolumn{7}{|c|}{ No radionuclides detected above the minimum detectable activity or background concentrations. } \\
\hline \multirow[b]{2}{*}{ COPC } & \multirow[b]{2}{*}{$\begin{array}{c}\text { Maximum Result } \\
(\mathrm{mg} / \mathrm{kg})\end{array}$} & \multicolumn{3}{|c|}{ Remedial Action Goals (mg/kg) ${ }^{\mathrm{a}}$} & \multirow[b]{2}{*}{$\begin{array}{l}\text { Does the } \\
\text { Maximum } \\
\text { Result Exceed } \\
\text { RAG? }\end{array}$} & \multirow[b]{2}{*}{$\begin{array}{c}\text { Does RESRAD } \\
\text { Indicate GW and } \\
\text { River } \\
\text { Protectiveness? }\end{array}$} \\
\hline & & $\begin{array}{c}\text { Direct } \\
\text { Exposure }\end{array}$ & $\begin{array}{c}\text { Soil Standard } \\
\text { for } \\
\text { Groundwater } \\
\text { Protection }\end{array}$ & $\begin{array}{c}\text { Soil } \\
\text { Standard } \\
\text { for River } \\
\text { Protection }\end{array}$ & & \\
\hline \multicolumn{7}{|c|}{ Nonradionuclides $(\mathrm{mg} / \mathrm{kg})$} \\
\hline Antimony & $2.0(<\mathrm{BG})$ & 32 & $5^{\mathrm{b}}$ & $5^{\mathrm{b}}$ & No & -- \\
\hline Arsenic & 43.8 & 20 & 20 & 20 & Yes & No \\
\hline Barium & 3,340 & 5,600 & $132^{\mathrm{b}}$ & 224 & Yes & Yes $^{\mathrm{d}}$ \\
\hline Beryllium & $0.45(<\mathrm{BG})$ & $10.4^{\mathrm{e}}$ & $1.51^{\mathrm{b}}$ & $1.51^{\mathrm{b}}$ & No & -- \\
\hline Boron & 4.1 & 16,000 & 320 & $-{ }^{\mathrm{f}}$ & No & -- \\
\hline Cadmium & 20.4 & 13.9 & $0.81^{\mathrm{b}}$ & $0.81^{\mathrm{b}}$ & Yes & $--^{c}$ \\
\hline Chromium, total & 40.2 & 80,000 & $18.5^{\mathrm{b}}$ & $18.5^{\mathrm{b}}$ & Yes & Yes $^{\mathrm{d}}$ \\
\hline Cobalt & $6.9(<\mathrm{BG})$ & 1,600 & 32 & $--^{f}$ & No & -- \\
\hline Copper & 466 & 2,960 & 59.2 & $22.0^{\mathrm{b}}$ & Yes & Yes $^{\mathrm{d}}$ \\
\hline Lead & 1,100 & 353 & $10.2^{\mathrm{b}}$ & $10.2^{\mathrm{b}}$ & Yes & $--^{c}$ \\
\hline Manganese & 552 & 11,200 & $512^{\mathrm{b}}$ & $512^{\mathrm{b}}$ & Yes & Yes $^{\mathrm{d}}$ \\
\hline Mercury & 5 & 24 & $0.33^{\mathrm{b}}$ & $0.33^{\mathrm{b}}$ & Yes & Yes $^{\mathrm{d}}$ \\
\hline Molybdenum & 21.1 & 400 & 8 & $--^{f}$ & Yes & $\mathrm{Yes}^{\mathrm{d}}$ \\
\hline Nickel & $18(<\mathrm{BG})$ & 1,600 & $19.1^{\mathrm{b}}$ & 27.4 & No & -- \\
\hline Selenium & 6.5 & 400 & 5 & 1 & Yes & Yes $^{d}$ \\
\hline \begin{tabular}{|l} 
Silver \\
\end{tabular} & 11.5 & 400 & 8 & $0.73^{b}$ & Yes & $\mathrm{Yes}^{\mathrm{d}}$ \\
\hline Vanadium & 158 & 560 & $85.1^{\mathrm{b}}$ & $-{ }^{\mathrm{f}}$ & Yes & Yes $^{d}$ \\
\hline Zinc & 5,190 & 24,000 & 480 & $67.8^{\mathrm{b}}$ & Yes & Yes $^{d}$ \\
\hline Arochlor-1260 & 2.2 & 0.5 & $0.017^{\mathrm{g}}$ & $0.017^{\mathrm{g}}$ & Yes & $--^{c}$ \\
\hline
\end{tabular}

a Lookup values and RAGs obtained from the Remedial Design Report/Remedial Action Work Plan for the 100 Area (100 Area RDR/RAWP)

(DOE-RL 2005b) or calculated per WAC 173-340-720, WAC 173-340-730, and WAC 173-340-740, Method B, 1996, unless otherwise noted:

b Where cleanup levels are less than background, cleanup levels default to background (WAC 173-340-700[4][d], 1996).

c The maximum concentration is protective of groundwater and the river (footnote $\mathrm{d}$ ), however, the direct exposure criteria has not been met and remediation is required.

' Based on the 100 Area Analogous Sites RESRAD Calculations (BHI 2005), residual concentrations are not expected to migrate more than $3 \mathrm{~m}$ $(9.8 \mathrm{ft}$ ) vertically in 1,000 years based on the lowest soil-partitioning coefficient of those contaminants that exceeded the RAG (copper; $22 \mathrm{~mL} / \mathrm{g})$. The vadose zone underlying the remediation footprint is approximately $5.8 \mathrm{~m}(19.0 \mathrm{ft})$ thick. Therefore, residual concentrations of these contaminants are predicted to be protective of groundwater and the Columbia River.

' Carcinogenic cleanup level calculated based on the inhalation exposure pathway (WAC 173-340-750[3], 1996) and an airborne particulate massloading rate of $0.0001 \mathrm{~g} / \mathrm{m}^{3}$ (WDOH 1997).

${ }^{f}$ No cleanup level is available from the Cleanup Levels and Risk Calculations (CLARC) database (Ecology 2005) and/or no bioconcentration factors or ambient water quality criteria values are available to calculate soil cleanup levels protective of the river.

$g$ Where cleanup levels are less than the required detection limit (RDL), the cleanup level defaults to the RDL (WAC 173-340-707[2], 1996, and DOE-RL 2005b).

\begin{tabular}{|c|c|c|c|}
\hline -- & $=$ not applicable & PCB & = polychlorinated biphenyl \\
\hline BG & $=$ background & RAG & $=$ remedial action goal \\
\hline GW & $=$ groundwater & RESRAD & $=$ RESidual RADioactivity (dose model) \\
\hline COPC & $=$ contaminant of potential concern & WAC & $=$ Washington Administrative Code \\
\hline
\end{tabular}


Table 6. Comparison of Septic Tank (Area 6) Sample Results to Action Levels.

\begin{tabular}{|c|c|c|c|c|c|c|}
\hline \multirow[b]{2}{*}{ COPC } & \multirow[b]{2}{*}{$\begin{array}{c}\text { Maximum } \\
\text { Result } \\
(\text { pCi/g) }\end{array}$} & \multicolumn{3}{|c|}{ Generic Site Lookup Values (pCi/g) ${ }^{\mathrm{a}}$} & \multirow{2}{*}{$\begin{array}{c}\text { Does the } \\
\text { Maximum Result } \\
\text { Exceed Lookup } \\
\text { Value? }\end{array}$} & \multirow{2}{*}{$\begin{array}{c}\text { Does RESRAD } \\
\text { Indicate GW and } \\
\text { River } \\
\text { Protectiveness? }\end{array}$} \\
\hline & & $\begin{array}{c}\text { Direct } \\
\text { Exposure }\end{array}$ & \begin{tabular}{|c|} 
Soil Standard for \\
Groundwater \\
Protection
\end{tabular} & \begin{tabular}{|l|} 
Soil Standard \\
for River \\
Protection
\end{tabular} & & \\
\hline \multicolumn{7}{|c|}{ Radionuclides (pCi/g) } \\
\hline \multicolumn{7}{|c|}{ No radionuclides detected above the minimum detectable activity or background concentrations. } \\
\hline \multirow[b]{2}{*}{ COPC } & \multirow[b]{2}{*}{$\begin{array}{c}\text { Maximum } \\
\text { Result } \\
\text { (mg/kg) }\end{array}$} & \multicolumn{3}{|c|}{ Remedial Action Goals (mg/kg) ${ }^{\mathrm{a}}$} & \multirow[b]{2}{*}{$\begin{array}{c}\text { Does the } \\
\text { Maximum Result } \\
\text { Exceed RAG? }\end{array}$} & \multirow{2}{*}{\begin{tabular}{|c|} 
Does RESRAD \\
Indicate GW and \\
River \\
Protectiveness?
\end{tabular}} \\
\hline & & $\begin{array}{c}\text { Direct } \\
\text { Exposure }\end{array}$ & \begin{tabular}{|c|} 
Soil Standard for \\
Groundwater \\
Protection
\end{tabular} & \begin{tabular}{|l|} 
Soil Standard \\
for River \\
Protection
\end{tabular} & & \\
\hline \multicolumn{7}{|c|}{ Nonradionuclides $(\mathrm{mg} / \mathrm{kg})$} \\
\hline Arsenic & 15.7 & $20^{\mathrm{b}}$ & \begin{tabular}{|l|}
20 \\
\end{tabular} & 20 & No & -- \\
\hline Barium & 291 & 5,600 & $132^{\mathrm{b}}$ & 224 & Yes & Yes $^{\mathrm{d}}$ \\
\hline Beryllium & $0.63(<\mathrm{BG})$ & $10.4^{\mathrm{e}}$ & $1.51^{\mathrm{b}}$ & $1.51^{\mathrm{b}}$ & No & -- \\
\hline Boron & 3 & 16,000 & 320 & $--^{c}$ & No & -- \\
\hline Cadmium & 2.7 & 13.9 & $0.81^{\mathrm{b}}$ & $0.81^{\mathrm{b}}$ & Yes & $\mathrm{Yes}^{\mathrm{d}}$ \\
\hline Chromium (total) & $14.6(<\mathrm{BG})$ & 80,000 & $18.5^{\mathrm{b}}$ & $18.5^{\mathrm{b}}$ & No & -- \\
\hline Cobalt & $8.4(<\mathrm{BG})$ & 1,600 & 32 & $--^{c}$ & No & -- \\
\hline Copper & 92.4 & 2,960 & 59.2 & $22.0^{\mathrm{b}}$ & Yes & $\mathrm{Yes}^{\mathrm{d}}$ \\
\hline Lead & 81.1 & 353 & $10.2^{\mathrm{b}}$ & $10.2^{\mathrm{b}}$ & Yes & $\mathrm{Yes}^{\mathrm{d}}$ \\
\hline Manganese & $397(<\mathrm{BG})$ & 11,200 & $512^{\mathrm{b}}$ & $512^{\mathrm{b}}$ & No & -- \\
\hline Mercury & 0.6 & 24 & $0.33^{\mathrm{b}}$ & $0.33^{\mathrm{b}}$ & Yes & Yes $^{d}$ \\
\hline Molybdenum & 5.6 & 400 & 8 & $--^{c}$ & No & -- \\
\hline Nickel & $17(<\mathrm{BG})$ & 1,600 & $19.1^{\mathrm{b}}$ & 27.4 & No & - \\
\hline Selenium & $0.49(<\mathrm{BG})$ & 400 & 5 & 1 & No & -- \\
\hline Silver & 1.9 & 400 & 8 & $0.73^{\mathrm{b}}$ & Yes & $\mathrm{Yes}^{\mathrm{d}}$ \\
\hline Vanadium & $79.8(<\mathrm{BG})$ & 560 & $85.1^{\mathrm{b}}$ & $--^{c}$ & No & -- \\
\hline Zinc & 578 & 24,000 & 480 & $67.8^{\mathrm{e}}$ & Yes & $\mathrm{Yes}^{\mathrm{d}}$ \\
\hline Aroclor-1260 & 1.1 & 0.5 & $0.017^{\mathrm{f}}$ & $0.017^{\mathrm{f}}$ & Yes & $-\mathrm{g}^{\mathrm{g}}$ \\
\hline Benzo(a)anthracene & 0.055 & 1.37 & $0.33^{f}$ & $0.33^{f}$ & No & -- \\
\hline Bis(2-ethylhexyl) phthalate & 0.100 & 71.4 & 0.6 & 0.36 & No & -- \\
\hline Chrysene & 0.073 & 137 & 1.2 & $0.33^{\mathrm{f}}$ & No & -- \\
\hline Fluoranthene & 0.170 & 3,200 & 64 & 18.0 & No & -- \\
\hline
\end{tabular}

" Lookup values and RAGs obtained from the Remedial Design Report/Remedial Action Work Plan for the 100 Area (100 Area RDR/RAWP) (DOE-RL 2005b) or calculated per WAC 173-340-720, WAC 173-340-730, and WAC 173-340-740, Method B, 1996, unless otherwise noted.

b Where cleanup levels are less than background, cleanup levels default to background (WAC 173-340-700[4][d], 1996).

${ }^{c}$ No cleanup level is available from the Cleanup Levels and Risk Calculations (CLARC) database (Ecology 2005) and/or no bioconcentration factors or ambient water quality criteria values are available to calculate soil cleanup levels protective of the river.

'Based on the 100 Area Analogous Sites RESRAD Calculations (BHI 2005), residual concentrations are not expected to migrate more than 3 m $(9.8 \mathrm{ft}$ ) vertically in 1,000 years based on the lowest soil-partitioning coefficient of those contaminants that exceeded the RAG (copper; $22 \mathrm{~mL} / \mathrm{g})$. The vadose zone underlying the remediation footprint is approximately $5.8 \mathrm{~m}(19.0 \mathrm{ft})$ thick. Therefore, residual concentrations of these contaminants are predicted to be protective of groundwater and the Columbia River.

${ }^{e}$ Carcinogenic cleanup level calculated based on the inhalation exposure pathway (WAC 173-340-750[3], 1996) and an airborne particulate massloading rate of $0.0001 \mathrm{~g} / \mathrm{m}^{3}$ (WDOH 1997).

${ }^{f}$ Where cleanup levels are less than the required detection limit (RDL), the cleanup level defaults to the RDL (WAC 173-340-707[2], 1996 and DOE-RL 2005b)

g The maximum concentration is protective of groundwater and the river (footnote d), however, the direct exposure criteria has not been met and remediation is required.

\begin{tabular}{|c|c|c|c|}
\hline-- & $=$ not applicable & PCB & $=$ polychlorinated biphenyl \\
\hline $\mathrm{BG}$ & $=$ background & RAG & $=$ remedial action goal \\
\hline COPC & $=$ contaminant of potential concern & RESRAD & $=$ RESidual RADioactivity (dose model) \\
\hline GW & $=$ groundwater & WAC & $=$ Washington Administrative Code \\
\hline
\end{tabular}




\section{Radionuclides}

As previously discussed, several radionuclides had analytical results above the minimum detectable activity (Appendix A) but were not included in further evaluations because they are part of natural background or have activities less than Hanford Site background. No other radionuclides were detected in samples collected from the septic tank, the septic drain field, or the 120 Experimental Building location. Cesium- 137 was detected at $0.361 \mathrm{pCi} / \mathrm{g}$ in the sample collected from the 123 Control Building location (Area 1). Americium-241 and plutonium-239/240 were detected above Hanford Site background at $0.266 \mathrm{pCi} / \mathrm{g}$ and $0.816 \mathrm{pCi} / \mathrm{g}$, respectively, in the sample collected from the P-11 Crib location (Area 2). These radionuclide values were entered into the RESidual RADioactivity (RESRAD) computer code, Version 6.21 (ANL 2002), to estimate the dose rate and to estimate the impact on groundwater and the river from residual radionuclide activity.

The results of the RESRAD modeling are reported in 600-111, P-11 Critical Mass Laboratory RESRAD Calculation Brief (BHI 2004a). The RESRAD dose rate estimate for the all-pathways scenario for the 600-111 site is below the $15 \mathrm{mrem} / \mathrm{yr}$ RAG. The maximum all-pathways dose rate was $1.32 \mathrm{mrem} / \mathrm{yr}$ (from Area 1) in RESRAD model year zero (2004), and is predecited to decrease to $0.38 \mathrm{mrem} / \mathrm{yr}$ in 1,000 years (Figure 5). The maximum predicted radionuclide excess lifetime cancer risk also occurred in 2004 at $1.49 \times 10^{-5}$, which is within the Comprehensive Environmental Response, Compensation, and Liability Act of 1980 risk range of $10^{-4}$ to $10^{-6}$ (Figure 6). The RESRAD model predicts that no radionuclide reaches groundwater within 1,000 years. Therefore, the 600-111 site meets the radionuclide RAGs for direct exposure and protection of groundwater and the Columbia River, and no further verification sampling or remediation due to residual radiological contamination at the site is required. However, as discussed below, removal of the septic tank and drain field was required due to the presence of nonradionuclide constituents.

An intensive radiological surface soil survey of the entire footprint of the 600-111 site was performed May 26 through June 2, 2004, using a FIDLER to support evaluation of potential radiological contamination associated with the UPR-600-16 waste site. The survey was performed on a grid over an area of $7,414 \mathrm{~m}^{2}$ to achieve a minimum of $90 \%$ coverage of the surface soil. Approximately 58,500 measurements were recorded by the instrumentation. The results of the FIDLER survey are shown in Figure 4. As previously stated, only 10 of the measurements were greater than background activity; however, they were still less than twice background. The coordinates for the location of the most elevated detectable reading were then used to find the location in the field. The survey team inspected the location and found a large boulder at the surface. Direct readings of the boulder and the soil below the boulder and smears of the boulder itself revealed that the activity was related to natural radioactivity associated with the mineralogical composition of the boulder and not due to contamination from Hanford Site operations or the criticality excursion. This information was discussed with the EPA Project Manager, and it was decided that surface soil samples were not necessary because the few detectable measurements were well below background and the most elevated measurement was due to natural radioactivity. Therefore, this information is used to support closeout of the UPR-600-16 waste site. 
Figure 5. Radionuclide Dose Rate - All Pathways for the 600-111 Site.

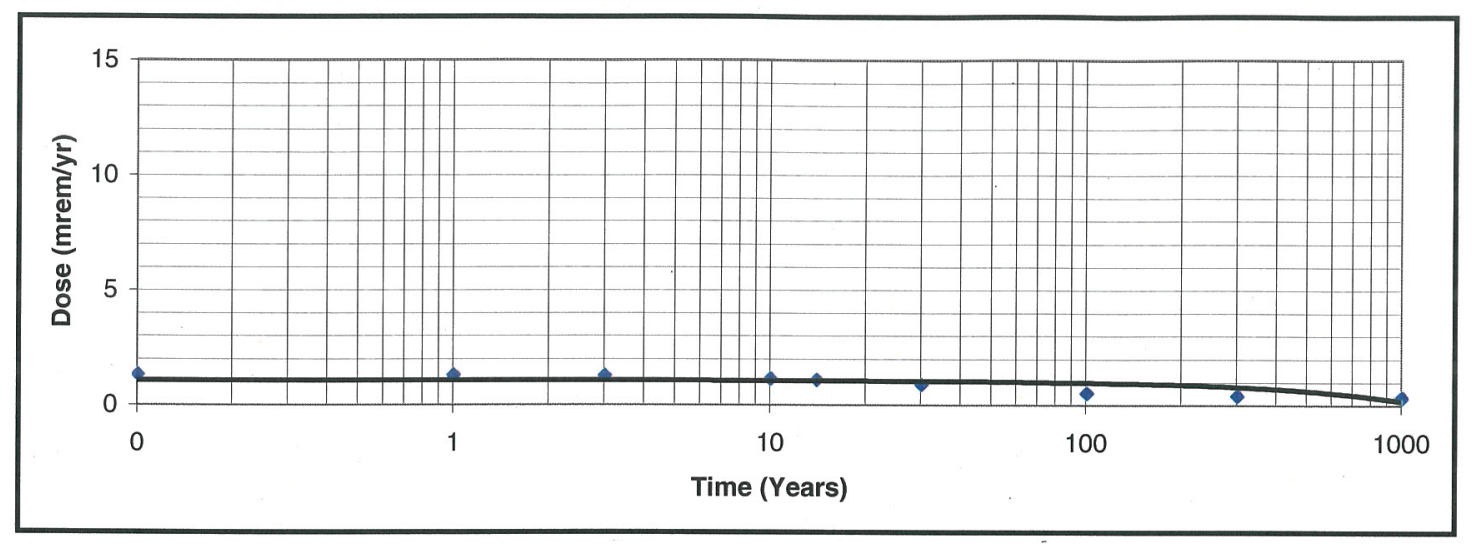

Figure 6. Estimated Radionuclide Excess Cancer Risk.

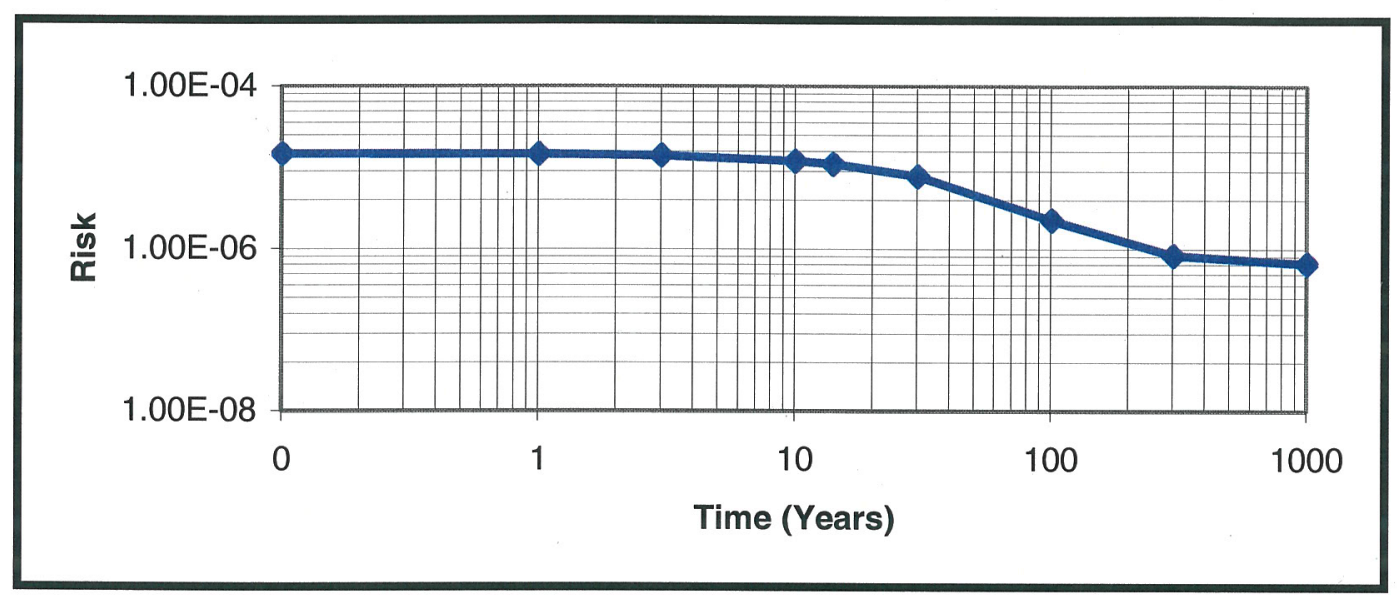

\section{Nonradionuclides}

The confirmatory sampling results for the 120 Experimental Building location (Area 1), the P-11 Crib location (Area 2), the 123 Control Building location (Area 3), the septic drain field (Area 5), and the septic tank (Area 6) were compared to the action levels to determine if the cleanup criteria were met or if remediation was necessary (Tables 2 through 6). The results for the nonradionuclide constituents indicate that the cleanup criteria were met for the P-11 Crib location, the 120 Experimental Building location, and the 123 Control Building location. However, removal of the septic system, including the tank, drain field, and connecting pipeline, was required due to the presence of PCBs, arsenic, cadmium, and lead exceeding the direct exposure RAGs (Tables 5 and 6). Other metals including barium, chromium, copper, manganese, mercury, molybdenum, selenium, silver, vanadium, and zinc were detected in concentrations exceeding the groundwater and river protection RAGs. 


\section{REMEDIAL ACTION SUMMARY}

Remediation of the septic system tank and drain field located at the 600-111 waste site was performed between February 25, 2008 and March 25, 2008. As previously stated, laboratory analysis of confirmatory samples collected within the building footprint of the former 123 Control Building, the removed P-11 Crib, and the building footprint of the former 120 Experimental Building met the remedial action goals, and, therefore, no additional remedial action in these areas was necessary. The septic system tank and drain field were excavated to approximately $4.6 \mathrm{~m}(15 \mathrm{ft}$ ) below grade (at the deepest portion) resulting in a combined volume of approximately $2,755 \mathrm{~m}^{3}\left(3,603 \mathrm{yd}^{3}\right)$ of material removed and disposed at the Environmental Restoration Disposal Facility. Figure 7 provides the post-excavation civil survey of the remediation area. Figure 8 provides a photograph of the site after completion of remedial actions. The septic tank (Figure 9), inlet pipe (Figure 10), encased pipe (Figure 11), vitrified clay pipe associated with the drain field (Figure 12), and contaminated soil associated with the septic system were all removed.

\section{Radiological Survey}

The surface soil over the footprint of the entire septic system excavation and surrounding area was evaluated after remediation using field radiological survey instrumentation. In consideration of the history of the 600-111 site, this comprehensive radiological survey was performed as a precautionary measure to supplement the confirmatory sampling results that indicated radionuclide contamination was not present in the septic system. The survey was performed on a grid, collecting 13,389 measurements, and achieved approximately $90 \%$ to $100 \%$ coverage. The detector selected was a Model 44-17 Ludlum because it is sensitive to detection of the low-energy gamma radiation associated with americium-241, a daughter isotope of plutonium-241. The results of the survey were used to determine if any areas of residual plutonium contamination could be found. As shown in Figure 13, no residual radiological contamination exceeding twice background was detected and evaluation of the distribution of measurements above background was well within the range of random statistics.

\section{VERIFICATION SAMPLING ACTIVITIES}

RAGs are the specific numeric goals against which the cleanup verification data are evaluated to demonstrate attainment of the remedial action objectives for the site. Verification sampling for the septic system at the 600-111 waste site was performed on April 21,2008, to collect data to determine if the RAGs had been met (WCH 2008a). The following subsections provide additional discussion of the information used to develop the verification sampling design. The results of verification sampling are also summarized to support interim closure of the site. 
Figure 7. Post-Excavation Civil Survey Map.

$\mathrm{G}: \backslash I U-2 \_I U-6 \backslash 600-111 \backslash 600-111$ _Topo_Fig1.dwg
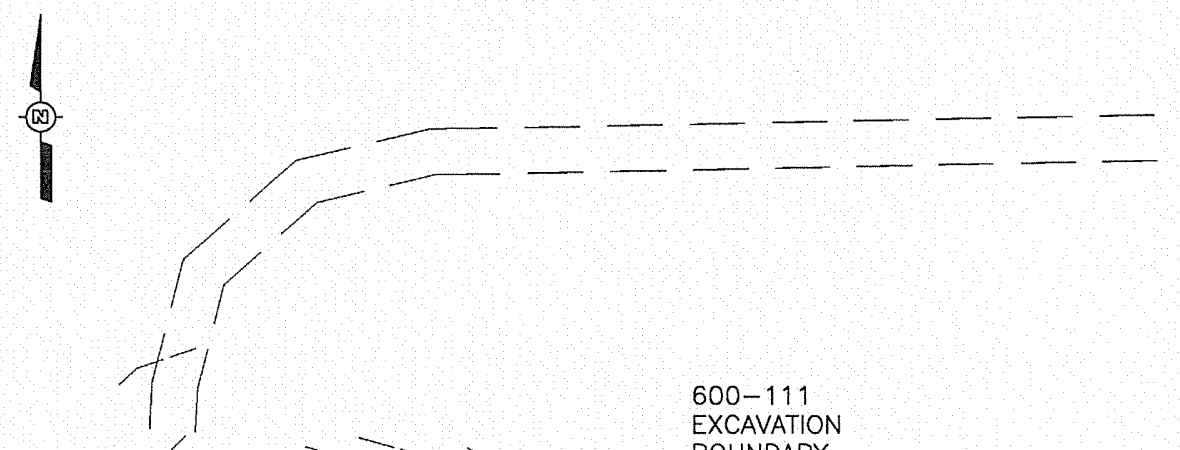

$600-111$

EXCAVATION

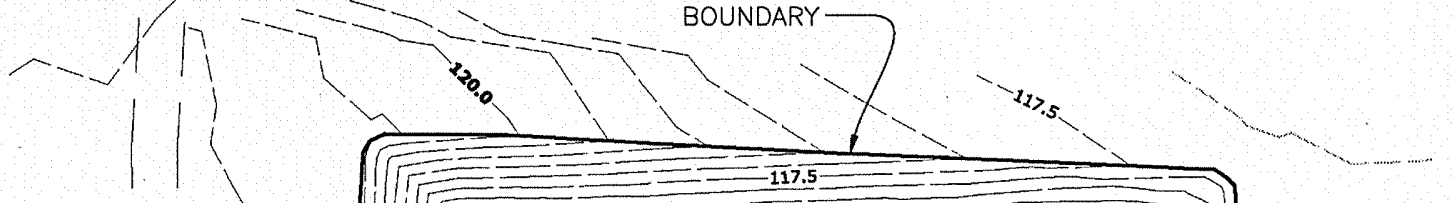

1
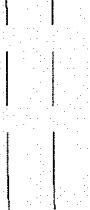

$\angle-$
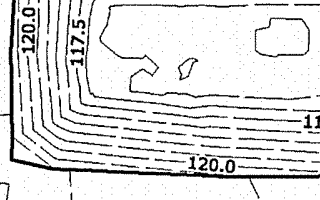

$\nabla$

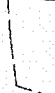

11
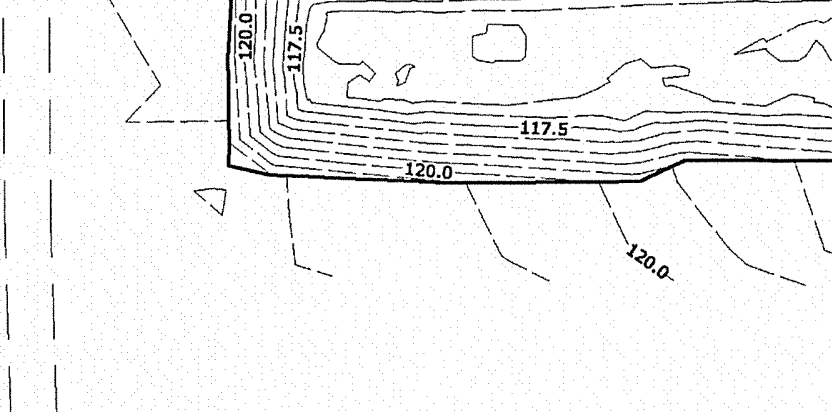

1

1
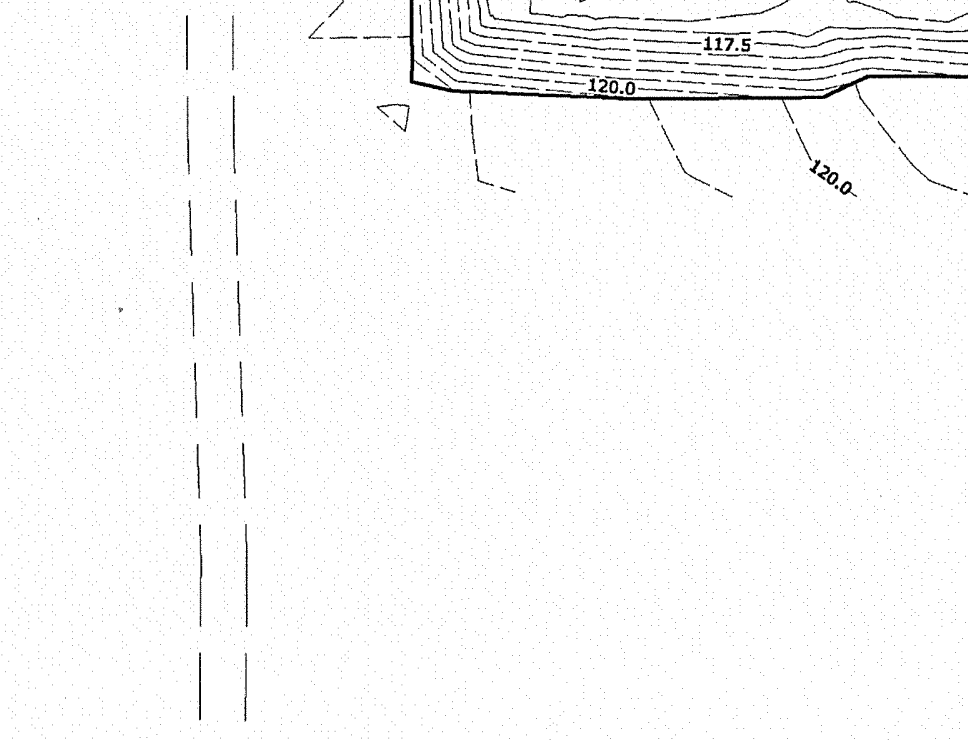

\section{Legend}

$$
=\text { = Unpaved Road }
$$

Note: 1. Vertical Datum: North America Vertical Datum of 1988 (NAVD88) 2. Elevation Contours In 0.5 Meter Intervals.

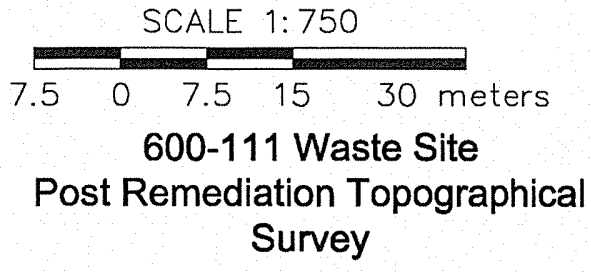

Survey 
Figure 8. 600-111 Septic System Excavation.

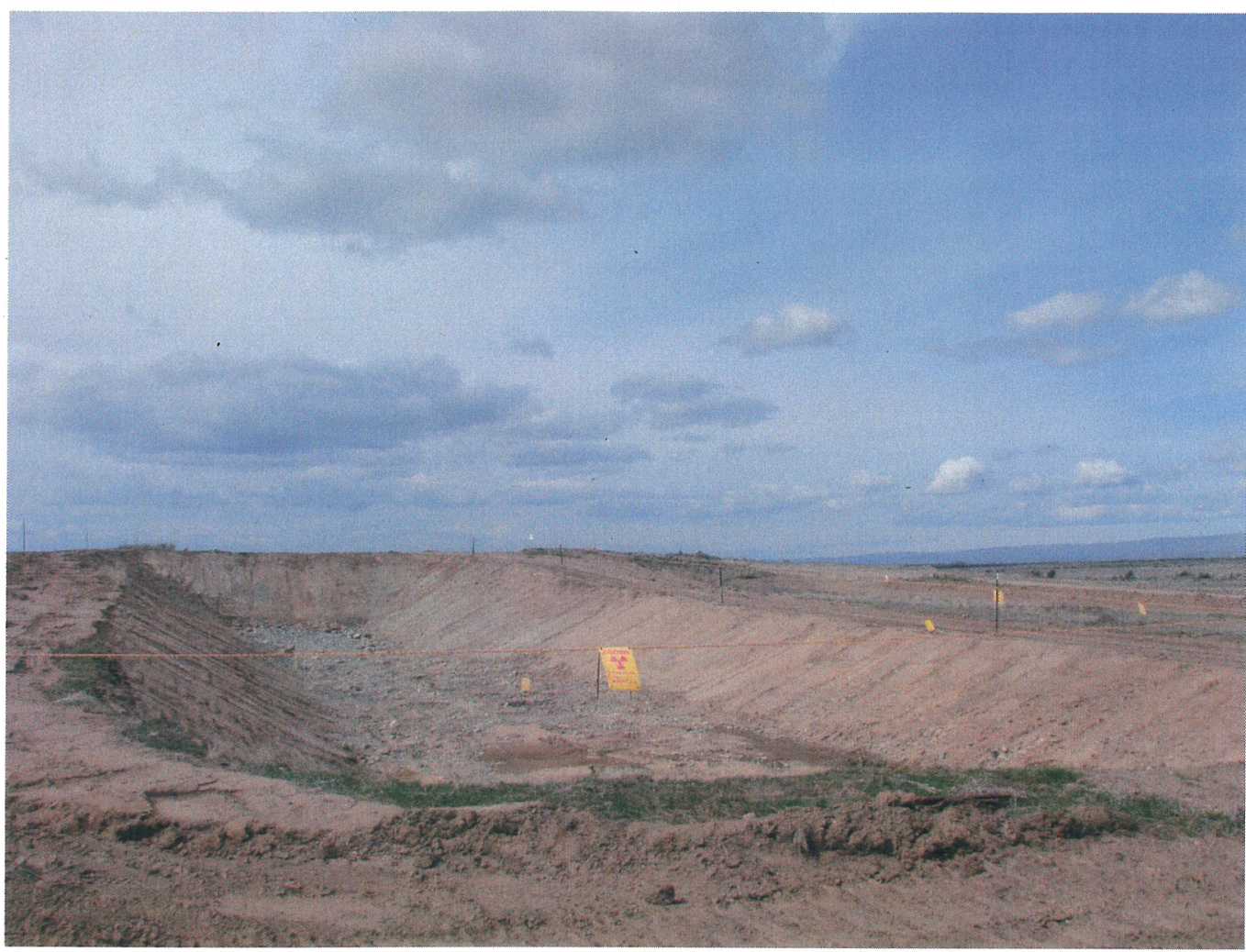

Figure 9. 600-111 Septic Tank.

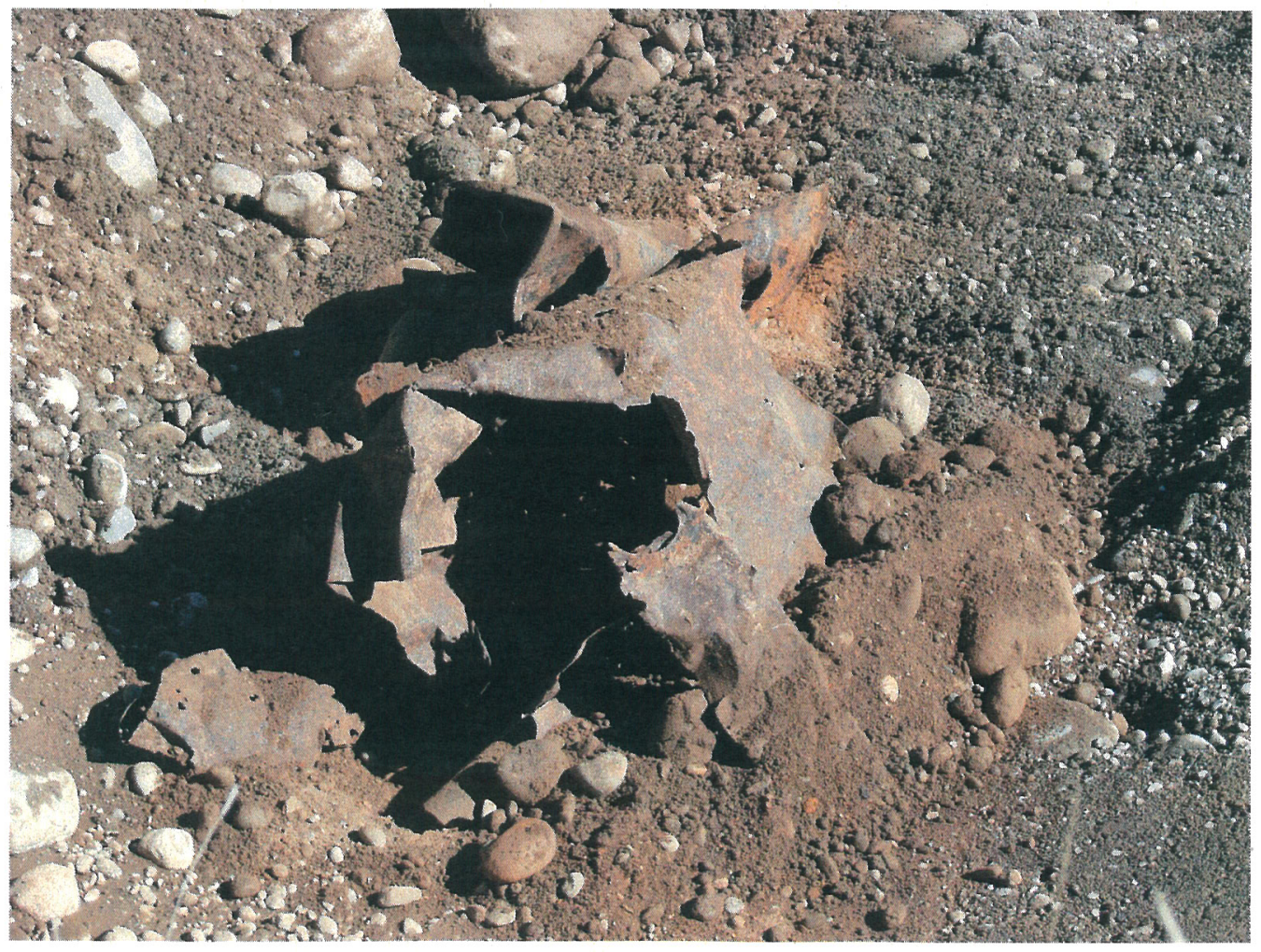


Figure 10. 600-111 Cast Iron Inlet Pipeline.

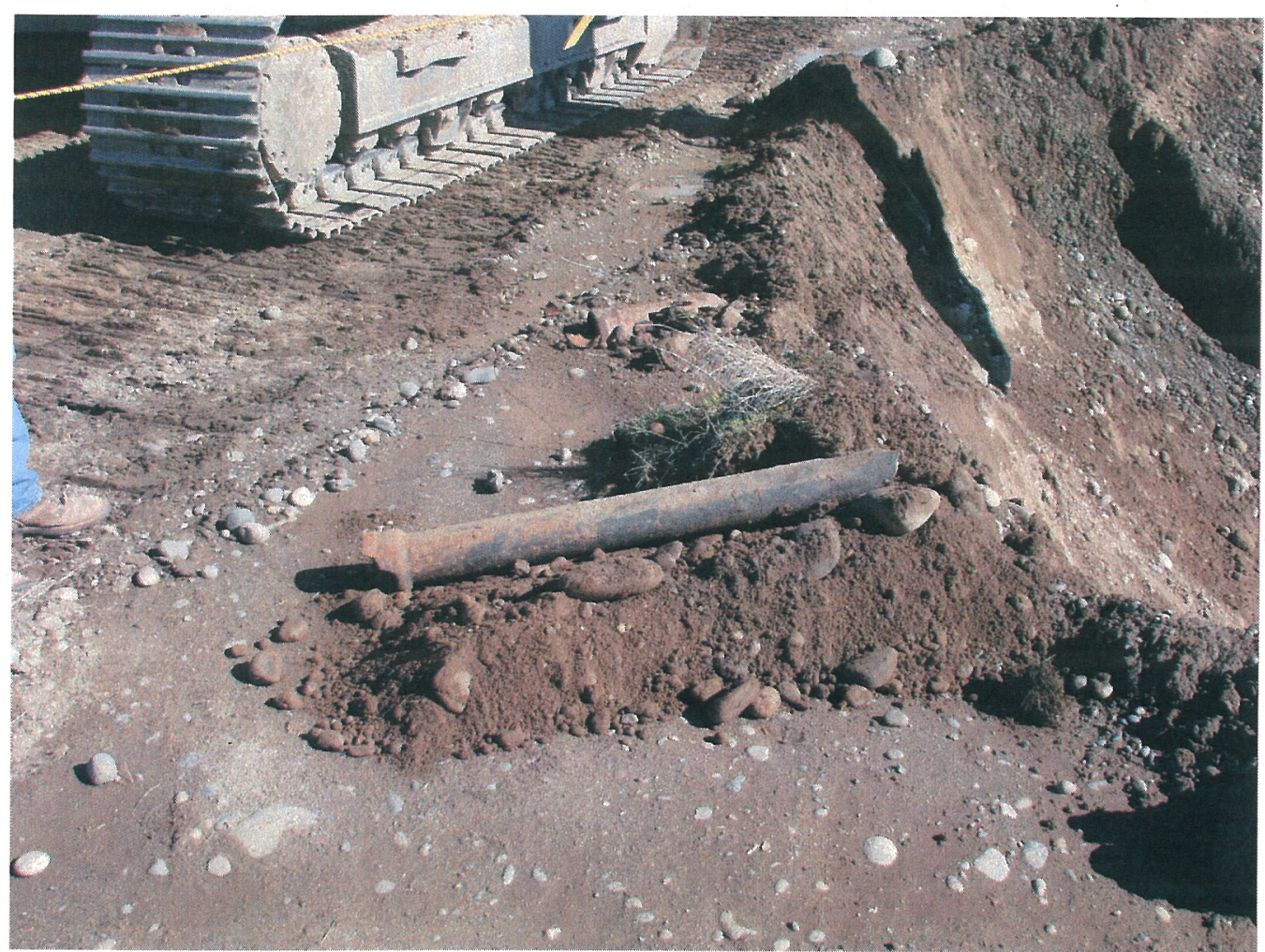

Figure 11. 600-111 Encased Pipeline Located Between Septic Tank and Septic Drain Field.

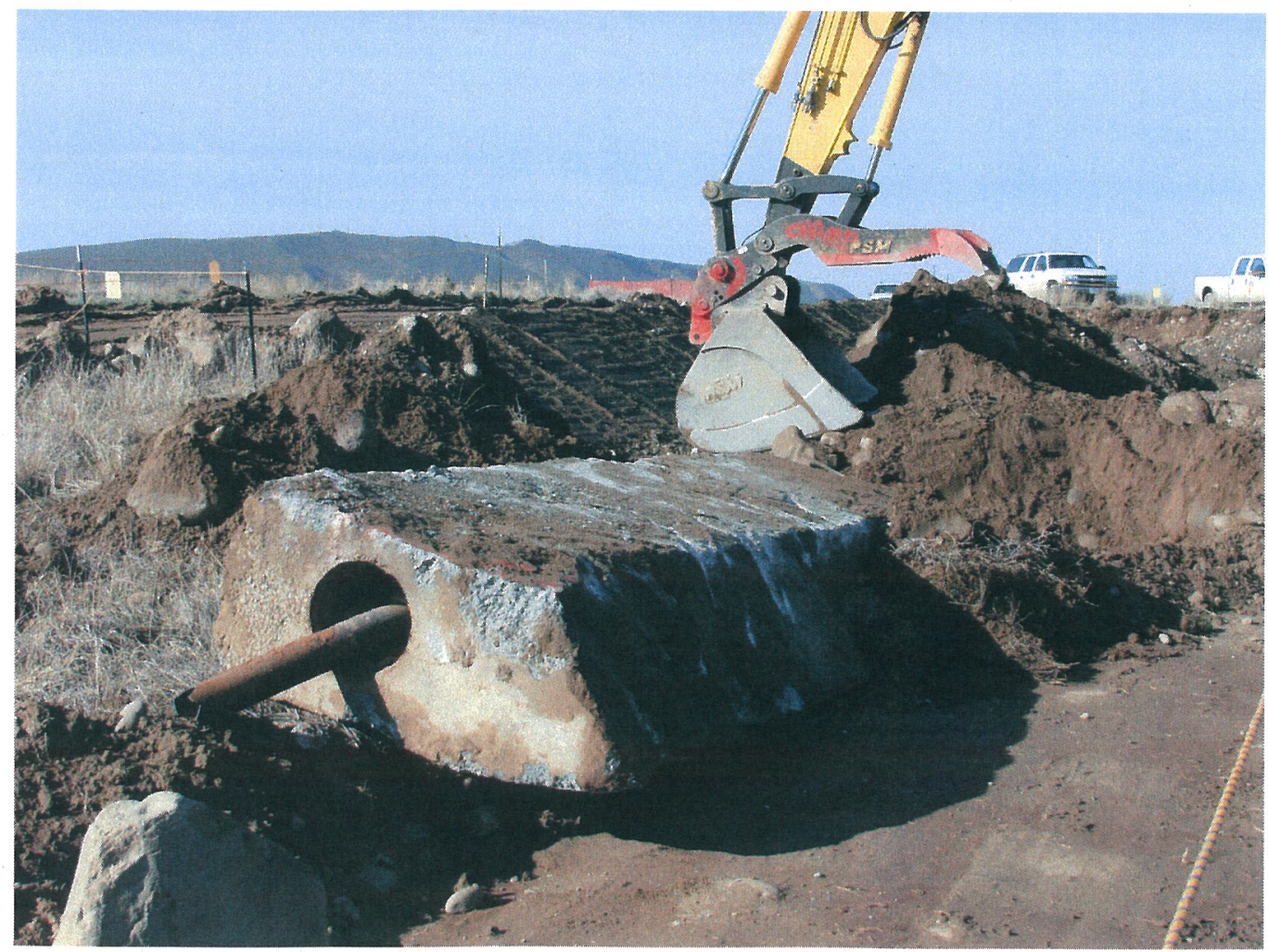




\section{Figure 12. Vitrified Clay Drain Field Pipe.}

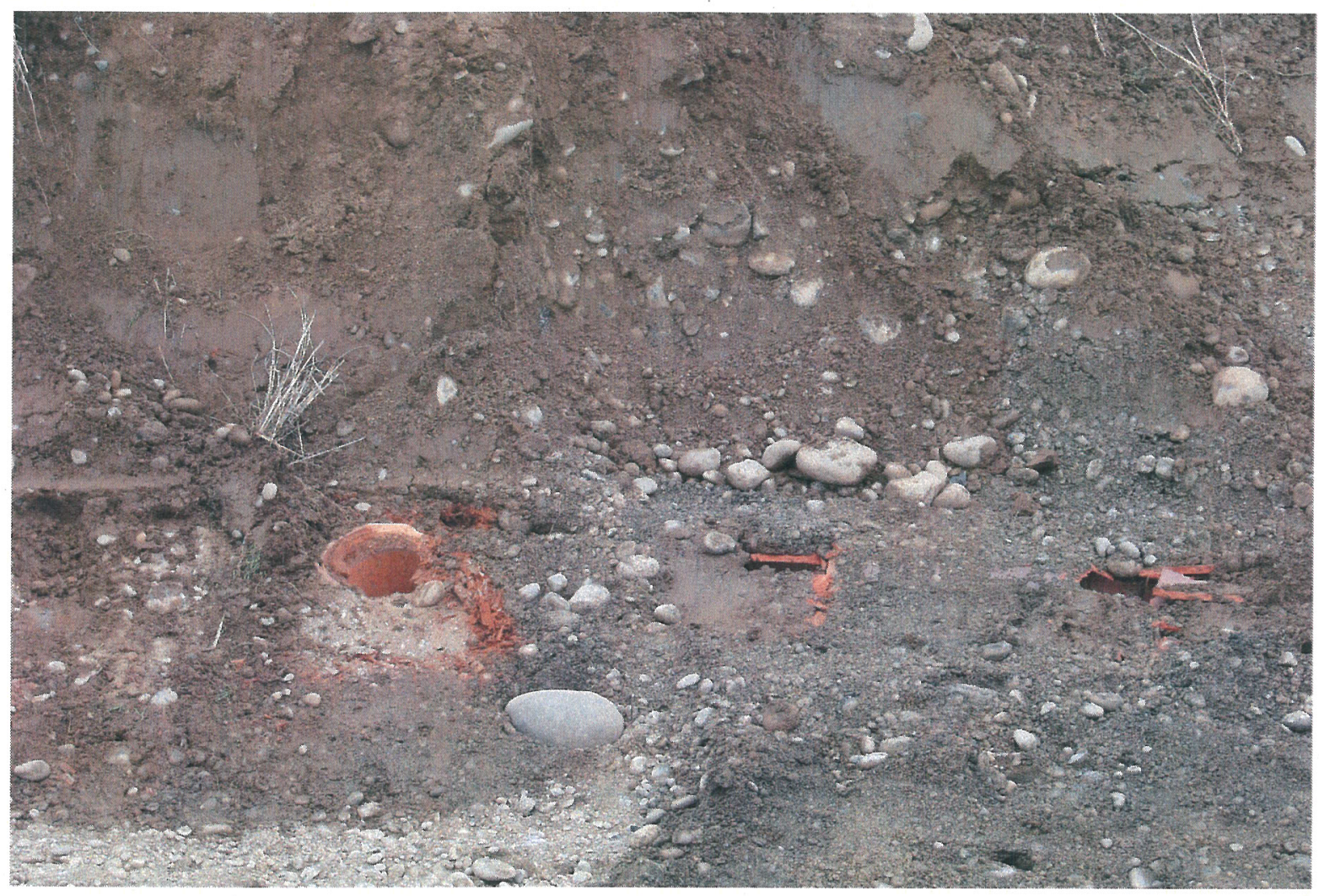

\section{Contaminants of Potential Concern}

The contaminants of concern (COCs) and COPCs for the 600-111 septic system were established using the confirmatory sampling analytical results (Appendix A). The COCs include arsenic, barium, cadmium, chromium, copper, lead, manganese, mercury, molybdenum, selenium, silver, vanadium, zinc, and aroclor-1260. The verification samples were also analyzed for semivolatile compounds because the detection limits were elevated for confirmatory samples collected from the septic tank and drain field.

Radionuclides were eliminated as COPCs for the 600-111 septic system because no radionuclides were detected above the minimum detectable activity or background activity in the confirmatory samples.

\section{Verification Sample Design}

This subsection describes the basis for selection of an appropriate sample design and determination of the number of verification samples that were collected. Global positioning survey instrumentation was used to delineate the boundary of the septic system excavation as shown in Figure 14. A statistical sampling approach was used for evaluation of the remediation.

The decision rule for demonstrating compliance with the cleanup criteria requires comparison of the true population mean, as estimated by the $95 \%$ upper confidence limit on the sample mean, 


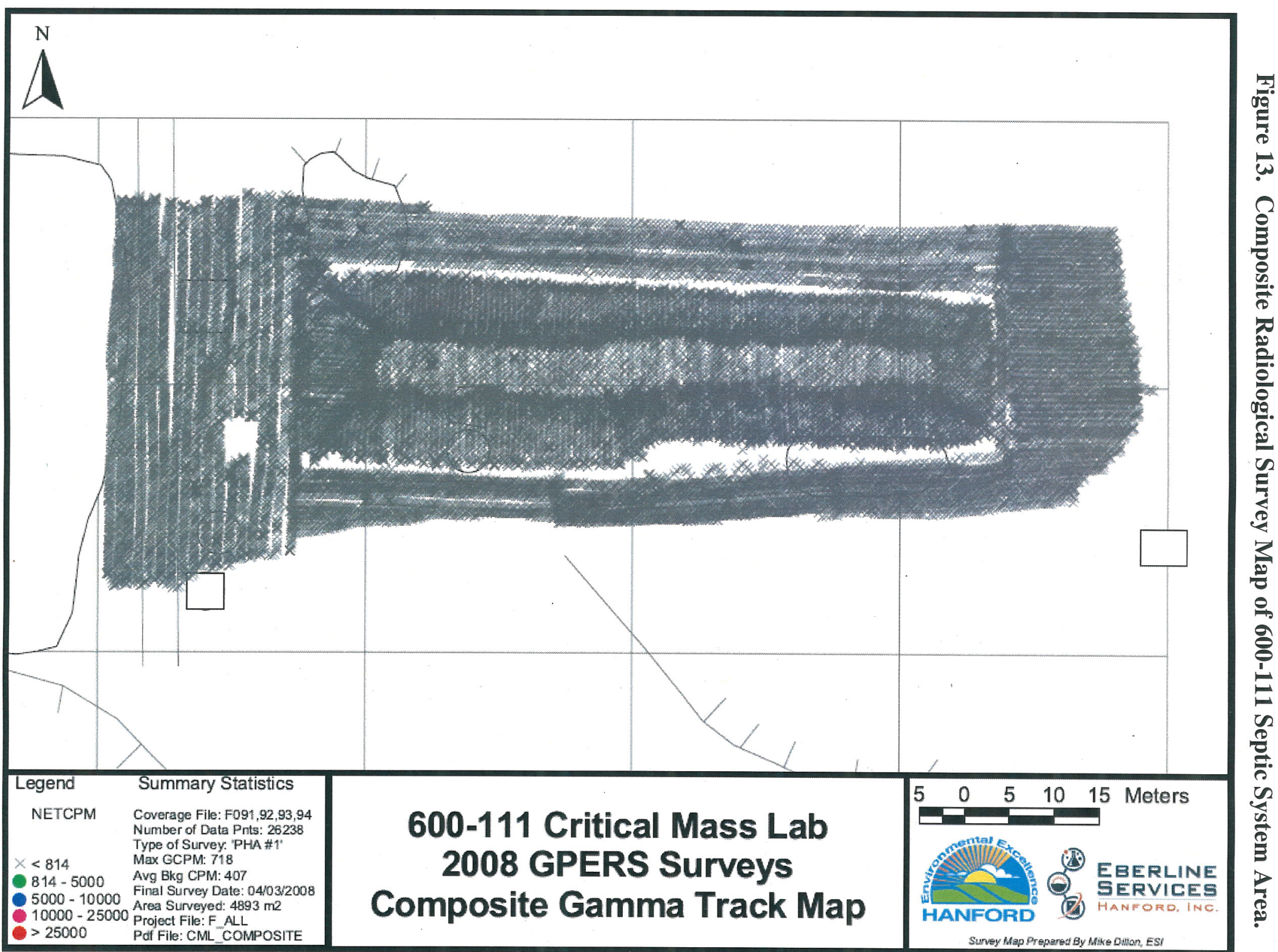



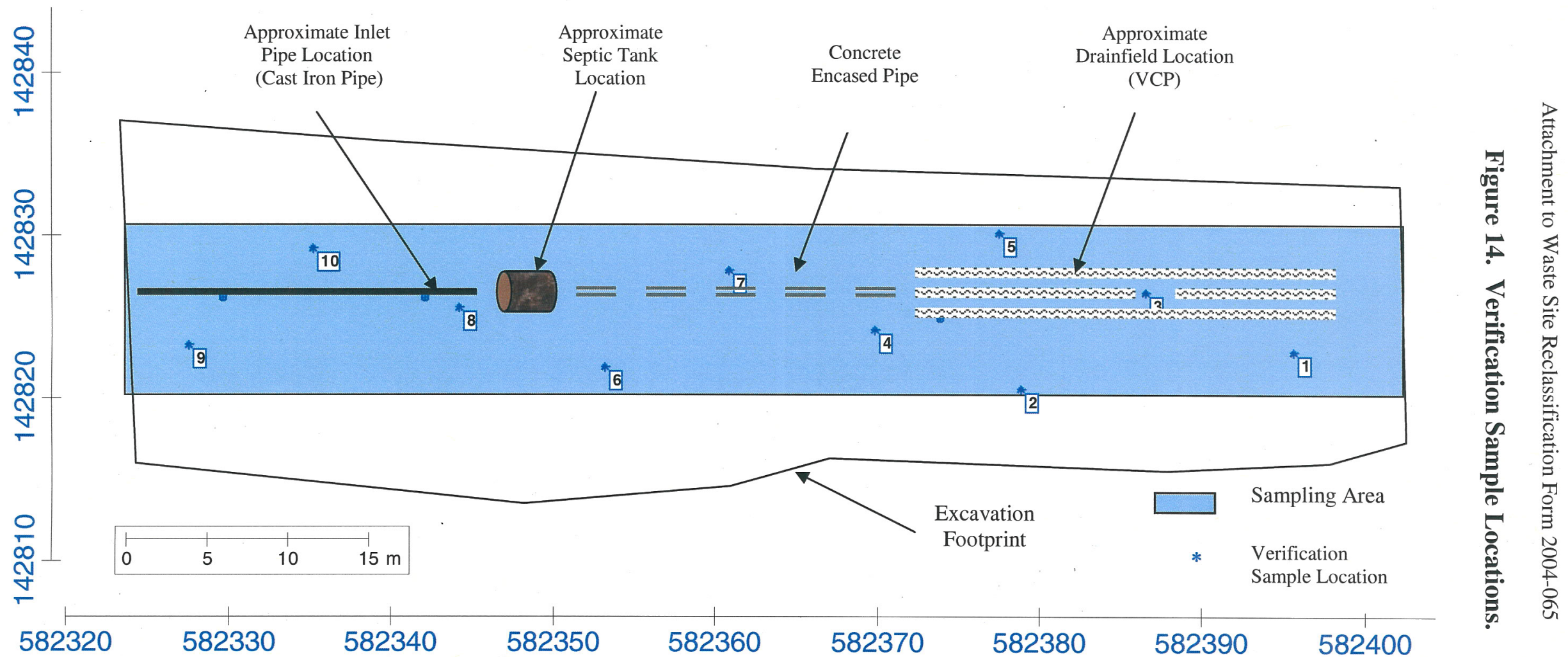
with the cleanup level. Therefore, a statistical sampling design was the preferred verification sampling approach for this site, because the distribution of potential residual soil contamination over the site is uncertain. The Washington State Department of Ecology publication Guidance on Sampling and Data Analysis Methods (Ecology 1995) recommends that systematic sampling with sample locations distributed over the entire study area be used. This sampling approach is referred to by the Washington State Department of Ecology as "area-wide sampling." Additional discussion of the development of the statistical verification sampling design for the 600-111 septic system is provided in the 600-111 verification work instruction (WCH 2008b).

Statistical parameters (i.e., standard deviation within the population) for residual contaminant levels at the 600-111 septic system site were unknown. Therefore, the standard deviations of the residual concentrations for each contaminant were assumed to be less than $25 \%$ of the corresponding decision threshold for each contaminant. This assumption was verified using the resulting verification sampling data (Appendix $\mathrm{C}$ ) to ensure that an adequate number of verification samples were collected.

The sampling area was bounded, at the base of the excavation, by a distance of approximately $5 \mathrm{~m}$ (16.4 ft) on each side of the septic system structure. Visual Sample Plan ${ }^{1}$ (VSP) was used to delineate the sampling area and apply a random-start systematic grid to it for verification soil sample collection. Ten verification soil samples were collected on a random-start grid for this sampling area (Figure 14). A triangular grid was selected for this investigation based on studies that indicate triangular grids are superior to square grids (Gilbert 1987).

The soil sample locations were surveyed and staked prior to sample collection (WCH 2008a, 2008b), and one discrete soil sample was collected at each location. All sampling was performed in accordance with ENV-1, Environmental Monitoring \& Management, to fulfill the requirements of the 100 Area Remedial Action Sampling and Analysis Plan (DOE-RL 2005a).

Field quality control šamples consisted of one equipment blank sample and one field duplicate sample. All samples were submitted for full protocol laboratory analysis.

A summary of the samples collected and the analyses performed for the verification sampling event are presented in Table 7.

Table 7. Verification Sample Summary for the 600-111 Waste Site Septic System. ${ }^{a}$ (2 Pages)

\begin{tabular}{|c|c|c|c|c|c|}
\hline $\begin{array}{c}\text { Sample } \\
\text { Location }\end{array}$ & $\begin{array}{l}\text { Sample } \\
\text { Media }\end{array}$ & $\begin{array}{c}\text { Sample } \\
\text { Number }\end{array}$ & $\begin{array}{l}\text { Northing } \\
(\mathbf{m})^{b}\end{array}$ & $\begin{array}{c}\text { Easting } \\
(\mathrm{m}) \mathrm{b}\end{array}$ & Sample Analysis \\
\hline 1 & Soil & J16MM8 & 582395.6 & 142822.9 & ICP metals, ${ }^{c}$ mercury, PCBs, and SVOAs \\
\hline 2 & Soil & J16MM9 & 582378.9 & 142820.6 & ICP metals ${ }^{c}$ mercury, PCBs, and SVOAs \\
\hline 3 & Soil & J16MN0 & 582386.6 & 142826.5 & ICP metals ${ }^{c}$ mercury, PCBs, and SVOAs \\
\hline 4 & Soil & $\mathrm{J} 16 \mathrm{MN} 1$ & 582369.9 & 142824.2 & ICP metals, ${ }^{c}$ mercury, $\mathrm{PCBs}$, and SVOAs \\
\hline
\end{tabular}

\footnotetext{
${ }^{1}$ Visual Sample Plan is a site map-based user-interface program that may be downloaded at http://dqo.pnl.gov.
} 
Table 7. Verification Sample Summary for the 600-111 Waste Site Septic System. ${ }^{a}$ (2 Pages)

\begin{tabular}{|c|c|c|c|c|c|}
\hline $\begin{array}{c}\text { Sample } \\
\text { Location }\end{array}$ & $\begin{array}{l}\text { Sample } \\
\text { Media }\end{array}$ & $\begin{array}{l}\text { Sample } \\
\text { Number }\end{array}$ & $\begin{array}{l}\text { Northing } \\
(\mathbf{m})^{\mathbf{b}}\end{array}$ & $\begin{array}{c}\text { Easting } \\
(\mathbf{m})^{b}\end{array}$ & Sample Analysis \\
\hline 5 & Soil & $\mathrm{J} 16 \mathrm{MN} 2$ & 582377.6 & 142830.2 & ICP metals, ${ }^{c}$ mercury, PCBs, and SVOAs \\
\hline 6 & Soil & $\mathrm{J} 16 \mathrm{MN} 3$ & 582353.2 & 142821.9 & ICP metals, ${ }^{c}$ mercury, PCBs, and SVOAs \\
\hline 7 & Soil & $\mathrm{J} 16 \mathrm{MN} 4$ & 582360.9 & 142827.9 & ICP metals, ${ }^{c}$ mercury, PCBs, and SVOAs \\
\hline 8 & Soil & J16MN5 & 582344.2 & 142825.6 & ICP metals, ${ }^{c}$ mercury, PCBs, and SVOAs \\
\hline 9 & Soil & $\mathrm{J} 16 \mathrm{MN} 7$ & 582327.5 & 142823.3 & ICP metals, ${ }^{c}$ mercury, PCBs, and SVOAs \\
\hline 10 & Soil & J16MN8 & 582335.2 & 142829.2 & ICP metals, ${ }^{c}$ mercury, PCBs, and SVOAs \\
\hline $\begin{array}{l}\text { Duplicate of } \\
\text { J16MN5 }\end{array}$ & Soil & J16MN6 & 582344.2 & 142825.6 & ICP metals, ${ }^{c}$ mercury, PCBs, and SVOAs \\
\hline Equipment blank & Silica sand & $\mathrm{J} 16 \mathrm{MM} 7$ & N/A & N/A & ICP metals ${ }^{c}$ and mercury \\
\hline
\end{tabular}

${ }^{a}$ Source: Field logbook EFL-1174-4, pp. 88-89 (WCH 2008a).

b Washington State Plane (meters).

${ }^{\mathrm{c}}$ The expanded list of ICP metals was performed to include arsenic, antimony, barium, beryllium, boron, cadmium, chromium (total), cobalt, copper, lead, manganese, molybdenum, nickel, selenium, silver, vanadium, and zinc in the analytical results package.

ICP = inductively coupled plasma

$\mathrm{N} / \mathrm{A}=$ not applicable

PCB = polychlorinated biphenyl

SVOA $=$ semivolatile organic analysis

\section{Verification Sampling Results}

Verification samples were analyzed using EPA-approved analytical methods. The 95\% upper confidence limits on the true population means for residual concentrations of COCs and COPCs were calculated for the 600-111 septic system remediation as specified by the RDR/RAWP (DOE-RL 2005b), with calculations provided in Appendix C. When a nonradionuclide COC or COPC was detected in fewer than $50 \%$ of the verification samples collected for the area, the maximum detected value was used for comparison to RAGs. If no detections for a given $\mathrm{COC} / \mathrm{COPC}$ were reported in the data set, then no statistical evaluation or calculations were performed for that COC/COPC. Contaminants that were not detected by laboratory analysis are excluded from these tables. Calculated cleanup levels are not presented in the Cleanup Levels and Risk Calculations Database (Ecology 2005) under WAC 173-340-740(3) for aluminum, calcium, iron, magnesium, potassium, silicon, and sodium; therefore, these constituents are not considered site COCs/COPCs.

Comparisons of the statistical and maximum results for COCs and COPCs against the site RAGs are summarized in Table 8. The laboratory-reported data results for all constituents are stored in the ENRE project-specific database prior to provision to HEIS and are presented as an attachment to the statistical calculations in Appendix C. 
Table 8. Comparison of Maximum or Statistical Contaminant Concentrations to Action Levels for the 600-111 Septic System Verification Sampling.

\begin{tabular}{|c|c|c|c|c|c|c|}
\hline \multirow[b]{2}{*}{$\mathrm{COC} / \mathrm{COPCs}$} & \multirow{2}{*}{$\begin{array}{c}\text { Maximum } \\
\text { or } \\
\text { Statistical } \\
\text { Result } \\
\text { (mg/kg) }\end{array}$} & \multicolumn{3}{|c|}{ Remedial Action Goals ${ }^{\mathrm{a}}$ (mg/kg) } & \multirow[b]{2}{*}{$\begin{array}{l}\text { Does the } \\
\text { Result } \\
\text { Exceed } \\
\text { RAGs? }\end{array}$} & \multirow[b]{2}{*}{$\begin{array}{c}\text { Does the } \\
\text { Result Pass } \\
\text { RESRAD } \\
\text { Modeling? }\end{array}$} \\
\hline & & $\begin{array}{c}\text { Direct } \\
\text { Exposure }\end{array}$ & $\begin{array}{l}\text { Soil Cleanup } \\
\text { Level for } \\
\text { Groundwater } \\
\text { Protection }\end{array}$ & $\begin{array}{c}\text { Soil Cleanup } \\
\text { Level for } \\
\text { River } \\
\text { Protection }\end{array}$ & & \\
\hline Antimony & $1.2(<\mathrm{BG})$ & 32 & $5^{b}$ & $5^{b}$ & No & -- \\
\hline Arsenic & $5.6(<\mathrm{BG})$ & 20 & 20 & 20 & No & -- \\
\hline Barium & 154 & 5,600 & $132^{b}$ & 224 & Yes & Yes $^{c}$ \\
\hline Beryllium & $0.97(<\mathrm{BG})$ & $10.4^{\mathrm{d}}$ & $1.51^{\mathrm{b}}$ & $1.51^{\mathrm{b}}$ & No & -- \\
\hline Boron $^{e}$ & 1.2 & 16,000 & 320 & NA & No & \\
\hline Chromium (total) & $11.6(<\mathrm{BG})$ & 80,000 & 18.5 & 18.5 & No & -- \\
\hline Cobalt & $10.6(<\mathrm{BG})$ & 1,600 & 32 & NA & No & -- \\
\hline Copper & 22.8 & 2,960 & 59.2 & $22.0^{b}$ & Yes & Yes $^{c}$ \\
\hline Lead & 12.7 & 353 & $10.2^{b}$ & $10.2^{\mathrm{b}}$ & Yes & Yes $^{c}$ \\
\hline Manganese & $501(<\mathrm{BG})$ & 11,200 & $512^{b}$ & $512^{b}$ & No & -- \\
\hline Mercury & $0.030(<\mathrm{BG})$ & 24 & $0.33^{b}$ & $0.33^{\mathrm{b}}$ & No & -- \\
\hline Molybdenum $^{\mathrm{e}}$ & 1.0 & 400 & 8 & NA & No & -- \\
\hline Nickel & $14.5(<\mathrm{BG})$ & 1,600 & $19.1^{\mathrm{b}}$ & 27.4 & No & - \\
\hline Vanadium & $75.9(<\mathrm{BG})$ & 560 & $85.1^{\mathrm{b}}$ & NA & No & - \\
\hline Zinc & $61.6(<\mathrm{BG})$ & 24,000 & 480 & $67.8^{b}$ & No & - \\
\hline Bis(2-ethylhexyl) phthalate & 0.088 & 71.4 & 0.625 & 0.36 & No & - \\
\hline Isophorone & 0.020 & 1,050 & 9.21 & 1.68 & No & -- \\
\hline Pyrene & 0.018 & 2,400 & 48 & 192 & No & -- \\
\hline
\end{tabular}

a Lookup values and RAGs obtained from the Remedial Design Report/Remedial Action Work Plan for the 100 Area (RDR/RAWP) (DOE-RL 2005) or calculated per WAC-173-340-720, WAC 173-340-730, and WAC 173-340-740, Method B, 1996, unless otherwise noted.

b Where cleanup levels are less than background, cleanup levels default to background (WAC 173-340-700[4][d], 1996).

c RESRAD modeling predicts that compounds having a $\mathrm{K}_{\mathrm{d}}$ greater than $14 \mathrm{~mL} / \mathrm{g}$ will not migrate through the $5.8 \mathrm{~m}(19.0-\mathrm{ft}-)$ thick vadose zone between the shallow zone and groundwater at this site (BHI 2005). The COPCs that failed groundwater and river protection RAGs at the 600-111 waste site have $\mathrm{K}_{\mathrm{d}}$ values of greater than $14 \mathrm{~mL} / \mathrm{g}$ (copper has the lowest $\mathrm{K}_{\mathrm{d}}$ at $22 \mathrm{mg} / \mathrm{kg}$ ) and are not predicted to reach groundwater or the Columbia River within 1,000 years.

${ }^{d}$ Carcinogenic cleanup level calculated based on the inhalation exposure pathway (WAC 173-340-750[3], 1996) using an airborne particulate mass-loading rate of $0.0001 \mathrm{~g} / \mathrm{m}^{3}$ (WDOH 1997).

e No Hanford Site-specific or Washington State background value available.

- $\quad$ = not applicable

$\mathrm{BG} \quad=$ background

$\mathrm{COC}=$ contaminant of concern

COPC = contaminant of potential concern

NA $\quad=$ not available

RAG = remedial action goal

RDL = required detection limit

RESRAD = RESidual RADioactivity (dose assessment model)

WAC = Washington Administrative Code 


\section{VERIFICATION SAMPLE DATA EVALUATION}

Evaluation of the verification sampling results in Table 8 show that all direct exposure and groundwater protection cleanup levels are met for the 600-111 remediated septic system. Barium and lead exceeded groundwater protection RAGs. Copper and lead exceeded Columbia River protection RAGs. Data were not collected on the vertical extent of residual contamination, but RESRAD modeling predicts that compounds having a soil-partitioning coefficient $\left(\mathrm{K}_{\mathrm{d}}\right)$ greater than $14 \mathrm{~mL} / \mathrm{g}$ will not migrate through the $5.8 \mathrm{~m}$ (19.0-ft-) thick vadose zone between the base of the excavation and groundwater at the site (BHI 2005). Barium, lead, and copper all have $K_{d}$ values greater than $14 \mathrm{~mL} / \mathrm{g}$ (copper has the lowest $\mathrm{K}_{\mathrm{d}}$ at $22 \mathrm{~mL} / \mathrm{g}$ ) and are not predicted to reach groundwater or the Columbia River within 1,000 years. Therefore, the remediation of the septic system at the 600-111 waste site is protective of groundwater and the Columbia River. All other COPCs/COCs were either not detected or were quantified below RAGs.

When using a statistical sampling approach, a RAG requirement for nonradionuclides is the WAC 173-340-740(7)(e) three-part test. The WAC 173-340 three-part test consists of the following criteria: (1) the cleanup verification $95 \%$ upper confidence limit value must be less than the cleanup level, (2) no single detection can exceed two times the cleanup criteria, and (3) the percentage of samples exceeding the cleanup criteria must be less than $10 \%$ of the data set.

The application of the three-part test for the septic system at the 600-111 waste site is included in the statistical calculations (Appendix C). The results of this evaluation indicate that all residual $\mathrm{COC} / \mathrm{COPC}$ concentrations pass the three-part test with the exception of barium, copper, lead, and manganese that have greater than $10 \%$ of the data exceeding the groundwater protection and/or river protection RAGs, thus failing the third criterion of the three-part test. A single result of $21.4 \mathrm{mg} / \mathrm{kg}$ for lead exceeded the groundwater and river protection RAGs of $10.2 \mathrm{mg} / \mathrm{kg}$, resulting in failing the second criterion of the three-part test. However, as previously stated, RESRAD modeling predicts that compounds having a $\mathrm{K}_{\mathrm{d}}$ greater than $14 \mathrm{~mL} / \mathrm{g}$ will not migrate through the $5.8 \mathrm{~m}(19.0-\mathrm{ft}-)$ thick vadose between the base of the excavation and groundwater at the site (BHI 2005). Therefore, these constituents are not predicted to migrate to groundwater within 1,000 years and residual concentrations are protective of groundwater and the Columbia River.

Assessment of the risk requirements for the 600-111 waste site was determined by calculation of the hazard quotient and carcinogenic (excess cancer) risk values for nonradionuclides. These calculations are located in Appendix C. The requirements include an individual hazard quotient of less than 1.0, a cumulative hazard quotient of less than 1.0, an individual contaminant carcinogenic risk of less than $1 \times 10^{-6}$, and a cumulative excess carcinogenic risk of less than $1 \times 10^{-5}$. These risk values were conservatively calculated for the entire waste site using the highest values from each of the sampling areas. Risk values were not calculated for constituents that were not detected or were detected at concentrations below Hanford Site or Washington State background values. The calculations indicated that all individual hazard quotients for noncarcinogenic constituents are less than 1.0. The cumulative hazard quotient for the 600-111 waste site is $6.6 \times 10^{-2}$. All individual cumulative carcinogenic risk values are less than $1 \times 10^{-6}$. The cumulative carcinogenic risk value is $1.3 \times 10^{-9}$. Therefore, nonradionuclide risk requirements are met. 


\section{DATA QUALITY ASSESSMENT}

A DQA review was performed to compare the confirmatory and verification sampling approaches and resulting analytical data with the sampling and data requirements specified by the project objectives and performance specifications. The DQA for the 600-111 and UPR-600-16 waste sites established that the data are of the right type, quality, and quantity to support site verification decisions with specified error tolerances. All analytical data were found to be acceptable for decision-making purposes. The evaluation verified that the sample design was sufficient for the purpose of clean site verification. The detailed DQA is presented in Appendix B.

\section{SUMMARY FOR INTERIM CLOSURE}

The UPR-600-16 and 600-111 waste sites have been evaluated and remediated in accordance with the Remaining Sites ROD (EPA 1999) and the RDR/RAWP (DOE-RL 2005b). Confirmatory sampling results for Areas 1,2, and 3 and radiological surveys performed at the UPR-600-16 waste site supported no action. Only the septic system (tank, drain field, and interconnecting pipeline) required remediation with approximately $2,755 \mathrm{~m}^{3}\left(3,603 \mathrm{yd}^{3}\right)$ of material removed and disposed at the Environmental Restoration Disposal Facility. Statistical sampling to verify the completeness of remediation was performed, and analytical results were shown to meet the cleanup objectives for direct exposure, groundwater protection, and river protection. Accordingly, an interim closure reclassification is supported for 600-111 and UPR-600-16 waste sites. The site does not have a deep zone or residual contaminant concentrations that would require any institutional controls.

\section{REFERENCES}

40 CFR 141, "National Primary Drinking Water Regulations," Code of Federal Regulations, as amended.

ANL, 2002, RESRAD for Windows, Version 6.21, Argonne National Laboratory, Environmental Assessment Division, Argonne, Illinois.

ARH, 1974, P-11 Facility Cleanup Summary Report, ARH-ST-106, Atlantic Richfield Hanford Company, Richland, Washington.

BHI, 2001, Calculation of Total Uranium Activity Corresponding to a Maximum Contaminant Level of 30 Micrograms per Liter in Groundwater, 0100X-CA-V0038, Rev. 0, Bechtel Hanford, Inc., Richland, Washington.

BHI, 2003, Remaining Sites Field Sampling Logbook, EL-1578-1, pp. 98-100, Bechtel Hanford, Inc., Richland, Washington. 
BHI, 2004a, 600-111, P-11 Critical Mass Laboratory RESRAD Calculation Brief, 0600X-CAV0043, Rev. 0, Bechtel Hanford, Inc., Richland, Washington.

BHI, 2004b, Remaining Sites Field Sampling Logbook, EL-1578-2, pp. 2, 3, 7-11, 12, 13, Bechtel Hanford, Inc., Richland, Washington.

BHI, 2004c, Results of Geophysical Investigation at Remaining Sites 600-5, 600-100, 600-111/UPR-600-116, 600-109, 600-110, 600-120, 600-124, 600-125, 600-127, and 600-188, CCN 112476, Bechtel Hanford, Inc., Richland, Washington.

BHI, 2004d, Work Instruction for Waste Site 600-111, P-11 Critical Mass Laboratory Crib and Waste Site UPR-600-16, Fire and Contamination Spread, 0600X-WI-G0004, Rev. 0, Bechtel Hanford, Inc., Richland, Washington.

BHI, 2005, 100 Area Analogous Sites RESRAD Calculations, 0100X-CA-V0050, Rev. 0, Bechtel Hanford, Inc., Richland, Washington.

BHI-EE-01, Environmental Investigation Procedures, Bechtel Hanford, Inc., Richland, Washington.

Comprehensive Environmental Response, Compensation, and Liability Act of 1980, 42 U.S.C. 9601, et seq.

DOE Order 5400.5, Radiation Protection of the Public and the Environment, as amended, U.S. Department of Energy, Washington, D.C.

DOE-RL, 2000, Sampling and Analysis Plan for the 100 Area Remaining Sites, DOE/RL-99-58, Rev. 0, U.S. Department of Energy, Richland Operations Office, Richland, Washington.

DOE-RL, 2007, Tri-Party Agreement Handbook Management Procedures, RL-TPA-90-0001, Guideline Number TPA-MP-14, "Maintenance of the Waste Information Data System (WIDS)," Rev. 1, U.S. Department of Energy, Richland Operations Office, Richland, Washington.

DOE-RL, 2005a, 100 Area Remedial Action Sampling and Analysis Plan, DOE/L-96-22, Rev. 4, U.S. Department of Energy, Richland Operations Office, Richland, Washington.

DOE-RL, 2005b, Remedial Design Report/Remedial Action Work Plan for the 100 Areas, DOE/RL-96-17, Rev. 5, U.S. Department of Energy, Richland Operations Office, Richland, Washington.

Ecology, 1995, Guidance on Sampling and Data Analysis Methods, Publication No. 94-49, Washington State Department of Ecology, Olympia, Washington. 
Ecology, 2005, Cleanup Levels and Risk Calculations (CLARC) Database, Washington State Department of Ecology, Olympia, Washington, $<$ https://fortress.wa.gov/ecy/clarc/CLARCHome.aspx>.

ENV-1-2, Environmental Monitoring \& Management, Part II, Environmental Investigations, Requests, and Field Screening, Washington Closure Hanford, Richland, Washington.

EPA, 1999, Interim Action Record of Decision for the 100-BC-1, 100-BC-2, 100-DR-1, 100-DR-2, 100-FR-1, 100-FR-2, 100-HR-1, 100-HR-2, 100-KR-1, 100-KR-2, 100-IU-2, 100-IU-6, and 200-CW-3 Operable Units, Hanford Site, Benton County, Washington, U.S. Environmental Protection Agency, Washington, D.C.

Gilbert, R. O., 1987, Statistical Methods for Environmental Pollution Monitoring, Wiley \& Sons, Inc., New York, New York.

WAC 173-303, "Dangerous Waste Regulations," Washington Administrative Code, as amended.

WAC 173-340, "Model Toxics Control Act-Cleanup," Washington Administrative Code, 1996.

WCH, 2008a, 100-F Area RAWD Sampling Logbook, EL-1174-4, pp. 97, 98, Washington Closure Hanford, Richland, Washington.

WCH, 2008b, Work Instruction for Verification Sampling of the 600-111 Septic Tank and Drain Field (600-111), 0600X-WI-G0015, Rev. 0, Washington Closure Hanford, Richland, Washington.

WDOH, 1997, Hanford Guidance for Radiological Cleanup, WDOH/320-015, Rev. 1, Division of Radiation Protection, Washington State Department of Health, Olympia, Washington. 


\section{APPENDIX A}

\section{0-111 DATA SUMMARY TABLES}


Table A-1. 600-111 Inorganic Data Summary. (2 pages)

\begin{tabular}{|c|c|c|c|c|c|c|c|c|c|c|c|c|c|c|c|c|c|c|c|c|}
\hline \multirow{2}{*}{ Sample Area } & \multirow{2}{*}{$\begin{array}{c}\text { HEIS } \\
\text { Number }\end{array}$} & \multirow{2}{*}{$\begin{array}{c}\text { Sample } \\
\text { Date }\end{array}$} & \multicolumn{3}{|c|}{ Aluminum } & \multicolumn{3}{|c|}{ Antimony } & \multicolumn{3}{|c|}{ Arsenic } & \multicolumn{3}{|c|}{ Barium } & \multicolumn{3}{|c|}{ Beryllium } & \multicolumn{3}{|c|}{ Boron } \\
\hline & & & $\mathrm{mg} / \mathrm{kg}$ & Q & PQL & $\mathrm{mg} / \mathrm{kg}$ & Q & PQL & $\mathrm{mg} / \mathrm{kg}$ & $\mathbf{Q}$ & PQL & $\mathrm{mg} / \mathrm{kg}$ & $\mathbf{Q}$ & PQL & $\mathrm{mg} / \mathrm{kg}$ & $\mathbf{Q}$ & PQL & $\mathrm{mg} / \mathrm{kg}$ & $\mathbf{Q}$ & PQL \\
\hline Equipment Blank & $\mathrm{J} 01 \mathrm{~F} 82$ & $04 / 29 / 04$ & 34.3 & & 2.7 & 0.21 & $\mathrm{U}$ & 0.21 & 0.32 & & 0.27 & 0.96 & & 0.02 & 0.02 & $\mathrm{U}$ & 0.02 & 0.59 & & 0.16 \\
\hline Septic Tank (Area 6) & J01F83 & $04 / 29 / 04$ & 8320 & & 4.7 & 0.37 & $\mathrm{U}$ & 0.37 & 15.7 & & 0.47 & 291 & & 0.03 & 0.63 & & 0.03 & 3 & & 0.28 \\
\hline Drain Field (Area 5) & J01F84 & $04 / 29 / 04$ & 7820 & & 4.9 & 2 & & 0.38 & 43.8 & & 0.48 & 3340 & & 0.03 & 0.45 & & 0.03 & 4.1 & & 0.28 \\
\hline 123 Bldg. (Area 3) & J01F85 & $05 / 05 / 04$ & 5830 & & 3 & 0.23 & $\mathrm{U}$ & 0.23 & 19.7 & & 0.29 & 117 & & 0.02 & 0.48 & & 0.02 & 2.7 & & 0.29 \\
\hline 120 Bldg. (Area 1) & J01F70 & $05 / 05 / 04$ & 10800 & & 3.7 & 0.29 & $\mathrm{U}$ & 0.29 & 7.5 & & 0.36 & 138 & & 0.02 & 0.66 & & 0.02 & 0.95 & & 0.21 \\
\hline Crib (Area 2) & J01F71 & 05/10/04 & 7260 & & 2.6 & 0.2 & $\mathrm{U}$ & 0.2 & 8.7 & & 0.26 & 102 & & 0.02 & 0.29 & & 0.02 & 1.5 & & 0.145 \\
\hline $\begin{array}{c}\text { Duplicate } \\
\text { (Crib) }\end{array}$ & $\mathrm{J} 01 \mathrm{~F} 72$ & 05/10/04 & 6780 & & 3.4 & 0.27 & $\mathrm{U}$ & 0.27 & 8.3 & & 0.34 & 92.4 & & 0.02 & 0.24 & & 0.02 & 1.3 & & 0.2 \\
\hline
\end{tabular}

\begin{tabular}{|c|c|c|c|c|c|c|c|c|c|c|c|c|c|c|c|c|c|c|c|c|}
\hline \multirow{2}{*}{ Sample Area } & \multirow{2}{*}{$\begin{array}{c}\text { HEIS } \\
\text { Number }\end{array}$} & \multirow{2}{*}{$\begin{array}{c}\text { Sample } \\
\text { Date }\end{array}$} & \multicolumn{3}{|c|}{ Cadmium } & \multicolumn{3}{|c|}{ Calcium } & \multicolumn{3}{|c|}{ Chromium } & \multicolumn{3}{|c|}{ Cobalt } & \multicolumn{3}{|c|}{ Copper } & \multicolumn{3}{|c|}{ Iron } \\
\hline & & & $\mathrm{mg} / \mathrm{kg}$ & $\mathbf{Q}$ & PQL & $\mathrm{mg} / \mathrm{kg}$ & $\mathbf{Q}$ & PQL & $\mathrm{mg} / \mathrm{kg}$ & $\mathbf{Q}$ & PQL & $\mathrm{mg} / \mathrm{kg}$ & $\mathbf{Q}$ & PQL & $\mathrm{mg} / \mathrm{kg}$ & $\mathbf{Q}$ & PQL & $\mathrm{mg} / \mathrm{kg}$ & $\mathbf{Q}$ & PQL \\
\hline Equipment Blank & J0IF82 & 04/29/04 & 0.03 & $\mathrm{U}$ & 0.03 & 20.6 & & 1.6 & 0.12 & & 0.04 & 0.05 & $\mathrm{U}$ & 0.05 & 0.09 & $\mathrm{U}$ & 0.09 & 344 & & 0.87 \\
\hline Septic Tank (Area 6) & J01F83 & $04 / 29 / 04$ & 2.7 & & 0.06 & 7980 & & 2.8 & 14.6 & & 0.07 & 8.4 & & 0.08 & 92.4 & & 0.17 & 45200 & & 1.5 \\
\hline Drain Field (Area 5) & J01F84 & $04 / 29 / 04$ & 20.4 & & 0.06 & 7050 & & 2.9 & 40.2 & & 0.07 & 6.9 & & 0.09 & 466 & & 0.17 & 34300 & & 1.6 \\
\hline 123 Bldg. (Area 3) & J01F85 & $05 / 05 / 04$ & 0.27 & & 0.03 & 8400 & & 1.8 & 11.9 & & 0.04 & 6.8 & & 0.05 & 39.6 & & 0.1 & 20900 & & 0.95 \\
\hline 120 Bldg. (Area 1) & $\mathrm{J} 01 \mathrm{~F} 70$ & $05 / 05 / 04$ & 0.36 & & 0.04 & 7400 & & 2.2 & 17.9 & & 0.05 & 9.7 & & 0.06 & 29.1 & & 0.13 & 23900 & & 1.2 \\
\hline Crib (Area 2) & J01F71 & $05 / 10 / 04$ & 0.09 & & 0.03 & 4870 & & 1.6 & 11.8 & & 0.04 & 8.1 & & 0.05 & 16.8 & & 0.09 & 24700 & & 0.83 \\
\hline $\begin{array}{c}\text { Duplicate } \\
\text { (Crib) }\end{array}$ & J01F72 & $05 / 10 / 04$ & 0.17 & & 0.04 & 4970 & & 2.1 & 9.5 & & 0.05 & 7.3 & & 0.06 & 17.4 & & 0.12 & 23700 & & 1.1 \\
\hline
\end{tabular}

\begin{tabular}{|c|c|c|c|c|c|c|c|c|c|c|c|c|c|c|c|c|c|c|c|c|}
\hline \multirow{2}{*}{ Sample Area } & \multirow{2}{*}{$\begin{array}{l}\text { HEIS } \\
\text { Number }\end{array}$} & \multirow{2}{*}{$\begin{array}{c}\text { Sample } \\
\text { Date }\end{array}$} & \multicolumn{3}{|c|}{ Lead } & \multicolumn{3}{|c|}{ Magnesium } & \multicolumn{3}{|c|}{ Manganese } & \multicolumn{3}{|c|}{ Mercury } & \multicolumn{3}{|c|}{ Molybdenum } & \multicolumn{3}{|c|}{ Nickel } \\
\hline & & & $\mathrm{mg} / \mathrm{kg}$ & $\mathbf{Q}$ & PQL & $\mathrm{mg} / \mathrm{kg}$ & Q & PQL & $\mathrm{mg} / \mathrm{kg}$ & $\mathbf{Q}$ & PQL & $\mathrm{mg} / \mathrm{kg}$ & $\mathbf{Q}$ & PQL & $\mathrm{mg} / \mathrm{kg}$ & $\mathbf{Q}$ & PQL & $\mathrm{mg} / \mathrm{kg}$ & $\mathbf{Q}$ & PQL \\
\hline Equipment Blank & J01F82 & $04 / 29 / 04$ & 0.34 & & 0.16 & 6.4 & & 0.31 & 4.3 & & 0.008 & 0.01 & $\mathrm{U}$ & 0.01 & 0.21 & & 0.14 & 0.08 & $\mathrm{U}$ & 0.08 \\
\hline Septic Tank (Area 6) & $\mathrm{J} 01 \mathrm{~F} 83$ & $04 / 29 / 04$ & 81.1 & & 0.28 & 5120 & & 0.54 & 397 & & 0.01 & 0.6 & & 0.03 & 5.6 & & 0.25 & 17 & & 0.14 \\
\hline Drain Field (Area 5) & J01F84 & $04 / 29 / 04$ & 1100 & & 0.28 & 4440 & & 0.55 & 552 & & 0.01 & 5 & & 0.24 & 21.1 & & 0.26 & 18 & & 0.14 \\
\hline 123 Bldg. (Area 3) & J01F85 & $05 / 05 / 04$ & 142 & & 0.17 & 4030 & & 0.34 & 353 & & 0.009 & 0.02 & $\mathrm{U}$ & 0.02 & 0.66 & & 0.16 & 11 & & 0.09 \\
\hline 120 Bldg. (Area 1) & J01F70 & $05 / 05 / 04$ & 11.3 & & 0.21 & 7110 & & 0.42 & 441 & & 0.01 & 0.02 & & 0.02 & 0.27 & & 0.19 & 23.6 & & 0.11 \\
\hline Crib (Area 2) & $\mathrm{J} 01 \mathrm{~F} 71$ & $05 / 10 / 04$ & 18.6 & & 0.15 & 5000 & & 0.29 & 378 & & 0.008 & 0.01 & $\mathrm{U}$ & 0.01 & 0.54 & & 0.14 & 15.4 & & 0.08 \\
\hline $\begin{array}{c}\text { Duplicate } \\
\text { (Crib) }\end{array}$ & J01F72 & $05 / 10 / 04$ & 19.4 & & 0.2 & 4580 & & 0.39 & 346 & & 0.01 & 0.02 & $\mathrm{U}$ & 0.02 & 0.47 & & 0.18 & 11.3 & & 0.1 \\
\hline
\end{tabular}

HEIS = Hanford Environmental Information System

$\mathrm{PQL}=$ practical quantitation limit

Q = qualifier

D $\quad \mathrm{U} \quad=$ undetected 
Table A-1. 600-111 Inorganic Data Summary. (2 pages)

\begin{tabular}{|c|c|c|c|c|c|c|c|c|c|c|c|c|c|c|c|c|c|c|c|c|}
\hline \multirow{2}{*}{ Sample Area } & \multirow{2}{*}{$\begin{array}{l}\text { HEIS } \\
\text { Number }\end{array}$} & \multirow{2}{*}{$\begin{array}{c}\text { Sample } \\
\text { Date }\end{array}$} & \multicolumn{3}{|c|}{ Potassium } & \multicolumn{3}{|c|}{ Selenium } & \multicolumn{3}{|c|}{ Silicon } & \multicolumn{3}{|c|}{ Silver } & \multicolumn{3}{|c|}{ Sodium } & \multicolumn{3}{|c|}{ Vanadium } \\
\hline & & & $\mathrm{mg} / \mathrm{kg}$ & $\mathbf{Q}$ & PQL & $\mathrm{mg} / \mathrm{kg}$ & $\mathbf{Q}$ & PQL & $\mathrm{mg} / \mathrm{kg}$ & $\mathbf{Q}$ & PQL & $\mathrm{mg} / \mathrm{kg}$ & $\mathbf{Q}$ & PQL & $\mathrm{mg} / \mathrm{kg}$ & $\mathbf{Q}$ & PQL & $\mathrm{mg} / \mathrm{kg}$ & $\mathbf{Q}$ & PQL \\
\hline Equipment Blank & J01F82 & $04 / 29 / 04$ & 129 & & 0.83 & 0.27 & $\mathrm{U}$ & 0.27 & 26.5 & & 0.66 & 0.05 & $\mathrm{U}$ & 0.05 & 6.7 & & 0.11 & 0.18 & & 0.04 \\
\hline Septic Tank (Area 6) & J01F83 & $04 / 29 / 04$ & 2170 & & 1.5 & 0.49 & & 0.47 & 554 & & 1.2 & 1.9 & & 0.08 & 235 & & 0.19 & 79.8 & & 0.07 \\
\hline Drain Field (Area 5) & J01F84 & $04 / 29 / 04$ & 2270 & & 1.5 & 6.5 & & 0.48 & 417 & & 1.2 & 11.5 & & 0.09 & 356 & & 0.2 & 158 & & 0.07 \\
\hline 123 Bldg. (Area 3) & J01F85 & $05 / 05 / 04$ & 1710 & & 0.92 & 0.29 & $\mathrm{U}$ & 0.29 & 200 & & 0.73 & 0.05 & $\mathrm{U}$ & 0.05 & 355 & & 0.12 & 44.9 & & 0.04 \\
\hline 120 Bldg. (Area 1) & $\mathrm{J} 01 \mathrm{~F} 70$ & $05 / 05 / 04$ & 1880 & & 1.1 & 0.36 & $\mathrm{U}$ & 0.36 & 268 & & 0.9 & 0.06 & $\mathrm{U}$ & 0.06 & 239 & & 0.15 & 51.3 & & 0.05 \\
\hline Crib (Area 2) & J01F71 & $05 / 10 / 04$ & 1350 & & 0.8 & 0.29 & & 0.26 & 319 & & 0.63 & 0.05 & $\mathrm{U}$ & 0.05 & 170 & & 0.11 & 58.5 & & 0.04 \\
\hline $\begin{array}{l}\text { Duplicate } \\
\text { (Crib) }\end{array}$ & J01F72 & $05 / 10 / 04$ & 1340 & & 1.1 & 0.34 & $\mathrm{U}$ & 0.34 & 438 & & 0.84 & 0.06 & $\mathrm{U}$ & 0.06 & 160 & & 0.14 & 60.4 & & 0.05 \\
\hline
\end{tabular}

\section{Table A-2. 600-111 Asbestos Data.}

\begin{tabular}{|c|c|c|c|c|c|}
\hline \multirow{2}{*}{ Sample Area } & \multirow{2}{*}{$\begin{array}{c}\text { HEIS } \\
\text { Number }\end{array}$} & \multirow{2}{*}{$\begin{array}{c}\text { Sample } \\
\text { Date }\end{array}$} & \multicolumn{3}{|c|}{ Zinc } \\
\hline & & & $\mathrm{mg} / \mathrm{kg}$ & Q & $\mathrm{PQL}$ \\
\hline Equipment Blank & J01F82 & 04/29/04 & 0.94 & & 0.03 \\
\hline Septic Tank (Area 6) & J01F83 & $04 / 29 / 04$ & 578 & & 0.06 \\
\hline Drain Field (Area 5) & J01F84 & $04 / 29 / 04$ & 5190 & & 0.68 \\
\hline 123 Bldg. (Area 3) & J01F85 & $05 / 05 / 04$ & 177 & & 0.03 \\
\hline $120 \mathrm{Bldg}$. (Area 1) & J01F70 & $05 / 05 / 04$ & 60 & & 0.04 \\
\hline Crib (Area 2) & J01F71 & $05 / 10 / 04$ & 49.2 & & 0.03 \\
\hline $\begin{array}{c}\text { Duplicate } \\
\text { (Crib) }\end{array}$ & J01F72 & 05/10/04 & 49.1 & & 0.04 \\
\hline
\end{tabular}

\begin{tabular}{|c|c|c|c|}
\hline Sample Area & $\begin{array}{c}\text { HEIS } \\
\text { Number }\end{array}$ & $\begin{array}{c}\text { Sample } \\
\text { Date }\end{array}$ & Asbestos \\
\hline $\begin{array}{c}\text { Septic } \\
\text { Tank Pipe } \\
\text { (tar paper) }\end{array}$ & J01C01 & $09 / 04 / 04$ & Non detected \\
\hline
\end{tabular}

Table A-3. TCLP Metals Data.

\begin{tabular}{|c|c|c|c|c|c|c|c|c|c|c|c|c|c|c|c|c|c|c|c|c|}
\hline \multirow{2}{*}{ Sample Area } & \multirow{2}{*}{\begin{tabular}{|c|} 
HEIS \\
Number \\
\end{tabular}} & \multirow{2}{*}{$\begin{array}{c}\text { Sample } \\
\text { Date }\end{array}$} & \multicolumn{3}{|c|}{ Arsenic } & \multicolumn{3}{|c|}{ Barium } & \multicolumn{3}{|c|}{ Cadmium } & \multicolumn{3}{|c|}{ Chromium } & \multicolumn{3}{|c|}{ Lead } & \multicolumn{3}{|c|}{ Mercury } \\
\hline & & & $\mu \mathrm{g} / \mathrm{mL}$ & $\mathbf{Q}$ & PQL & $\mu \mathrm{g} / \mathrm{mL}$ & $Q$ & PQL & $\mu \mathrm{g} / \mathrm{mL}$ & $\mathbf{Q}$ & PQL & $\mu \mathrm{g} / \mathrm{mL}$ & $\mathbf{Q}$ & PQL & $\mu \mathrm{g} / \mathrm{mL}$ & $\mathbf{Q}$ & PQL & $\mu \mathrm{g} / \mathrm{mL}$ & $\mathbf{Q}$ & PQL \\
\hline $\begin{array}{c}\text { Drain Field } \\
\text { (Area 5) }\end{array}$ & J01F84 & $04 / 29 / 04$ & 28 & & 20.4 & 159 & & 1.2 & 102 & & 2.4 & 3.2 & & 3 & 99.2 & & 12 & 0.25 & & 0.2 \\
\hline
\end{tabular}

\begin{tabular}{|c|c|c|c|c|c|c|c|c|}
\hline \multirow{2}{*}{ Sample Area } & HEIS & Sample & \multicolumn{3}{|c|}{ Selenium } & \multicolumn{3}{c|}{ Silver } \\
\cline { 4 - 9 } & Number & Date & $\mu \mathrm{g} / \mathrm{mL}$ & $\mathrm{Q}$ & $\mathrm{PQL}$ & $\mu \mathrm{g} / \mathrm{mL}$ & $\mathrm{Q}$ & PQL \\
\hline $\begin{array}{c}\text { Drain Field } \\
\text { (Area 5) }\end{array}$ & $\mathrm{J} 01 \mathrm{~F} 84$ & $04 / 29 / 04$ & 20.4 & $\mathrm{U}$ & 20.4 & 3.6 & $\mathrm{U}$ & 3.6 \\
\hline
\end{tabular}

$\begin{array}{llll}\text { GEA } & =\text { gamma energy analysis } & \text { Q } & =\text { qualifier } \\ \text { HEIS } & =\text { Hanford Environmental Information System } & \text { SVOA } & =\text { semivolatile organic analyses } \\ \text { J } & =\text { estimated } & \text { TCLP } & =\text { toxicity characteristic leaching procedure } \\ \text { MDA } & =\text { minimum detectable activity } & \mathrm{U} & =\text { undetected } \\ \text { PCB } & =\text { polychlorinated biphenyl } & & \end{array}$

$\mathrm{PCB}=$ polychlorinated biphenyl

PQL = practical quantitation limit 
Table A-4. 600-111 Radionuclide Data Summary.

\begin{tabular}{|c|c|c|c|c|c|c|c|c|c|c|c|c|c|c|c|c|c|c|c|c|}
\hline \multirow{2}{*}{ Sample Area } & \multirow{2}{*}{$\begin{array}{c}\text { HEIS } \\
\text { Number }\end{array}$} & \multirow{2}{*}{$\begin{array}{c}\text { Sample } \\
\text { Date }\end{array}$} & \multicolumn{3}{|c|}{ Americium-241 } & \multicolumn{3}{|c|}{ Americium-241 GEA } & \multicolumn{3}{|c|}{ Cesium-137 } & \multicolumn{3}{|c|}{ Cobalt-60 } & \multicolumn{3}{|c|}{ Europium-152 } & \multicolumn{3}{|c|}{ Europium-154 } \\
\hline & & & $\mathrm{pCi} / \mathrm{g}$ & $Q$ & MDA & $\mathrm{pCi} / \mathrm{g}$ & $Q$ & MDA & $\mathrm{pCi} / \mathrm{g}$ & $\mathbf{Q}$ & MDA & $\mathrm{pCi} / \mathrm{g}$ & $Q$ & MDA & $\mathrm{pCi} / \mathrm{g}$ & $\mathbf{Q}$ & MDA & $\mathrm{pCi} / \mathrm{g}$ & $Q$ & MDA \\
\hline Equipment Blank & J01F82 & $04 / 29 / 04$ & 0.095 & $\mathrm{U}$ & 0.24 & 0.08 & $\mathrm{U}$ & 0.08 & 0.022 & $\mathrm{U}$ & 0.022 & 0.025 & $\mathrm{U}$ & 0.025 & 0.048 & $\mathrm{U}$ & 0.048 & 0.082 & $\mathrm{U}$ & 0.082 \\
\hline Septic Tank (Area 6) & J01F83 & $04 / 29 / 04$ & 0.03 & $\mathrm{U}$ & 0.23 & 0.076 & $\mathrm{U}$ & 0.076 & 0.018 & $\mathrm{U}$ & 0.018 & 0.019 & $\mathrm{U}$ & 0.019 & 0.045 & $\mathrm{U}$ & 0.045 & 0.059 & $\mathrm{U}$ & 0.059 \\
\hline Drain Field (Area 5) & J01F84 & $04 / 29 / 04$ & -0.026 & $\mathrm{U}$ & 0.2 & 0.36 & $\mathrm{U}$ & 0.36 & 0.14 & $\mathrm{U}$ & 0.14 & 0.13 & $\mathrm{U}$ & 0.13 & 0.32 & $\mathrm{U}$ & 0.32 & 0.4 & $\mathrm{U}$ & 0.4 \\
\hline 123 Bldg. (Area 3) & J01F85 & $05 / 05 / 04$ & 0 & $\mathrm{U}$ & 0.17 & 0.11 & $\mathrm{U}$ & 0.11 & 0.361 & & 0.026 & 0.029 & $\mathrm{U}$ & 0.029 & 0.078 & $\mathrm{U}$ & 0.078 & 0.11 & $\mathrm{U}$ & 0.11 \\
\hline 120 Bldg. (Area 1) & J01F70 & $05 / 05 / 04$ & 0 & $\mathrm{U}$ & 0.17 & 0.19 & $\mathrm{U}$ & 0.19 & 0.025 & $\mathrm{U}$ & 0.025 & 0.027 & $\mathrm{U}$ & 0.027 & 0.061 & $\mathrm{U}$ & 0.061 & 0.081 & $\mathrm{U}$ & 0.081 \\
\hline Crib (Area 2) & J01F71 & $05 / 10 / 04$ & 0.226 & & 0.22 & 0.048 & $\mathrm{U}$ & 0.048 & 0.026 & $\mathrm{U}$ & 0.026 & 0.026 & $\mathrm{U}$ & 0.026 & 0.082 & $\mathrm{U}$ & 0.082 & 0.094 & $\mathrm{U}$ & 0.094 \\
\hline $\begin{array}{c}\text { Duplicate } \\
\text { (Crib) }\end{array}$ & $\mathrm{J} 01 \mathrm{~F} 72$ & $05 / 10 / 04$ & 0.141 & $\mathrm{U}$ & 0.22 & 0.057 & $\mathrm{U}$ & 0.057 & 0.032 & $\mathrm{U}$ & 0.032 & 0.03 & $\mathrm{U}$ & 0.03 & 0.094 & $\mathrm{U}$ & 0.094 & 0.097 & $\mathrm{U}$ & 0.097 \\
\hline
\end{tabular}

\begin{tabular}{|c|c|c|c|c|c|c|c|c|c|c|c|c|c|c|c|c|c|c|c|c|}
\hline \multirow{2}{*}{ Sample Area } & \multirow{2}{*}{$\begin{array}{c}\text { HEIS } \\
\text { Number }\end{array}$} & \multirow{2}{*}{$\begin{array}{c}\text { Sample } \\
\text { Date }\end{array}$} & \multicolumn{3}{|c|}{ Europium-155 } & \multicolumn{3}{|c|}{ Plutonium-238 } & \multicolumn{3}{|c|}{ Plutonium-239/240 } & \multicolumn{3}{|c|}{ Potassium-40 } & \multicolumn{3}{|c|}{ Radium-226 } & \multicolumn{3}{|c|}{ Radium-228 } \\
\hline & & & $\mathrm{pCi} / \mathrm{g}$ & $Q$ & MDA & $\mathrm{pCi} / \mathrm{g}$ & $Q$ & MDA & $\mathrm{pCi} / \mathrm{g}$ & $Q$ & MDA & $\mathrm{pCi} / \mathrm{g}$ & $\mathbf{Q}$ & MDA & pCi/g & $\mathbf{Q}$ & MDA & $\mathrm{pCi} / \mathrm{g}$ & $\mathbf{Q}$ & MDA \\
\hline Equipment Blank & J01F82 & $04 / 29 / 04$ & 0.056 & $\mathrm{U}$ & 0.056 & 0 & $\mathrm{U}$ & 0.4 & 0.103 & $\mathrm{U}$ & 0.4 & 4.84 & & 0.31 & 0.14 & & 0.045 & 0.223 & & 0.11 \\
\hline Septic Tank (Area 6) & J01F83 & $04 / 29 / 04$ & 0.049 & $\mathrm{U}$ & 0.049 & 0 & $\mathrm{U}$ & 0.36 & 0.234 & $\mathrm{U}$ & 0.36 & 6.91 & & 0.18 & 0.256 & & 0.039 & 0.44 & & 0.083 \\
\hline Drain Field (Area 5) & J01F84 & $04 / 29 / 04$ & 0.32 & $\mathrm{U}$ & 0.32 & 0.062 & $\mathrm{U}$ & 0.48 & 0.249 & $\mathrm{U}$ & 0.48 & 5.4 & $\mathrm{U}$ & 5.4 & 0.3 & $\mathrm{U}$ & 0.3 & 0.76 & $\mathrm{U}$ & 0.76 \\
\hline 123 Bldg. (Area 3) & J01F85 & $05 / 05 / 04$ & 0.078 & $\mathrm{U}$ & 0.078 & -0.025 & $\mathrm{U}$ & 0.19 & 0 & $\mathrm{U}$ & 0.19 & 10.5 & & 0.34 & 0.46 & & 0.059 & 0.542 & & 0.16 \\
\hline 120 Bldg. (Area 1) & J01F70 & $05 / 05 / 04$ & 0.085 & $\mathrm{U}$ & 0.085 & 0 & $\mathrm{U}$ & 0.25 & 0.097 & $\mathrm{U}$ & 0.25 & 11.7 & & 0.28 & 0.589 & & 0.055 & 0.814 & & 0.11 \\
\hline Crib (Area 2) & J01F71 & $05 / 10 / 04$ & 0.075 & $\mathrm{U}$ & 0.075 & 0 & $\bar{U}$ & 0.24 & 0.816 & & 0.24 & 9.74 & & 0.25 & 0.355 & & 0.05 & 0.653 & & 0.12 \\
\hline $\begin{array}{c}\text { Duplicate } \\
\text { (Crib) }\end{array}$ & $\mathrm{J} 01 \mathrm{~F} 72$ & $05 / 10 / 04$ & 0.086 & $\mathrm{U}$ & 0.086 & 0.076 & $\mathrm{U}$ & 0.29 & 0.57 & & 0.29 & 10.7 & & 0.24 & 0.356 & & 0.067 & 0.761 & & 0.14 \\
\hline
\end{tabular}

\begin{tabular}{|c|c|c|c|c|c|c|c|c|c|c|c|c|c|c|}
\hline \multirow{2}{*}{ Sample Area } & \multirow{2}{*}{$\begin{array}{c}\text { HEIS } \\
\text { Number }\end{array}$} & \multirow{2}{*}{$\begin{array}{c}\text { Sample } \\
\text { Date }\end{array}$} & \multicolumn{3}{|c|}{ Thorium-228 GEA } & \multicolumn{3}{|c|}{ Thorium-232 GEA } & \multicolumn{3}{|c|}{ Uranium-235 GEA } & \multicolumn{3}{|c|}{ Uranium-238 GEA } \\
\hline & & & pCi/g & $\mathbf{Q}$ & MDA & $\mathrm{pCi} / \mathrm{g}$ & $\mathbf{Q}$ & MDA & pCi/g & $\mathbf{Q}$ & MDA & $\mathrm{pCi} / \mathrm{g}$ & $\mathbf{Q}$ & MDA \\
\hline Equipment Blank & J01F82 & $04 / 29 / 04$ & 0.187 & & 0.025 & 0.223 & & 0.11 & 0.08 & $\mathrm{U}$ & 0.08 & 3.2 & $\mathrm{U}$ & 3.2 \\
\hline Septic Tank (Area 6) & J01F83 & $04 / 29 / 04$ & 0.397 & & 0.022 & 0.44 & & 0.083 & 0.069 & $\mathrm{U}$ & 0.069 & 2.6 & $\mathrm{U}$ & 2.6 \\
\hline Drain Field (Area 5) & J01F84 & $04 / 29 / 04$ & 0.36 & $\mathrm{U}$ & 0.36 & 0.76 & $\mathrm{U}$ & 0.76 & 0.47 & $\mathrm{U}$ & 0.47 & 18 & $\mathrm{U}$ & 18 \\
\hline 123 Bldg. (Area 3) & $\mathrm{J} 01 \mathrm{~F} 85$ & $05 / 05 / 04$ & 0.52 & & 0.034 & 0.542 & & 0.16 & 0.11 & $\mathrm{U}$ & 0.11 & 3.5 & $\mathrm{U}$ & 3.5 \\
\hline 120 Bldg. (Area 1) & J01F70 & $05 / 05 / 04$ & 0.626 & & 0.034 & 0.814 & & 0.11 & 0.11 & $\mathrm{U}$ & 0.11 & 3.3 & $\mathrm{U}$ & 3.3 \\
\hline Crib (Area 2) & J01F71 & $05 / 10 / 04$ & 0.716 & & 0.047 & 0.653 & & 0.12 & 0.12 & $\mathrm{U}$ & 0.12 & 2.9 & $\mathrm{U}$ & 2.9 \\
\hline $\begin{array}{c}\text { Duplicate } \\
\text { (Crib) }\end{array}$ & J01F72 & $05 / 10 / 04$ & 0.639 & & 0.054 & 0.761 & & 0.14 & 0.13 & $\mathrm{U}$ & 0.13 & 3.4 & $\mathrm{U}$ & 3.4 \\
\hline
\end{tabular}

GEA = gamma energy analysis

HEIS = Hanford Environmental Information System

$\mathrm{MDA}=$ minimum detectable activity

$\mathrm{Q} \quad=$ qualifier

$\mathrm{U} \quad=$ undetected 
Table A-5. 600-111 PCB Data Summary.

\begin{tabular}{|c|c|c|c|c|c|c|c|c|c|c|c|c|c|c|c|c|c|c|c|c|c|}
\hline \multirow[t]{2}{*}{ Constituent } & \multicolumn{3}{|c|}{$\begin{array}{c}\text { J01F70 } \\
\text { 120 Bldg (Area 1) } \\
\text { Sample Date } \\
5 / 5 / 04\end{array}$} & \multicolumn{3}{|c|}{$\begin{array}{c}\text { J01F71 } \\
\text { Crib (Area 2) } \\
\text { Sample Date } \\
\text { 5/10/04 }\end{array}$} & \multicolumn{3}{|c|}{$\begin{array}{c}\text { J01F72 } \\
\text { Duplicate (Crib) } \\
\text { Sample Date } \\
\text { 5/10/04 }\end{array}$} & \multicolumn{3}{|c|}{$\begin{array}{c}\text { J01F82 } \\
\text { Equipment Blank } \\
\text { Sample Date 4/29/04 }\end{array}$} & \multicolumn{3}{|c|}{$\begin{array}{c}\text { J01F83 } \\
\text { Septic Tank (Area 6) } \\
\text { Sample Date } \\
4 / 29 / 04 \\
\end{array}$} & \multicolumn{3}{|c|}{\begin{tabular}{|c|} 
J01F84 \\
Septic Drain Field (Area \\
5) \\
Sample Date 4/29/04
\end{tabular}} & \multicolumn{3}{|c|}{$\begin{array}{c}\text { J01F85 } \\
123 \text { Bldg. (Area 3) } \\
\text { Sample Date 5/5/04 }\end{array}$} \\
\hline & $\mu \mathrm{g} / \mathrm{kg}$ & $Q$ & PQL & $\mu \mathrm{g} / \mathrm{kg}$ & $Q$ & PQL & $\mu \mathrm{g} / \mathrm{kg}$ & $Q$ & PQL & $\mu \mathrm{g} / \mathrm{kg}$ & $Q$ & PQL & $\mu \mathrm{g} / \mathrm{kg}$ & $Q$ & PQL & $\mu \mathrm{g} / \mathrm{kg}$ & $Q$ & PQL & $\mu \mathrm{g} / \mathrm{kg}$ & $Q$ & PQL \\
\hline Aroclor-1016 & 15 & $\mathrm{U}$ & 15 & 14 & $\mathrm{U}$ & 14 & 14 & $\bar{U}$ & 14 & 13 & $\mathrm{U}$ & 13 & 290 & $\mathrm{U}$ & 290 & 970 & $\mathrm{U}$ & 970 & 16 & $\mathrm{U}$ & 16 \\
\hline Aroclor-1221 & 15 & $\mathrm{U}$ & 15 & 14 & $\mathrm{U}$ & 14 & 14 & $\mathrm{U}$ & 14 & 13 & $\mathrm{U}$ & 13 & 290 & $\mathrm{U}$ & 290 & 970 & $\mathrm{U}$ & 970 & 16 & $\mathrm{U}$ & 16 \\
\hline Aroclor-1232 & 15 & $\mathrm{U}$ & 15 & 14 & $\mathrm{U}$ & 14 & 14 & $\mathrm{U}$ & 14 & 13 & $\mathrm{U}$ & 13 & 290 & $\mathrm{U}$ & 290 & 970 & $\mathrm{U}$ & 970 & 16 & $\mathrm{U}$ & 16 \\
\hline Aroclor- 1242 & 15 & $\mathrm{U}$ & 15 & 14 & $\mathrm{U}$ & 14 & 14 & $\mathrm{U}$ & 14 & 13 & $\mathrm{U}$ & 13 & 290 & $\mathrm{U}$ & 290 & 970 & $\mathrm{U}$ & 970 & 16 & $\mathrm{U}$ & 16 \\
\hline Aroclor- 1248 & 15 & $\mathrm{U}$ & 15 & 14 & $\mathrm{U}$ & 14 & 14 & $\mathrm{U}$ & 14 & 13 & $\mathrm{U}$ & 13 & 290 & $\mathrm{U}$ & 290 & 970 & $\mathrm{U}$ & 970 & 16 & $\mathrm{U}$ & 16 \\
\hline Aroclor- 1254 & 15 & $\bar{U}$ & 15 & 14 & $\bar{U}$ & 14 & 14 & $\mathrm{U}$ & 14 & 13 & $U$ & 13 & 290 & $\mathrm{U}$ & 290 & 970 & $\mathrm{U}$ & 970 & 16 & $\mathrm{U}$ & 16 \\
\hline Aroclor- 1260 & 15 & $\mathrm{U}$ & 15 & 14 & $\mathrm{U}$ & 14 & 14 & $\mathrm{U}$ & 14 & 13 & $\mathrm{U}$ & 13 & 1100 & & 290 & 2200 & & 970 & 16 & $\mathrm{U}$ & 16 \\
\hline
\end{tabular}

Table A-6. 600-111 SVOA Data Summary. (3 Pages)

\begin{tabular}{|c|c|c|c|c|c|c|c|c|c|c|c|c|c|c|c|c|c|c|c|c|c|}
\hline \multirow[t]{2}{*}{ Constituent } & \multicolumn{3}{|c|}{$\begin{array}{c}\text { J01F70 } \\
120 \text { Bldg (Area 1) } \\
\text { Sample Date } \\
5 / 5 / 04\end{array}$} & \multicolumn{3}{|c|}{$\begin{array}{c}\text { J01F71 } \\
\text { Crib (Area 2) } \\
\text { Sample Date } \\
5 / 10 / 04 \\
\end{array}$} & \multicolumn{3}{|c|}{$\begin{array}{c}\text { J01F72 } \\
\text { Duplicate (Crib) } \\
\text { Sample Date } \\
5 / 10 / 04\end{array}$} & \multicolumn{3}{|c|}{$\begin{array}{c}\text { J01F82 } \\
\text { Equipment Blank } \\
\text { Sample Date 4/29/04 }\end{array}$} & \multicolumn{3}{|c|}{$\begin{array}{c}\text { J01F83 } \\
\text { Septic Tank (Area 6) } \\
\text { Sample Date } \\
4 / 29 / 04 \\
\end{array}$} & \multicolumn{3}{|c|}{\begin{tabular}{|c|} 
J01F84 \\
Septic Drain Field (Area \\
5) \\
Sample Date $4 / 29 / 04$ \\
\end{tabular}} & \multicolumn{3}{|c|}{$\begin{array}{c}\text { J01F85 } \\
123 \text { Bldg. (Area 3) } \\
\text { Sample Date 5/5/04 }\end{array}$} \\
\hline & $\mu \mathrm{g} / \mathrm{kg}$ & $\mathbf{Q}$ & PQL & $\mu \mathrm{g} / \mathrm{kg}$ & $\mathbf{Q}$ & PQL & $\mu \mathrm{g} / \mathrm{kg}$ & $Q$ & PQL & $\mu \mathrm{g} / \mathrm{kg}$ & Q & PQL & $\mu \mathrm{g} / \mathrm{kg}$ & $\mathbf{Q}$ & $\mathrm{PQL}$ & $\mu \mathrm{g} / \mathrm{kg}$ & $\mathbf{Q}$ & PQL & $\mu \mathrm{g} / \mathrm{kg}$ & $\mathbf{Q}$ & PQL \\
\hline 1,2,4-Trichlorobenzene & 360 & $\mathrm{U}$ & 360 & 350 & $\mathrm{U}$ & 350 & 350 & $\mathrm{U}$ & 350 & 330 & $\mathrm{U}$ & 330 & 720 & $\mathrm{U}$ & 720 & 9700 & $\mathrm{U}$ & 9700 & 400 & $\mathrm{U}$ & 400 \\
\hline 1,2-Dichlorobenzene & 360 & $\mathrm{U}$ & 360 & 350 & $\mathrm{U}$ & 350 & 350 & $\mathrm{U}$ & 350 & 330 & $\mathrm{U}$ & 330 & 720 & $\mathrm{U}$ & 720 & 9700 & $\mathrm{U}$ & 9700 & 400 & $\mathrm{U}$ & 400 \\
\hline 1,3-Dichlorobenzene & 360 & $\mathrm{U}$ & 360 & 350 & $\mathrm{U}$ & 350 & 350 & $\mathrm{U}$ & 350 & 330 & $\mathrm{U}$ & 330 & 720 & $\mathrm{U}$ & 720 & 9700 & $\mathrm{U}$ & 9700 & 400 & $\mathrm{U}$ & 400 \\
\hline 1,4-Dichlorobenzene & 360 & $\mathrm{U}$ & 360 & 350 & $\mathrm{U}$ & 350 & 350 & $\bar{U}$ & 350 & 330 & $\mathrm{U}$ & 330 & 720 & $\mathrm{U}$ & 720 & 9700 & $\mathrm{U}$ & 9700 & 400 & $\mathrm{U}$ & 400 \\
\hline 2,4,5-Trichlorophenol & 910 & $\mathrm{U}$ & 910 & 870 & $U$ & 870 & 870 & $\mathrm{U}$ & 870 & 830 & $\mathrm{U}$ & 830 & 1800 & $\mathrm{U}$ & 1800 & 24000 & $\mathrm{U}$ & 24000 & 1000 & $\mathrm{U}$ & 1000 \\
\hline 2,4,6-Trichlorophenol & 360 & $\mathrm{U}$ & 360 & 350 & $\mathrm{U}$ & 350 & 350 & $\mathrm{U}$ & 350 & 330 & $\mathrm{U}$ & 330 & 720 & $\mathrm{U}$ & 720 & 9700 & $\mathrm{U}$ & 9700 & 400 & $\mathrm{U}$ & 400 \\
\hline 2,4-Dichlorophenol & 360 & $\mathrm{U}$ & 360 & 350 & $\mathrm{U}$ & 350 & 350 & $\mathrm{U}$ & 350 & 330 & $\mathrm{U}$ & 330 & 720 & $\mathrm{U}$ & 720 & 9700 & $\mathrm{U}$ & 9700 & 400 & $\mathrm{U}$ & 400 \\
\hline 2,4-Dimethylphenol & 360 & $\mathrm{U}$ & 360 & 350 & $\mathrm{U}$ & 350 & 350 & $\mathrm{U}$ & 350 & 330 & $\mathrm{U}$ & 330 & 720 & $\mathrm{U}$ & 720 & 9700 & $\mathrm{U}$ & 9700 & 400 & $\mathrm{U}$ & 400 \\
\hline 2,4-Dinitrophenol & 910 & $\mathrm{U}$ & 910 & 870 & $\mathrm{U}$ & 870 & 870 & $\mathrm{U}$ & 870 & 830 & $\mathrm{U}$ & 830 & 1800 & $\mathrm{U}$ & 1800 & 24000 & $\mathrm{U}$ & 24000 & 1000 & $\mathrm{U}$ & 1000 \\
\hline 2,4-Dinitrotoluene & 360 & $\mathrm{U}$ & 360 & 350 & $\mathrm{U}$ & 350 & 350 & $\mathrm{U}$ & 350 & 330 & $\mathrm{U}$ & 330 & 720 & $\mathrm{U}$ & 720 & 9700 & $\mathrm{U}$ & 9700 & 400 & $\mathrm{U}$ & 400 \\
\hline 2,6-Dinitrotoluene & 360 & $\mathrm{U}$ & 360 & 350 & $\mathrm{U}$ & 350 & 350 & $\mathrm{U}$ & 350 & 330 & $\mathrm{U}$ & 330 & 720 & $\mathrm{U}$ & 720 & 9700 & $\mathrm{U}$ & 9700 & 400 & $\mathrm{U}$ & 400 \\
\hline 2-Chloronaphthalene & 360 & $\mathrm{U}$ & 360 & 350 & $\mathrm{U}$ & 350 & 350 & $\mathrm{U}$ & 350 & 330 & $\mathrm{U}$ & 330 & 720 & $\mathrm{U}$ & 720 & 9700 & $\mathrm{U}$ & 9700 & 400 & $\mathrm{U}$ & 400 \\
\hline 2-Chlorophenol & 360 & $\mathrm{U}$ & 360 & 350 & $\mathrm{U}$ & 350 & 350 & $\mathrm{U}$ & 350 & 330 & $\mathrm{U}$ & 330 & 720 & $\mathrm{U}$ & 720 & 9700 & $\mathrm{U}$ & 9700 & 400 & $\mathrm{U}$ & 400 \\
\hline 2-Methylnaphthalene & 360 & $\mathrm{U}$ & 360 & 350 & $\mathrm{U}$ & 350 & 350 & $\mathrm{U}$ & 350 & 330 & $\mathrm{U}$ & 330 & 720 & $\mathrm{U}$ & 720 & 9700 & $\mathrm{U}$ & 9700 & 400 & $\mathrm{U}$ & 400 \\
\hline 2-Methylphenol (cresol, o-) & 360 & $\mathrm{U}$ & 360 & 350 & $\mathrm{U}$ & 350 & 350 & $\mathrm{U}$ & 350 & 330 & $\mathrm{U}$ & 330 & 720 & $\mathrm{U}$ & 720 & 9700 & $\mathrm{U}$ & 9700 & 400 & $\mathrm{U}$ & 400 \\
\hline 2-Nitroaniline & 910 & $\mathrm{U}$ & 910 & 870 & $\mathrm{U}$ & 870 & 870 & $\mathrm{U}$ & 870 & 830 & $\mathrm{U}$ & 830 & 1800 & $\mathrm{U}$ & 1800 & 24000 & $\mathrm{U}$ & 24000 & 1000 & $\mathrm{U}$ & 1000 \\
\hline 2-Nitrophenol & 360 & $\mathrm{U}$ & 360 & 350 & $\mathrm{U}$ & 350 & 350 & $\bar{U}$ & 350 & 330 & $\bar{U}$ & 330 & 720 & $\mathrm{U}$ & 720 & 9700 & $\mathrm{U}$ & 9700 & 400 & $\mathrm{U}$ & 400 \\
\hline
\end{tabular}


Table A-6. 600-111 SVOA Data Summary. (3 Pages)

\begin{tabular}{|c|c|c|c|c|c|c|c|c|c|c|c|c|c|c|c|c|c|c|c|c|c|}
\hline \multirow[t]{2}{*}{ Constituent } & \multicolumn{3}{|c|}{$\begin{array}{c}\text { J01F70 } \\
120 \text { Bldg (Area 1) } \\
\text { Sample Date } \\
5 / 5 / 04\end{array}$} & \multicolumn{3}{|c|}{$\begin{array}{c}\text { J01F71 } \\
\text { Crib (Area 2) } \\
\text { Sample Date } \\
5 / 10 / 04\end{array}$} & \multicolumn{3}{|c|}{$\begin{array}{c}\text { J01F72 } \\
\text { Duplicate (Crib) } \\
\text { Sample Date } \\
5 / 10 / 04\end{array}$} & \multicolumn{3}{|c|}{$\begin{array}{c}\text { J01F82 } \\
\text { Equipment Blank } \\
\text { Sample Date 4/29/04 }\end{array}$} & \multicolumn{3}{|c|}{\begin{tabular}{c|}
$J 01 F 83$ \\
Septic Tank (Area 6) \\
Sample Date \\
4/29/04
\end{tabular}} & \multicolumn{3}{|c|}{\begin{tabular}{|c|} 
J01F84 \\
Septic Drain Field (Area \\
5 ) \\
Sample Date $4 / 29 / 04$
\end{tabular}} & \multicolumn{3}{|c|}{$\begin{array}{c}\text { J01F85 } \\
\text { 123 Bldg. (Area 3) } \\
\text { Sample Date 5/5/04 }\end{array}$} \\
\hline & $\mu \mathrm{g} / \mathrm{kg}$ & Q & PQL & $\mu \mathrm{g} / \mathrm{kg}$ & $Q$ & $\mathbf{P Q L}$ & $\mu \mathrm{g} / \mathrm{kg}$ & $\mathrm{Q}$ & $\mathrm{PQL}$ & $\mu \mathrm{g} / \mathrm{kg}$ & $\mathrm{Q}$ & PQL & $\mu \mathrm{g} / \mathrm{kg}$ & Q & PQL & $\mu \mathrm{g} / \mathrm{kg}$ & $Q$ & $\mathrm{PQL}$ & $\mu \mathrm{g} / \mathrm{kg}$ & $\mathbf{Q}$ & PQL \\
\hline 3,3'-Dichlorobenzidine & 360 & $\mathrm{U}$ & 360 & 350 & $\mathrm{U}$ & 350 & 350 & $\mathrm{U}$ & 350 & 330 & $\mathrm{U}$ & 330 & 720 & $\mathrm{U}$ & 720 & 9700 & $\mathrm{U}$ & 9700 & 400 & $\mathrm{U}$ & 400 \\
\hline 3-Nitroaniline & 910 & $\mathrm{U}$ & 910 & 870 & $\mathrm{U}$ & 870 & 870 & $\mathrm{U}$ & 870 & 830 & $\mathrm{U}$ & 830 & 1800 & $\bar{U}$ & 1800 & 24000 & $\mathrm{U}$ & 24000 & 1000 & $\mathrm{U}$ & 1000 \\
\hline 4,6-Dinitro-2-methylphenol & 910 & $\mathrm{U}$ & 910 & 870 & $\mathrm{U}$ & 870 & 870 & $\mathrm{U}$ & 870 & 830 & $\mathrm{U}$ & 830 & 1800 & $\mathrm{U}$ & 1800 & 24000 & $\mathrm{U}$ & 24000 & 1000 & $\mathrm{U}$ & 1000 \\
\hline 4-Bromophenylphenyl ether & 360 & $\mathrm{U}$ & 360 & 350 & $\mathrm{U}$ & 350 & 350 & $\mathrm{U}$ & 350 & 330 & $\mathrm{U}$ & 330 & 720 & $\mathrm{U}$ & 720 & 9700 & $\mathrm{U}$ & 9700 & 400 & $\mathrm{U}$ & 400 \\
\hline 4-Chloro-3-methylphenol & 360 & $\mathrm{U}$ & 360 & 350 & $\mathrm{U}$ & 350 & 350 & $\mathrm{U}$ & 350 & 330 & $\mathrm{U}$ & 330 & 720 & $\mathrm{U}$ & 720 & 9700 & $\mathrm{U}$ & 9700 & 400 & $\mathrm{U}$ & 400 \\
\hline 4-Chloroaniline & 360 & $\mathrm{U}$ & 360 & 350 & $\mathrm{U}$ & 350 & 350 & $\mathrm{U}$ & 350 & 330 & $\mathrm{U}$ & 330 & 720 & $\mathrm{U}$ & 720 & 9700 & $\mathrm{U}$ & 9700 & 400 & $\mathrm{U}$ & 400 \\
\hline 4-Chlorophenylphenyl ether & 360 & $\mathrm{U}$ & 360 & 350 & $\mathrm{U}$ & 350 & 350 & $\mathrm{U}$ & 350 & 330 & $\mathrm{U}$ & 330 & 720 & $\mathrm{U}$ & 720 & 9700 & $\mathrm{U}$ & 9700 & 400 & $\mathrm{U}$ & 400 \\
\hline 4-Methylphenol (cresol, p-) & 360 & $\mathrm{U}$ & 360 & 350 & $\mathrm{U}$ & 350 & 350 & $\mathrm{U}$ & 350 & 330 & $\mathrm{U}$ & 330 & 720 & $\mathrm{U}$ & 720 & 9700 & $\mathrm{U}$ & 9700 & 400 & $\mathrm{U}$ & 400 \\
\hline 4-Nitroaniline & 910 & $\mathrm{U}$ & 910 & 870 & $\mathrm{U}$ & 870 & 870 & $\mathrm{U}$ & 870 & 830 & $\mathrm{U}$ & 830 & 1800 & $\mathrm{U}$ & 1800 & 24000 & $\mathrm{U}$ & 24000 & 1000 & $\mathrm{U}$ & 1000 \\
\hline 4-Nitrophenol & 910 & $\mathrm{U}$ & 910 & 870 & $\mathrm{U}$ & 870 & 870 & $\mathrm{U}$ & 870 & 830 & $\mathrm{U}$ & 830 & 1800 & $\mathrm{U}$ & 1800 & 24000 & $\mathrm{U}$ & 24000 & 1000 & $\mathrm{U}$ & 1000 \\
\hline Acenaphthene & 360 & $\mathrm{U}$ & 360 & 350 & $\mathrm{U}$ & 350 & 350 & $\mathrm{U}$ & 350 & 330 & $\mathrm{U}$ & 330 & 720 & $\mathrm{U}$ & 720 & 9700 & $\mathrm{U}$ & 9700 & 400 & $\mathrm{U}$ & 400 \\
\hline Acenaphthylene & 360 & $\mathrm{U}$ & 360 & 350 & $\mathrm{U}$ & 350 & 350 & $\mathrm{U}$ & 350 & 330 & $\mathrm{U}$ & 330 & 720 & $\mathrm{U}$ & 720 & 9700 & $\mathrm{U}$ & 9700 & 400 & $\mathrm{U}$ & 400 \\
\hline Anthracene & 360 & $\mathrm{U}$ & 360 & 350 & $\mathrm{U}$ & 350 & 350 & $\mathrm{U}$ & 350 & 330 & $\mathrm{U}$ & 330 & 720 & $\mathrm{U}$ & 720 & 9700 & $\mathrm{U}$ & 9700 & 400 & $\mathrm{U}$ & 400 \\
\hline Benzo(a)anthracene & 360 & $\mathrm{U}$ & 360 & 350 & $\mathrm{U}$ & 350 & 350 & $\mathrm{U}$ & 350 & 330 & $\mathrm{U}$ & 330 & 55 & $\mathrm{~J}$ & 720 & 9700 & $\mathrm{U}$ & 9700 & 400 & $\mathrm{U}$ & 400 \\
\hline Benzo(a)pyrene & 360 & $\mathrm{U}$ & 360 & 350 & $\mathrm{U}$ & 350 & 350 & $\mathrm{U}$ & 350 & 330 & $\mathrm{U}$ & 330 & 720 & $\mathrm{U}$ & 720 & 9700 & $\mathrm{U}$ & 9700 & 400 & $\mathrm{U}$ & 400 \\
\hline Benzo(b)fluoranthene & 360 & $\mathrm{U}$ & 360 & 350 & $\mathrm{U}$ & 350 & 350 & $\mathrm{U}$ & 350 & 330 & $\mathrm{U}$ & 330 & 720 & $\mathrm{U}$ & 720 & 9700 & $\mathrm{U}$ & 9700 & 400 & $\mathrm{U}$ & 400 \\
\hline Benzo(ghi)perylene & 360 & $\mathrm{U}$ & 360 & 350 & $\mathrm{U}$ & 350 & 350 & $\mathrm{U}$ & 350 & 330 & $\mathrm{U}$ & 330 & 720 & $\mathrm{U}$ & 720 & 9700 & $\mathrm{U}$ & 9700 & 400 & $\mathrm{U}$ & 400 \\
\hline Benzo(k)fluoranthene & 360 & $\mathrm{U}$ & 360 & 350 & $\mathrm{U}$ & 350 & 350 & $\mathrm{U}$ & 350 & & $\mathrm{U}$ & & 720 & $\mathrm{U}$ & 720 & 9700 & $\mathrm{U}$ & 9700 & 400 & $\mathrm{U}$ & 400 \\
\hline $\begin{array}{l}\text { Bis(2-chloro-1- } \\
\text { methylethyl)ether }\end{array}$ & 360 & $\mathrm{U}$ & 360 & 350 & $\mathrm{U}$ & 350 & 350 & $\mathrm{U}$ & 350 & 330 & $\mathrm{U}$ & 330 & 720 & $\mathrm{U}$ & 720 & 9700 & $\mathrm{U}$ & 9700 & 400 & $\mathrm{U}$ & 400 \\
\hline Bis(2-Chloroethoxy)methane & 360 & $\mathrm{U}$ & 360 & 350 & $\mathrm{U}$ & 350 & 350 & $\mathrm{U}$ & 350 & 330 & $\mathrm{U}$ & 330 & 720 & $\mathrm{U}$ & 720 & 9700 & $\mathrm{U}$ & 9700 & 400 & $\mathrm{U}$ & 400 \\
\hline Bis(2-chloroethyl) ether & 360 & $\mathrm{U}$ & 360 & 350 & $\mathrm{U}$ & 350 & 350 & $\mathrm{U}$ & 350 & 330 & $\mathrm{U}$ & 330 & 720 & $\mathrm{U}$ & 720 & 9700 & $\mathrm{U}$ & 9700 & 400 & $\mathrm{U}$ & 400 \\
\hline Bis(2-ethylhexyl) phthalate & 360 & $\mathrm{U}$ & 360 & 350 & $\mathrm{U}$ & 350 & 350 & $\mathrm{U}$ & 350 & 330 & $\mathrm{U}$ & 330 & 100 & $\mathrm{~J}$ & 720 & 9700 & $\mathrm{U}$ & 9700 & 400 & $\mathrm{U}$ & 400 \\
\hline Butylbenzylphthalate & 360 & $\mathrm{U}$ & 360 & 350 & $\mathrm{U}$ & 350 & 350 & $\mathrm{U}$ & 350 & 330 & $\mathrm{U}$ & 330 & 720 & $\mathrm{U}$ & 720 & 9700 & $\mathrm{U}$ & 9700 & 400 & $\mathrm{U}$ & 400 \\
\hline Carbazole & 360 & $\mathrm{U}$ & 360 & 350 & $\mathrm{U}$ & 350 & 350 & $\mathrm{U}$ & 350 & 330 & $\mathrm{U}$ & 330 & 720 & $\mathrm{U}$ & 720 & 9700 & $\mathrm{U}$ & 9700 & 400 & $\mathrm{U}$ & 400 \\
\hline Chrysene & 360 & $\mathrm{U}$ & 360 & 350 & $\mathrm{U}$ & 350 & 350 & $\mathrm{U}$ & 350 & 330 & $\mathrm{U}$ & 330 & 73 & $\mathrm{~J}$ & 720 & 9700 & $\mathrm{U}$ & 9700 & 400 & $\mathrm{U}$ & 400 \\
\hline Dibenz[a,h]anthracene & 360 & $\mathrm{U}$ & 360 & 350 & $\mathrm{U}$ & 350 & 350 & $\mathrm{U}$ & 350 & 330 & $\mathrm{U}$ & 330 & 720 & $\mathrm{U}$ & 720 & 9700 & $\mathrm{U}$ & 9700 & 400 & $\mathrm{U}$ & 400 \\
\hline Dibenzofuran & 360 & $\mathrm{U}$ & 360 & 350 & $\mathrm{U}$ & 350 & 350 & $\mathrm{U}$ & 350 & 330 & $\mathrm{U}$ & 330 & 720 & $\mathrm{U}$ & 720 & 9700 & $\mathrm{U}$ & 9700 & 400 & $\mathrm{U}$ & 400 \\
\hline Diethylphthalate & 360 & $\mathrm{U}$ & 360 & 350 & $\mathrm{U}$ & 350 & 350 & $\mathrm{U}$ & 350 & 330 & $\mathrm{U}$ & 330 & 720 & $\mathrm{U}$ & 720 & 9700 & $\mathrm{U}$ & 9700 & 400 & $\mathrm{U}$ & 400 \\
\hline Dimethyl phthalate & 360 & $\mathrm{U}$ & 360 & 350 & $\mathrm{U}$ & 350 & 350 & $\mathrm{U}$ & 350 & 330 & $\mathrm{U}$ & 330 & 720 & $\mathrm{U}$ & 720 & 9700 & $\mathrm{U}$ & 9700 & 400 & $\mathrm{U}$ & 400 \\
\hline Di-n-butylphthalate & 360 & $\mathrm{U}$ & 360 & 350 & $\mathrm{U}$ & 350 & 350 & $\mathrm{U}$ & 350 & 330 & $\mathrm{U}$ & 330 & 720 & $\mathrm{U}$ & 720 & 9700 & $\mathrm{U}$ & 9700 & 400 & $\mathrm{U}$ & 400 \\
\hline
\end{tabular}


Table A-6. 600-111 SVOA Data Summary. (3 Pages)

\begin{tabular}{|c|c|c|c|c|c|c|c|c|c|c|c|c|c|c|c|c|c|c|c|c|c|}
\hline \multirow[t]{2}{*}{ Constituent } & \multicolumn{3}{|c|}{$\begin{array}{c}\text { J01F70 } \\
\text { 120 Bldg (Area 1) } \\
\text { Sample Date } \\
5 / 5 / 04 \\
\end{array}$} & \multicolumn{3}{|c|}{$\begin{array}{c}\text { J01F71 } \\
\text { Crib (Area 2) } \\
\text { Sample Date } \\
5 / 10 / 04 \\
\end{array}$} & \multicolumn{3}{|c|}{$\begin{array}{c}\text { J01F72 } \\
\text { Duplicate (Crib) } \\
\text { Sample Date } \\
\text { 5/10/04 }\end{array}$} & \multicolumn{3}{|c|}{$\begin{array}{c}\text { J01F82 } \\
\text { Equipment Blank } \\
\text { Sample Date 4/29/04 }\end{array}$} & \multicolumn{3}{|c|}{$\begin{array}{c}\text { J01F83 } \\
\text { Septic Tank (Area 6) } \\
\text { Sample Date } \\
4 / 29 / 04 \\
\end{array}$} & \multicolumn{3}{|c|}{\begin{tabular}{|c|} 
J01F84 \\
Septic Drain Field (Area \\
5) \\
Sample Date $4 / 29 / 04$ \\
\end{tabular}} & \multicolumn{3}{|c|}{$\begin{array}{c}\text { J01F85 } \\
123 \text { Bldg. (Area 3) } \\
\text { Sample Date 5/5/04 }\end{array}$} \\
\hline & $\mu \mathrm{g} / \mathrm{kg}$ & $Q$ & PQL & $\mu \mathrm{g} / \mathrm{kg}$ & $Q$ & PQL & $\mu \mathrm{g} / \mathrm{kg}$ & $\mathbf{Q}$ & PQL & $\mu \mathrm{g} / \mathrm{kg}$ & $\mathbf{Q}$ & $\mathrm{PQL}$ & $\mu \mathrm{g} / \mathrm{kg}$ & $\mathbf{Q}$ & PQL & $\mu \mathrm{g} / \mathrm{kg}$ & $Q$ & PQL & $\mu \mathrm{g} / \mathrm{kg}$ & Q & PQL \\
\hline Di-n-octylphthalate & 360 & $\mathrm{U}$ & 360 & 350 & $\mathrm{U}$ & 350 & 350 & $\mathrm{U}$ & 350 & 330 & $\mathrm{U}$ & 330 & 720 & $\mathrm{U}$ & 720 & 9700 & $\mathrm{U}$ & 9700 & 400 & $\mathrm{U}$ & 400 \\
\hline Fluoranthene & 360 & $\mathrm{U}$ & 360 & 350 & $\mathrm{U}$ & 350 & 350 & $\mathrm{U}$ & 350 & 330 & $\mathrm{U}$ & 330 & 170 & $\mathrm{~J}$ & 720 & 9700 & $\mathrm{U}$ & 9700 & 400 & $\mathrm{U}$ & 400 \\
\hline Fluorene & 360 & U & 360 & 350 & $\mathrm{U}$ & 350 & 350 & $\mathrm{U}$ & 350 & 330 & $\mathrm{U}$ & 330 & 720 & $\mathrm{U}$ & 720 & 9700 & $\mathrm{U}$ & 9700 & 400 & $\mathrm{U}$ & 400 \\
\hline Hexachlorobenzene & 360 & $\mathrm{U}$ & 360 & 350 & $\mathrm{U}$ & 350 & 350 & $\mathrm{U}$ & 350 & 330 & $\mathrm{U}$ & 330 & 720 & $\mathrm{U}$ & 720 & 9700 & $\mathrm{U}$ & 9700 & 400 & $\mathrm{U}$ & 400 \\
\hline Hexachlorobutadiene & 360 & $\mathrm{U}$ & 360 & 350 & $\mathrm{U}$ & 350 & 350 & $\mathrm{U}$ & 350 & 330 & $\mathrm{U}$ & 330 & 720 & $\mathrm{U}$ & 720 & 9700 & $\mathrm{U}$ & 9700 & 400 & $\mathrm{U}$ & 400 \\
\hline Hexachlorocyclopentadiene & 360 & $U$ & 360 & 350 & $\mathrm{U}$ & 350 & 350 & $\mathrm{U}$ & 350 & 330 & $\mathrm{U}$ & 330 & 720 & $\mathrm{U}$ & 720 & 9700 & $\mathrm{U}$ & 9700 & 400 & $\mathrm{U}$ & 400 \\
\hline Hexachloroethane & 360 & $\mathrm{U}$ & 360 & 350 & $\mathrm{U}$ & 350 & 350 & $\mathrm{U}$ & 350 & 330 & $\mathrm{U}$ & 330 & 720 & $\mathrm{U}$ & 720 & 9700 & $\mathrm{U}$ & 9700 & 400 & $\mathrm{U}$ & 400 \\
\hline Indeno(1,2,3-cd)pyrene & 360 & $\mathrm{U}$ & 360 & 350 & $\mathrm{U}$ & 350 & 350 & $\mathrm{U}$ & 350 & 330 & $\mathrm{U}$ & 330 & 720 & $\mathrm{U}$ & 720 & 9700 & $\mathrm{U}$ & 9700 & 400 & $\mathrm{U}$ & 400 \\
\hline Isophorone & 360 & $\mathrm{U}$ & 360 & 350 & $\mathrm{U}$ & 350 & 350 & $\mathrm{U}$ & 350 & 330 & $U$ & 330 & 720 & $\mathrm{U}$ & 720 & 9700 & $\mathrm{U}$ & 9700 & 400 & $\mathrm{U}$ & 400 \\
\hline Naphthalene & 360 & $\mathrm{U}$ & 360 & 350 & $\mathrm{U}$ & 350 & 350 & $\mathrm{U}$ & 350 & 330 & $\mathrm{U}$ & 330 & 720 & $\mathrm{U}$ & 720 & 9700 & $\mathrm{U}$ & 9700 & 400 & $\mathrm{U}$ & 400 \\
\hline Nitrobenzene & 360 & $\mathrm{U}$ & 360 & 350 & $\mathrm{U}$ & 350 & 350 & $\mathrm{U}$ & 350 & 330 & $\mathrm{U}$ & 330 & 720 & $\mathrm{U}$ & 720 & 9700 & $\mathrm{U}$ & 9700 & 400 & $\mathrm{U}$ & 400 \\
\hline N-Nitroso-di-n-dipropylamine & 360 & $\mathrm{U}$ & 360 & 350 & $\mathrm{U}$ & 350 & 350 & $\mathrm{U}$ & 350 & 330 & $\mathrm{U}$ & 330 & 720 & $\mathrm{U}$ & 720 & 9700 & $\mathrm{U}$ & 9700 & 400 & $\mathrm{U}$ & 400 \\
\hline \begin{tabular}{|l|}
$\mathrm{N}$-Nitrosodiphenylamine \\
\end{tabular} & 360 & $\mathrm{U}$ & 360 & 350 & $\mathrm{U}$ & 350 & 350 & $\mathrm{U}$ & 350 & 330 & $\mathrm{U}$ & 330 & 720 & $\mathrm{U}$ & 720 & 9700 & $\mathrm{U}$ & 9700 & 400 & $\mathrm{U}$ & 400 \\
\hline Pentachlorophenol & 910 & $\mathrm{U}$ & 910 & 870 & $\mathrm{U}$ & 870 & 870 & $\mathrm{U}$ & 870 & 830 & $\mathrm{U}$ & 830 & 1800 & $\mathrm{U}$ & 1800 & 24000 & $\mathrm{U}$ & 24000 & 1000 & $\mathrm{U}$ & 1000 \\
\hline \begin{tabular}{|l|} 
Phenanthrene \\
\end{tabular} & 360 & $\mathrm{U}$ & 360 & 350 & $\mathrm{U}$ & 350 & 350 & $\mathrm{U}$ & 350 & 330 & $\mathrm{U}$ & 330 & 720 & $\mathrm{U}$ & 720 & 9700 & $\mathrm{U}$ & 9700 & 400 & $\mathrm{U}$ & 400 \\
\hline \begin{tabular}{|l|} 
Phenol \\
\end{tabular} & 360 & $\mathrm{U}$ & 360 & 350 & $\mathrm{U}$ & 350 & 350 & $\mathrm{U}$ & 350 & 330 & $\mathrm{U}$ & 330 & 720 & $\mathrm{U}$ & 720 & 9700 & $\mathrm{U}$ & 9700 & 400 & $\mathrm{U}$ & 400 \\
\hline Pyrene & 360 & $\mathrm{U}$ & 360 & 350 & $\mathrm{U}$ & 350 & 350 & $\mathrm{U}$ & 350 & 330 & $\mathrm{U}$ & 330 & 720 & $\mathrm{U}$ & 720 & 9700 & $\mathrm{U}$ & 9700 & 25.085 & $\mathrm{~J}$ & 400 \\
\hline
\end{tabular}

Table A-7. TCLP Semi-volatile Data Summary.

\begin{tabular}{|l|c|c|c|}
\hline \multirow{2}{*}{ Constituent } & \multicolumn{3}{c|}{$\begin{array}{c}\text { J0185 } \\
\text { Septic Drain Field } \\
\text { Sample Date 5/5/04 }\end{array}$} \\
\cline { 2 - 4 } & $\boldsymbol{\mu g} / \mathbf{m L}$ & $\mathbf{Q}$ & $\mathbf{P Q L}$ \\
\hline Pyridine & 0.05 & $\mathrm{U}$ & 0.5 \\
\hline 1,4-Dichlorobenzene & 0.05 & $\mathrm{U}$ & 0.05 \\
\hline 2-Methyphenol & 0.05 & $\mathrm{U}$ & 0.05 \\
\hline 3- and/or 4- Methylphenol & 0.05 & $\mathrm{U}$ & 0.05 \\
\hline Hexachloroethane & 0.05 & $\mathrm{U}$ & 0.05 \\
\hline Hexachlorobutadiene & 0.05 & $\mathrm{U}$ & 0.05 \\
\hline
\end{tabular}

\begin{tabular}{|l|c|c|c|}
\hline \multirow{2}{*}{ Constituent } & \multicolumn{3}{c|}{$\begin{array}{c}\text { J0185 } \\
\text { Septic Drain Field } \\
\text { Sample Date 5/5/04 }\end{array}$} \\
\cline { 2 - 4 } & $\boldsymbol{\mu g} / \mathbf{m L}$ & $\mathbf{Q}$ & $\mathrm{PQL}$ \\
\hline $2,4,6$-Trichlorophenol & 0.05 & $\mathrm{U}$ & 0.05 \\
\hline $2,4,5$ - Trichlorophenol & 0.12 & $\mathrm{U}$ & 0.12 \\
\hline 2,4-Dinitrotoluene & 0.05 & $\mathrm{U}$ & 0.05 \\
\hline Hexachlorobenzene & 0.05 & $\mathrm{U}$ & 0.05 \\
\hline Pentachlorophenol & 0.12 & $\mathrm{U}$ & 0.12 \\
\hline Nitrobenzene & 0.05 & $\mathrm{U}$ & 0.05 \\
\hline
\end{tabular}

$\mathrm{J} \quad=$ estimated $\quad \mathrm{PQL} \quad=$ practical quantitation limit

$\mathrm{PCB} \quad=$ polychlorinated biphenyl $\mathrm{Q}=$ qualifier
SVOA = semi-volatile organic analysis

TCLP $=$ toxicity characteristic leaching procedure
$\mathrm{U}=$ undetected 


\section{APPENDIX B}

\section{DATA QUALITY ASSESSMENT}




\section{CONFIRMATORY SAMPLING}

A data quality assessment (DQA) was performed to compare the confirmatory sampling approach and resulting analytical data with the sampling and data requirements specified in the site-specific sample design (BHI 2004b). This DQA was performed in accordance with site specific data quality objectives found in the 100 Area Remedial Action Sampling and Analysis Plan (SAP) (DOE-RL 2005a).

This DQA was performed in accordance with BHI-EE-01, Environmental Investigations Procedures. Specific data quality objectives (DQOs) for confirmatory sampling for this site are found in the Sampling and Analysis Plan for the 100 Area Remaining Sites (DOE-RL 2000) for confirmatory sampling and in the 100 Area Remedial Action Sampling and Analysis Plan (DOE-RL 2004a) for the verification sampling. To ensure data quality requirements, the validation procedures for chemical analysis (BHI 2000a) and radiochemical analysis (BHI 2000b) are followed where appropriate.

The DQA for the confirmatory sampling determined that the data are of the right type, quality, and quantity to support site decisions within specified error tolerances. All analytical data were found to be acceptable for decision-making purposes. The evaluation verified that the focused sampling design and resulting confirmatory sampling data are sufficient for the purpose of determining portions of the site that meet the cleanup criteria and portions that require remedial action. The confirmatory sampling data are stored in the Hanford Environmental Information System (HEIS) and are summarized in Appendix A.

The review of the data validation package (BHI 2004a) and the data that were not validated showed no major deficiencies that affect use of the data. Minor deficiencies included the following:

- Matrix spike (MS) recoveries for antimony that were outside of quality control (QC) limits were qualified as estimates.

- Relative percent differences (RPDs) for some semivolatile organic compounds (SVOCs) were outside control limits and qualified as estimates.

- The RPD for copper and cadmium in a single sample were outside the control limits.

- The detection limit for some SVOC results exceeded the contract required quantitation limit due to sample dilutions related to matrix interference.

- Surrogate recoveries were unattainable for two samples due to matrix interference and high concentrations of target analytes in the samples.

- The laboratory control sample (LCS) for mercury for one sample was outside the control limit; however, there is no bias evident because the sample result was nondetect.

The number and types of minor deficiencies are well within the expectations for the matrix types and analyses performed, and therefore the DQA review for the 600-111 site concludes that the data are of the right type, quality, and quantity to support the intended use. Detection limits, precision, accuracy, and sampling group data completeness were assessed to determine if any analytical results should be rejected as a result of quality assurance and quality control deficiencies. The DQA review found the results to be 
accurate within the standard errors associated with the methods, including sampling and sample handling.

Uranium was not identified as a contaminant of concern (COC) or contaminant of potential concern (COPC) for the 600-111 site. Gamma energy analysis (GEA) was specified to assess levels of contamination of other gamma-emitting COPCs. Results for uranium-235 and uranium-238 were routinely reported as part of the standard reporting suite for GEA. A standard reporting suite is used to minimize confusion or misreporting issues inherent if multiple custom reporting suites are requested from a laboratory to the same primary client. All uranium results were nondetect; however, minimum detectable activities were above Hanford Site background levels. These nondetect results provide no information on potential activities present below the minimum detectable activities. The reported results for radium-226 indicate that uranium is present at approximately Hanford Site background levels. There are no indications of any potential for non-natural uranium contamination at these sites.

\section{Confirmatory Data Quality Assessment Summary}

Limited, random, or sample matrix-specific influenced batch QC issues such as those discussed above are a potential for any analysis. The number and types seen in these data sets are within expectations for the matrix types and analyses performed. The DQA review of the 600-111 confirmatory sampling data found that the analytical results are accurate within the standard errors associated with the analytical methods, sampling, and sample handling. The DQA review for the 600-111 waste site concludes that the reviewed data are of the right type, quality, and quantity to support the intended use. Detection limits, precision, accuracy, and sampling data group completeness were assessed to determine if any analytical results should be qualified as a result of quality assurance (QA) and QC deficiencies. The analytical data were found acceptable for decision-making purposes. The confirmatory sample analytical data are stored in the Environmental Restoration (ENRE) project-specific database prior to being submitted for inclusion in the Hanford Environmental Information System (HEIS) database. The confirmatory sample analytical data are also summarized in Appendix A.

\section{VERIFICATION SAMPLING}

A DQA was performed to compare the verification sampling approach and resulting analytical data with the sampling and data requirements specified in the site-specific sample design (WHC 2008c). This DQA was performed in accordance with site specific data quality objectives found in the SAP (DOE-RL 2005a).

A review of the sample design (WCH 2008c), the field logbook (WCH 2008a), and applicable analytical data package has been performed as part of this DQA. All samples were collected per the sample design. To ensure quality data, the SAP data assurance requirements and the data validation procedures for chemical analysis (BHI 2000a) are used as appropriate. This review involves evaluation of the data to determine if they are of the right type, quality, and quantity to support the intended use (i.e., closeout decisions). The DQA completes the data life cycle (i.e., planning, implementation, and assessment) that was initiated by the data quality objectives process (EPA 2000).

Verification sample data collected at the 600-111 waste site were provided by the laboratories in one sample delivery group (SDG) K1207. SDG K1207 was submitted for third-party validation 
(WCH 2008b). No major deficiencies were identified in the data set. Minor deficiencies are discussed below.

\section{SDG K1207}

This SDG comprises 11 verification samples (J16MM8-J16MM9 and J16MN0-J16MN8) collected from the base of the 600-111 excavation. A field duplicate pair (J16MN5/J16MN6) is included in this SDG. These samples were analyzed for inductively coupled plasma (ICP) metals, mercury, semivolatile organic compounds (SVOCs), and polychlorinated biphenyls (PCBs). In addition, one equipment blank (J16MM7) was collected and analyzed for ICP metals and mercury. SDG K1207 was submitted for formal third-party validation. No major deficiencies were found in SDG K1207. Minor deficiencies are as follows:

In the SVOC analysis, the MS recoveries are below the acceptance criteria for bis(2-chloroethyl)ether and hexachloroethane, at $49 \%$ and $48 \%$, respectively. The matrix spike duplicate (MSD) recoveries are below the acceptance criteria for 2,2'-oxybis(1-chloropropane) and 2,4-dinitrophenol, at 49\% and 12\%, respectively. The LCS recovery was outside QC limits for 2,4-dinitrophenol (5\%), 4,6-dinitro-2methylphenol (16\%), and pentachlorophenol (42\%). All results for analytes with low MS, MSD, or LCS recoveries were qualified as estimates and flagged "J" by third-party validation. Estimated data are useable for decision-making purposes.

In the SVOC analysis, surrogate recoveries are outside the acceptance criteria for four samples. Due to surrogate recoveries outside QC limits, all 2,4-dinitrophenol, 2,4,6-trichlorophenol, 2,4,5trichlorophenol, pentachlorophenol, bis(2-chloroethyl)ether, bis(2-chloroethoxy)methane, and 4-chlorophenyl phenyl ether results in samples J16MM9, J16MN3, J16MN7, and J16MN8 were qualified as estimates and flagged "J" by third-party validation. All 2-ntirophenol, 2,4-diitrophenol, nitrobenzene, n-nitroso-di-n-propylamine, 4-chloroaniline, 2-nitroaniline, 3-nitroaniline, 4-nitroaniline, 2,6-dinitrotoluene, n-nitrosodiphenylamine, phenol, 2-methylphenol, 3/4-methylphenol, 2,4dimethylphenol, 2-nitrophenol, 2,4-dinitrophenol, dimethyl phthalate, diethyl phthalate, di-n-butyl phthalate, butylbenzylphthalate, bis(2-ethylhexyl) phthalate, and di-n-octylphthalate results in sample J16MN1 were qualified as estimates and flagged "J" by third-party validation due to surrogate recoveries outside QC limits. Estimated data are useable for decision-making purposes.

In the SVOC analysis, the laboratory duplicate relative percent differences (RPDs) for 2,4-dinitrophenol (107\%) and 4-nitrophenol (55\%) are greater than 30\%. The results for these analytes in SDG K1207 samples were qualified as estimates and flagged "J" by third party validation. Estimated data are useable for decision making purposes.

In the PCB analysis, the MSD analysis was not performed. As a result, all PCB results for SDG K1207 were qualified by third-party validation as estimated with "J" flags. Estimated, or "J"-flagged, data are acceptable for decision-making purposes.

In the ICP metals analysis, the calcium and sodium results for sample J16MM7 (the equipment blank) are of similar magnitude as the method blank results. These results are qualified by third-party validation as estimates with "J" flags. The sodium results for samples J16MN2 and J16MN3 are less than five times the method blank results. Due to method blank contamination, these results are qualified by third-party validation as undetected estimates with "UJ" flags. The data are useable for decisionmaking purposes. 
Also in the ICP metals analysis, the MS recoveries for five ICP metals (aluminum, iron, manganese, antimony, and silicon) are out of acceptance criteria. For most of these analytes, the spiking concentration is insignificant compared to the native concentration in the sample from which the MS was prepared. Therefore, the deficiency in the MS result is a reflection of the analytical variability of the native concentration rather than a measure of the recovery from the sample. To confirm quantitation, post-digestion spikes and serial dilutions were prepared for all five analytes with acceptable results. Aluminum, iron, manganese, and silicon did not have mismatched spike and native concentrations in the original MS. The original MS recovery for antimony was low, at $47 \%$. The antimony results in SDG K1207are qualified by third-party validation as estimates with "J" flags. Estimated data are useable for decision-making purposes.

Also in the ICP metals analysis, the LCS recovery for silicon is below the acceptance criteria at $6.2 \%$. The silicon data for SDG K1207 are qualified by third-party validation as estimates with "J" flags. Estimated data are useable for decision-making purposes.

\section{FIELD QUALITY ASSURANCE/QUALITY CONTROL}

RPD evaluations of main sample(s) versus the laboratory duplicate(s) are routinely performed and reported by the laboratory. Any deficiencies in those calculations are reported by SDG in the previous section.

Field QA/QC measures are used to assess potential sources of error and cross contamination of samples that could bias results. Field QA/QC samples, listed in the field logbook (WCH 2008a), consist of the primary and duplicate samples (J16MN5/J16MN6) collected from the base of the 600-111 excavation. The main and QA/QC sample results are presented in Appendix C.

Field duplicate samples are collected to provide a relative measure of the degree of local heterogeneity in the sampling medium, unlike laboratory duplicates that are used to evaluate precision in the analytical process. The field duplicates are evaluated by computing the RPD of the duplicate samples for each COC. The RPDs for the QA/QC samples are summarized below.

The RPD calculated for silicon was $30.3 \%$. The RPD calculated for chromium was $37.4 \%$. These RPDs exceeded the acceptance criteria of $30 \%$. Elevated RPD such as these in the analysis of environmental soil samples are largely attributed to heterogeneities in the soil matrix and only in small part attributed to precision and accuracy issues at the laboratory. The data are useable for decision-making purposes.

RPDs for the remaining analytes are not calculated because an examination of the data found that the analytes are not detected in both the main and duplicate sample at more than five times the target detection limit. RPDs of analytes detected at low concentrations (less than five times the detection limit) are not considered to be a useful indicator of heterogeneity in the sampling medium or the analytical system performance. The data are useable for decision making purposes.

A secondary check of the data variability is used when one or both of the samples being evaluated (main and duplicate or main and split) is less than five times the TDL, including undetected analytes. In these cases, a control limit of \pm 2 times the TDL is used (Appendix C) to indicate that a visual check of the 
data is required by the reviewer. A visual inspection of all of the data is also performed. No additional major or minor deficiencies are noted. The data are useable for decision-making purposes.

\section{SUMMARY}

Limited, random, or sample matrix-specific influenced batch QC issues such as those discussed above are a potential for any analysis. The number and types seen in these data sets are within expectations for the matrix types and analyses performed. The DQA of the 600-111 verification sampling data found that the analytical results are accurate within the standard errors associated with the analytical methods, sampling, and sample handling. Detection limits, precision, accuracy, and sampling data group completeness were assessed to determine if the data set is sufficient for decision-making purposes. The DQA concludes that the data are of the right type, quality, and quantity for decision-making purposes. The verification sample analytical data are stored in the ENRE project-specific database prior to being submitted for inclusion in the HEIS database. The verification sample analytical data are also summarized in Appendix C.

\section{REFERENCES}

BHI, 2000a, Data Validation Procedure for Chemical Analysis, BHI-01435, Rev. 0, Bechtel Hanford, Inc., Richland, Washington.

BHI, 2000b, Data Validation Procedure for Radiochemical Analysis, BHI-01433, Rev. 0, Bechtel Hanford, Inc., Richland, Washington.

BHI, 2004a, Final Validation Package, SAF-B03-015, SDG-H2584, Bechtel Hanford, Inc., Richland, Washington.

BHI, 2004b, Work Instruction for Waste Site 600-111, P-11 Critical Mass Laboratory Crib and Waste Site UPR-600-16, Fire and Contamination Spread, 0600X-WI-G0004, Rev. 0, Bechtel Hanford, Inc., Richland, Washington.

BHI-EE-01, Environmental Investigation Procedures, Bechtel Hanford, Inc., Richland, Washington.

DOE-RL, 2000, Sampling and Analysis Plan for the 100 Area Remaining Sites, DOE/RL-99-58, Rev. 0, U.S. Department of Energy, Richland Operations Office, Richland, Washington.

DOE-RL, 2005b, Remedial Design Report/Remedial Action Work Plan for the 100 Area, DOE/RL-96-17, Rev. 5, U.S. Department of Energy, Richland Operations Office, Richland, Washington.

DOE-RL, 2005a, 100 Area Remedial Action Sampling and Analysis Plan, DOE/RL-96-22, Rev. 4, U.S. Department of Energy, Richland Operations Office, Richland, Washington.

ENV-1-2, Environmental Monitoring \& Management, Part II, Environmental Investigations, Requests, and Field Screening, Washington Closure Hanford, Richland, Washington. 
EPA, 2000, Guidance for Data Quality Assessment, EPA QA/G-9, QA00 Update, U.S. Environmental Protection Agency, Office of Environmental Information, Washington, D.C.

WCH, 2008a, 100 F Remedial Sampling, Logbook EFL-1174-4, pp. 97-98, Washington Closure Hanford, Richland, Washington.

WCH, 2008b, Final Validation Package, SAF-RC-032, K1207, Washington Closure Hanford, Richland, Washington.

WCH, 2008c, Work Instruction for Verification Sampling of the 600-111 Septic Tank and Drain Field, 0600X-WI-G0015, Rev. 0, Washington Closure Hanford, Richland, Washington. 


\section{APPENDIX C}

\section{CALCULATIONS}




\section{APPENDIX C}

\section{CALCULATIONS}

The calculations in this appendix are kept in the active Washington Closure Hanford project files and are available upon request. When the project is completed, the file will be stored in a U.S. Department of Energy, Richland Operations Office, repository. This calculation has been prepared in accordance with ENG-1, Engineering Services, ENG-1-4.5, "Project Calculation," Washington Closure Hanford, Richland, Washington. The following calculations are provided in this appendix:

600-111 Septic System Cleanup Verification 95\% UCL Calculations, 0600X-CA-V0070, Rev. 1......C-1

600-111 and UPR-600-16 Waste Site Cleanup Verification Hazard Quotient and Carcinogenic Risk

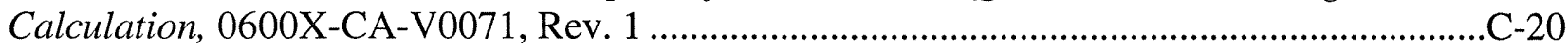

600-111, P-11 Critical Mass Laboratory RESRAD Calculation Brief, 0600X-CA-V0043, Rev. 0...C-25

\section{DISCLAIMER FOR CALCULATIONS}

The calculations provided in this appendix have been generated to document compliance with established cleanup levels. These calculations should be used in conjunction with other relevant documents in the administrative record. 


\section{CALCULATION COVER SHEET}

Project Title: 600 Area Field Remediation

Job No. 14655

Area: 600 Area; IU-6 Operable Unit

Discipline: Environmental

${ }^{*}$ Calculation No: 0600X-CA-V0070

Subject: $600-111$ Septic System Cleanup Verification $95 \%$ UCL Calculations

Computer Program: Excel

Program No: Excel 2003

The attached calculations have been generated to document compliance with established cleanup levels. These calculations should be used in conjunction with other relevant documents in the administrative record.

\section{Committed Calculation $\mathbb{Q} \quad$ Preliminary $\square \quad$ Superseded $\square \quad$ Voided $\square$}

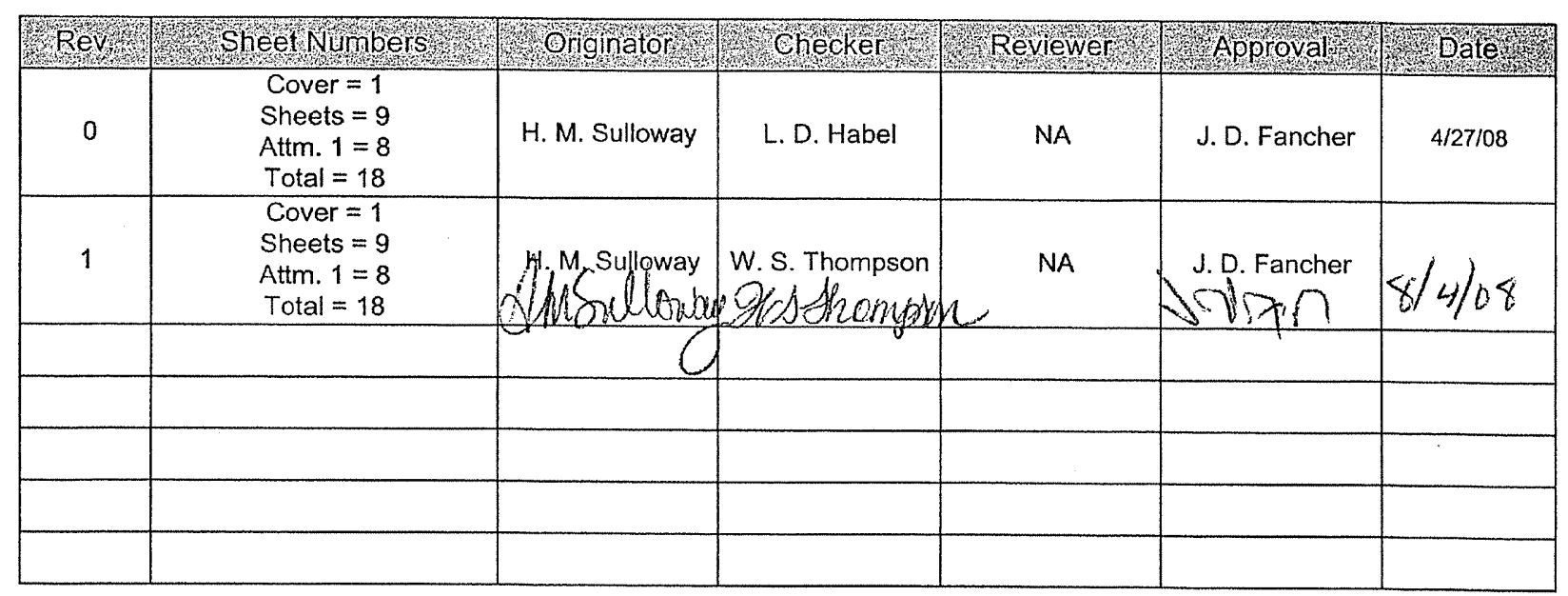

SUMMARY OF REVISION

\begin{tabular}{|l|l|}
\hline 1 & $\begin{array}{l}\text { Revision to clarify the 95\% UCL calculations apply only to verification samples collected after remediation } \\
\text { of the septic system located at the 600-111 waste site and not other 600-111 confirmatory sampled areas } \\
\text { or the UPR-600-16 waste site. All pages replaced as a result of changing the title. The first sentence of } \\
\text { the calculation description on Sheet } 1 \text { was revised to identify that verification sampling calculations apply } \\
\text { only to the septic tank, drain field, and interconnecting pipeline. }\end{array}$ \\
\hline
\end{tabular}


Sheets 1 to 3 - Calculation Sheet Summary

Sheet 4 to 5 - Calculation Sheet Shallow Zone Verification Data

Sheet 6 - Calculation Sheet Duplicate Analysis

Sheet 7 to 9 - Ecology Software (MTCAStat) Results

Attachment $1-600-111$ Verification Sampling Results (8 sheets)

Given/References:

1) Sample Results (Attachment 1).

2) Background values and remedial action goals (RAGs) are taken from DOE-RL (2005b), DOE-RL (2001), and Ecology (1996).

3) DOE-RL, 2001, Hanford Site Background: Part 1, Soil Background for Nonradioactive Analytes, DOE/RL-92-24, Rev. 4, U.S. Department of Energy, Richland Operations Office, Richland, Washington.

4) DOE-RL, 2005a, 100 Area Remedial Action Sampling and Analysis Plan (SAP), DOE/RL-96-22, Rev. 4, U.S. Department of Energy, Richland Operations Office, Richland, Washington.

5) DOE-RL, 2005b, Remedial Design Report/Remedial Action Work Plan for the 100 Area (RDR/RAWP), DOE/RL-96-17, Rev. 5, U.S. Department of Energy, Richland Operations Office, Richland, Washington.

6) Ecology, 1992, Statistical Guidance for Ecology Site Managers, Publication \#92-54, Washington Department of Ecology, Olympia, Washington.

7) Ecology, 1993, Statistical Guidance for Ecology Site Managers, Supplement S-6, Analyzing Site or Background Data with Below-detection Limit or Below-PQL Values (Censored Data Sets), Publication \#92-54, Washington Department of Ecology, Olympia, Washington.

8) Ecology, 1996, Model Toxic Control Act Cleanup Levels and Risk Calculations (CLARC II), Publication \#94-145, Washington State Department of Ecology, Olympia, Washington.

9) Ecology, 2005, Cleanup Levels and Risk Calculations (CLARC) Database, Washington State Department of Ecology, Olympia, Washington, <https://fortress.wa.gov/ecy/clarc/CLARCHome.aspx>.

10) EPA, 1994, USEPA Contract Laboratory Program National Functional Guidelines for Inorganic Data Review, EPA 540/R-4/013. U.S. Environmental Protection Agency, Washington, D.C.

11) WAC 173-340, 1996, "Model Toxic Control Act - Cleanup," Washington Administrative Code.

Solution:

Calculation methodology is described in Ecology Pub. \#92-54 (Ecology 1992, 1993), below, and in the RDR/RAWP (DOE-RL 2005b) Use data from attached worksheets to perform the $95 \%$ UCL calculation for each analyte, the WAC 173-340-740(7)(e) 3-part test for nonradionuclides, and the RPD calculations for each COC/COPC. The hazard quotient and carcinogenic risk calculations are located in a separate calculation brief as an appendix to the Remaining Sites Verification Package (RSVP).

Calculation Description:

The subject calculations were performed on data from soil verification samples (Attachment 1) collected after remediation of the 600-111 septic system (septic tank, septic drain field and inteconnecting pipeline). The data were entered into an EXCEL 2003 spreadsheet and calculations performed by using the built-in spreadsheet functions and/or creating formulae within the cells. The statistical evaluation of data for use in accordance with the RDR/RAWP (DOE-RL 2005b) is documented by this calculation.

Duplicate RPD results are used in evaluation of data quality within the RSVP for this site. 
Washington Closure Hanford

Originator H.M. Sulloway
Project
Subject

\section{CALCULATION SHEET}

Calc. No. 0600X-CA-V0070 Checked W. S. Thompsongly

Rev. No Sheet No. $\frac{080}{2 \text { of } 9}$

1 Summary (continued)

2 Methodology:

3 For nonradioactive analytes with $\leq 50 \%$ of the data below detection limits, the statistical value calculated to evaluate the effectiveness of

4 cleanup is the $95 \%$ UCL. For nonradioactive analytes with $>50 \%$ of the data below detection limits, as determined by direct inspection

5 of the sample results (Attachment 1), the maximum detected value for the data set is used instead of the $95 \%$ UCL, and no further

7 calculations are performed for those data sets. For convenience, these maximum detected values are included in the summary tables

that follow. The $95 \%$ UCL was not calculated for data sets with no reported detections. Calculated cleanup levels are not available in

9 Ecology (2005) under WAC 173-340-740(3) for aluminum, calcium, iron, magnesium, potassium, silicon, and sodium; therefore, these

10 constituents are not considered site COCs/COPCs and are also not included in these calculations.

All nonradionuclide data reported as being undetected are set to $1 / 2$ the detection limit value for calculation of the statistics (Ecology 1993). In cases where the laboratory does not report a value below the minimal detectable activity (MDA), half of the MDA is used in after adjustments for censored data as described above.

For nonradionuclides, the WAC 173-340 statistical guidance suggests that a test for distributional form be performed on the data and the $95 \%$ UCL calculated on the appropriate distribution using Ecology software. For nonradionuclide small data sets $(n<10)$, the calculations are performed assuming nonparametric distribution, so no tests for distribution are performed. For nonradionuclide data sets of ten or greater, as for the subject site, distributional testing is done using Ecology's MTCAStat software (Ecology 1993). Due to differences in addressing censored data between the RDR/RAWP (DOE-RL 2005b) and MTCAStat coding and due to a limitation in the MTCAStat coding (no direct capability to address variable quantitation limits within a data set), substitutions for censored data are performed before software input and the resulting data set treated as uncensored.

The WAC 173-340-740(7)(e) 3-part test is performed for nonradionuclide analytes only and determines if:

1) the $95 \%$ UCL exceeds the most stringent cleanup limit for each COPC/COC,

2) greater than $10 \%$ of the raw data exceed the most stringent cleanup limit for each $\mathrm{COPC} / \mathrm{COC}$,

3) the maximum value of the raw data set exceeds two times the most stringent cleanup limit for each COPC/COC.

The RPD is calculated when both the primary value and the duplicate value for a given analyte are above detection limits and are greater than 5 times the target detection limit (TDL). The TDL is a laboratory detection limit pre-determined for each analytical method and is listed in Table II-1 of the SAP (DOE-RL 2005a). Where direct evaluation of the attached sample data showed that a given analyte was not detected in the primary and/or duplicate sample, further evaluation of the RPD value was not performed. The RPD calculations use the following formula:

$$
\mathrm{RPD}=[|\mathrm{M}-\mathrm{S}| /((\mathrm{M}+\mathrm{S}) / 2)]^{*} 100
$$

where, $M=$ Main Sample Value

$$
S=\text { Split (or duplicate) Sample Value }
$$

For quality assurance/quality control (QA/QC) split and duplicate RPD calculations, a value less than $30 \%$ indicates the data compare favorably. For regulatory splits, a threshold of $35 \%$ is used (EPA 1994). If the RPD is greater than $30 \%$ (or $35 \%$ for regulatory split data), further investigation regarding the usability of the data is performed. No split samples were collected for cleanup verification of the subject site. Additional discussion as necessary is provided in the data quality assessment section of the applicable RSVP. 
Washington Closure Hanford

Originator H. M. Sulloway old $\mathrm{N}$

Project 600 Area Field Remediation

Subject 600-111 Septic System Cleanup Verification $95 \%$

\section{CALCULATION SHEET}

Date $08 / 03 / 08$

Calc. No. 0600X-CA-V0070 Checked W.S. Thompson $\begin{aligned} \text { Rev. No. } & \frac{1}{08 / 03 / 08} \\ \text { Date } & \frac{08 \text { of } 9}{\text { Sheet No. }}\end{aligned}$

1 Summary (continued)

2 Results:

3 The results presented in the tables that follow include the summary of the results of the $95 \%$ UCL calculations for the shallow zone

4 excavation, the WAC 173-340-740(7)(e) 3-part test evaluation, and the RPD calculations, and are for use in risk analysis and the RSVP for 5 this site.

6

\begin{tabular}{|c|c|c|c|}
\hline \multicolumn{4}{|c|}{ Results Summary - Shallow Zone Excavation } \\
\hline Analyte & $\begin{array}{c}95 \% \text { UCL } \\
\text { Result }^{\mathrm{a}}\end{array}$ & $\begin{array}{c}\text { Maximum } \\
\text { Value }^{\mathrm{a}}\end{array}$ & Units \\
\hline Arsenic & 5.6 & & $\mathrm{mg} / \mathrm{kg}$ \\
\hline Barium & 154 & & $\mathrm{mg} / \mathrm{kg}$ \\
\hline Beryllium & 0.97 & & $\mathrm{mg} / \mathrm{kg}$ \\
\hline Chromium & 11.6 & & $\mathrm{mg} / \mathrm{kg}$ \\
\hline Cobalt & 10.6 & & $\mathrm{mg} / \mathrm{kg}$ \\
\hline Copper & 22.8 & & $\mathrm{mg} / \mathrm{kg}$ \\
\hline Lead & 12.7 & & $\mathrm{mg} / \mathrm{kg}$ \\
\hline Manganese & 501 & & $\mathrm{mg} / \mathrm{kg}$ \\
\hline Molybdenum & 1.0 & & $\mathrm{mg} / \mathrm{kg}$ \\
\hline Nickel & 14.5 & & $\mathrm{mg} / \mathrm{kg}$ \\
\hline Vanadium & 75.9 & & $\mathrm{mg} / \mathrm{kg}$ \\
\hline Zinc & 61.6 & & $\mathrm{mg} / \mathrm{kg}$ \\
\hline Bis (2-ethylhexyl) phthalate & 0.088 & & $\mathrm{mg} / \mathrm{kg}$ \\
\hline Antimony & & 1.2 & $\mathrm{mg} / \mathrm{kg}$ \\
\hline Boron & & 1.2 & $\mathrm{mg} / \mathrm{kg}$ \\
\hline Mercury & & 0.030 & $\mathrm{mg} / \mathrm{kg}$ \\
\hline Isophorone & & 0.020 & $\mathrm{mg} / \mathrm{kg}$ \\
\hline Pyrene & & 0.018 & $\mathrm{mg} / \mathrm{kg}$ \\
\hline \multicolumn{4}{|c|}{ WAC 173-340-740(7)(e) Evaluation: } \\
\hline $95 \%$ UCL > Cleanup Limit? & YES & & \\
\hline | $>10 \%$ above Cleanup Limit? & YES & & \\
\hline Any sample $>2 x$ Cleanup Limit? & YES & & \\
\hline
\end{tabular}

36 as described in the methodology section.

37

38

39

40

41

42

43

44

45

46

47

48

49

50

51

52

53

\begin{tabular}{|l|c|}
\hline \multicolumn{2}{|c|}{$\begin{array}{c}\text { Relative Percent Difference Results } \\
\text { QA/QC Analysis }\end{array}$} \\
\hline \multicolumn{1}{|c|}{ Analyte } & $\begin{array}{c}\text { Duplicate } \\
\text { Analysis }\end{array}$ \\
\hline Aluminum & $24.0 \%$ \\
\hline Barium & $18.6 \%$ \\
\hline Calcium & $5.3 \%$ \\
\hline Chromium & $37.4 \%$ \\
\hline Copper & $10.9 \%$ \\
\hline Iron & $10.4 \%$ \\
\hline Magnesium & $17.0 \%$ \\
\hline Manganese & $18.3 \%$ \\
\hline Silicon & $30.3 \%$ \\
\hline Vanadium & $10.9 \%$ \\
\hline Zinc & $14.5 \%$ \\
\hline
\end{tabular}

${ }^{b}$ Relative percent difference evaluation was not required for analytes not included in this table.

'These values are discussed in the RSVP.

Abbreviations/Acronyms:

The following abbreviations and/or acronyms are used in this calculation:

$\mathrm{B}=$ blank contamination (organics)

$B G=$ background

$\mathrm{C}=$ blank contamination (inorganics)

$\mathrm{COC}=$ contaminant of concern

$\mathrm{COPC}=$ contaminant of potential concern

$\mathrm{D}=$ analyte was identified in an analysis at a secondary dilution factor

$D E=$ direct exposure

$\mathrm{GW}=$ groundwater

$\mathrm{J}=$ estimate

MDA = minimal detectable activity

MTCA = Model Toxics Control Act

$P Q L=$ practical quantitation limit

$Q=$ qualifier

$Q A Q C=$ quality assurance/quality control

$R A G=$ remedial action goal

RDR/RAWP = remedial design report/remedial action work plan

RESRAD = RESidual RADioactivity (dose model)

$R P D=$ relative percent difference

RSVP = remaining sites verification package

SAP = sampling and analysis plan

$T D L=$ target detection limit

$U=$ undetected

$\mathrm{UCL}=$ upper confidence limit

WAC $=$ Washington Administrative Code 
Washington Closure Hanford

Originator H. M. Sulloway $d \mathrm{l} \ln B$

Subject $600-111$ Septic System Clean
CALCULATION SHEET

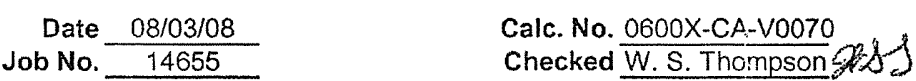

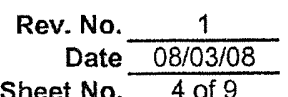

1 600-111 Excavation Shallow Zone Statistical Calculations

\begin{tabular}{|c|c|c|c|c|c|c|c|c|c|c|c|c|c|c|c|c|c|c|c|c|c|}
\hline \multirow{2}{*}{\begin{tabular}{|}
$\mid \begin{array}{l}\text { Sample } \\
\text { Area }\end{array}$ \\
5
\end{tabular}} & \multirow{2}{*}{\begin{tabular}{|l|} 
Sample \\
Number
\end{tabular}} & \multirow{2}{*}{$\begin{array}{c}\begin{array}{c}\text { Sample } \\
\text { Date }\end{array} \\
4 / 21108\end{array}$} & \multicolumn{3}{|c|}{$\begin{array}{l}\text { Arsenic } \\
\end{array}$} & \multicolumn{2}{|c|}{ Barium } & \multicolumn{2}{|c|}{$\begin{array}{l}\text { Beryllium } \\
\end{array}$} & \multicolumn{3}{|c|}{ Chromium } & \multicolumn{3}{|c|}{ Cobalt } & \multicolumn{3}{|c|}{ Copper } & \multicolumn{3}{|c|}{ Lead } \\
\hline & & & $\frac{\mathrm{mg} / \mathrm{kg}}{7}$ & $Q$ & $P Q L$ & $\mathrm{mg} / \mathrm{kg}$ & \begin{tabular}{|l|l}
$Q$ & $P Q L$ \\
\end{tabular} & $\mathrm{mg} / \mathrm{kg}$ & \begin{tabular}{l|l}
$Q$ & $P Q L$ \\
\end{tabular} & $\mathrm{mg} / \mathrm{kg}$ & & $\mathrm{PQL}$ & $\mathrm{mg} / \mathrm{kg}$ & & $\begin{array}{l}P Q L \\
\end{array}$ & $\mathrm{mg} / \mathrm{kg}$ & & $P Q L$ & $\mathrm{mg} / \mathrm{kg}$ & & PQL \\
\hline Duplicate of & & & & & & & 0.23 & 0.93 & 0.11 & 12.7 & & 0.46 & 10.3 & & 0.46 & 23.2 & $c$ & 0.52 & 21.4 & & 0.68 \\
\hline J16MN5 & J16MN6 & $4 / 21 / 08$ & 5 & & 1.4 & 107 & 0.29 & 0.82 & 0.14 & 8.7 & & 0.58 & 9.1 & & 0.58 & & c & 0.66 & & & \\
\hline 1 & J16MM8 & $4 / 21 / 08$ & 4.2 & & 1.3 & 151 & 0.25 & 0.73 & 0.13 & 12.0 & & 0.5 & 8.6 & & 0.5 & 15.6 & c & 0.58 & 8.9 & & 0.76 \\
\hline 2 & J16MM9 & $4 / 21 / 08$ & 1.7 & & 1.3 & 168 & 0.24 & 1.1 & 0.13 & 10.0 & & 0.51 & 11.2 & & 0.51 & 26.5 & c & 0.58 & 5.2 & & 0.76 \\
\hline$\frac{3}{4}$ & J16MNO & $\frac{4 / 21108}{4121108}$ & 4.1 & & 1.2 & 170 & 0.23 & 0.92 & 0.12 & 12.0 & & 0.46 & 11.4 & & 0.46 & 23.3 & $c$ & 0.53 & 7.2 & & 0.70 \\
\hline$\frac{4}{5}$ & $\begin{array}{l}\frac{J 16 M N 1}{J 16 M N 2} \\
\text { J16 }\end{array}$ & $\begin{array}{l}4 / 21 / 108 \\
4 / 21 / 88\end{array}$ & $\frac{3.3}{36}$ & & $\frac{1.2}{0.00}$ & 137 & 0.25 & 1.10 & 0.12 & 9.4 & & 0.5 & 11.6 & & 0.5 & 24.0 & $c$ & 0.57 & 6.0 & & 0.75 \\
\hline$\frac{5}{6}$ & $\begin{array}{l}\frac{J 16 \mathrm{MNN} 2}{\mathrm{~J} 16 \mathrm{MN} 3} \\
\end{array}$ & $4 \frac{4 / 21 / 1108}{4 / 108}$ & $\frac{3.6}{2.8}$ & & $\frac{0.98}{12}$ & 156 & 0.2 & 0.84 & 0.1 & 10.3 & & 0.39 & 9.7 & & 0.39 & 20.0 & $c$ & 0.45 & 8.3 & & 0.59 \\
\hline 7 & J16MN4 & $4 / 21 / 08$ & $\frac{6.0}{6.6}$ & & 1.3 & 91.4 & 0.25 & 0.88 & 0.13 & 8.2 & & 0.51 & 9.8 & & 0.51 & 15.9 & $c$ & 0.58 & 2.9 & & 0.76 \\
\hline 9 & J16MN7 & $4 / 2108$ & 6.1 & & 1.4 & 128 & 0.28 & 0.8 & 0.14 & 12.7 & & 0.55 & 9.1 & & 0.55 & 18.7 & C & 0.64 & 11.1 & & 0.83 \\
\hline 10 & J16MN8 & $4 / 21 / 08$ & 2.8 & & $\frac{1.3}{1.4}$ & $\frac{126}{018}$ & 0.25 & 0.75 & 0.13 & 11.3 & & 0.5 & 9.7 & & 0.5 & 20.3 & $c$ & 0.58 & 11.0 & & 0.75 \\
\hline & & & & & 1.4 & 94.8 & 0.28 & 0.88 & 0.14 & 7.4 & & 0.56 & 9.3 & & 0.56 & 17.6 & $c$ & 0.64 & 4.1 & & 0.83 \\
\hline
\end{tabular}

16 Statistical Computation Input Data

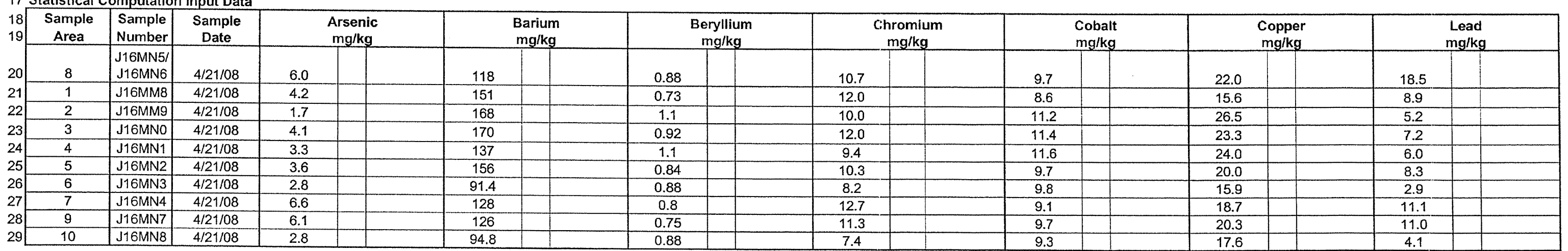

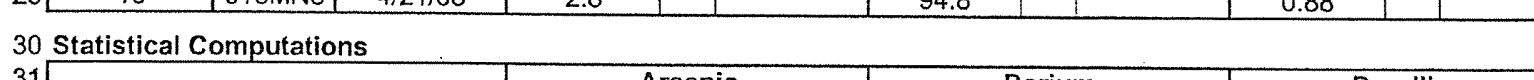

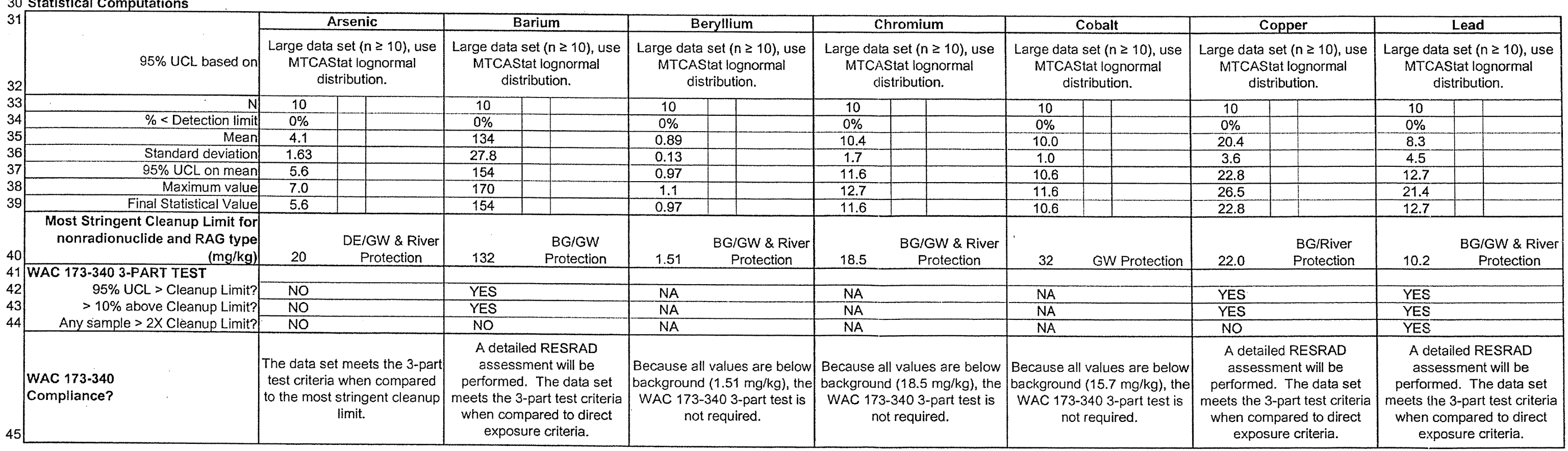


Washington Closure Hanford

Originator H.M. Sulloway des

Project
Subject 600 Area 111 Septic System Cleanup Verification $95 \%$ UCL Calculation
CALCULATION SHEET

Date $08 / 03 / 08$
Job No. $\frac{14655}{}$
Calc. No. $0600 X-C A-V 0070$
Checked W. S. Thompson
Rev. No. $\frac{1}{\text { Date }}$
Sheet No.
$08 / 03 / 08$
5 of 9

\begin{tabular}{|c|c|c|c|c|c|c|c|c|c|c|c|c|c|c|c|c|c|c|c|}
\hline \multirow[t]{3}{*}{ 3] } & \multirow{3}{*}{\begin{tabular}{|c|}
$\begin{array}{c}\text { Sample } \\
\text { Area }\end{array}$ \\
8 \\
\end{tabular}} & \multirow{3}{*}{\begin{tabular}{|l} 
Sample \\
Number \\
$16 \mathrm{MN5}$ \\
\end{tabular}} & \multirow{3}{*}{ 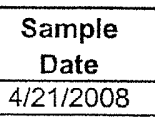 } & \multicolumn{3}{|c|}{ Manganese } & \multicolumn{3}{|c|}{ Molybdenum } & \multicolumn{2}{|c|}{ Nickel } & \multicolumn{3}{|c|}{ Vanadium } & \multicolumn{2}{|c|}{ Zinc } & \multicolumn{3}{|c|}{ Bis(2-ethylhexyl) phthalate } \\
\hline & & & & $\mathrm{mg} / \mathrm{kg}$ & Q & $\mathrm{PQL}$ & $\mathrm{mg} / \mathrm{kg}$ & Q & PQL & $\mathrm{mg} / \mathrm{kg}$ & $\mathrm{PQL}$ & $m g / k g$ & $Q$ & $\mathrm{PQL}$ & $\mathrm{mg} / \mathrm{kg}$ & $\mathrm{PQL}$ & $\mathrm{mg} / \mathrm{kg}$ & Q & $\mathrm{PQL}$ \\
\hline & & & & 441 & C & 0.090 & 0.96 & & 0.68 & 16.0 & 0.46 & 69.6 & & 0.32 & 66.7 & 1.4 & 0.026 & & \\
\hline & J16MN5 & J16MN6 & $4 / 21 / 2008$ & 367 & $c$ & 0.12 & & $u$ & 0.87 & 118 & & & & & & & & & \\
\hline & 1 & J16MM8 & $4 / 21 / 2008$ & 420 & c & 0.10 & 0.76 & $\frac{u}{u}$ & 0.76 & $\frac{11.0}{131}$ & $\frac{0.08}{0.50}$ & $\frac{62.4}{56.6}$ & & $\frac{0.40}{0.35}$ & $\frac{51.1}{524}$ & $\frac{1.1}{15}$ & 0.017 & $\frac{1}{2}$ & 0.35 \\
\hline 8 & 2 & J16MM9 & $4 / 21 / 2008$ & 438 & C & 0.10 & $\frac{0.10}{1.3}$ & 0 & 0.76 & $\frac{13.1}{14.9}$ & $\frac{0.50}{0.51}$ & 56.6 & & 0.35 & $\frac{52.4}{65.8}$ & $\frac{1.5}{1.5}$ & 0.021 & $\frac{2}{3}$ & $\frac{0.35}{0.35}$ \\
\hline 9 & 3 & J16MNO & $4 / 21 / 2008$ & 527 & C & 0.090 & 0.86 & & 0.70 & 14.7 & 0.46 & $\frac{11.1}{76.1}$ & & 0.33 & $\frac{00.6}{61.6}$ & $\frac{\frac{1.5}{1.4}}{1.4} \mathrm{l} \mathrm{x}$ & 0.032 & $\frac{2}{3}$ & 0.34 \\
\hline 10 & 4 & J16MN1 & $4 / 21 / 2008$ & 703 & c & 0.10 & 1.1 & & 0.75 & 15.0 & 0.50 & 80.5 & & 0.35 & 64.1 & $\frac{1.4}{1.5}$ & 0.004 & $\bar{U}$ & 0.044 \\
\hline & 5 & J16MN2 & $4 / 21 / 2008$ & 424 & c & 0.080 & 1.0 & & 0.59 & 12.9 & 0.39 & 63.6 & & 0.28 & 60.7 & 1.2 & 0.025 & $\mathrm{~J}$ & 0.34 \\
\hline & 6 & J16MN3 & 4/21/2008 & 391 & c & 0.10 & 0.94 & & 0.76 & 9.4 & 0.51 & 76.1 & & 0.36 & 54.0 & 1.5 & 0.018 & $\mathrm{~J}$ & 0.35 \\
\hline & 7 & 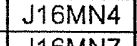 & $4 / 21 / 2008$ & 428 & c & 0.11 & 0.83 & $U$ & 0.83 & 14.8 & 0.55 & 65.7 & & 0.39 & 56.3 & 1.7 & 0.020 & $\mathrm{~J}$ & 0.36 \\
\hline & $\frac{9}{10}$ & J16MN7 & $44 / 21 / 2008$ & 391 & \begin{tabular}{l|l} 
C & \\
\end{tabular} & 0.10 & $\frac{1.1}{0.82}$ & -1 & 0.75 & 14.7 & 0.50 & 66.6 & & 0.35 & 55.1 & 1.5 & 0.34 & $\mathrm{U}$ & 0.34 \\
\hline & & & & & & & & U & & & 0.56 & 70.0 & & 0.39 & 54.5 & 1.7 & 0.062 & & 0.35 \\
\hline \multicolumn{20}{|c|}{17 Statistical Computation Input Data } \\
\hline $\begin{array}{l}18 \\
19\end{array}$ & \begin{tabular}{|c|} 
Sample \\
Area
\end{tabular} & \begin{tabular}{|l|} 
Sample \\
Number
\end{tabular} & $\begin{array}{c}\text { Sample } \\
\text { Date }\end{array}$ & \multicolumn{3}{|c|}{$\begin{array}{c}\text { Manganese } \\
\mathrm{mg} / \mathrm{kg} \\
\end{array}$} & \multicolumn{3}{|c|}{$\begin{array}{c}\text { Molybdenum } \\
\mathrm{mg} / \mathrm{kg}\end{array}$} & \multicolumn{2}{|c|}{$\begin{array}{l}\text { Nickel } \\
\mathrm{mg} / \mathrm{kg}\end{array}$} & \multicolumn{3}{|c|}{$\begin{array}{c}\text { Vanadium } \\
\mathrm{mg} / \mathrm{kg}\end{array}$} & \multicolumn{2}{|c|}{$\begin{array}{l}\text { Zinc } \\
\text { malko }\end{array}$} & \multicolumn{3}{|c|}{\begin{tabular}{|c|} 
Bis(2-ethylhexyl) phthalate \\
$\mathrm{mg} / \mathrm{kg}$
\end{tabular}} \\
\hline 20 & 8 & J16MN5! & 102108 & 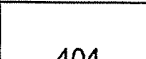 & & & 070 & & & 1000 & & 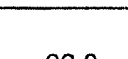 & & & $\operatorname{mos} 90$ & & & & \\
\hline 21 & $\frac{0}{1}$ & J16MM8 & 4/21/100 & $\frac{404}{420}$ & & & 0.38 & & & $\frac{13.9}{131}$ & & $\frac{66.0}{56.6}$ & & & $\frac{62.2}{524}$ & & 0.022 & & \\
\hline & 2 & J16MM9 & $4 / 21 / 08$ & 438 & & & 1.3 & & & 14.9 & & $\frac{77.1}{77 .}$ & & & 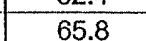 & & 0.0219 & & \\
\hline & 3 & J16MNO & $4 / 21 / 08$ & 527 & & & 0.86 & & & 14.7 & & 76.1 & & & 61.6 & & & & \\
\hline & 4 & J16MN1 & $4 / 21 / 08$ & 703 & & & 1.1 & & & 15.0 & & 86.5 & & & 64.1 & & & & \\
\hline & 5 & J16MN2 & $4 / 21 / 08$ & 424 & & & 1.0 & & & 12.9 & & 63.6 & & & 60.7 & & & & \\
\hline & 6 & J16MN3 & $4 / 21$ & 391 & & & 0.94 & & & 9.4 & & 76.1 & & & 54.0 & & & & \\
\hline & 7 & J16MN4 & $4 / 21$ & 428 & & & 0.42 & & & 14.8 & & 65.7 & & & 56.3 & & & & \\
\hline & 9 & J16MN7 & & 391 & & & 1.1 & & & 14.7 & & 66.6 & & & 55.1 & & 0.17 & & \\
\hline & 10 & $116 \mathrm{MNB}$ & $4 / 21 / 08$ & 374 & & & 0.42 & & & 11.7 & & 70.0 & & & 54.5 & & 0.062 & & \\
\hline \multirow{2}{*}{\multicolumn{20}{|c|}{ Bis(2-thylhexvl) phthalate }} \\
\hline & & & & & & bdet & & & Nickel & & Janad & & & Zinc & Bis(2-ethyl & Ihexy & 1) phthalate \\
\hline & & & & $\begin{array}{c}\text { Large da } \\
\text { lognorm } \\
\text { distributic } \\
z-\end{array}$ & $\begin{array}{l}\text { ta set } \\
\text { al and } \\
\text { on rejec } \\
\text { statisti }\end{array}$ & $\begin{array}{l}n \geq 10), \\
\text { normal } \\
\text { ted, use } \\
\text { t. use }\end{array}$ & $\begin{array}{r}\text { Large data } \\
\text { MTCA } \\
\text { dis }\end{array}$ & $\begin{array}{l}\text { set }(r) \\
\text { Stat }\end{array}$ & $\begin{array}{l}\geq 10) \text {, use } \\
\text { ormal } \\
\text { on. }\end{array}$ & $\begin{array}{c}\text { Large dc } \\
\text { lognorn } \\
\text { distributic } \\
z\end{array}$ & $\begin{array}{l}\text { ta set }(n \geq 10) \text {, } \\
\text { al and normal } \\
\text { in rejected, use } \\
\text { statistic. }\end{array}$ & $\begin{array}{l}\text { Large d } \\
\text { MTC }\end{array}$ & $\begin{array}{l}\text { ta set } \\
\text { Astat I } \\
\text { istribu }\end{array}$ & $\begin{array}{l}\text { 210), use } \\
\text { normal } \\
\text { n. }\end{array}$ & $\begin{array}{c}\text { Large date } \\
\text { MTCA } \\
\text { di }\end{array}$ & $\begin{array}{l}\text { set }(n \geq 10) \text {, use } \\
\text { tat lognormal } \\
\text { iribution. }\end{array}$ & $\begin{array}{r}\text { Large da } \\
\text { lognorm } \\
\text { distributio } \\
z-8\end{array}$ & $\begin{array}{l}\text { ata set } \\
\text { nal an } \\
\text { on reje } \\
\text { statis }\end{array}$ & $\begin{array}{l}n \geq 10) \\
\text { normal } \\
\text { ted, use }\end{array}$ \\
\hline 34 & & & $\mathrm{~N}$ & $10^{2}$ & & & 10 & & & 10 & 1 & 10 & - & & 10 & & 10 & 1 & \\
\hline $\begin{array}{l}35 \\
36\end{array}$ & & & $\begin{array}{c}\text { etection limith } \\
\text { Mean }\end{array}$ & $\frac{0 \%}{450}$ & & & $\frac{30 \%}{082}$ & & & $0 \%$ & t & $0 \%$ & & & $\begin{array}{l}0 \% \\
587 \\
87\end{array}$ & & 0.20 & & \\
\hline 37 & & Stan & ard deviation & $\begin{array}{l}450 \\
98.3 \\
98\end{array}$ & & & 0.82 & & & $\frac{713.5}{1.81}$ & & $\frac{10.4}{8.6}$ & & & $\frac{58.7}{4.7}$ & & & & \\
\hline & & $95 \%$ & JCL on mean & 501 & & & 1.0 & & & 14.5 & & & & & 61.6 & & & & \\
\hline & & & & 703 & & & 1.3 & & & 16.0 & & 86.5 & & & 66.7 & & 0.062 & & \\
\hline & & Final St & 1e) & 501 & $L$ & & 1.0 & & & 14.5 & & 75.9 & & & 61.6 & & 0.088 & & \\
\hline & $\begin{array}{l}\text { Most Strin } \\
\text { nonradic }\end{array}$ & $\begin{array}{l}\begin{array}{l}\text { ngent Clea } \\
\text { ionuclide a }\end{array} \\
\text { a }\end{array}$ & nup Limit for & & & V \& River & & & & & $3 \mathrm{G} / \mathrm{GW}$ & & & & & BG/River & & & \\
\hline & WAC 173-3. & 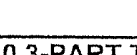 & (mg/kg) & 512 & & ection & 8 & & Protection & 19.1 & Protection & 85.1 & BG/ & N Protection & 67.8 & & 0.36 & Rive & er Protection \\
\hline 43 & & & & NO & & & NO & & & $\mathrm{N}$ & & $\mathrm{N}$ & & & $\mathrm{NA}$ & & NO & & \\
\hline $44 \mid$ & & & & YES & & & NO & & & $\mathrm{NA}$ & & NO & & & NA & & NO & & \\
\hline & Any sam & mple $>2 \times c$ & eanup Limit?] & NO & & & NO & & & NA & & NO & & & NA & & NO & & \\
\hline & $\begin{array}{l}\text { WAC 173-340 } \\
\text { Compliance? }\end{array}$ & & & $\begin{array}{l}\text { A deta } \\
\text { asses } \\
\text { performe } \\
\text { meets the } \\
\text { when cor } \\
\text { expos }\end{array}$ & $\begin{array}{l}\text { led RE } \\
\text { ement } \\
\text { d. The } \\
\text { s-part } \\
\text { pured } \\
\text { ure cri }\end{array}$ & $\begin{array}{l}\text { SRAD } \\
\text { vill be } \\
\text { data set } \\
\text { est criteria } \\
\text { to direct } \\
\text { teria. }\end{array}$ & $\begin{array}{l}\text { The data se } \\
\text { test criteria } \\
\text { to the most }\end{array}$ & & $\begin{array}{l}\text { s the 3-part } \\
\text { compared } \\
\text { ent cleanup }\end{array}$ & $\begin{array}{r}\text { Because al } \\
\text { backgrounc } \\
\text { WAC 173- } \\
\text { not }\end{array}$ & $\begin{array}{l}\text { values are below } \\
(19.1 \mathrm{mg} / \mathrm{kg}) \text {, the } \\
340 \text { 3-part test is } \\
\text { required. }\end{array}$ & $\begin{array}{l}\text { The data } \\
\text { test criter } \\
\text { the most }\end{array}$ & & $\begin{array}{l}\text { s the 3-part } \\
\text { compared to } \\
\text { cleanup limit. }\end{array}$ & $\begin{array}{r}\text { Because a } \\
\text { backgroun } \\
\text { WAC 173 } \\
\text { no }\end{array}$ & $\begin{array}{l}\text { values are below } \\
(67.8 \mathrm{mg} / \mathrm{kg}) \text {, the } \\
340 \text {-part test is } \\
\text { required. }\end{array}$ & $\begin{array}{l}\text { The data se } \\
\text { test criteria } \\
\text { the most } 5\end{array}$ & $\begin{array}{l}\text { et mee } \\
\text { when } \\
\text { string } \\
\text { limit. }\end{array}$ & $\begin{array}{l}\text { ts the 3-part } \\
\text { compared to } \\
\text { ent cleanup }\end{array}$ \\
\hline
\end{tabular}


$\frac{\text { Washington Closure Hanford }}{\text { Originator H. M. Sulloway Hewe }}$

Subject $600-111$ Septic System Cleanup Verification $95 \%$ UCL Calculations

\section{CALCULATION SHEET}

$$
\begin{aligned}
\text { Date } \frac{08 / 03 / 08}{14655} & \text { Calc. No. } 0600 \text { X-CA-V0070 } \\
\text { Job No. } & \text { Checked W. S. Thompson }
\end{aligned}
$$

Rev. No. $\frac{1}{0810308}$ Sheet No. $\frac{08 \text { of } 9}{6}$

1 Duplicate Analysis

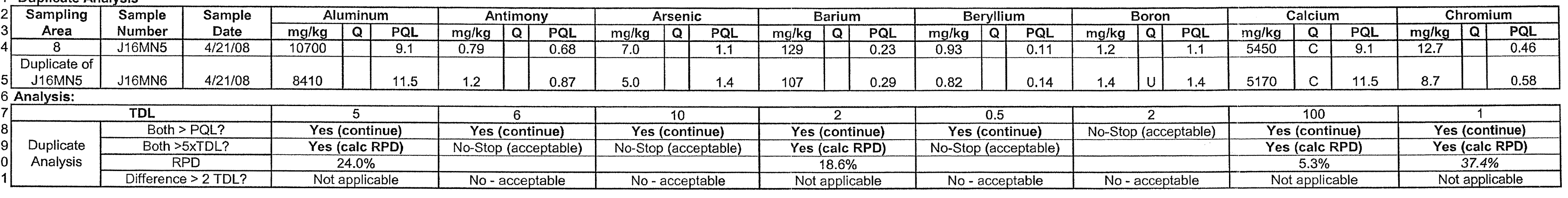

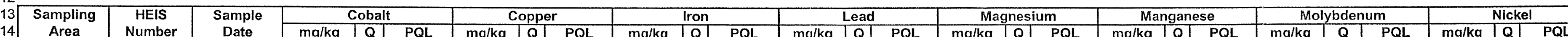

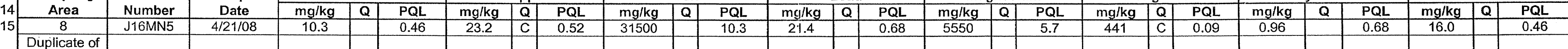

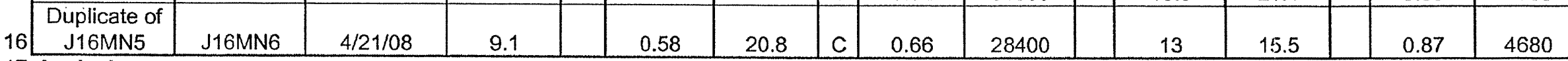

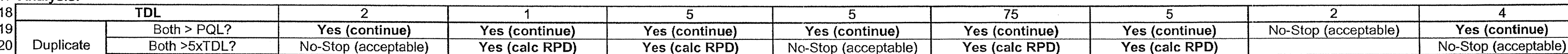

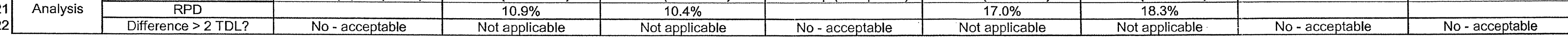

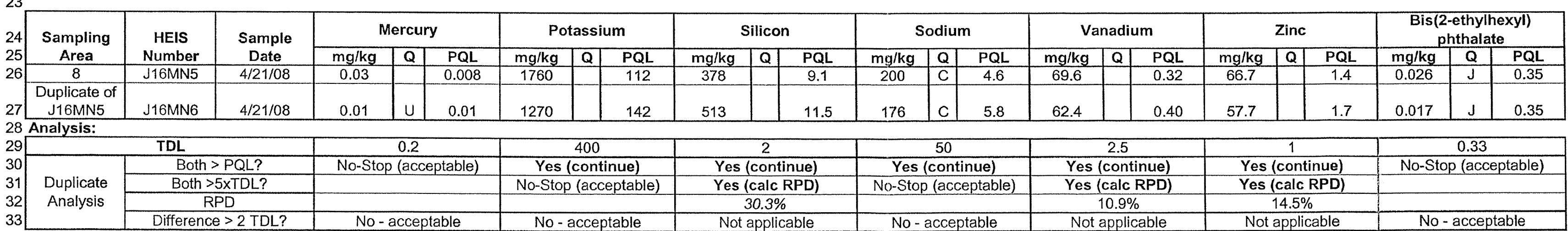




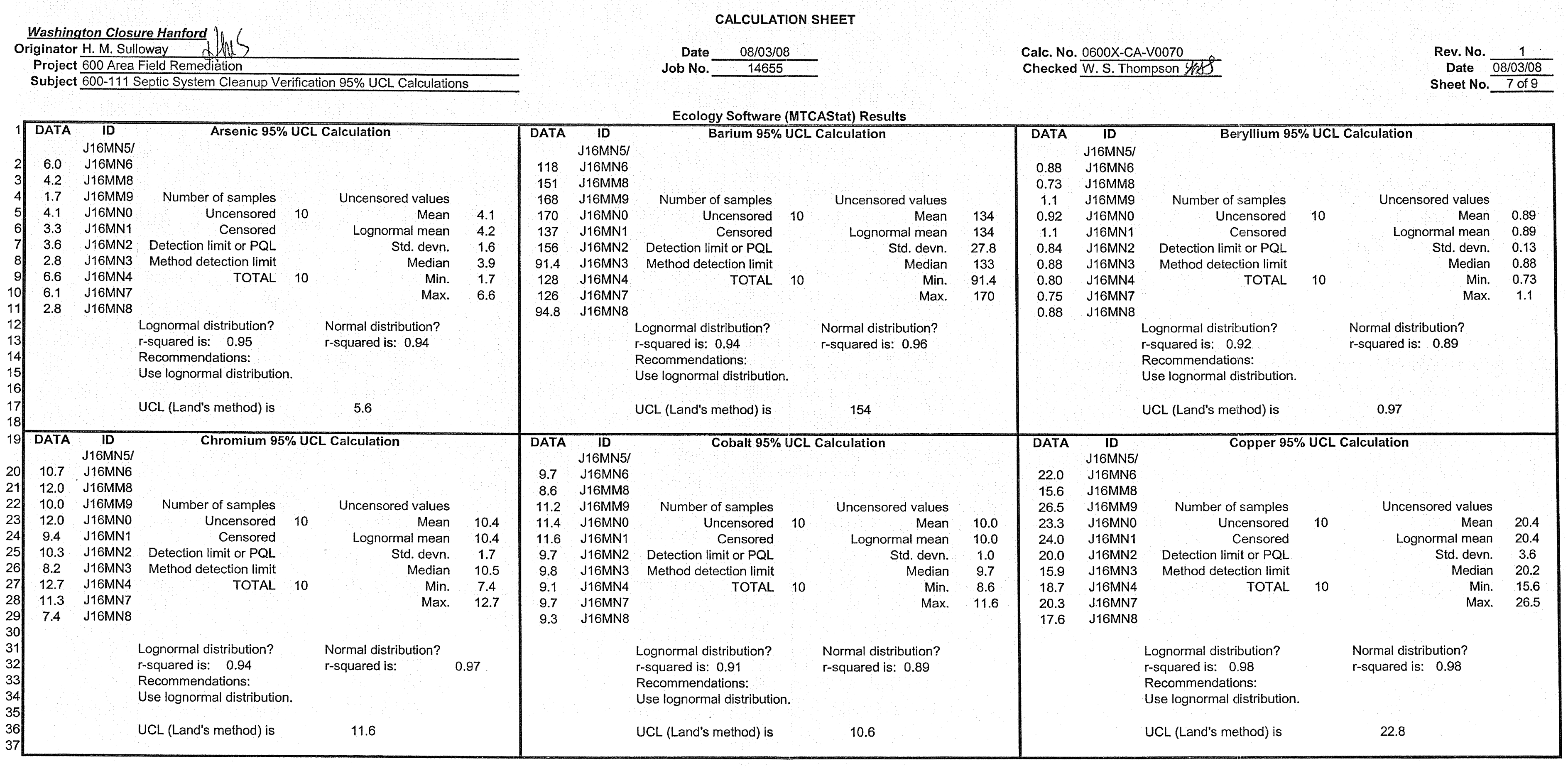


Washington Closure Hanford

Project M. Sulloway Nos

Subject 600-111 Septic System Cleanup Verification 95\% UCL Calculations

ALCULATION SHEE

Date $\frac{08 / 03 / 08}{14055} \quad$ Calc. No. $0600 \mathrm{X}-\mathrm{CA}-\mathrm{V} 0070$

14655 Checked W. S. Thompsongy
Rev. No.

Date $\frac{1}{08 / 03 / 08}$

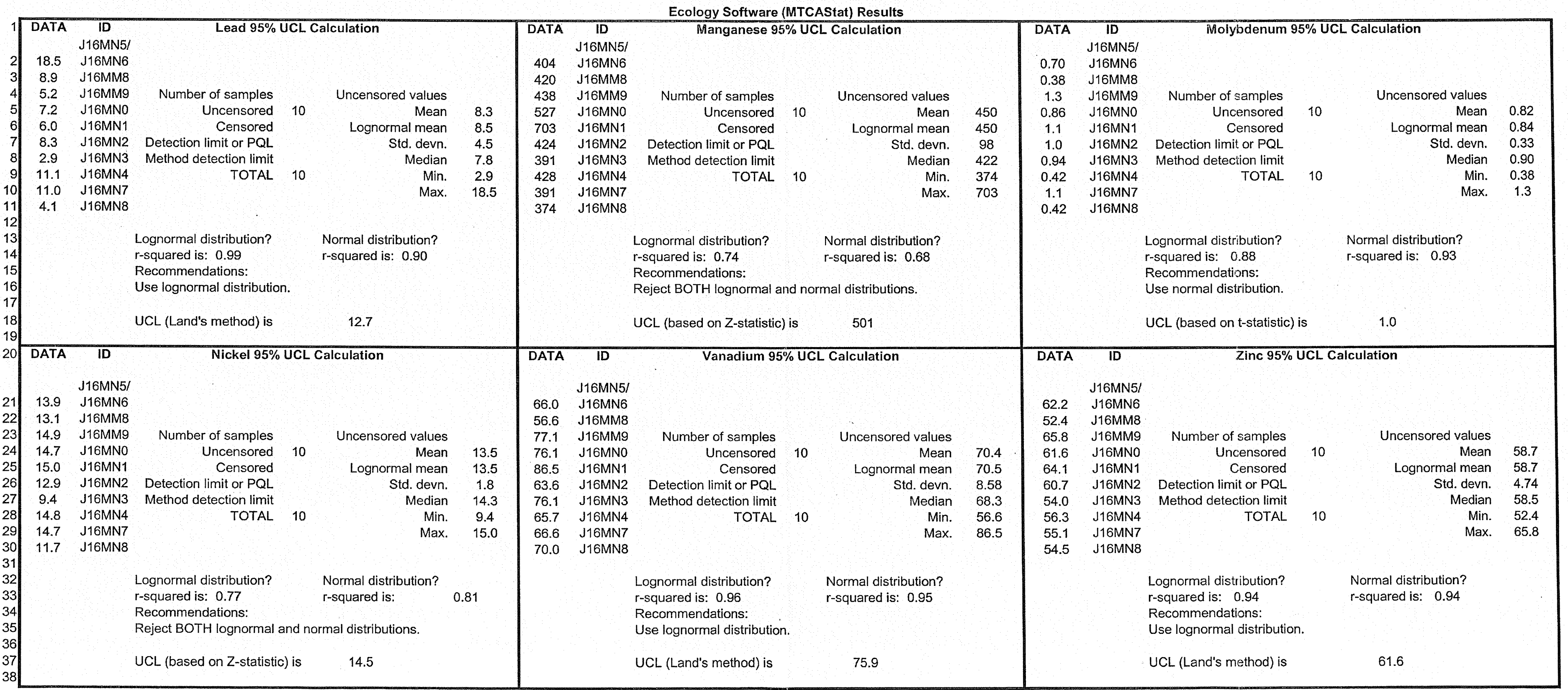


CALCULATION SHEET

Date $08 / 03 / 08$

Originator H.M. Sulte Hanford o

Subject 600 Area Field Remediatition

Ecology Software (MTCAStat) Results

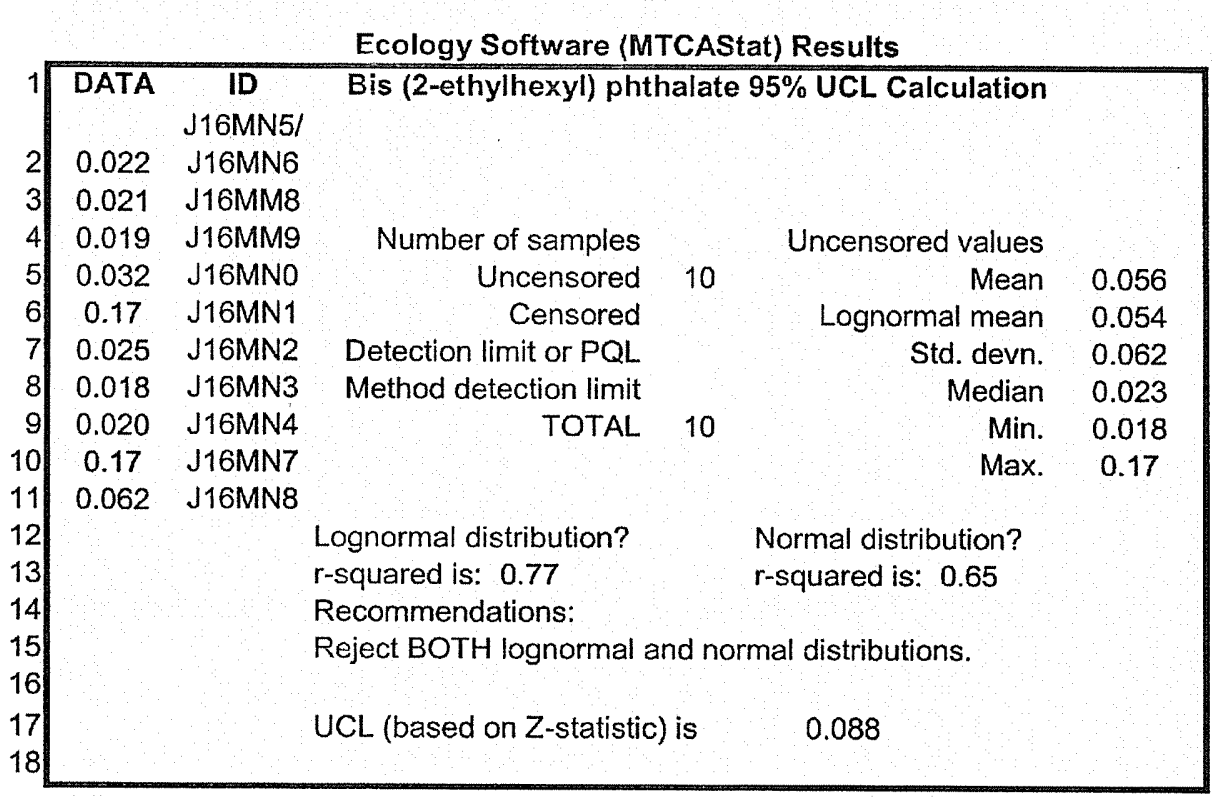

Calc. No. 0600X-CA-Vo070

Checked W. S. Thompson
Rev. No. $\frac{1}{08 / 03 / 08}$
Date

Sheet No. $\frac{08 / 03 / 08}{9 \text { of } 9}$ 
Attachment 1. 600-111 Septic System Verification Sampling Results.

\begin{tabular}{|c|c|c|c|c|c|c|c|c|c|c|c|c|c|c|c|c|c|c|c|c|}
\hline \multirow{3}{*}{$\begin{array}{c}\text { Sample } \\
\text { Location } \\
8\end{array}$} & \multirow{2}{*}{\begin{tabular}{|c|c|} 
HEIS \\
Number \\
\end{tabular}} & \multirow{2}{*}{$\begin{array}{c}\text { Sample } \\
\text { Date } \\
\end{array}$} & \multicolumn{3}{|c|}{ Aluminum } & \multicolumn{3}{|c|}{ Antimouy } & \multicolumn{2}{|c|}{$\begin{array}{c}\text { Arsenic } \\
\end{array}$} & \multicolumn{2}{|c|}{ Barium } & \multicolumn{2}{|c|}{ Beryllium } & \multicolumn{3}{|c|}{ Boron } & \multicolumn{3}{|c|}{ Cadmium } \\
\hline & & & $\mathrm{mg} / \mathrm{kg}$ & $Q$ & $\mathrm{PQL}$ & $\mathrm{mg} / \mathrm{kg}$ & Q & PQL & $\mathrm{mg} / \mathrm{kg}$ & \begin{tabular}{|l|l|}
$Q$ & PQL \\
\end{tabular} & $\mathrm{mg} / \mathrm{kg}$ & \begin{tabular}{|l|l|}
$\mathrm{Q}$ & $\mathrm{PQL}$ \\
\end{tabular} & $\mathrm{mg} / \mathrm{kg}$ & \begin{tabular}{|l|l|}
$\mathrm{Q}$ & $\mathrm{PQL}$ \\
\end{tabular} & $\mathrm{mg} / \mathrm{kg}$ & Q & PQL & $\mathrm{mg} / \mathrm{kg}$ & Q & $\mathrm{PQL}$ \\
\hline & J16MN5 & $4 / 21 / 2008$ & 10700 & & 9.1 & 0.79 & & 0.68 & 7.0 & \begin{tabular}{|l|l|} 
& 1.1 \\
\end{tabular} & 129 & 0.23 & 0.93 & 0.11 & 1.2 & & 1.1 & 0.11 & $\mathrm{U}$ & 0.11 \\
\hline & & & & & & & & & & & & & & & & & & & & \\
\hline $16 \mathrm{MN}$ & J16MN6 & $4 / 21 / 2008$ & 8410 & & 11.5 & 1.2 & & 0.87 & 5.0 & 1.4 & 107 & 0.29 & 0.82 & 0.14 & 1.4 & $\mathrm{U}$ & 1.4 & 0.14 & $\mathrm{U}$ & 0.14 \\
\hline 1 & J16MM & $1 / 2008$ & 11500 & & 10.1 & 1.0 & & 0.8 & 4.2 & 1.3 & 151 & 0.25 & 0.73 & 0.13 & 1.3 & $\mathrm{U}$ & 1.3 & 0.13 & $\mathrm{U}$ & 0.13 \\
\hline 2 & & $4 f$ & 10600 & & 10.1 & 0.76 & $\mathrm{U}$ & 0.76 & 1.7 & 1.3 & 168 & 0.24 & 1.1 & 0.13 & 1.3 & $\bar{U}$ & 1.3 & 0.13 & $U$ & 0.13 \\
\hline 3 & & & 10600 & & 9.3 & 0.70 & $\mathrm{U}$ & 0.70 & 4.1 & 1.2 & 170 & 0.23 & 0.92 & 0.1 & 1.2 & & 1.2 & 0.12 & & 0.12 \\
\hline 4 & $316 \mathrm{MN} 1$ & & 9280 & & 10 & 0.75 & $\overline{\mathrm{U}}$ & 0.7 & 3.3 & 1.2 & 137 & 0.2 & 1.1 & 0.12 & 1.2 & $\mathrm{U}$ & 1.2 & 0.12 & & 0.12 \\
\hline 5 & $\mathrm{~J} 16 \mathrm{~N}$ & & 9560 & & 7.9 & 0.59 & $\mathrm{U}$ & 0.59 & 3.6 & 0.98 & 156 & 0.20 & 0.84 & 0.1 & 0.98 & $\mathrm{U}$ & 1.0 & 0.10 & $\mathrm{U}$ & 0.10 \\
\hline 6 & $\mathrm{J16 \textrm {MN } 3}$ & & 6860 & & 10.2 & 0.76 & $\mathrm{U}$ & 0.76 & 2.8 & 1.3 & 91.4 & 0.25 & 0.88 & 0.13 & 1.3 & $\mathrm{U}$ & 1.3 & 0.13 & $\mathrm{U}$ & 0.13 \\
\hline 7 & J16MN4 & $4 / 21 / 2008$ & 10300 & & 11.1 & 0.99 & & 0.83 & 6.6 & 1.4 & 128 & 0.28 & 0.8 & 0.14 & 1.4 & $\mathrm{U}$ & 1.4 & 0.14 & $\mathrm{U}$ & 0.14 \\
\hline 9 & $\mathrm{~J} 16 \mathrm{MN} 7$ & & 8730 & & 10 & 0.75 & $\mathrm{U}$ & 0.75 & 6.1 & 1.3 & 126 & 0.25 & 0.75 & 0.13 & 1.3 & & 1.3 & 0.13 & & 0.13 \\
\hline 10 & J16 MN8 & $4 / 21 / 2008$ & 7840 & & 11.1 & 0.83 & $\mathrm{U}$ & 0.83 & 2.8 & 1.4 & 94.8 & 0.28 & 0.88 & 0.14 & 1.4 & $\mathrm{U}$ & 1.4 & 0.14 & $U$ & 0.14 \\
\hline equip blank & J16MM7 & $4 / 21 / 2008$ & 50.2 & & 3.4 & 0.26 & $\mathrm{U}$ & 0.26 & 0.43 & 0.43 & & 0.09 & 0.04 & 0.04 & 0.43 & $\mathrm{U}$ & 0.43 & 0.04 & $\bar{U}$ & 0 \\
\hline
\end{tabular}

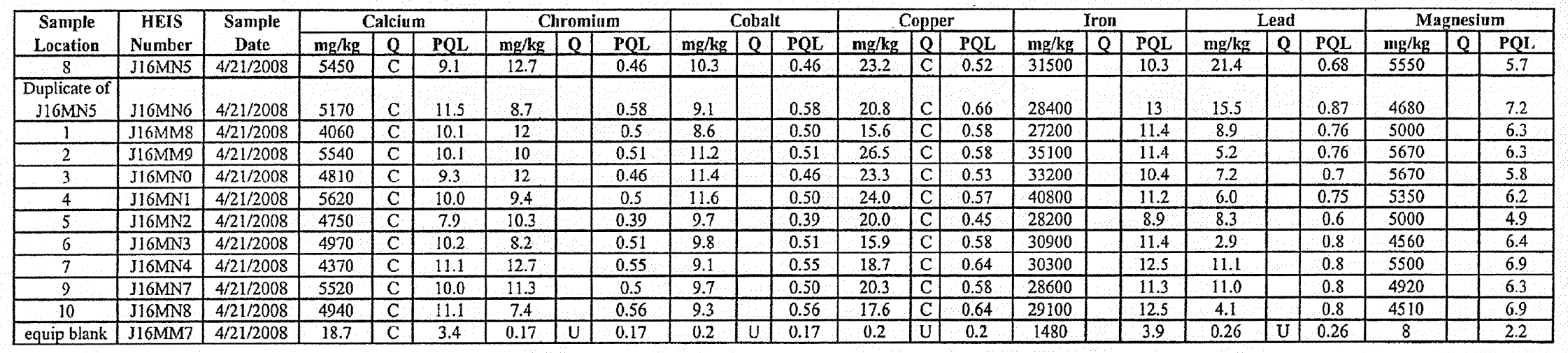

Attachment

Originator

Calc. No

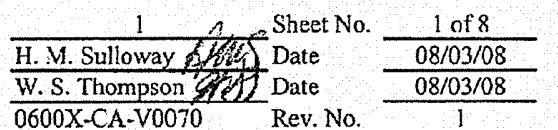


Attachment 1. 600-111 Septic System Verification Sampling Results.

\begin{tabular}{|c|c|c|c|c|c|c|c|c|c|c|c|c|c|c|c|c|c|c|c|c|c|c|c|}
\hline \multirow{2}{*}{$\begin{array}{c}\text { Sample } \\
\text { Location } \\
\end{array}$} & \multirow{2}{*}{$\begin{array}{c}\text { HEIS } \\
\text { Number }\end{array}$} & \multirow{2}{*}{$\begin{array}{c}\text { Sample } \\
\text { Date }\end{array}$} & \multicolumn{3}{|c|}{ Manganese } & \multicolumn{3}{|c|}{ Mercury } & \multicolumn{3}{|c|}{ Molybdenum } & \multicolumn{3}{|c|}{ Nickel } & \multicolumn{3}{|c|}{ Potassium } & \multicolumn{3}{|c|}{ Selenium } & \multicolumn{3}{|c|}{ Silicon } \\
\hline & & & $\mathrm{mg} / \mathrm{kg}$ & $Q$ & PQL & $\mathrm{mg} / \mathrm{kg}$ & $Q$ & PQL & $\mathrm{mg} / \mathrm{kg}$ & $Q$ & $\mathrm{PQL}$ & $\mathrm{mg} / \mathrm{kg}$ & $Q$ & PQL & $\mathrm{mg} / \mathrm{kg}$ & $Q$ & $\mathrm{PQL}$ & $\mathrm{mg} / \mathrm{kg}$ & $Q$ & PQL & $\mathrm{mg} / \mathrm{kg}$ & $Q$ & PQL \\
\hline 8 & J16MN5 & $4 / 21 / 2008$ & 441 & $\vec{C}$ & 0.09 & 0.03 & & 0.008 & 0.96 & & 0.68 & 16 & & 0.46 & 1760 & & 112 & 1.4 & $\mathrm{U}$ & 1.4 & 378 & & 9.1 \\
\hline $\begin{array}{l}\text { Duplicate of } \\
\text { J16MN5 }\end{array}$ & J16MN6 & $4 / 21 / 2008$ & 367 & C & 0.12 & 0.01 & $\mathrm{U}$ & 0.01 & 0.87 & U & 0.87 & 11.8 & & 0.58 & 1270 & & 142 & 1.7 & u & 1.7 & 513 & & 11.5 \\
\hline 1 & J16MM8 & $4 / 21 / 2008$ & 420 & C & 0.10 & 0.009 & $\mathrm{U}$ & 0.009 & 0.76 & $\mathrm{U}$ & 0.76 & 13.1 & & 0.50 & 1620 & & 124 & 1.5 & $\mathrm{U}$ & 1.5 & 498 & & 10.1 \\
\hline 2 & J16MM9 & $4 / 21 / 2008$ & 438 & $\mathrm{C}$ & 0.10 & 0.01 & $\mathrm{U}$ & 0.01 & 1.3 & & 0.76 & 14.9 & & 0.51 & 1080 & & 124 & 1.5 & $\mathrm{u}$ & 1.5 & 470 & & 10.1 \\
\hline 3 & J16MNO & $4 / 21 / 2008$ & 527 & $\mathrm{C}$ & 0.09 & 0.009 & U & 0.009 & 0.86 & & 0.70 & 14.7 & & 0.46 & 1270 & & 114 & 1.4 & $\mathrm{U}$ & 1.4 & 453 & & 9.3 \\
\hline 4 & JIGMN1 & $4 / 21 / 2008$ & 703 & $\mathrm{C}$ & 0.10 & 0.009 & $\bar{U}$ & 0.009 & 1.1 & & 0.75 & 15 & & 0.50 & 957 & & 123 & 1.5 & $\mathrm{U}$ & 1.5 & 399 & & 10.0 \\
\hline 5 & J16MN2 & $4 / 21 / 2008$ & 424 & $\mathrm{C}$ & 0.08 & 0.008 & $\mathrm{U}$ & 0.008 & 1.0 & & 0.59 & 12.9 & & 0.39 & 1250 & & 96.9 & 1.2 & $\mathrm{U}$ & 1.2 & 432 & & 7.9 \\
\hline 6 & J16MN3 & $4 / 21 / 2008$ & 391 & C. & 0.10 & 0.01 & $\mathrm{U}$ & 0.01 & 0.94 & & 0.76 & 9.4 & & 0.51 & 663 & & 125 & 1.5 & $\mathrm{U}$ & 1.5 & 316 & & 10.2 \\
\hline 7 & J16MN4 & $4 / 21 / 2008$ & 428 & C & 0.11 & 0.009 & $\mathrm{U}$ & 0.009 & 0.83 & U & 0.83 & 14.8 & & 0.55 & 1680 & & 137 & 1.7 & $\mathrm{U}$ & 1.7 & 494 & & 11.1 \\
\hline 9 & J16MN7 & $4 / 21 / 2008$ & 391 & $\mathrm{C}$ & 0.10 & 0.009 & $\mathrm{U}$ & 0.009 & 1.1 & & 0.75 & 14.7 & & 0.50 & 1390 & & 124 & 1.5 & $\mathrm{U}$ & 1.5 & 404 & & 10.0 \\
\hline 10 & J16MN8 & $4 / 21 / 2008$ & 374 & $\mathrm{C}$ & 0.11 & 0.02 & & 0.01 & 0.83 & $\mathrm{U}$ & 0.83 & 11.7 & & 0.56 & 1060 & & 137 & 1.7 & $\mathrm{U}$ & 1.7 & 441 & & 11.1 \\
\hline equip blank & J16MM7 & $4 / 21 / 2008$ & 11.5 & c & 0.03 & 0.009 & $\mathrm{U}$ & 0.009 & 0.26 & $\mathrm{U}$ & 0.26 & 0.2 & & 0.17 & 53.2 & & 42.5 & 0.52 & $\mathrm{U}$ & 0.52 & 41.8 & & 3.4 \\
\hline
\end{tabular}

\begin{tabular}{|c|c|c|c|c|c|c|c|c|c|c|c|c|c|c|}
\hline \multirow{2}{*}{$\begin{array}{c}\text { Sample } \\
\text { Location }\end{array}$} & \multirow{2}{*}{$\begin{array}{c}\text { HEIS } \\
\text { Number }\end{array}$} & \multirow{2}{*}{$\begin{array}{c}\text { Sample } \\
\text { Date }\end{array}$} & \multicolumn{3}{|c|}{ Silver } & \multicolumn{3}{|c|}{ Sodium } & \multicolumn{3}{|c|}{ Vanadium } & \multicolumn{3}{|c|}{ Zinc } \\
\hline & & & $\mathrm{mg} / \mathrm{kg}$ & $Q$ & $\mathrm{PQL}$ & $\mathrm{mg} / \mathrm{kg}$ & $Q$ & $\mathbf{P Q L}$ & $\mathrm{mg} / \mathrm{kg}$ & $Q$ & PQL & $\mathrm{mg} / \mathrm{kg}$ & $Q$ & $\mathrm{PQL}$ \\
\hline 8 & J16MN5 & $4 / 21 / 2008$ & 0.23 & $\overline{\mathrm{U}}$ & 0.23 & 200 & C & 4.6 & 69.6 & & 0.32 & 66.7 & & 1.4 \\
\hline $\begin{array}{l}\text { Duplicate of } \\
\text { JI6MN5 }\end{array}$ & J16MN6 & $4 / 21 / 2008$ & 0.29 & U & 0.29 & 176 & C & 5.8 & 62.4 & & 0.40 & 57.7 & & 1.7 \\
\hline 1 & J16MM8 & $4 / 21 / 2008$ & 0.25 & $\mathrm{U}$ & 0.25 & 176 & $\mathrm{C}$ & 5.0 & 56.6 & & 0.35 & 52.4 & & 1.5 \\
\hline 2 & J16MM9 & $4 / 21 / 2008$ & 0.25 & $U$ & 0.25 & 183 & C. & 5.1 & 77.1 & & 0.35 & 65.8 & & 1.5 \\
\hline 3 & J16MN0 & $4 / 21 / 2008$ & 0.23 & $\mathrm{U}$ & 0.23 & 180 & $\mathrm{C}$ & 4.6 & 76.1 & & 0.33 & 61.6 & & 1.4 \\
\hline 4 & J16MN1 & $4 / 21 / 2008$ & 0.25 & $\bar{U}$ & 0.25 & 187 & $\mathrm{C}$ & 5.0 & 86.5 & & 0.35 & 64.1 & & 1.5 \\
\hline 5 & $\mathrm{~J} 16 \mathrm{MN} 2$ & $4 / 21 / 2008$ & 0.20 & $\mathrm{U}$ & 0.20 & 130 & C & 3.9 & 63.6 & & 0.28 & 60.7 & & 1.2 \\
\hline 6 & $316 \mathrm{MN} 3$ & $4 / 21 / 2008$ & 0.25 & $\mathrm{U}$ & 0.25 & 133 & C & 5.1 & 76.1 & & 0.36 & 54.0 & & 1.5 \\
\hline 7 & $\mathrm{~J} 16 \mathrm{MN} 4$ & $4 / 21 / 2008$ & 0.28 & $\mathrm{U}$ & 0.28 & 175 & $\mathrm{C}$ & 5.5 & 65.7 & & 0.39 & 56.3 & & 1.7 \\
\hline 9 & J16MN7 & $4 / 21 / 2008$ & 0.25 & $\mathrm{U}$ & 0.25 & 179 & $\mathrm{C}$ & 5.0 & 66.6 & & 0.35 & 55.1 & & 1.5 \\
\hline 10 & JI6MN8 & $4 / 21 / 2008$ & 0.28 & $\mathrm{U}$ & 0.28 & 188 & C & 5.6 & 70.0 & & 0.39 & 54.5 & & 1.7 \\
\hline equip blank: & $\mathrm{J} 16 \mathrm{MM} 7$ & $4 / 21 / 2008$ & 0.1 & $\mathrm{U}$ & 0.09 & 16 & C & 1.7 & 0.12 & & 0.12 & 1.0 & & 0.5 \\
\hline
\end{tabular}


Attachment 1. 600-111 Septic System Verification Sampling Results.

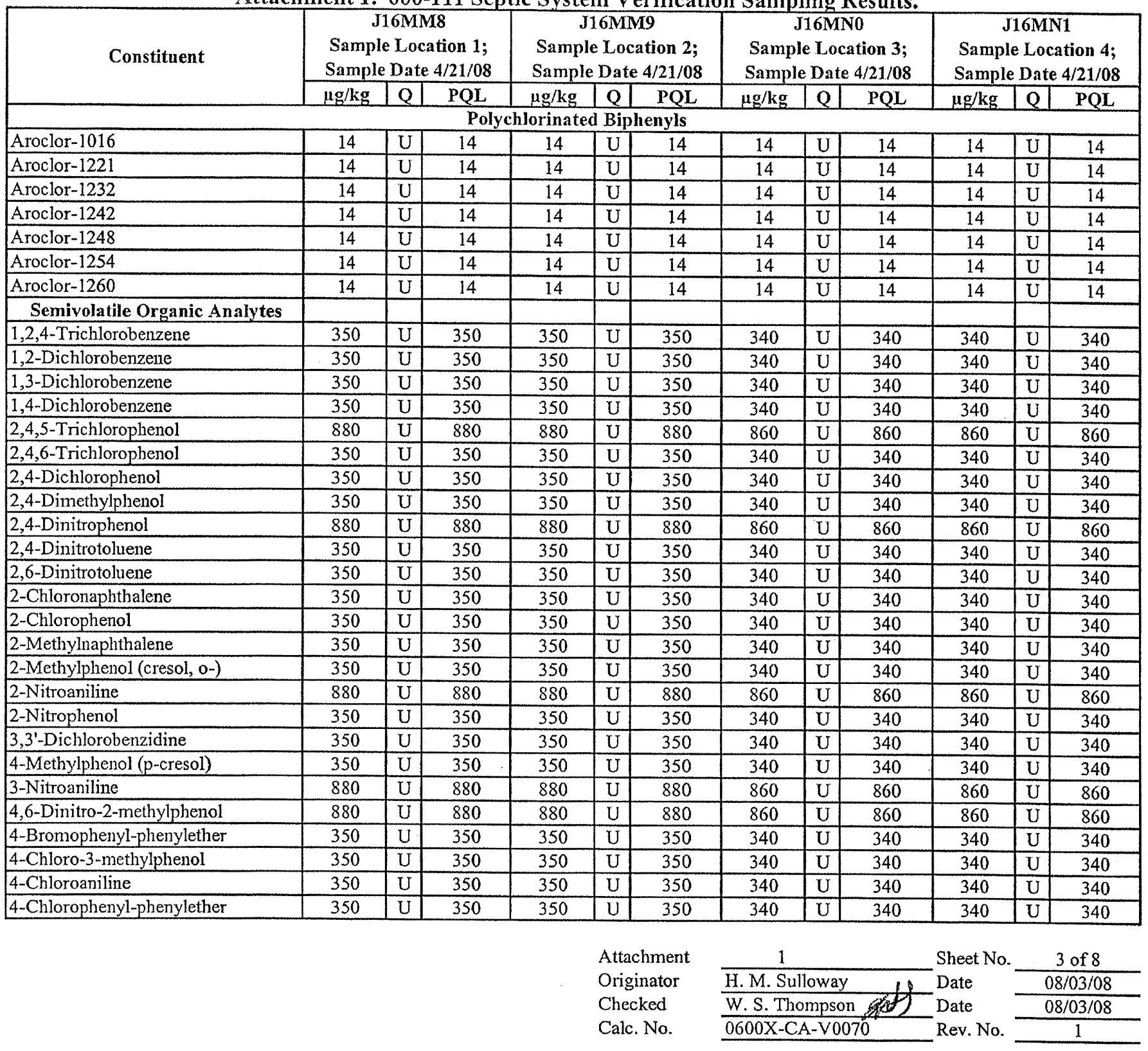


Attachment 1. 600-111 Septic System Verification Sampling Results.

\begin{tabular}{|c|c|c|c|c|c|c|c|c|c|c|c|c|}
\hline \multirow[t]{2}{*}{ Constituent } & \multicolumn{3}{|c|}{$\begin{array}{c}\text { J16MM8 } \\
\text { Sample Location 1; } \\
\text { Sample Date 4/21/08 }\end{array}$} & \multicolumn{3}{|c|}{$\begin{array}{c}\text { J16MM9 } \\
\text { Sample Location 2; } \\
\text { Sample Date 4/21/08 }\end{array}$} & \multicolumn{3}{|c|}{$\begin{array}{c}\text { J16MN0 } \\
\text { Sample Location 3; } \\
\text { Sample Date 4/21/08 }\end{array}$} & \multicolumn{3}{|c|}{$\begin{array}{c}\text { J16MN1 } \\
\text { Sample Location 4; } \\
\text { Sample Date 4/21/08 } \\
\end{array}$} \\
\hline & $\mu \mathrm{g} / \mathrm{kg}$ & Q & PQL & $\mu \mathrm{g} / \mathrm{kg}$ & Q] & PQL & $\mu \mathrm{g} / \mathrm{kg}$ & $Q$ & PQL & $\mu \mathrm{g} / \mathrm{kg}$ & Q & PQL \\
\hline \multicolumn{13}{|c|}{ Semivolatile Organic Analytes (continued) } \\
\hline 4-Nitroaniline & 880 & $\mathrm{U}$ & 880 & 880 & $\mathrm{U}$ & 880 & 860 & $\mathrm{U}$ & 860 & 860 & $\mathrm{U}$ & 860 \\
\hline 4-Nitrophenol & 880 & $\bar{U}$ & 880 & 880 & $\mathrm{U}$ & 880 & 860 & U & 860 & 860 & $\bar{U}$ & 860 \\
\hline Acenaphthene & 350 & $\mathrm{U}$ & 350 & 350 & 0 & 350 & 340 & $\mathrm{U}$ & 340 & 340 & U & 340 \\
\hline Acenaphthylene & 350 & $U$ & 350 & 350 & $\mathrm{U}$ & 350 & 340 & $\mathrm{U}$ & 340 & 340 & U & 340 \\
\hline Anthracene & 350 & $\mathrm{U}$ & 350 & 350 & $\mathrm{U}$ & 350 & 340 & $\mathrm{U}$ & 340 & 340 & $\mathrm{U}$ & 340 \\
\hline Benzo(a)anthracene & 350 & $\mathrm{U}$ & 350 & 350 & $\mathrm{U}$ & 350 & 340 & $\mathrm{U}$ & 340 & 340 & $\mathrm{U}$ & 340 \\
\hline Benzo(a)pyrene & 350 & $\mathrm{U}$ & 350 & 350 & $\mathrm{U}$ & 350 & 340 & $U$ & 340 & 340 & $\mathrm{U}$ & 340 \\
\hline Benzo(b)fluoranthene & 350 & $\mathrm{U}$ & 350 & 350 & $\mathrm{U}$ & 350 & 340 & $\mathrm{U}$ & 340 & 340 & $\mathrm{U}$ & 340 \\
\hline Benzo $(\mathrm{g}, \mathrm{h}, \mathrm{i})$ perylene & 350 & $\mathrm{U}$ & 350 & 350 & $\mathrm{U}$ & 350 & 340 & $\mathrm{U}$ & 340 & 340 & $\mathrm{U}$ & 340 \\
\hline Benzo(k)fluoranthene & 350 & $\mathrm{U}$ & 350 & 350 & $\mathrm{U}$ & 350 & 340 & U & 340 & 340 & $\mathrm{U}$ & 340 \\
\hline Bis(2-chloro-1-methylethyl)ether & 350 & $\mathrm{U}$ & 350 & 350 & $\mathrm{U}$ & 350 & 340 & $\mathrm{U}$ & 340 & 340 & $\mathrm{U}$ & 340 \\
\hline Bis(2-chloroethoxy)methane & 350 & $\mathrm{U}$ & 350 & 350 & $\mathrm{U}$ & 350 & 340 & $\mathrm{U}$ & 340 & 340 & $\mathrm{U}$ & 340 \\
\hline Bis(2-chloroethyl) ether & 350 & $\mathrm{U}$ & 350 & 350 & $\mathrm{U}$ & 350 & 340 & $\mathrm{U}$ & 340 & 340 & $\mathrm{U}$ & 340 \\
\hline Bis(2-ethylhexyl) phthalate & 21 & $\mathrm{~J}$ & 350 & 19 & $\mathrm{~J}$ & 350 & 32 & $\mathrm{~J}$ & 340 & 340 & $\mathrm{U}$ & 340 \\
\hline Butylbenzylphthalate & 350 & $\mathrm{U}$ & 350 & 350 & $\mathrm{U}$ & 350 & 340 & $\mathrm{U}$ & 340 & 340 & $\mathrm{U}$ & 340 \\
\hline Carbazole & 350 & $\mathrm{U}$ & 350 & 350 & $\mathrm{U}$ & 350 & 340 & $\mathrm{U}$ & 340 & 340 & $\mathrm{U}$ & 340 \\
\hline Chrysene & 350 & $\mathrm{U}$ & 350 & 350 & $\mathrm{U}$ & 350 & 340 & $\mathrm{U}$ & 340 & 340 & $\mathrm{U}$ & 340 \\
\hline Dibenz $(a, h)$ anthracene & 350 & $\mathrm{U}$ & 350 & 350 & $\mathrm{U}$ & 350 & 340 & $\mathrm{U}$ & 340 & 340 & $\mathrm{U}$ & 340 \\
\hline Dibenzofuran & 350 & $\mathrm{U}$ & 350 & 350 & U & 350 & 340 & $\mathrm{U}$ & 340 & 340 & $\mathrm{U}$ & 340 \\
\hline Diethylphthalate & 350 & $\mathrm{U}$ & 350 & 350 & $\mathrm{U}$ & 350 & 340 & $\mathrm{U}$ & 340 & 340 & $\mathrm{U}$ & 340 \\
\hline Dimethylphthalate & 350 & $\mathrm{U}$ & 350 & 350 & $\mathrm{U}$ & 350 & 340 & $\mathrm{U}$ & 340 & 340 & $\mathrm{U}$ & 340 \\
\hline Di-n-butylphthalate & 350 & $\mathrm{U}$ & 350 & 350 & $\mathrm{U}$ & 350 & 340 & $\mathrm{U}$ & 340 & 340 & $\mathrm{U}$ & 340 \\
\hline Di-n-octylphthalate & 350 & $\mathrm{U}$ & 350 & 350 & $\mathrm{U}$ & 350 & 340 & $\mathrm{U}$ & 340 & 340 & $\mathrm{U}$ & 340 \\
\hline Fluoranthene & 350 & $U$ & 350 & 350 & $\mathrm{U}$ & 350 & 340 & U & 340 & 340 & $\mathrm{U}$ & 340 \\
\hline Fluorene & 350 & $\mathrm{U}$ & 350 & 350 & $\mathrm{U}$ & 350 & 340 & U & 340 & 340 & $\mathrm{U}$ & 340 \\
\hline Hexachlorobenzene & 350 & $\mathrm{U}$ & 350 & 350 & $\mathrm{U}$ & 350 & 340 & $\mathrm{U}$ & 340 & 340 & $\mathrm{U}$ & 340 \\
\hline Hexachlorobutadiene & 350 & $\mathrm{U}$ & 350 & 350 & $\mathrm{U}$ & 350 & 340 & $\mathrm{U}$ & 340 & 340 & $\mathrm{U}$ & 340 \\
\hline Hexachlorocyclopentadiene & 350 & $\mathrm{U}$ & 350 & 350 & $\mathrm{U}$ & 350 & 340 & $\mathrm{U}$ & 340 & 340 & $\mathrm{U}$ & 340 \\
\hline Hexachloroethane & 350 & $\mathrm{U}$ & 350 & 350 & $\mathrm{U}$ & 350 & 340 & $\mathrm{U}$ & 340 & 340 & $\mathrm{U}$ & 340 \\
\hline Indeno(1,2,3-cd)pyrene & 350 & $\mathrm{U}$ & 350 & 350 & $\mathrm{U}$ & 350 & 340 & $\mathrm{U}$ & 340 & 340 & $\mathrm{U}$ & 340 \\
\hline Isophorone & 350 & $\mathrm{U}$ & 350 & 350 & $\mathrm{U}$ & 350 & 340 & $\mathrm{U}$ & 340 & 20 & $\mathrm{~J}$ & 340 \\
\hline Naphthalene & 350 & $\mathrm{U}$ & 350 & 350 & $\mathrm{U}$ & 350 & 340 & $\mathrm{U}$ & 340 & 340 & $\mathrm{U}$ & 340 \\
\hline Nitrobenzene & 350 & $\mathrm{U}$ & 350 & 350 & $\mathrm{U}$ & 350 & 340 & $\mathrm{U}$ & 340 & 340 & $\mathrm{U}$ & 340 \\
\hline N-Nitroso-di-n-dipropylamine & 350 & $\mathrm{U}$ & 350 & 350 & $\mathrm{U}$ & 350 & 340 & $\mathrm{U}$ & 340 & 340 & $\mathrm{U}$ & 340 \\
\hline N-Nitrosodiphenylamine & 350 & $\mathrm{U}$ & 350 & 350 & $\mathrm{U}$ & 350 & 340 & $\mathrm{U}$ & 340 & 340 & $\mathrm{U}$ & 340 \\
\hline Pentachlorophenol & 880 & $\mathrm{U}$ & 880 & 880 & $\mathrm{U}$ & 880 & 860 & $\mathrm{U}$ & 860 & 860 & $\mathrm{U}$ & 860 \\
\hline Phenanthrene & 350 & $\mathrm{U}$ & 350 & 350 & $\mathrm{U}$ & 350 & 340 & $\mathrm{U}$ & 340 & 340 & $\mathrm{U}$ & 340 \\
\hline \begin{tabular}{|l} 
Phenol \\
\end{tabular} & 350 & $\mathrm{U}$ & 350 & 350 & $\mathrm{U}$ & 350 & 340 & $\mathrm{U}$ & 340 & 340 & $\mathrm{U}$ & 340 \\
\hline Pyrene & 350 & $\mathrm{U}$ & 350 & 350 & $\mathrm{U}$ & 350 & 340 & $\mathrm{U}$ & 340 & 340 & $\mathrm{U}$ & 340 \\
\hline & & & & & Atta & ment & 1 & & & Sheet No. & & 4 of 8 \\
\hline & & & & & Orig & ator & H.M. Sr & oway & & Date & & $8 / 03 / 08$ \\
\hline & & & & & Che & & W.S.Th & mpso & ero & Date & & $8 / 03 / 08$ \\
\hline & & & & & Calc & No. & $0600 \mathrm{X}-\mathrm{C}$ & $-\mathrm{VOC}$ & & Rev. No. & & 1 \\
\hline
\end{tabular}


Attachment 1. 600-111 Septic System Verification Sampling Results.

\begin{tabular}{|c|c|c|c|c|c|c|c|c|c|c|c|c|}
\hline \multirow[t]{2}{*}{ Constituent } & \multicolumn{3}{|c|}{$\begin{array}{c}\text { J16MN2 } \\
\text { Sample Location 5; } \\
\text { Sample Date } 4 / 21 / 08\end{array}$} & \multicolumn{3}{|c|}{$\begin{array}{c}\text { J16MN3 } \\
\text { Sample Location 6; } \\
\text { Sample Date 4/21/08 }\end{array}$} & \multicolumn{3}{|c|}{$\begin{array}{c}\text { J16MN4 } \\
\text { Sample Location 7; } \\
\text { Sample Date 4/21/08 } \\
\end{array}$} & \multicolumn{3}{|c|}{$\begin{array}{c}\text { J16MN5 } \\
\text { Sample Location 8; } \\
\text { Sample Date 4/21/08 }\end{array}$} \\
\hline & $\mu \mathrm{g} / \mathrm{kg}$ & $\mathbf{Q}$ & PQL & $\mu \mathrm{g} / \mathrm{kg}$ & Q & $\mathrm{PQL}$ & $\mu \mathrm{g} / \mathrm{kg}$ & $\mathrm{Q}$ & PQL & $\mu \mathrm{g} / \mathrm{kg}$ & $Q$ & $\mathrm{PQL}$ \\
\hline \multicolumn{13}{|c|}{ Polychlorinated Biphenyls } \\
\hline Aroclor-1016 & 14 & $\mathrm{U}$ & 14 & 14 & $\mathrm{U}$ & 14 & 14 & $\mathrm{U}$ & 14 & 14 & $\mathrm{U}$ & 14 \\
\hline Aroclor-1221 & 14 & $\mathrm{U}$ & 14 & 14 & $\mathrm{U}$ & 14 & 14 & U & 14 & 14 & $\mathrm{U}$ & 14 \\
\hline Aroclor-1232 & 14 & $\mathrm{U}$ & 14 & 14 & $\mathrm{U}$ & 14 & 14 & $\mathrm{U}$ & 14 & 14 & $\mathrm{U}$ & 14 \\
\hline Aroclor- 1242 & 14 & $\mathrm{U}$ & 14 & 14 & $\mathrm{U}$ & 14 & 14 & $\mathrm{U}$ & 14 & 14 & $\mathrm{U}$ & 14 \\
\hline Aroclor-1248 & 14 & $\mathrm{U}$ & 14 & 14 & $\mathrm{U}$ & 14 & 14 & $\bar{U}$ & 14 & 14 & $\mathrm{U}$ & 14 \\
\hline Aroclor-1254 & 14 & $\mathrm{U}$ & 14 & 14 & $\mathrm{U}$ & 14 & 14 & $\mathrm{U}$ & 14 & 14 & $\mathrm{U}$ & 14 \\
\hline Aroclor -1260 & 14 & $\mathrm{U}$ & 14 & 14 & $\mathrm{U}$ & 14 & 14 & $\mathrm{U}$ & 14 & 14 & $\mathrm{U}$ & 14 \\
\hline \multicolumn{13}{|c|}{ Semivolatile Organic Analytes } \\
\hline 1,2,4-Trichlorobenzene & 340 & $\mathrm{U}$ & 340 & 350 & $\mathrm{U}$ & 350 & 360 & $\mathrm{U}$ & 360 & 350 & $\mathrm{U}$ & 350 \\
\hline 1,2-Dichlorobenzene & 340 & $\mathrm{U}$ & 340 & 350 & $\mathrm{U}$ & 350 & 360 & $\mathrm{U}$ & 360 & 350 & U & 350 \\
\hline 1,3-Dichlorobenzene & 340 & $\mathrm{U}$ & 340 & 350 & $\mathrm{U}$ & 350 & 360 & $\mathrm{U}$ & 360 & 350 & $\mathrm{U}$ & 350 \\
\hline 1,4-Dichlorobenzene & 340 & $\mathrm{U}$ & 340 & 350 & $\mathrm{U}$ & 350 & 360 & $\mathrm{U}$ & 360 & 350 & $\mathrm{U}$ & 350 \\
\hline 2,4,5-Trichlorophenol & 850 & $\mathrm{U}$ & 850 & 870 & $\mathrm{U}$ & 870 & 900 & $\mathrm{U}$ & 900 & 870 & $\mathrm{U}$ & 870 \\
\hline 2,4,6-Trichlorophenol & 340 & $\mathrm{U}$ & 340 & 350 & $\mathrm{U}$ & 350 & 360 & $\mathrm{U}$ & 360 & 350 & $U$ & 350 \\
\hline 2,4-Dichlorophenol & 340 & $\mathrm{U}$ & 340 & 350 & $\mathrm{U}$ & 350 & 360 & $\mathrm{U}$ & 360 & 350 & $\mathrm{U}$ & 350 \\
\hline 2,4-Dimethylphenol & 340 & $\mathrm{U}$ & 340 & 350 & $\mathrm{U}$ & 350 & 360 & $\mathrm{U}$ & 360 & 350 & $\mathrm{U}$ & 350 \\
\hline 2,4-Dinitrophenol & 850 & $\mathrm{U}$ & 850 & 870 & $U$ & 870 & 900 & $\mathrm{U}$ & 900 & 870 & $\mathrm{U}$ & 870 \\
\hline 2,4-Dinitrotoluene & 340 & $\mathrm{U}$ & 340 & 350 & $\mathrm{U}$ & 350 & 360 & $\mathrm{U}$ & 360 & 350 & $\mathrm{U}$ & 350 \\
\hline 2,6-Dinitrotoluene & 340 & $\mathrm{U}$ & 340 & 350 & $\mathrm{U}$ & 350 & 360 & $\mathrm{U}$ & 360 & 350 & $\mathrm{U}$ & 350 \\
\hline 2-Chloronaphthalene & 340 & $\mathrm{U}$ & 340 & 350 & $\mathrm{U}$ & 350 & 360 & $\mathrm{U}$ & 360 & 350 & $\mathrm{U}$ & 350 \\
\hline 2-Chlorophenol & 340 & $\mathrm{U}$ & 340 & 350 & $\mathrm{U}$ & 350 & 360 & $\mathrm{U}$ & 360 & 350 & $\mathrm{U}$ & 350 \\
\hline 2-Methylnaphthalene & 340 & $\mathrm{U}$ & 340 & 350 & $\mathrm{U}$ & 350 & 360 & $\mathrm{U}$ & 360 & 350 & $\mathrm{U}$ & 350 \\
\hline 2-Methylphenol (cresol, o-) & 340 & $\mathrm{U}$ & 340 & 350 & $\mathrm{U}$ & 350 & 360 & $\mathrm{U}$ & 360 & 350 & $\mathrm{U}$ & 350 \\
\hline 2-Nitroaniline & 850 & $\mathrm{U}$ & 850 & 870 & $\mathrm{U}$ & 870 & 900 & $\mathrm{U}$ & 900 & 870 & $\mathrm{U}$ & 870 \\
\hline 2-Nitrophenol & 340 & $\mathrm{U}$ & 340 & 350 & $\mathrm{U}$ & 350 & 360 & $\mathrm{U}$ & 360 & 350 & $\mathrm{U}$ & 350 \\
\hline 3,3'-Dichlorobenzidine & 340 & $\mathrm{U}$ & 340 & 350 & $\mathrm{U}$ & 350 & 360 & $\mathrm{U}$ & 360 & 350 & $\mathrm{U}$ & 350 \\
\hline 4-Methylphenol (p-cresol) & 340 & $\mathrm{U}$ & 340 & 350 & $\mathrm{U}$ & 350 & 360 & $U$ & 360 & 350 & $\mathrm{U}$ & 350 \\
\hline 3-Nitroaniline & 850 & $\mathrm{U}$ & 850 & 870 & $\mathrm{U}$ & 870 & 900 & $\mathrm{U}$ & 900 & 870 & $\mathrm{U}$ & 870 \\
\hline 4,6-Dinitro-2-methylphenol & 850 & $\mathrm{U}$ & 850 & 870 & $\mathrm{U}$ & 870 & 900 & $\mathrm{U}$ & 900 & 870 & $\mathrm{U}$ & 870 \\
\hline 4-Bromophenyl-phenylether & 340 & $\mathrm{U}$ & 340 & 350 & $\mathrm{U}$ & 350 & 360 & U & 360 & 350 & $\mathrm{U}$ & 350 \\
\hline 4-Chloro-3-methylphenol & 340 & $\mathrm{U}$ & 340 & 350 & $\mathrm{U}$ & 350 & 360 & $\mathrm{U}$ & 360 & 350 & $\mathrm{U}$ & 350 \\
\hline 4-Chloroaniline & 340 & $\mathrm{U}$ & 340 & 350 & $\mathrm{U}$ & 350 & 360 & $\mathrm{U}$ & 360 & 350 & $\mathrm{U}$ & 350 \\
\hline 4-Chlorophenyl-phenylether & 340 & $\mathrm{U}$ & 340 & 350 & $\mathrm{U}$ & 350 & 360 & $\mathrm{U}$ & 360 & 350 & $\mathrm{U}$ & 350 \\
\hline & & & & & Atte & ment & 1 & & & Sheet No. & & 5 of 8 \\
\hline & & & & & Ori & ator & H.M. Su & oway & & Date & & $88 / 03 / 08$ \\
\hline & & & & & Che & & W.S.Th & 11050 & 240 & Date & & $88 / 03 / 08$ \\
\hline & & & & & Cal & & $0600 \mathrm{X}-\mathrm{C}$ & $-\mathrm{VOC}$ & & Rev. No. & & 1 \\
\hline
\end{tabular}


Attachment 1. 600-111 Septic System Verification Sampling Results.

\begin{tabular}{|c|c|c|c|c|c|c|c|c|c|c|c|c|}
\hline \multirow[t]{2}{*}{ Constituent } & \multicolumn{3}{|c|}{$\begin{array}{c}\text { J16MN2 } \\
\text { Sample Location 5; } \\
\text { Sample Date 4/21/08 }\end{array}$} & \multicolumn{3}{|c|}{$\begin{array}{c}\text { J16MN3 } \\
\text { Sample Location 6; } \\
\text { Sample Date 4/21/08 }\end{array}$} & \multicolumn{3}{|c|}{$\begin{array}{c}\text { J16MN4 } \\
\text { Sample Location 7; } \\
\text { Sample Date 4/21/08 }\end{array}$} & \multicolumn{3}{|c|}{$\begin{array}{c}\text { J16MN5 } \\
\text { Sample Location 8; } \\
\text { Sample Date 4/21/08 } \\
\end{array}$} \\
\hline & $\mu \mathrm{g} / \mathrm{kg}$ & $\mathbf{Q}$ & PQL & $\mu \mathrm{g} / \mathrm{kg}$ & $Q$ & PQL & $\mu \mathrm{g} / \mathrm{kg}$ & Q & PQL & $\mu \mathrm{g} / \mathrm{kg}$ & $Q$ & PQL \\
\hline \multicolumn{13}{|c|}{ Semivolatile Organic Analytes (continued) } \\
\hline 4-Nitroaniline & 850 & $\mathrm{U}$ & 850 & 870 & $\mathrm{U}$ & 870 & 900 & $\mathrm{U}$ & 900 & 870 & $\mathrm{U}$ & 870 \\
\hline 4-Nitrophenol & 850 & $\mathrm{U}$ & 850 & 870 & $\mathrm{U}$ & 870 & 900 & $\mathrm{U}$ & 900 & 870 & $\mathrm{U}$ & 870 \\
\hline Acenaphthene & 340 & $\mathrm{U}$ & 340 & 350 & $\mathrm{U}$ & 350 & 360 & $\mathrm{U}$ & 360 & 350 & $\mathrm{U}$ & 350 \\
\hline Acenaphthylene & 340 & $\mathrm{U}$ & 340 & 350 & $\mathrm{U}$ & 350 & 360 & U & 360 & 350 & $\mathrm{U}$ & 350 \\
\hline Anthracene & 340 & $\mathrm{U}$ & 340 & 350 & $\mathrm{U}$ & 350 & 360 & $\mathrm{U}$ & 360 & 350 & $\mathrm{U}$ & 350 \\
\hline Benzo(a)anthracene & 340 & $\mathrm{U}$ & 340 & 350 & U & 350 & 360 & $\mathrm{U}$ & 360 & 350 & $\mathrm{U}$ & 350 \\
\hline Benzo(a)pyrene & 340 & $\mathrm{U}$ & 340 & 350 & $\mathrm{U}$ & 350 & 360 & $\mathrm{U}$ & 360 & 350 & $\mathrm{U}$ & 350 \\
\hline Benzo(b)fluoranthene & 340 & $\mathrm{U}$ & 340 & 350 & $\mathrm{U}$ & 350 & 360 & $\mathrm{U}$ & 360 & 350 & $\mathrm{U}$ & 350 \\
\hline Benzo(g,h,i)perylene & 340 & $\mathrm{U}$ & 340 & 350 & $\mathrm{U}$ & 350 & 360 & $\mathrm{U}$ & 360 & 350 & $\mathrm{U}$ & 350 \\
\hline $\mathrm{Bcnzo}(\mathrm{k})$ fluoranthene & 340 & $\mathrm{U}$ & 340 & 350 & $\mathrm{U}$ & 350 & 360 & $\mathrm{U}$ & 360 & 350 & $U$ & 350 \\
\hline Bis(2-chloro-1-nethylethyl)ether & 340 & $\mathrm{U}$ & 340 & 350 & $\mathrm{U}$ & 350 & 360 & $\mathrm{U}$ & 360 & 350 & $\mathrm{U}$ & 350 \\
\hline Bis(2-chloroethoxy)methane & 340 & U & 340 & 350 & $\mathrm{U}$ & 350 & 360 & $\mathrm{U}$ & 360 & 350 & $\mathrm{U}$ & 350 \\
\hline Bis(2-chloroethyl) ether & 340 & $\mathrm{U}$ & 340 & 350 & $\mathrm{U}$ & 350 & 360 & $\mathrm{U}$ & 360 & 350 & $\mathrm{U}$ & 350 \\
\hline Bis(2-ethylhexyl) phthalate & 25 & $\mathrm{~J}$ & 340 & 18 & $\mathrm{~J}$ & 350 & 20 & $\mathrm{~J}$ & 360 & 26 & $\mathrm{~J}$ & 350 \\
\hline Butylbenzylphthalate & 340 & $\mathrm{U}$ & 340 & 350 & $\mathrm{U}$ & 350 & 360 & $U$ & 360 & 350 & $\mathrm{U}$ & 350 \\
\hline Carbazole & 340 & $\mathrm{U}$ & 340 & 350 & $\mathrm{U}$ & 350 & 360 & $\mathrm{U}$ & 360 & 350 & $\mathrm{U}$ & 350 \\
\hline Chrysene & 340 & $\mathrm{U}$ & 340 & 350 & $U$ & 350 & 360 & $\mathrm{U}$ & 360 & 350 & $\mathrm{U}$ & 350 \\
\hline Dibenz $(\mathrm{a}, \mathrm{h})$ anthracene & 340 & $\mathrm{U}$ & 340 & 350 & $\mathrm{U}$ & 350 & 360 & $\mathrm{U}$ & 360 & 350 & $\mathrm{U}$ & 350 \\
\hline Dibenzofuran & 340 & $\mathrm{U}$ & 340 & 350 & $\mathrm{U}$ & 350 & 360 & $\mathrm{U}$ & 360 & 350 & $\mathrm{U}$ & 350 \\
\hline Diethylphthalate & 340 & $\mathrm{U}$ & 340 & 350 & $\mathrm{U}$ & 350 & 360 & $\mathrm{U}$ & 360 & 350 & $\mathrm{U}$ & 350 \\
\hline Dimethylphthalate & 340 & $\mathrm{U}$ & 340 & 350 & $\mathrm{U}$ & 350 & 360 & $\mathrm{U}$ & 360 & 350 & $\mathrm{U}$ & 350 \\
\hline Di-n-butylphthalate & 340 & $\mathrm{U}$ & 340 & 350 & $\mathrm{U}$ & 350 & 360 & $\mathrm{U}$ & 360 & 350 & $\mathrm{U}$ & 350 \\
\hline Di-n-octylphthalate & 340 & $\mathrm{U}$ & 340 & 350 & $\mathrm{U}$ & 350 & 360 & $\mathrm{U}$ & 360 & 350 & $\mathrm{U}$ & 350 \\
\hline Fluoranthene & 340 & $\mathrm{U}$ & 340 & 350 & $\mathrm{U}$ & 350 & 360 & U & 360 & 350 . & $\mathrm{U}$ & 350 \\
\hline Fluorene & 340 & $\mathrm{U}$ & 340 & 350 & $\mathrm{U}$ & 350 & 360 & $\mathrm{U}$ & 360 & 350 & $\mathrm{U}$ & 350 \\
\hline Hexachlorobenzene & 340 & $\mathrm{U}$ & 340 & 350 & $\mathrm{U}$ & 350 & 360 & $\mathrm{U}$ & 360 & 350 & $\mathrm{U}$ & 350 \\
\hline Hexachlorobutadiene & 340 & $\mathrm{U}$ & 340 & 350 & $\mathrm{U}$ & 350 & 360 & $\bar{U}$ & 360 & 350 & $\mathrm{U}$ & 350 \\
\hline Hexachlorocyclopentadiene & 340 & $\mathrm{U}$ & 340 & 350 & $\mathrm{U}$ & 350 & 360 & $\mathrm{U}$ & 360 & 350 & $\mathrm{U}$ & 350 \\
\hline Hexachloroethane & 340 & $\mathrm{U}$ & 340 & 350 & $\bar{U}$ & 350 & 360 & $\mathrm{U}$ & 360 & 350 & $\mathrm{U}$ & 350 \\
\hline Indeno( $1,2,3$-cd)pyrene & 340 & $\mathrm{U}$ & 340 & 350 & $\mathrm{U}$ & 350 & 360 & $\mathrm{U}$ & 360 & 350 & $\mathrm{U}$ & 350 \\
\hline Isophorone & 340 & $\mathrm{U}$ & 340 & 350 & $\mathrm{U}$ & 350 & 360 & $\mathrm{U}$ & 360 & 350 & $\mathrm{U}$ & 350 \\
\hline Naphthalene & 340 & $\mathrm{U}$ & 340 & 350 & $\mathrm{U}$ & 350 & 360 & $\mathrm{U}$ & 360 & 350 & $\mathrm{U}$ & 350 \\
\hline Nitrobenzene & 340 & $\mathrm{U}$ & 340 & 350 & $\mathrm{U}$ & 350 & 360 & $\mathrm{U}$ & 360 & 350 & $\mathrm{U}$ & 350 \\
\hline N-Nitroso-di-n-dipropylamine & 340 & $\mathrm{U}$ & 340 & 350 & $\mathrm{U}$ & 350 & 360 & $\mathrm{U}$ & 360 & 350 & $\mathrm{U}$ & 350 \\
\hline N-Nitrosodiphenylamine & 340 & $\mathrm{U}$ & 340 & 350 & $\mathrm{U}$ & 350 & 360 & $\mathrm{U}$ & 360 & 350 & $\mathrm{U}$ & 350 \\
\hline Pentachlorophenol & 850 & $\mathrm{U}$ & 850 & 870 & $\mathrm{U}$ & 870 & 900 & $\mathrm{U}$ & 900 & 870 & $\mathrm{U}$ & 870 \\
\hline Phenanthrene & 340 & $\mathbf{U}$ & 340 & 350 & $\mathrm{U}$ & 350 & 360 & $\mathrm{U}$ & 360 & 350 & $\mathrm{U}$ & 350 \\
\hline Phenol & 340 & $\mathrm{U}$ & 340 & 350 & $\mathrm{U}$ & 350 & 360 & $\mathrm{U}$ & 360 & 350 & $\mathrm{U}$ & 350 \\
\hline Pyrene & 340 & $\mathrm{U}$ & 340 & 350 & $\mathrm{U}$ & 350 & 360 & $\mathrm{U}$ & 360 & 350 & $\mathrm{U}$ & 350 \\
\hline & & & & & Atta & ment & 1 & & & Sheet No. & & 6 of 8 \\
\hline & & & & & Ori & ator & $\mathrm{H} . \mathrm{M} . \mathrm{Sl}$ & oway & & Date & & $08 / 03 / 08$ \\
\hline & & & & & Che & & W.S.Th & mpso & & Date & & $08 / 03 / 08$ \\
\hline & & & & & Cal & No. & $0600 \mathrm{X}-\mathrm{C}$ & $\mathrm{-VO}$ & & Rev. No. & & 1 \\
\hline
\end{tabular}


Attachment 1. 600-111 Septic System Verification Sampling Results.

\begin{tabular}{|c|c|c|c|c|c|c|c|c|c|}
\hline \multirow[t]{2}{*}{ Constituent } & \multicolumn{3}{|c|}{$\begin{array}{c}\text { J16MN6 } \\
\text { Duplicate of J16MN5; } \\
\text { Sample Date 4/21/08 }\end{array}$} & \multicolumn{3}{|c|}{$\begin{array}{c}\text { J16MN7 } \\
\text { Sample Location 9; } \\
\text { Sample Date 4/21/08 } \\
\end{array}$} & \multicolumn{3}{|c|}{$\begin{array}{c}\text { J16MN8 } \\
\text { Sample Location 10; } \\
\text { Sample Date 4/21/08 }\end{array}$} \\
\hline & $\mu \mathrm{g} / \mathrm{kg}$ & $Q$ & PQL & $\mu \mathrm{g} / \mathrm{kg}$ & $\mathrm{Q}$ & $\mathrm{PQL}$ & $\mu \mathrm{g} / \mathrm{kg}$ & $\mathbf{Q}$ & PQL \\
\hline \multicolumn{10}{|c|}{ Polychlorinated Biphenyls } \\
\hline Aroclor -1016 & 14 & $\mathrm{U}$ & 14 & 14 & $\mathrm{U}$ & 14 & 14 & $\mathrm{U}$ & 14 \\
\hline Aroclor-1221 & 14 & $\mathrm{U}$ & 14 & 14 & $\mathrm{U}$ & 14 & 14 & $\mathrm{U}$ & 14 \\
\hline Aroclor- 1232 & 14 & $\mathrm{U}$ & 14 & 14 & $\mathrm{U}$ & 14 & 14 & $\mathrm{U}$ & 14 \\
\hline Aroclor- 1242 & 14 & $\mathrm{U}$ & 14 & 14 & $\mathrm{U}$ & 14 & 14 & $\mathrm{U}$ & 14 \\
\hline Aroclor- 1248 & 14 & $\mathrm{U}$ & 14 & 14 & $\mathrm{U}$ & 14 & 14 & $\mathrm{U}$ & 14 \\
\hline Aroclor- 1254 & 14 & $\mathrm{U}$ & 14 & 14 & $\mathrm{U}$ & 14 & 14 & $\mathrm{U}$ & 14 \\
\hline Aroclor -1260 & 14 & $\mathrm{U}$ & 14 & 14 & $\mathrm{U}$ & 14 & 14 & $\mathrm{U}$ & 14 \\
\hline \multicolumn{10}{|c|}{ Semivolatile Organic Analytes } \\
\hline 1,2,4-Trichlorobenzene & 350 & U & 350 & 340 & $\mathrm{U}$ & 340 & 350 & $\mathrm{U}$ & 350 \\
\hline 1,2-Dichlorobenzene & 350 & $\mathrm{U}$ & 350 & 340 & $\mathrm{U}$ & 340 & 350 & $\mathrm{U}$ & 350 \\
\hline 1,3-Dichlorobenzene & 350 & $\mathrm{U}$ & 350 & 340 & $\mathrm{U}$ & 340 & 350 & $\mathrm{U}$ & 350 \\
\hline 1,4-Dichlorobenzene & 350 & $\mathrm{U}$ & 350 & 340 & $\mathrm{U}$ & 340 & 350 & $\mathrm{U}$ & 350 \\
\hline 2,4,5-Trichlorophenol & 870 & $\mathrm{U}$ & 870 & 850 & $\mathrm{U}$ & 850 & 870 & $\mathrm{U}$ & 870 \\
\hline 2,4,6-Trichlorophenol & 350 & $\mathrm{U}$ & 350 & 340 & $\mathrm{U}$ & 340 & 350 & $\mathrm{U}$ & 350 \\
\hline 2,4-Dichlorophenol & 350 & $\mathrm{U}$ & 350 & 340 & $\mathrm{U}$ & 340 & 350 & $\mathrm{U}$ & 350 \\
\hline 2,4-Dimethylphenol & 350 & $\mathrm{U}$ & 350 & 340 & $\mathrm{U}$ & 340 & 350 & $\mathrm{U}$ & 350 \\
\hline 2,4-Dinitrophenol & 870 & $\mathrm{U}$ & 870 & 850 & $\mathrm{U}$ & 850 & 870 & $\mathrm{U}$ & 870 \\
\hline 2,4-Dinitrotoluene & 350 & $\mathrm{U}$ & 350 & 340 & $\mathrm{U}$ & 340 & 350 & $\mathrm{U}$ & 350 \\
\hline 2,6-Dinitrotoluene & 350 & $\mathrm{U}$ & 350 & 340 & $\bar{U}$ & 340 & 350 & $\mathrm{U}$ & 350 \\
\hline 2-Chloronaphthalene & 350 & $\mathrm{U}$ & 350 & 340 & $\mathrm{U}$ & 340 & 350 & $\mathrm{U}$ & 350 \\
\hline 2-Chlorophenol & 350 & $\mathrm{U}$ & 350 & 340 & $\mathrm{U}$ & 340 & 350 & $\mathrm{U}$ & 350 \\
\hline 2-Methylnaphthalene & 350 & $\mathrm{U}$ & 350 & 340 & $\mathrm{U}$ & 340 & 350 & U & 350 \\
\hline 2-Methylphenol (cresol, o-) & 350 & $\mathrm{U}$ & 350 & 340 & $\mathrm{U}$ & 340 & 350 & $\mathrm{U}$ & 350 \\
\hline 2-Nitroaniline & 870 & $\mathrm{U}$ & 870 & 850 & $\mathrm{U}$ & 850 & 870 & $\mathrm{U}$ & 870 \\
\hline 2-Nitrophenol & 350 & $\mathrm{U}$ & 350 & 340 & $\mathrm{U}$ & 340 & 350 & $\mathrm{U}$ & 350 \\
\hline 3,3'-Dichlorobenzidine & 350 & $\mathrm{U}$ & 350 & 340 & $\bar{U}$ & 340 & 350 & $\mathrm{U}$ & 350 \\
\hline 4-Methylphenol (p-cresol) & 350 & $\mathrm{U}$ & 350 & 340 & $\mathrm{U}$ & 340 & 350 & $\mathrm{U}$ & 350 \\
\hline 3-Nitroaniline & 870 & $\mathrm{U}$ & 870 & 850 & $\mathrm{U}$ & 850 & 870 & $\mathrm{U}$ & 870 \\
\hline 4,6-Dinitro-2-methylphenol & 870 & $\mathrm{U}$ & 870 & 850 & $\mathrm{U}$ & 850 & 870 & $\mathrm{U}$ & 870 \\
\hline 4-Bromophenyl-phenylether & 350 & $\mathrm{U}$ & 350 & 340 & $\mathrm{U}$ & 340 & 350 & $\mathrm{U}$ & 350 \\
\hline 4-Chloro-3-methylphenol & 350 & $\mathrm{U}$ & 350 & 340 & $\mathrm{U}$ & 340 & 350 & $\mathrm{U}$ & 350 \\
\hline 4-Chloroaniline & 350 & $\mathrm{U}$ & 350 & 340 & $\mathrm{U}$ & 340 & 350 & $\mathrm{U}$ & 350 \\
\hline 4-Chlorophenyl-phenylether & 350 & $\mathrm{U}$ & 350 & 340 & $\mathrm{U}$ & 340 & 350 & $\mathrm{U}$ & 350 \\
\hline & \multirow{4}{*}{\multicolumn{3}{|c|}{$\begin{array}{l}\text { Attachment } \\
\text { Originator } \\
\text { Checked } \\
\text { Calc. No. }\end{array}$}} & \multicolumn{3}{|c|}{1} & \multirow{4}{*}{$\begin{array}{l}\text { Sheet No. } \\
\text { Date } \\
\text { Date } \\
\text { Rev. No. }\end{array}$} & \multicolumn{2}{|c|}{7 of 8} \\
\hline & & & & \multicolumn{3}{|c|}{ H. M. Sulloway } & & \multicolumn{2}{|c|}{$08 / 03 / 08$} \\
\hline & & & & \multicolumn{3}{|c|}{ W.S. Thompson $/ 1$ t } & & \multicolumn{2}{|c|}{$08 / 03 / 08$} \\
\hline & & & & \multicolumn{3}{|c|}{$0600 X-C A-V 0070$} & & \multicolumn{2}{|c|}{1} \\
\hline
\end{tabular}


Attachment 1. 600-111 Septic System Verification Sampling Results.

\begin{tabular}{|c|c|c|c|c|c|c|c|c|c|}
\hline \multirow[t]{2}{*}{ Constituent } & \multicolumn{3}{|c|}{$\begin{array}{c}\text { J16MN6 } \\
\text { Duplicate of J16MN5; } \\
\text { Sample Date } 4 / 21 / 08\end{array}$} & \multicolumn{3}{|c|}{$\begin{array}{c}\text { J16MN7 } \\
\text { Sample Location 9; } \\
\text { Sample Date 4/21/08 }\end{array}$} & \multicolumn{3}{|c|}{$\begin{array}{c}\text { J16MN8 } \\
\text { Sample Location 10; } \\
\text { Sample Date 4/21/08 }\end{array}$} \\
\hline & $\mathrm{gg} / \mathrm{kg}$ & $Q$ & PQL & $\mu \mathrm{g} / \mathrm{kg}$ & $\mathbf{Q}$ & PQL & $\mu \mathrm{g} / \mathrm{kg}$ & $\mathbf{Q}$ & PQL \\
\hline \multicolumn{10}{|c|}{ Semivolatile Organic Analytes (continued) } \\
\hline 4-Nitroaniline & 870 & $\mathrm{U}$ & 870 & 850 & $\mathrm{U}$ & 850 & 870 & $\bar{U}$ & 870 \\
\hline 4-Nitrophenol & 870 & $\mathrm{U}$ & 870 & 850 & $\mathrm{U}$ & 850 & 870 & $\mathrm{U}$ & 870 \\
\hline Acenaphthene & 350 & $U$ & 350 & 340 & $\mathrm{U}$ & 340 & 350 & $\mathrm{U}$ & 350 \\
\hline Acenaphthylene & 350 & $\mathrm{U}$ & 350 & 340 & $\mathrm{U}$ & 340 & 350 & $\mathrm{U}$ & 350 \\
\hline Anthracene & 350 & $\mathrm{U}$ & 350 & 340 & $\mathrm{U}$ & 340 & 350 & $\mathrm{U}$ & 350 \\
\hline Benzo(a)anthracene & 350 & $\mathrm{U}$ & 350 & 340 & $\mathrm{U}$ & 340 & 350 & $\bar{U}$ & 350 \\
\hline Benzo(a)pyrene & 350 & $\mathrm{U}$ & 350 & 340 & $\mathrm{U}$ & 340 & 350 & $\mathrm{U}$ & 350 \\
\hline Benzo(b)fluoranthene & 350 & $\mathrm{U}$ & 350 & 340 & $\mathrm{U}$ & 340 & 350 & $\mathrm{U}$ & 350 \\
\hline Benzo(g,h,i)perylene & 350 & $\mathrm{U}$ & 350 & 340 & $\mathrm{U}$ & 340 & 350 & $\mathrm{U}$ & 350 \\
\hline Benzo(k)fluoranthene & 350 & $\mathrm{U}$ & 350 & 340 & $\mathrm{U}$ & 340 & 350 & $\mathrm{U}$ & 350 \\
\hline Bis(2-chloro-1-methylethyl)ether & 350 & $\mathrm{U}$ & 350 & 340 & $\mathrm{U}$ & 340 & 350 & $\mathrm{U}$ & 350 \\
\hline Bis(2-chloroethoxy)methane & 350 & $\mathrm{U}$ & 350 & 340 & $\mathrm{U}$ & 340 & 350 & $\mathrm{U}$ & 350 \\
\hline Bis(2-chloroethyl) ether & 350 & $\mathrm{U}$ & 350 & 340 & $\mathrm{U}$ & 340 & 350 & $\mathrm{U}$ & 350 \\
\hline Bis(2-ethylhexyl) phthalate & 17 & $\mathrm{~J}$ & 350 & 340 & $\mathrm{U}$ & 340 & 62 & $\mathrm{~J}$ & 350 \\
\hline Butylbenzylphthalate & 350 & $\mathrm{U}$ & 350 & 340 & $\mathrm{U}$ & 340 & 350 & $\mathrm{U}$ & 350 \\
\hline Carbazole & 350 & $\mathrm{U}$ & 350 & 340 & $\mathrm{U}$ & 340 & 350 & $\mathrm{U}$ & 350 \\
\hline Chrysene & 350 & $\mathrm{U}$ & 350 & 340 & $\mathrm{U}$ & 340 & 350 & $\mathrm{U}$ & 350 \\
\hline Dibenz $(\mathrm{a}, \mathrm{h})$ anthracene & 350 & $\mathrm{U}$ & 350 & 340 & $\mathrm{U}$ & 340 & 350 & $\mathrm{U}$ & 350 \\
\hline Dibenzofuran & 350 & $\mathrm{U}$ & 350 & 340 & $\mathrm{U}$ & 340 & 350 & $\bar{U}$ & 350 \\
\hline Diethylphthalate & 350 & $\mathrm{U}$ & 350 & 340 & $\mathrm{U}$ & 340 & 350 & $\mathrm{U}$ & 350 \\
\hline Dimethylphthalate & 350 & $\mathrm{U}$ & 350 & 340 & $\mathrm{U}$ & 340 & 350 & $\mathrm{U}$ & 350 \\
\hline Di-n-butylphthalate & 350 & $\mathrm{U}$ & 350 & 340 & $\mathrm{U}$ & 340 & 350 & $\mathrm{U}$ & 350 \\
\hline Di-n-octylphthalate & 350 & $\mathrm{U}$ & 350 & 340 & $\mathrm{U}$ & 340 & 350 & $\mathrm{U}$ & 350 \\
\hline Fluoranthene & 350 & $\bar{U}$ & 350 & 340 & $\mathrm{U}$ & 340 & 350 & $\mathrm{U}$ & 350 \\
\hline Fluorene & 350 & $\mathrm{U}$ & 350 & 340 & $\mathrm{U}$ & 340 & 350 & $\mathrm{U}$ & 350 \\
\hline Hexachlorobenzene & 350 & $\mathrm{U}$ & 350 & 340 & $\mathrm{U}$ & 340 & 350 & $\mathrm{U}$ & 350 \\
\hline Hexachlorobutadiene & 350 & $\mathrm{U}$ & 350 & 340 & $\mathrm{U}$ & 340 & 350 & $\mathrm{U}$ & 350 \\
\hline Hexachlorocyclopentadiene & 350 & $\mathrm{U}$ & 350 & 340 & $\mathrm{U}$ & 340 & 350 & $\mathrm{U}$ & 350 \\
\hline Hexachloroethane & 350 & $\mathrm{U}$ & 350 & 340 & $\mathrm{U}$ & 340 & 350 & $\mathrm{U}$ & 350 \\
\hline Indeno(1,2,3-cd)pyrene & 350 & $\mathrm{U}$ & 350 & 340 & $\mathrm{U}$ & 340 & 350 & $\mathrm{U}$ & 350 \\
\hline Isophorone & 350 & $\mathrm{U}$ & 350 & 340 & $\mathrm{U}$ & 340 & 350 & $\mathrm{U}$ & 350 \\
\hline Naphthalene & 350 & $\mathrm{U}$ & 350 & 340 & $\mathrm{U}$ & 340 & 350 & U & 350 \\
\hline Nitrobenzene & 350 & $\mathrm{U}$ & 350 & 340 & $\bar{U}$ & 340 & 350 & $\mathrm{U}$ & 350 \\
\hline N-Nitroso-di-n-dipropylamine & 350 & $\mathrm{U}$ & 350 & 340 & $\mathrm{U}$ & 340 & 350 & $\mathrm{U}$ & 350 \\
\hline N-Nitrosodiphenylamine & 350 & $\mathrm{U}$ & 350 & 340 & $\mathrm{U}$ & 340 & 350 & $\bar{U}$ & 350 \\
\hline Pentachlorophenol & 870 & $\mathrm{U}$ & 870 & 850 & $\mathrm{U}$ & 850 & 870 & $\mathrm{U}$ & 870 \\
\hline Phenanthrene & 350 & $\mathrm{U}$ & 350 & 340 & $\mathrm{U}$ & 340 & 350 & $\mathrm{U}$ & 350 \\
\hline Phenol & 350 & $\mathrm{U}$ & 350 & 340 & $\mathrm{U}$ & 340 & 350 & $\mathrm{U}$ & 350 \\
\hline Pyrene & 18 & $J$ & 350 & 340 & $\mathrm{U}$ & 340 & 350 & $\mathrm{U}$ & 350 \\
\hline
\end{tabular}

Attachment Originator

Checked

Calc. No.

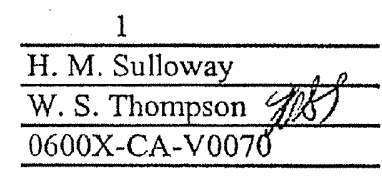

Sheet No.

Date

Date

Rev. No.

$\frac{8 \text { of } 8}{\frac{08 / 03 / 08}{08 / 03 / 08}}$




\section{CALCULATION COVER SHEET}

Project Title: 600 Area Field Remediation

Job No. 14655

Area: 600 Area

Discipline: Environmental

${ }^{*}$ Calculation No: 0600X-CA-V0071

Subject: 600-111 and UPR-600-16 Cleanup Verification Hazard Quotient and Carcinogenic Risk Calculations

Computer Program: Excel

The attached calculations have been generated to document compliance with established cleanup levels. These calculations should be used in conjunction with other relevant documents in the administrative record.

Committed Calculation $\bar{x}$

Preliminary $\Gamma$

Superseded $\Gamma$

Voided $\Gamma$

\begin{tabular}{|c|c|c|c|c|c|c|}
\hline Rev. & Sheet Numbers & Originator & Checker & Reviewer & Approval & Date \\
\hline 0 & $\begin{array}{c}\text { Cover }=1 \\
\text { Sheets }=3 \\
\text { Total }=4\end{array}$ & H. M. Sulloway & L. D. Habel & NA & J. D. Fancher & $4 / 27 / 08$ \\
\hline 1 & $\begin{array}{c}\text { Cover }=1 \\
\text { Sheets }=3 \\
\text { Total }=4 \\
\end{array}$ & W. SThompson & $\begin{array}{l}\text { H.M. Sulloway } \\
\text {-fikisulloway }\end{array}$ & NA & J.D Fagher & $5 / 48$ \\
\hline & & & & & & \\
\hline & & & & & & \\
\hline & & & & & & \\
\hline & & & & & & \\
\hline
\end{tabular}

\section{SUMMARY OF REVISION}


Washington Closure Hanford if CALCULATION SHEET

\begin{tabular}{|c|c|c|c|c|c|c|c|}
\hline Originator: & W.S. Thompson Te & Date: & $8 / 4 / 08$ & Calc. No.: & $0600 \mathrm{X}-\mathrm{CA}-\mathrm{V} 007 \mathrm{~A}$ & Rev.: & 1 \\
\hline Project: & 600 Area Field Remediation & Job No: & 14655 & Checked: & H. M. Sullowayd & Date: & $8 / 4 / 08$ \\
\hline Subject: & $\begin{array}{l}600-111 \text { and UPR-600-16 Cl } \\
\text { Calculations }\end{array}$ & InC & $\operatorname{ard} Q$ & nd calc & genic Risk & Sheet I & of 3 \\
\hline
\end{tabular}

\section{PURPOSE:}

Provide documentation to support the calculation of the hazard quotient (HQ) and carcinogenic (excess cancer) risk values for the 600-111 and UPR-600-16 waste sites. In accordance with the remedial action goals (RAGs) in the remedial design report/remedial action work plan (RDR/RAWP) (DOE-RL 2005), the following criteria must be met:

1) An HQ of $<1.0$ for all individual noncarcinogens

2) A cumulative HQ of $<1.0$ for noncarcinogens

3) An excess cancer risk of $<1 \times 10^{-6}$ for individual carcinogens

4) A cumulative excess cancer risk of $<1 \times 10^{-5}$ for carcinogens.

\section{GIVEN/REFERENCES:}

1) DOE-RL, 2005, Remedial Design Report/Remedial Action Work Plan for the 100 Areas, DOE/RL-96-17, Rev. 5, U.S. Department of Energy, Richland Operations Office, Richland, Washington.

2) WAC 173-340, "Model Toxics Control Act - Cleanup," Washington Administrative Code, 1996.

3) WCH, 2008a, 600-11, P-11 Critical Mass Laboratory Crib, Cleanup Verification 95\% UCL Calculation, 0600X-CA-V0070, Washington Closure Hanford, Richland, Washington.

4) WCH, 2008b, Remaining Sites Verification Package for the 600-111, P-11 Critical Mass Laboratory Crib, and UPR-600-16, Fire and Contamination Spread Waste Sites, Attachment to Waste Site Reclassification Form 2004-065, Washington Closure Hanford, Richland, Washington.

\section{SOLUTION:}

1) Calculate an HQ for each noncarcinogenic constituent detected above background and compare it to the individual HQ of $<1.0$ (DOE-RL 2005).

2) Sum the HQs and compare to the cumulative HQ criterion of $<1.0$.

3) Calculate an excess cancer risk value for each carcinogenic constituent detected above background and compare it to the individual excess cancer risk criterion of $<1 \times 10^{-6}$ (DOE-RL 2005).

4) Sum the excess cancer risk values and compare to the cumulative cancer risk criterion of $<1 \times 10^{-5}$. 
Washington Closure Hanford 10 CALCULATION SHEET

\begin{tabular}{|c|c|c|c|c|c|c|c|}
\hline Originator: & W.S. Thompson & Date: & $8 / 4 / 08$ & Calc. No.: & $0600 \mathrm{X}-\mathrm{CA}-\mathrm{V} 00 \mathrm{Z}$ & Rev.: & 1 \\
\hline Project: & 600 Area Field Remediation & Job No: & 14655 & Checked: & H. M. Sulloway d th & Date: & $8 / 4 / 08$ \\
\hline Subject: & $\begin{array}{l}600-111 \text { and } U P R-600-16 \mathrm{Cl} \\
\text { Calculations }\end{array}$ & rification & zard & and Carcin & genic Risk & \multicolumn{2}{|c|}{ Sheet No. 2 of 3} \\
\hline
\end{tabular}

\section{METHODOLOGY:}

HQ and carcinogenic risk calculations were calculated for the 600-111 and UPR-600-16 waste sites using either the statistically determined or maximum value from the verification samples collected for the 600-111 septic system (Areas 5 and 6) after remediation (WCH 2008a) or the maximum value from Area 1 (120 Experimental Building), Area 2 (Crib), or Area 3 (123 Control Building) confirmatory samples (WCH 2008b), whichever value was greater. Of the nonradionuclide contaminants of potential concern (COPC) barium, copper, nickel, and zinc required the HQ calculation because they were quantified above background. Additionally, boron and molybdenum required the HQ calculation because these COPCs were detected and a Washington State or Hanford Site background value is not available. Bis(2-ethylhexyl)phthalate, isophorone and pyrene required the HQ and risk calculations because they were detected and cannot be attributed to natural occurrence. Lead does not have a reference dose for calculation of a hazard quotient because toxic effects of lead are correlated with blood-lead levels rather than exposure levels or daily intake. As a result, the maximum lead concentration is reported but not included in the hazard quotient calculation. All other site nonradionuclide COPCs were not detected or were quantified below background levels. An example of the HQ and risk calculations is presented below:

1) For example, the statistical result for molybdenum $(1.0 \mathrm{mg} / \mathrm{kg})$, divided by the noncarcinogenic $\mathrm{RAG}$ value of $400 \mathrm{mg} / \mathrm{kg}$ (calculated in accordance with the noncarcinogenic toxic effects WAC 173-340-740[3]), is $2.5 \times 10^{-3}$. Comparing this value, and all other individual values, to the requirement of $<1.0$, this criterion is met.

2) After the HQ calculations are completed for the appropriate analytes, the cumulative HQ is obtained by summing the individual values. (To avoid errors due to intermediate rounding, the individual HQ values prior to rounding are used for this calculation.) The sum of the HQ values is $6.6 \times 10^{-2}$. Comparing this values to the requirement of $<1.0$, this criterion is met.

3) To calculate the excess cancer risk, the maximum or statistical value is divided by the carcinogenic RAG value, then multiplied by $1 \times 10^{-6}$. For example, the maximum value for isophorone is $0.020 \mathrm{mg} / \mathrm{kg}$; divided by $1,050 \mathrm{mg} / \mathrm{kg}$, and multiplied as indicated, is $1.9 \times 10^{-11}$. Comparing this value to the requirement of $<1 \times 10^{-6}$, this criterion is met.

4) After these calculations are completed for the carcinogenic analytes, the cumulative excess cancer risk is obtained by summing the individual values. The sum of the excess cancer risk values is $1.3 \times 10^{-9}$. Comparing this value to the requirement of $<1 \times 10^{-5}$, this criterion is met.

\section{RESULTS:}

1) List individual noncarcinogens and corresponding HQs $>1.0$ : None

2) List the cumulative noncarcinogenic HQ $>1.0$ : None

3) List individual carcinogens and corresponding excess cancer risk $>1 \times 10^{-6}$ : None

4) List the cumulative excess cancer risk for carcinogens $>1 \times 10^{-5}$ : None.

Table 1 shows the results of the calculation. 
Washington Closure Hanford CALCULATION SHEET Originator: W.S. Thompson Project: 600 Area Field Remediation

Project:

\begin{tabular}{|l|r|r|r|r|r|r|}
\hline & Date: & $8 / 4 / 08$ & Calc. No.: & O600X-CA-V0071 & Rev.: & 1 \\
\hline ation & Job No: & 14655 & Checked: & H. M. Sullowaytw & Date: & $8 / 4 / 08$ \\
\hline
\end{tabular}

\section{Table 1. Hazard Quotient and Excess Cancer Risk Results for the 600-111 and} UPR-600-16 Waste Site.

2

3

4

5

6

7

8

9

10

11

12

13

14

15

16

17

18

\begin{tabular}{|c|c|c|c|c|c|}
\hline Contaminants of Concern ${ }^{a}$ & $\begin{array}{c}\text { Maximum or } \\
\text { Statistical Value }^{a} \\
(\mathrm{mg} / \mathrm{kg})\end{array}$ & $\begin{array}{c}\text { Noncarcinogen } \\
\text { RAG }^{\mathbf{b}} \\
(\mathrm{mg} / \mathrm{kg})\end{array}$ & $\begin{array}{l}\text { Hazard } \\
\text { Quotient }\end{array}$ & $\begin{array}{c}\text { Carcinogen } \\
\text { RAG }^{b} \\
(\mathrm{mg} / \mathrm{kg})\end{array}$ & $\begin{array}{c}\text { Carcinogen } \\
\text { Risk }\end{array}$ \\
\hline \multicolumn{6}{|c|}{ Metals } \\
\hline Barium & 154 & 5,600 & $2.8 \mathrm{E}-02$ & - & - \\
\hline Boron & 2.7 & 16,000 & $1.7 \mathrm{E}-04$ & - & -- \\
\hline Copper & 39.6 & 2,960 & $1.3 \mathrm{E}-02$ & - & - \\
\hline Lead $^{\mathrm{c}}$ & 142 & 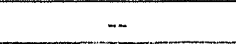 & - & - & - \\
\hline Molybdenum & 1.0 & 400 & $2.5 \mathrm{E}-03$ & - & - \\
\hline Nickel & 23.6 & 1,600 & $1.5 \mathrm{E}-02$ & - & $\cdots$ \\
\hline Zinc & 177 & 24,000 & $7.4 \mathrm{E}-03$ & $-\infty$ & -- \\
\hline \multicolumn{6}{|c|}{ Sempolatiles } \\
\hline Bis(2-ethylhexyl) phthalate & 0.088 & 1,600 & $5.5 \mathrm{E}-05$ & 71.4 & $1.2 \mathrm{E}-09$ \\
\hline Isophorone & 0.020 & 16,000 & $1.3 \mathrm{E}-06$ & 1,050 & $1.9 \mathrm{E}-11$ \\
\hline Pyrene & 0.025 & 2,400 & $1.0 \mathrm{E}-05$ & -- & $-\infty$ \\
\hline \multicolumn{6}{|c|}{ 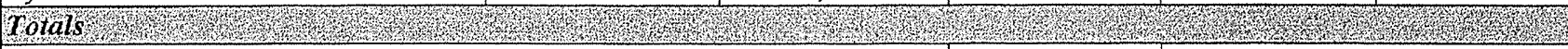 } \\
\hline \multicolumn{3}{|c|}{ Cumulative Hazard Quotient: } & $6.6 \mathrm{E}-02$ & & \\
\hline \multicolumn{5}{|l|}{ Cumulative Excess Cancer Risk: } & 1.3E-09 \\
\hline
\end{tabular}

Notes:

$"=$ From WCH (2008a, 2008b).

${ }^{b}=$ Value obtained from the RDR/RAWP (DOE-RL 2005) or Washington Administrative Code (WAC) 173-340-740(3), Method B, 1996, unless otherwise noted.

$c=$ No oral reference dose (RfD) or cancer slope factor (CSF)

-- not applicable

$\mathrm{RAG}=$ remedial action goal

\section{CONCLUSION:}

This calculation demonstrates that the 600-111 and UPR-600-16 waste sites meet the requirements for the hazard quotients and carcinogenic (excess cancer) risk as identified in the RDR/RAWP

(DOE-RL 2005). 


\section{CALCULATION COVER SHEET}

Project Title 600 Area Remaining Sites Waste Site Evaluation Job No. 22192 Area 600 Area; 100-IU-6 Operable Unit

Discipline Environmental *Calc. No. 0600X-CA-V0043

Subject $600-111$, P-11 Critical Mass Laboratory RESRAD Calculation Brief

Computer Program RESRAD Program No. Version 6.21

The attached calculations have been generated to document compliance with established cleanup levels.

These documents should be used in conjunction with other relevant documents in the administrative record.

\section{Committed Calculation $\otimes \quad$ Preliminary $\square \quad$ Superseded $\square$}

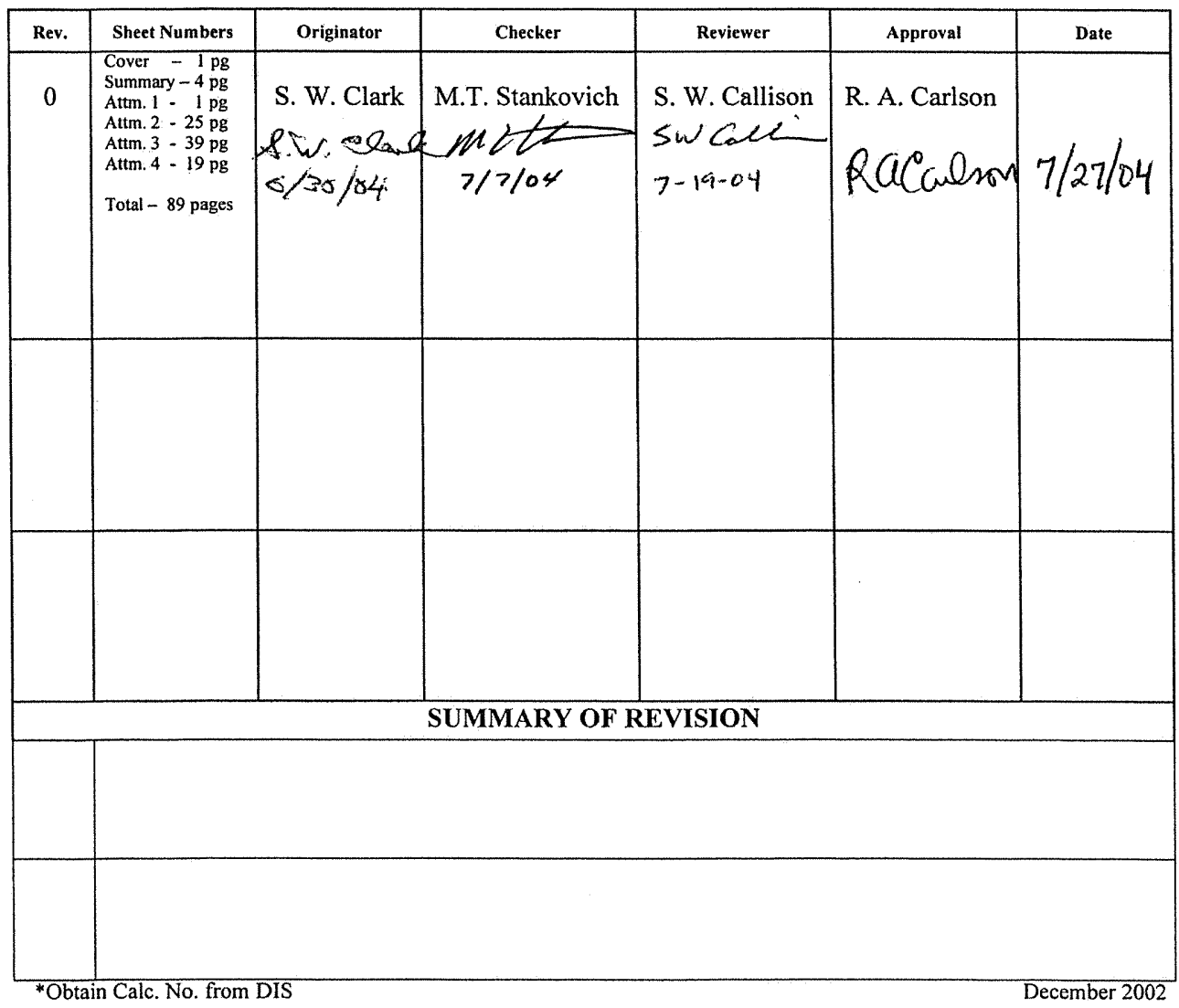

DE01-437.03 
Bechtel Hanford, Inc. CALCULATION SHEET

Hansooras Bechtel Hanford, Inc.

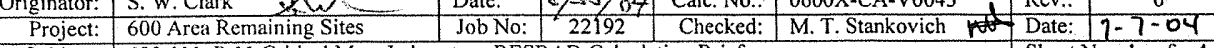

Subject: $600-111, \mathrm{P}-11$ Critical Mass Laboratory RESRAD Calculation Brief

Sheet No 1 of 4

\section{PURPOSE:}

Calculate dose, risk, and potential groundwater impacts of residual radionuclides at the $600-111$, P-11 Critical Mass Laboratory site over a period of 1,000 years.

\section{GIVEN/REFERENCES:}

1) Maximum contaminant levels for the 600-111 P-11 Critical Mass Laboratory site presented in Attachment 1.

2) Remedial Design Report/Remedial Action Work Plan for the 100 Area (RDR/RAWP), DOE/RL-96-17, Rev. 4, U.S. Department of Energy, Richland Operations Office, Richland, Washington.

3) RESidual RADioactivity (RESRAD) computer code, version 6.21 , to calculate compliance with residual radioactivity guidelines, developed for the U.S. Department of Energy by the Environmental Assessment Division of Argonne National Laboratory, Argonne, Illinois.

4) Calculation of relative individual $\mathrm{Pu}-239$ and $\mathrm{Pu}-240$ activities from the reported $\mathrm{Pu}-239 / 240$ results per Ratios of Plutonium Isotopes at 100 Areas Remedial Action Sites, Calculation No. 0100B-CA-V0013, Bechtel Hanford, Inc., Richland, Washington.

5) Sample design data for the 600-111, P-11 Critical Mass Laboratory site from the Work Instruction for Waste Site 600-111, P-11 Critical Mass Laboratory Crib and Waste Site UPR600-16, Fire And Contamination Spread, Work Instruction No. 0600X-WI-G004.

\section{SOLUTION:}

1) A single RESRAD run was performed to model the radionuclides for the shallow vadose zone soil horizon. Table 1 shows the waste site parameters used for the RESRAD modeling. Evaluation of radionuclide dose and risk is performed using no cover material because the contamination is in the shallow zone ( $<4.6 \mathrm{~m}$ below the surface) and is therefore presumed to be accessible in the 100 Area unrestricted land use scenario. Input factors for modeling are shown in the "Summary" section of the RESRAD "Mixture Sums and Single Radionuclide Guidelines" printouts in Attachment 1 to this Calculation Summary.

2) The year when the peak dose (or concentration) occurs from each individual radionuclide COPC is determined by a preliminary run. This year is then added for all final RESRAD runs. For the direct exposure pathways (i.e. soil ingestion and inhalation and external radiation) and the water dependent pathways (i.e. drinking water and food ingestion) the peak year occurred at year zero (year 2004) for all COPCs. 
Bechtel Hanford, Inc. CALCULATION SHEET

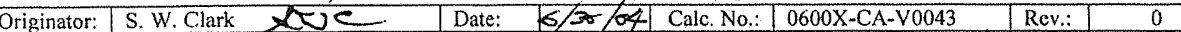

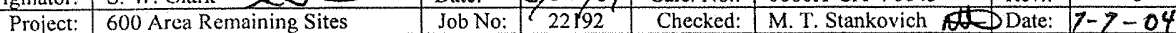

Subject: $600-111, \mathrm{P}-11$ Critical Mass Laboratory RESRAD Calculation Brief Sheet No. 2 of 4

Table 1. Waste Site Dimensions for RESRAD Modeling

\begin{tabular}{|l|c|c|l|}
\hline \multicolumn{1}{|c|}{ Parameter } & Units & Value & \multicolumn{1}{c|}{ Comments } \\
\hline Cover Depth & $\mathrm{m}$ & 0 & \\
\hline Area of Contaminated Zone $(\mathrm{CZ})$ & $\mathrm{m}^{2}$ & 8,100 & Length $\mathrm{x}$ Width \\
\hline \multicolumn{4}{|c|}{ Length Parallel to Aquifer Flow } \\
\hline Based on Square Root of CZ Area & $\mathrm{m}$ & 90 & \\
\hline \multicolumn{4}{|c|}{ Elevations of Vadose Zone Horizons } \\
\hline Thickness: Contaminated Zone & $\mathrm{m}$ & 4.6 & Thickness: Surface to bottom of waste \\
\hline Thickness: Unsaturated Zone & $\mathrm{m}$ & 8.2 & Vadose zone beneath bottom of waste \\
\hline
\end{tabular}

\section{METHODOLOGY:}

1) $\mathrm{Pu}-239 / 240$ Conversion: The relative individual $\mathrm{Pu}-239$ and $\mathrm{Pu}-240$ activities were calculated from the combined $\mathrm{Pu}-239 / 240$ results reported. The calculations were performed in accordance with calculation brief No. 0100B-CA-V0013. The relative activities for Pu-239 and $\mathrm{Pu}-240$ were calculated by multiplying the cleanup verification value for $\mathrm{Pu}-239 / 240$ by 0.807 and 0.193 , respectively. Table 2 shows the results from this calculation.

\begin{tabular}{|c|c|c|c|}
\hline \multicolumn{5}{|c|}{ Table 2. Conversion of Pu-239/240 to Relative Pu-239 and Pu-240 Activities } \\
\hline $\begin{array}{c}\text { Vadose Zone } \\
\text { Horizon }\end{array}$ & $\begin{array}{c}\text { Pu-239/240 Activity } \\
\text { (pCi/g) }\end{array}$ & $\begin{array}{c}\text { Pu-239, (pCi/g) } \\
(0.807 \text { multiplier) }\end{array}$ & $\begin{array}{c}\text { Pu-240, (pCi/g) } \\
(0.193 \text { multiplier) }\end{array}$ \\
\hline Shallow Zone & 0.816 & 0.659 & 0.157 \\
\hline
\end{tabular}

2) A run of RESRAD version 6.21 was completed for shallow zone soils using the radionuclide concentrations shown in Table 3. RESRAD numerical output reports for dose, risk, and concentration for the shallow zone are presented in the Attachments to this calculation summary.

\begin{tabular}{|c|c|}
\hline COPC & $\begin{array}{l}\text { Soil Radionuclide Activity } \\
(\mathrm{pCi} / \mathrm{g})\end{array}$ \\
\hline $\mathrm{Am}-241$ & 0.226 \\
\hline Cs-137 & 0.361 \\
\hline Pu-239 & 0.659 \\
\hline Pu-240 & 0.157 \\
\hline
\end{tabular}

17

Several radionuclides that are not included in the RESRAD evaluation also had reported analytical results above minimum detectable activities. Potassium- 40 occurs as part of natural background and is not included in evaluation of radiation dose or risk above background. 
Maximum activities of Radium-226 and Thorium-232 are below Hanford Site background ( 0.815 $\mathrm{pCi} / \mathrm{g}$ and $1.32 \mathrm{pCi} / \mathrm{g}$, respectively). Radium-228 and Thorium-228 are daughter products of Thorium-232 and will be in secular equilibrium with their parent isotope so they are not included in evaluation of radiation dose or risk above background.

\section{RESULTS:}

1) Radionuclide "All Pathways" Dose Rate: The "all pathways" (maximum) dose rates are shown in Table 4. The maximum all-pathways dose rate for the shallow zone is 1.32 $\mathrm{mrem} / \mathrm{yr}$ which occurs at year zero (2004).

\begin{tabular}{|c|c|c|c|c|c|c|c|c|c|}
\hline \multicolumn{10}{|c|}{ Table 4. All Pathways Dose Rate (mrem/yr) } \\
\hline $\begin{array}{c}\text { RESRAD } \\
\text { Run \# }\end{array}$ & \multicolumn{8}{c|}{ "All Pathways" Dose Contributions in mrem/yr at each time slice (yr). } \\
\cline { 2 - 10 } & 0 & 1 & 3 & 10 & 14 & 30 & 100 & 300 & 1000 \\
\hline 1 & $1.32 \mathrm{E}+00$ & $1.30 \mathrm{E}+00$ & $1.26 \mathrm{E}+00$ & $1.14 \mathrm{E}+00$ & $1.08 \mathrm{E}+00$ & $8.80 \mathrm{E}-01$ & $5.22 \mathrm{E}-01$ & $4.06 \mathrm{E}-01$ & $3.38 \mathrm{E}-01$ \\
\hline
\end{tabular}

12

13

\begin{tabular}{|c|c|c|c|c|c|c|c|c|c|c|}
\hline \multirow{2}{*}{ COPC } & \multicolumn{9}{|c|}{ Predicted Groundwater Concentrations in $\mathrm{pCi} / \mathrm{L}$ at Each Time Slice (yr) } & \multirow{2}{*}{$\begin{array}{l}\mathrm{RAGs}^{\mathrm{n}} \\
(\mathrm{pCi} / \mathrm{L})\end{array}$} \\
\hline & 0 & 1 & 3 & 8 & 14 & 43 & 100 & 300 & 1000 & \\
\hline Am-241 & 0 & 0 & 0 & 0 & 0 & 0 & 0 & 0 & 0 & 1.2 \\
\hline Cs-137 & 0 & 0 & 0 & 0 & 0 & 0 & 0 & 0 & 0 & 60 \\
\hline Pu-239 & 0 & 0 & 0 & 0 & 0 & 0 & 0 & 0 & 0 & 1.2 \\
\hline Pu-240 & 0 & 0 & 0 & 0 & 0 & 0 & 0 & 0 & 0 & 1.2 \\
\hline
\end{tabular}

"Value is the remedial action goal (RAG) from the RDR/RAWP based upon applicable groundwater cleanup levels.

Table 5. Radionuclide Excess Lifetime Cancer Risk

\begin{tabular}{|c|c|c|c|c|c|c|c|c|c|}
\hline \multirow{2}{*}{$\begin{array}{c}\text { RESRAD } \\
\text { Run } \#\end{array}$} & \multicolumn{8}{|c|}{ Excess Cancer Risk at Each Time Slice (yr) } \\
\cline { 2 - 9 } & 0 & 1 & 3 & 10 & 14 & 30 & 100 & 300 & 1000 \\
\hline 1 & $1.49 \mathrm{E}-05$ & $1.45 \mathrm{E}-05$ & $1.39 \mathrm{E}-05$ & $1.20 \mathrm{E}-05$ & $1.10 \mathrm{E}-05$ & $7.84 \mathrm{E}-06$ & $2.25 \mathrm{E}-06$ & $8.33 \mathrm{E}-07$ & $6.66 \mathrm{E}-07$ \\
\hline
\end{tabular}

3) Radionuclide Groundwater Protection: The radionuclide concentrations in groundwater calculated by the RESRAD model are summarized in Table 6. The RESRAD model predicts that no radionuclide reaches groundwater within 1,000 years.

24 


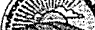

CALCULATION SHEET

\begin{tabular}{|c|c|c|c|c|c|c|c|}
\hline Prig & $8 x)^{2}$ & Date: & $5 / 20 / 6$ & Calc. No.: & $0600 \mathrm{X}-\mathrm{CA}-\mathrm{V} 0043$ & Rev.: & 0 \\
\hline & 600 Area Remaining Sites & Job No: & 22152 & Checked: & M.T. Stankovich & Date: & \\
\hline
\end{tabular}

Subject: $600-111$, P-11 Critical Mass Laboratory RESRAD Calculation Brief

\section{CONCLUSIONS:}

- The "all pathways" (maximum) dose rate shown in Table 4 is $1.32 \mathrm{mrem} / \mathrm{yr}$ at year zero (2004).

- The dominant pathway for the dose rate is direct exposure to external gamma radiation.

- The primary radionuclide contributing to the direct exposure pathways is cesiun-137.

- None of the site COCs are projected to exceed remedial action goals (RAGs).

- Maximum combined shallow and deep zone excess lifetime cancer risk $\left(1.49 \times 10^{-5}\right)$ occurs at year zero (2004).

- None of the radionuclide contaminants of concern are calculated to reach groundwater in the 1,000 years of the RESRAD model run (Table 6).

\section{ATTACHMENTS:}

1. Maximum Contaminant Levels at 600-111, P-11 Critical Mass Laboratory remediation site. (1 page)

2. RESRAD Output: Run \#1, 600-111, P-11 Critical Mass Laboratory Shallow Zone Radionuclides - Mixture Sums and Single Radionuclide Guidelines (25 pages)

3. RESRAD Output: Run \#1, 600-111, P-11 Critical Mass Laboratory Shallow Zone Radionuclides - Intake Quantities and Health Risk Factors (39 pages)

4. RESRAD Output: Run \#1,600-111, P-11 Critical Mass Laboratory Shallow Zone Radionuclides - Concentration of Radionuclides (19 pages) 


\section{ATTACHMENT 1}

600-111 Data Summary Table

\begin{tabular}{|c|c|c|c|c|c|c|c|c|c|c|c|c|c|c|}
\hline \multirow{2}{*}{$\begin{array}{c}\text { Sample } \\
\text { Area }\end{array}$} & \multirow{2}{*}{$\begin{array}{l}\text { HEIS } \\
\text { Number }\end{array}$} & \multirow{2}{*}{$\begin{array}{l}\text { Sample } \\
\text { Date }\end{array}$} & \multicolumn{3}{|c|}{ Americium-241 } & \multicolumn{3}{|c|}{ Americium-241 GEA } & \multicolumn{3}{|c|}{ Cesium-137 } & \multicolumn{3}{|c|}{ Cobalt-60 } \\
\hline & & & $\mathrm{pCi} / \mathrm{g}$ & Q & MDA & $\mathrm{pCi} / \mathrm{g}$ & 0 & MDA & $\mathrm{pCi} / \mathrm{g}$ & $Q$ & MDA & $\mathrm{pCi} / \mathrm{g}$ & Q & MDA \\
\hline $\begin{array}{l}\text { Equipment } \\
\text { Blank }\end{array}$ & J01F82 & $4 / 29 / 04$ & 0.095 & $u$ & 0.24 & 0.08 & U & 0.08 & 0.022 & $U$ & 0.022 & 0.025 & $U$ & 0.025 \\
\hline Area 6 & J01F83 & $4 / 29 / 04$ & 0.03 & $\mathrm{U}$ & 0.23 & 0.076 & $\mathrm{U}$ & 0.076 & 0.018 & $U$ & 0.018 & 0.019 & $\mathrm{U}$ & 0.019 \\
\hline Area 5 & J01F84 & $4 / 29 / 04$ & -0.026 & U & 0.2 & 0.36 & $U$ & 0.36 & 0.14 & $U$ & 0.14 & 0.13 & $\mathrm{U}$ & 0.13 \\
\hline Area 3 & J01F85 & $5 / 5 / 04$ & 0 & $\mathrm{U}$ & 0.17 & 0.11 & $U$ & 0.11 & 0.361 & & 0.026 & 0.029 & $u$ & 0.029 \\
\hline Area 1 & $301 F 70$ & $5 / 5 / 04$ & 0 & U & 0.17 & 0.19 & $U$ & 0.19 & 0.025 & U & 0.025 & 0.027 & $u$ & 0.027 \\
\hline Area 2 & J01F71 & $5 / 10 / 04$ & 0.226 & & 0.22 & 0.048 & $U$ & 0.048 & 0.026 & $\mathrm{U}$ & 0.026 & 0.026 & $U$ & 0.026 \\
\hline Duplicate & J01F72 & $5 / 10 / 04$ & 0.141 & $U$ & 0.22 & 0.057 & $u$ & 0.057 & 0.032 & $U$ & 0.032 & 0.03 & $U$ & 0.03 \\
\hline
\end{tabular}

\begin{tabular}{|c|c|c|c|c|c|c|c|c|c|c|c|c|c|c|}
\hline \multirow{2}{*}{$\begin{array}{c}\text { Sample } \\
\text { Area }\end{array}$} & \multirow{2}{*}{$\begin{array}{c}\text { HEIS } \\
\text { Number }\end{array}$} & \multirow{2}{*}{$\begin{array}{l}\text { Sample } \\
\text { Date }\end{array}$} & \multicolumn{3}{|c|}{ Europium-152 } & \multicolumn{3}{|c|}{ Europium-154 } & \multicolumn{3}{|c|}{ Europium-155 } & \multicolumn{3}{|c|}{ Plutonium-238 } \\
\hline & & & $\mathrm{pCi} / \mathrm{g}$ & Q & MDA & $\mathrm{pCi} / \mathrm{g}$ & $Q$ & MDA & $\mathrm{pCi} / \mathrm{g}$ & Q & MDA & $\mathrm{pCl} / \mathrm{g}$ & a & MDA \\
\hline $\begin{array}{l}\text { Equipment } \\
\text { Blank }\end{array}$ & J01F82 & $4 / 29 / 04$ & 0.048 & $U$ & 0.048 & 0.082 & $\underline{U}$ & 0.082 & 0.056 & U & 0.056 & 0 & $U$ & 0.4 \\
\hline Area 6 & J01F83 & $4 / 29 / 04$ & 0.045 & $U$ & 0.045 & 0.059 & $\mathrm{U}$ & 0.059 & 0.049 & U & 0.049 & 0 & $\mathrm{U}$ & 0.36 \\
\hline Area 5 & J01F84 & $4 / 29 / 04$ & 0.32 & $\mathrm{U}$ & 0.32 & 0.4 & $\mathrm{U}$ & 0.4 & 0.32 & U & 0.32 & 0.062 & $\mathrm{U}$ & 0.48 \\
\hline Area 3 & J01F85 & $5 / 5 / 04$ & 0.078 & $U$ & 0.078 & 0.11 & $\mathrm{U}$ & 0.11 & 0.078 & $\mathrm{U}$ & 0.078 & -0.025 & $\mathrm{U}$ & 0.19 \\
\hline Area 1 & J01F70 & $5 / 5 / 04$ & 0.061 & $\mathrm{U}$ & 0.061 & 0.081 & U & 0.081 & 0.085 & U & 0.085 & 0 & U & 0.25 \\
\hline Area 2 & J01F71 & $5 / 10 / 04$ & 0.082 & $U$ & 0.082 & 0.094 & $U$ & 0.094 & 0.075 & U & 0.075 & 0 & $\mathrm{U}$ & 0.24 \\
\hline Duplicate & J01F72 & $5 / 10 / 04$ & 0.094 & U & 0.094 & 0.097 & $U$ & 0.097 & 0.086 & $\mathrm{U}$ & 0.086 & 0.076 & $U$ & 0.29 \\
\hline
\end{tabular}

\begin{tabular}{|c|c|c|c|c|c|c|c|c|c|c|c|c|c|c|}
\hline \multirow{2}{*}{$\begin{array}{c}\text { Sample } \\
\text { Area }\end{array}$} & \multirow{2}{*}{$\begin{array}{c}\text { HEIS } \\
\text { Number }\end{array}$} & \multirow{2}{*}{$\begin{array}{c}\text { Sample } \\
\text { Date }\end{array}$} & \multicolumn{3}{|c|}{ Plutonium-239/240 } & \multicolumn{3}{|c|}{ Potassium -40} & \multicolumn{3}{|c|}{ Padium-226 } & \multicolumn{3}{|c|}{ Radium-228 } \\
\hline & & & $\mathrm{pCi} / \mathrm{g}$ & $Q$ & MDA & $\mathrm{pCl} / \mathrm{g}$ & a & MDA & $\mathrm{pCi} / \mathrm{g}$ & Q & MDA & $\mathrm{pCi} / \mathrm{g}$ & Q & MDA \\
\hline $\begin{array}{l}\text { Equipment } \\
\text { Blank }\end{array}$ & J01F82 & $4 / 29 / 04$ & 0.103 & $\mathrm{U}$ & 0.4 & 4.84 & & 0.31 & 0.14 & & 0.045 & 0.223 & & 0.11 \\
\hline Area 6 & J01F83 & $4 / 29 / 04$ & 0.234 & $\mathrm{U}$ & 0.36 & 6.91 & & 0.18 & 0.256 & & 0.039 & 0.44 & & 0.083 \\
\hline Area 5 & J01F84 & $4 / 29 / 04$ & 0.249 & $\mathrm{U}$ & 0.48 & 5.4 & $\mathrm{U}$ & 5.4 & 0.3 & $U$ & 0.3 & 0.76 & $\mathrm{U}$ & 0.76 \\
\hline Area 3 & J01F85 & $5 / 5 / 04$ & 0 & $\mathrm{U}$ & 0.19 & 10.5 & & 0.34 & 0.46 & & 0.059 & 0.542 & & 0.16 \\
\hline Area 1 & J01F70 & $5 / 5 / 04$ & 0.097 & U & 0.25 & 11.7 & & 0.28 & 0.589 & & 0.055 & 0.814 & & 0.11 \\
\hline Area 2 & J01F71 & $5 / 10 / 04$ & 0.816 & & 0.24 & 9.74 & & 0.25 & 0.355 & & 0.05 & 0.653 & & 0.12 \\
\hline Duplicate & J01F72 & $5 / 10 / 04$ & 0.57 & & 0.29 & 10.7 & & 0.24 & 0.356 & & 0.067 & 0.761 & & 0.14 \\
\hline
\end{tabular}

\begin{tabular}{|c|c|c|c|c|c|c|c|c|c|c|c|c|c|c|}
\hline \multirow{2}{*}{$\begin{array}{c}\text { Sample } \\
\text { Area }\end{array}$} & \multirow{2}{*}{$\begin{array}{c}\text { HEIS } \\
\text { Number }\end{array}$} & \multirow{2}{*}{$\begin{array}{c}\text { Sample } \\
\text { Date }\end{array}$} & \multicolumn{3}{|c|}{ Thorium-228 GEA } & \multicolumn{3}{|c|}{ Thorium-232 GEA } & \multicolumn{3}{|c|}{ Uranium-235 GEA } & \multicolumn{3}{|c|}{ Uranium-238 GEA } \\
\hline & & & $\mathrm{pCi} / \mathrm{g}$ & $Q$ & MDA & $\mathrm{pCi} / \mathrm{g}$ & Q & MDA & $\mathrm{pCi} / \mathrm{g}$ & Q & MDA & $\mathrm{pCi} / \mathrm{g}$ & Q & MDA \\
\hline $\begin{array}{l}\text { Equipment } \\
\text { Blank }\end{array}$ & J01F82 & $4 / 29 / 04$ & 0.187 & & 0.025 & 0.223 & & 0.11 & 0.08 & $\mathrm{U}$ & 0.08 & 3.2 & U & 3.2 \\
\hline Area 6 & J01F83 & $4 / 29 / 04$ & 0.397 & & 0.022 & 0.44 & & 0.083 & 0.069 & $\mathrm{U}$ & 0.069 & 2.6 & $U$ & 2.6 \\
\hline Area 5 & J01F84 & $4 / 29 / 04$ & 0.36 & $U$ & 0.36 & 0.76 & $\mathrm{U}$ & 0.76 & 0.47 & $\mathrm{U}$ & 0.47 & 18 & $U$ & 18 \\
\hline Area 3 & J01F85 & $5 / 5 / 04$ & 0.52 & & 0.034 & 0.542 & & 0.16 & 0.11 & $U$ & 0.11 & 3.5 & $U$ & 3.5 \\
\hline Area 1 & J01F70 & $5 / 5 / 04$ & 0.626 & & 0.034 & 0.814 & & 0.11 & 0.11 & $U$ & 0.11 & 3.3 & $U$ & 3.3 \\
\hline Area 2 & J01F71 & $5 / 10 / 04$ & 0.716 & & 0.047 & 0.653 & & 0.12 & 0.12 & U & 0.12 & 2.9 & $u$ & 2.9 \\
\hline Duplicate & J01F72 & $5 / 10 / 04$ & 0.639 & & 0.054 & 0.761 & & 0.14 & 0.13 & $U$ & 0.13 & 3.4 & U & 3.4 \\
\hline
\end{tabular}

$\mathrm{GEA}=$ gamma energy analysis

HEIS = Hanford Environmental Information System

$J=$ estimate

$M D A=$ minimum detectable activity

$\mathrm{PCB}=$ polychlorinated biphenyl

$\mathrm{PQL}=$ practical quantitation limit

$\mathrm{Q}=$ qualifier

SVOA = semivolatile organic analyses

$\mathrm{U}=$ undetected.

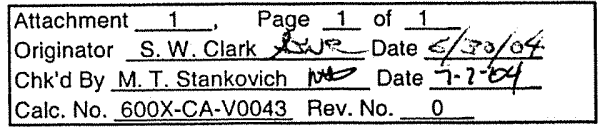




\section{ATTACHMENT 2}

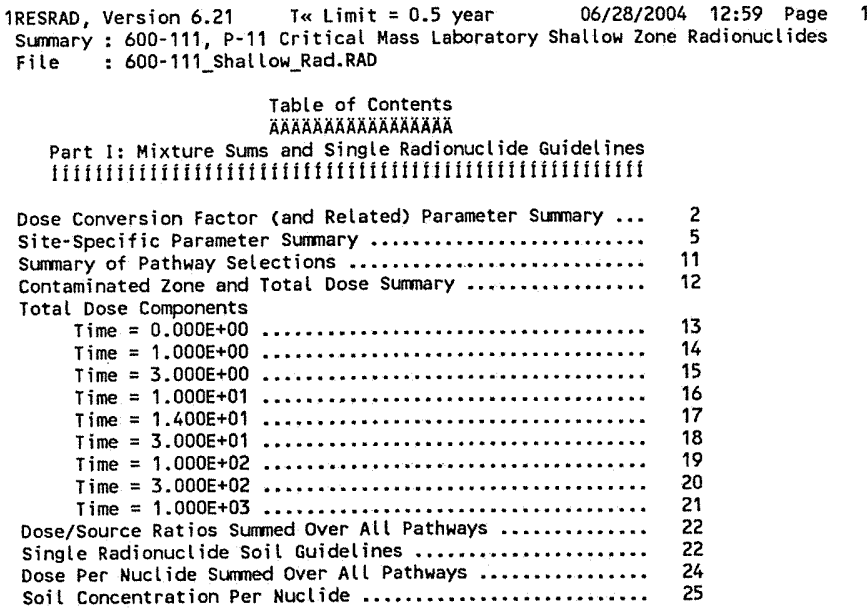




\section{ATTACHMENT 2}

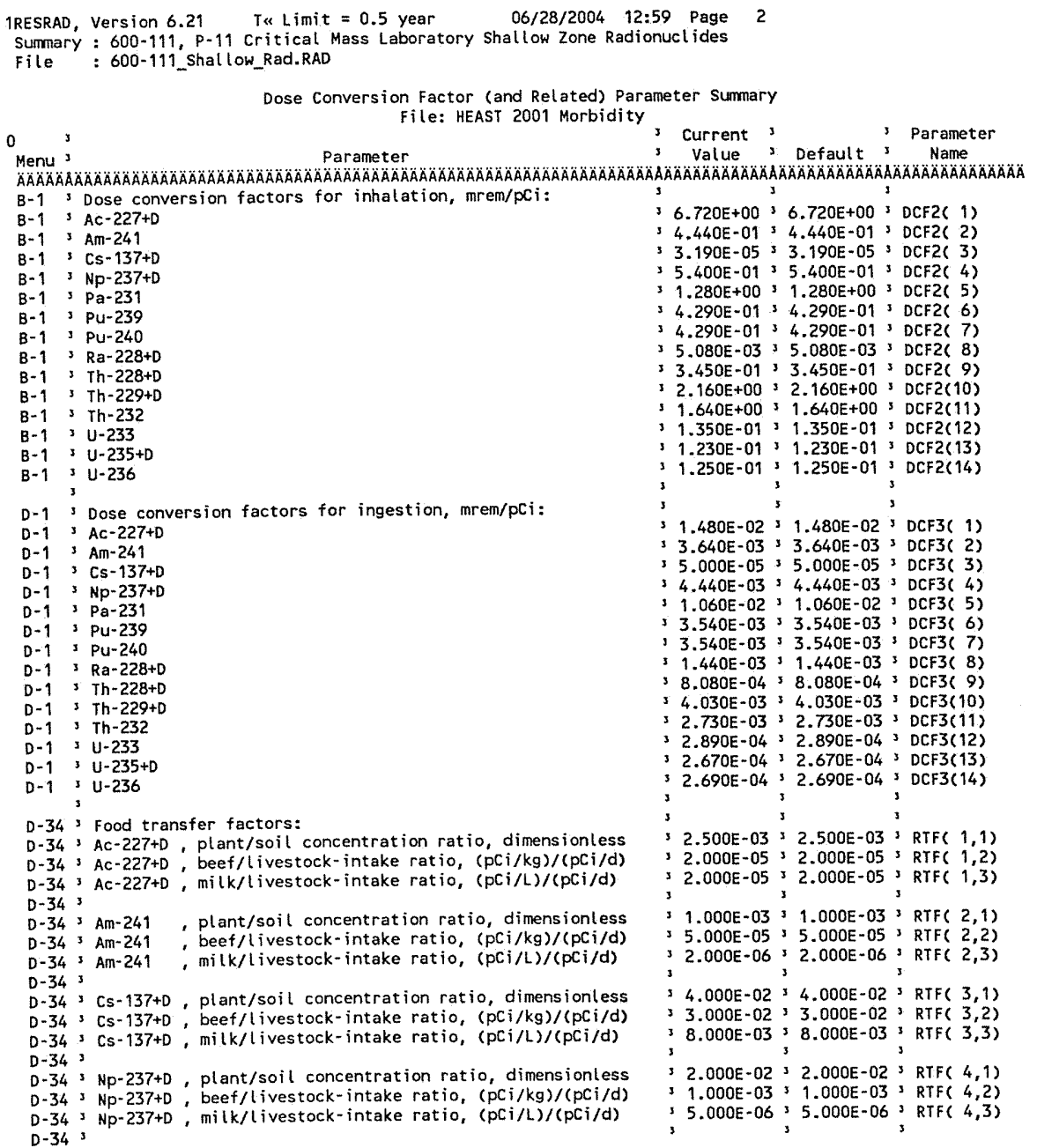

D-34 3

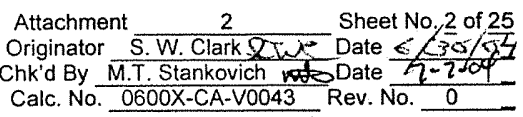




\section{ATTACHMENT 2}

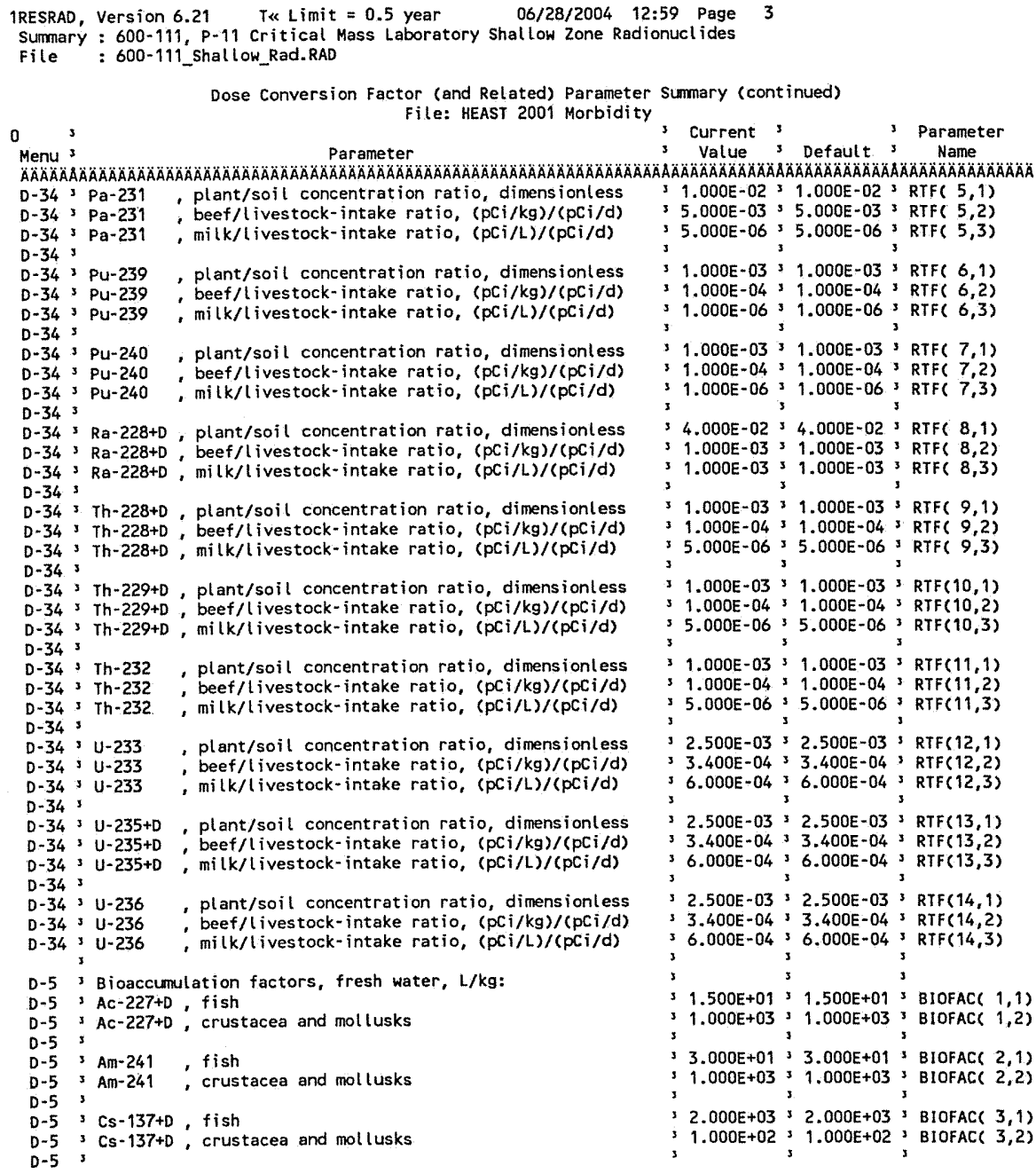


ATTACHMENT 2

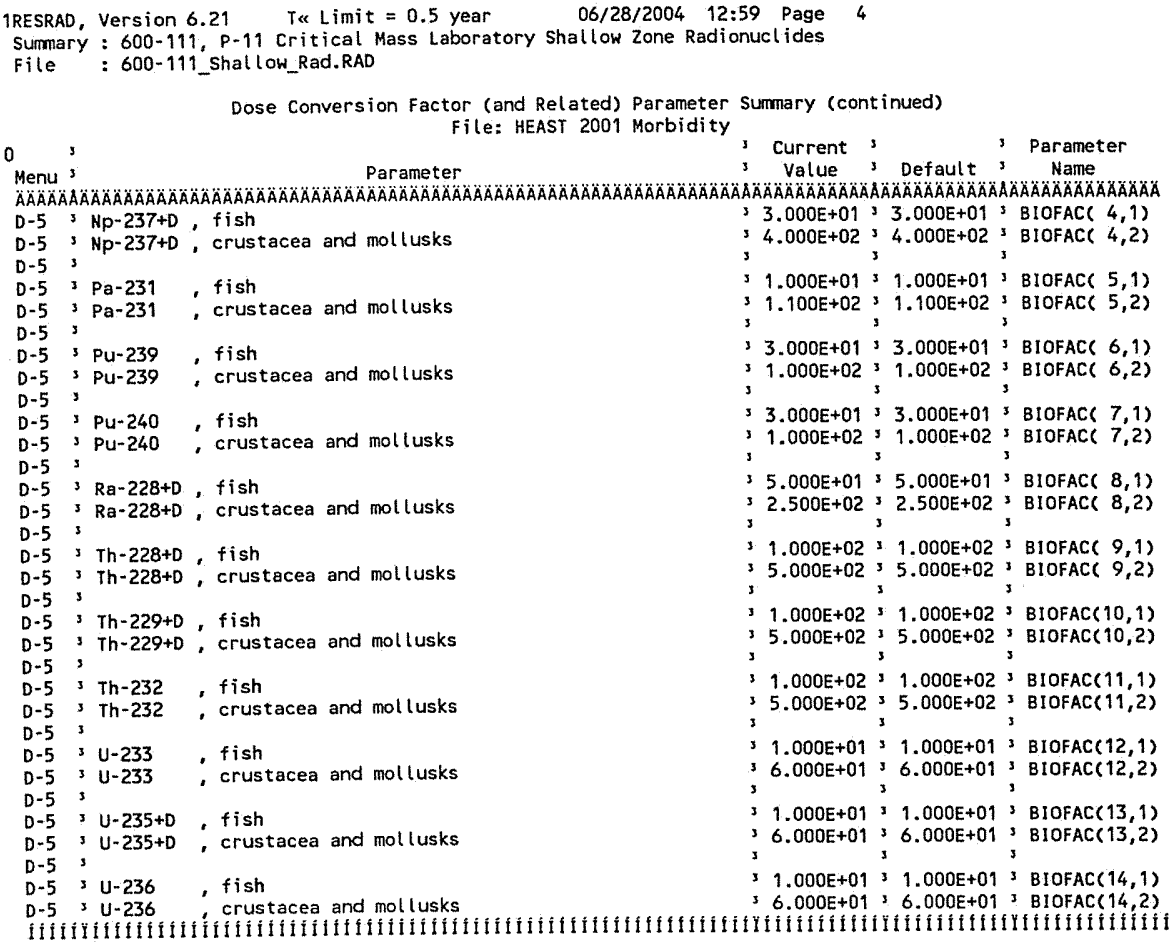

\begin{tabular}{ll} 
Attachment $\frac{2}{1}$ & Sheet No. 4 of 25 \\
Originator S.W. Clark & Date \\
Chk'd By M.T. Stankovich & Date \\
Calc. No. 0600 X-CA-V0043 Rev. No. 0 \\
\hline
\end{tabular}




\section{ATTACHMENT 2}

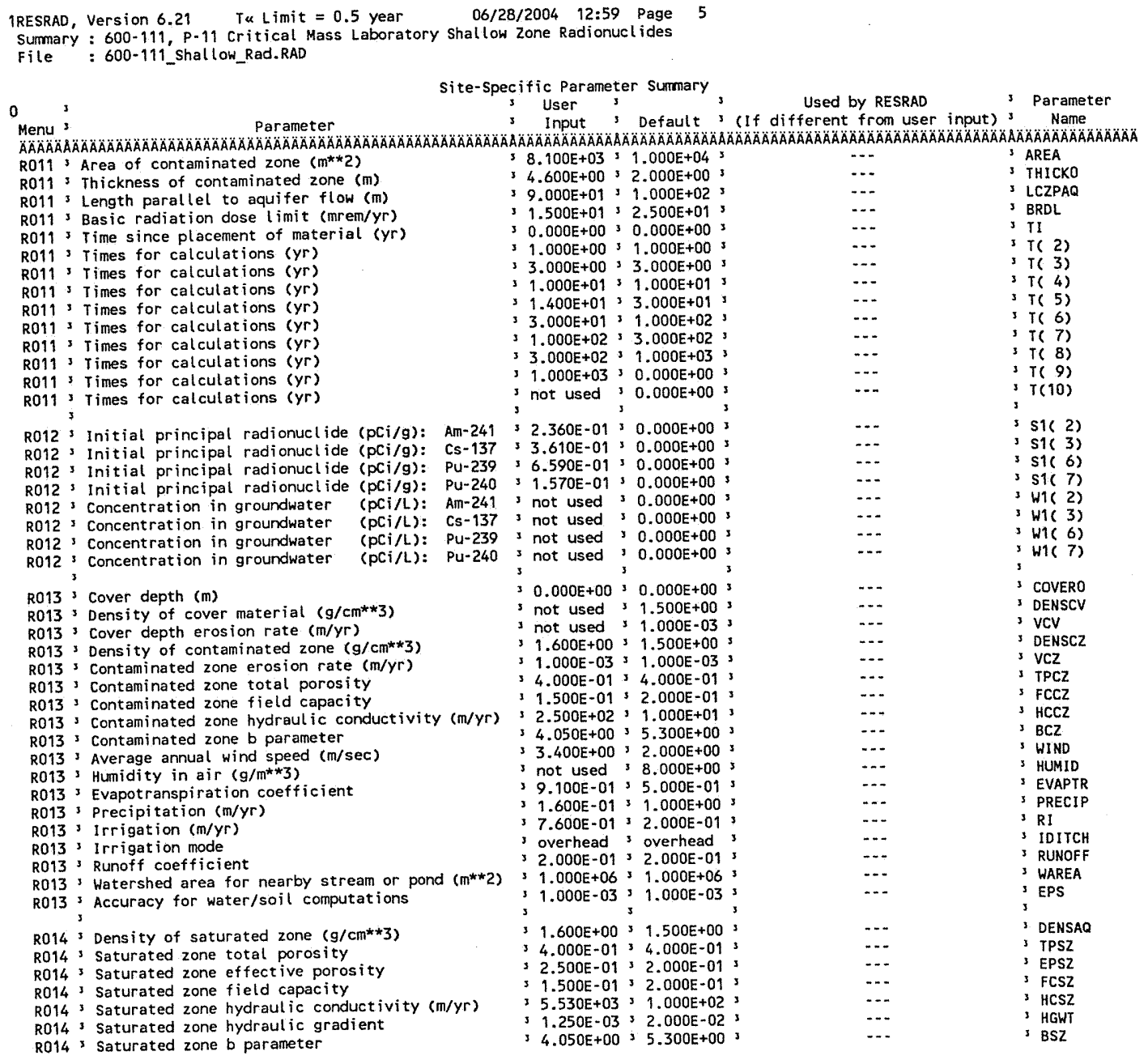

\begin{tabular}{l} 
Attachment $\frac{2}{\text { S.W. Clark }}$ Sheet No. $\underline{5}$ of 25 \\
Originator \\
Chk'd By M.T. Stankovich \\
Date \\
Calc. No. 0600X-CA-V0043 Rev. No. 0 \\
\hline
\end{tabular}




\section{ATTACHMENT 2}

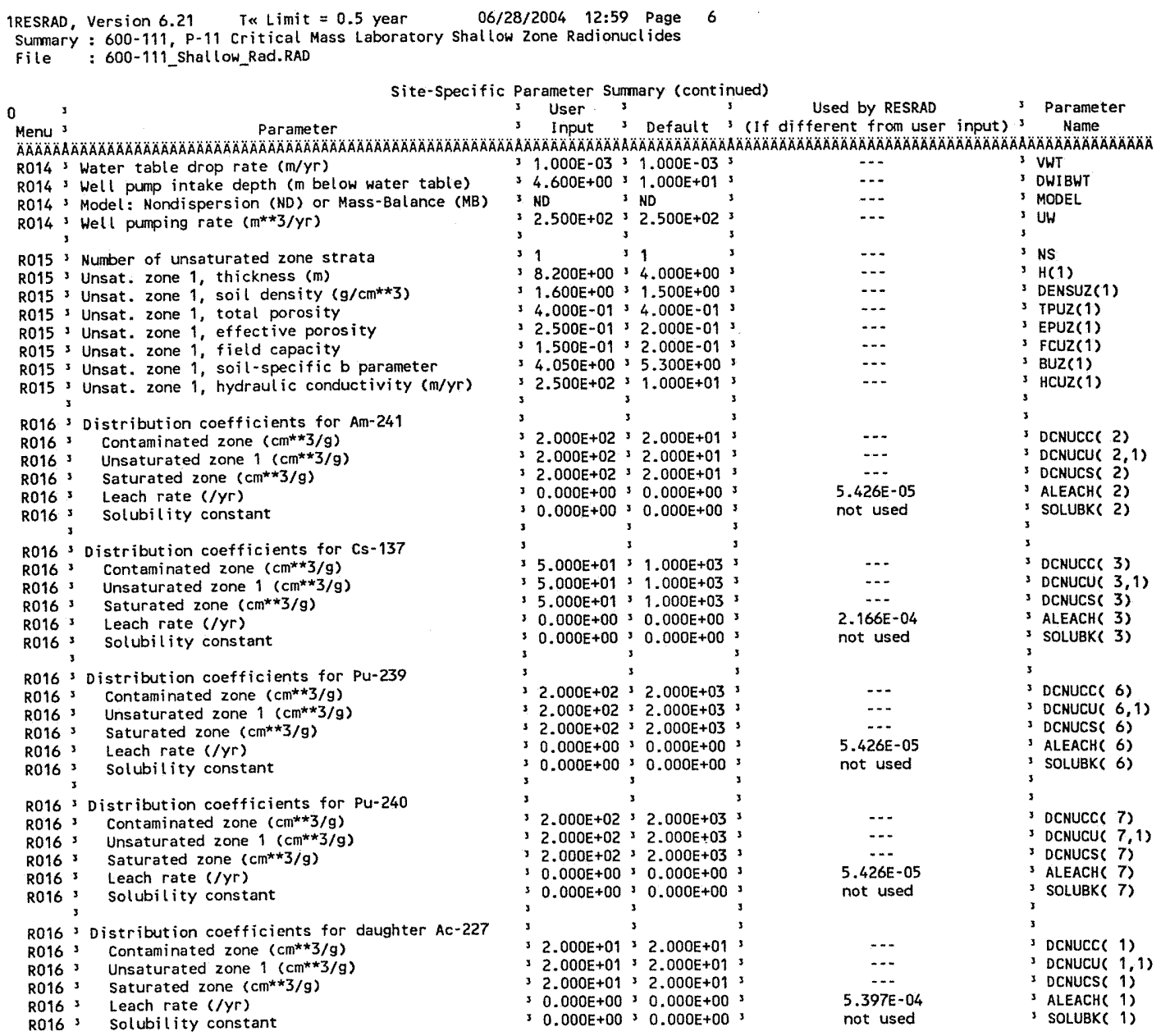

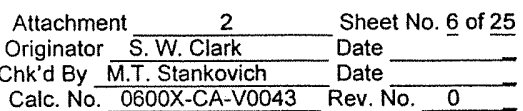




\section{ATTACHMENT 2}

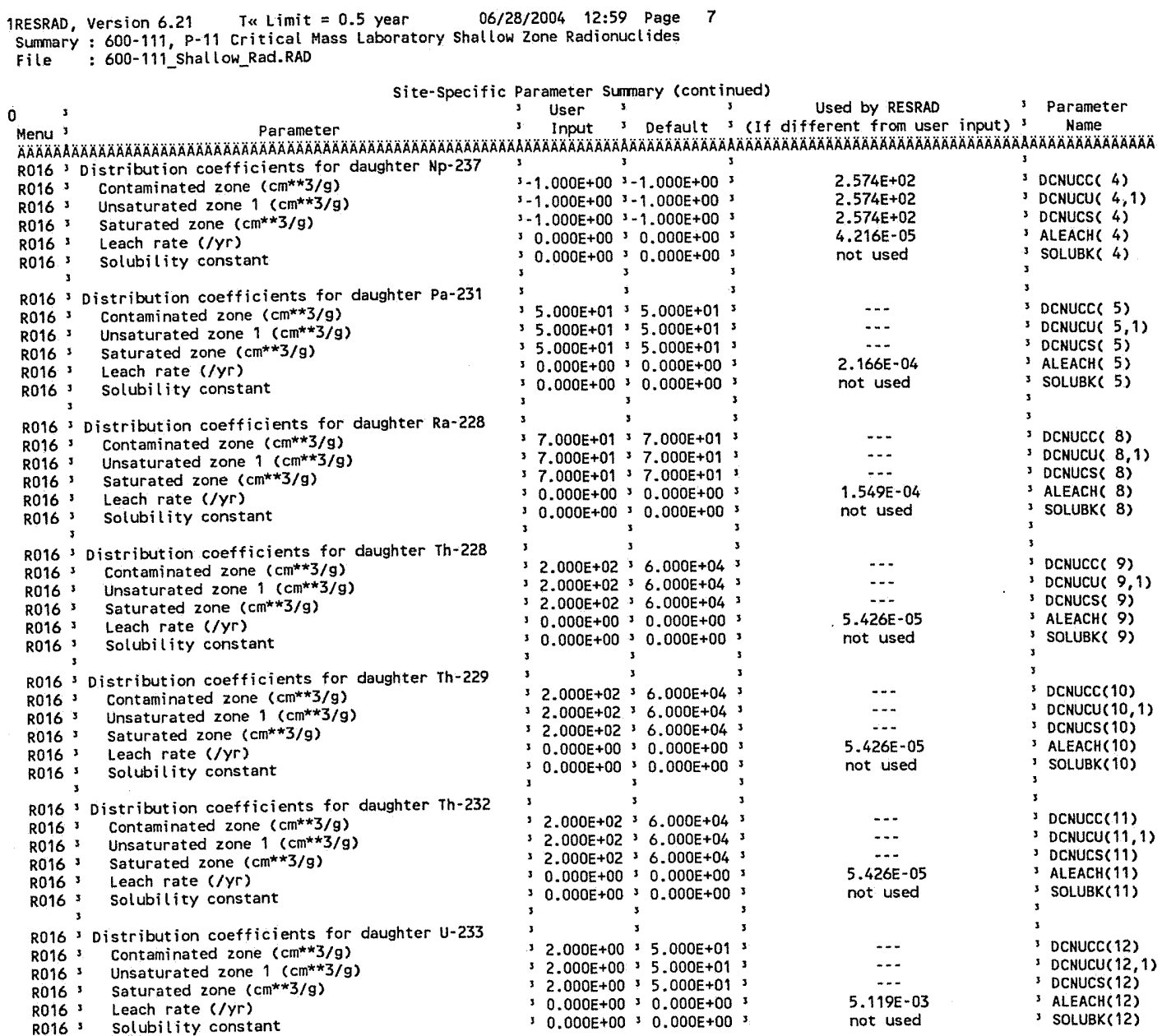

Attachment $\frac{2}{\text { S.W. Clark }}$ Date
Originator $\frac{\text { So. } 7 \text { of } 25}{\text { Date }}$
Chk'd By M.T. Stankovich
Calc. No. 0600X-CA-V0043 Rev. No. 0




\section{ATTACHMENT 2}

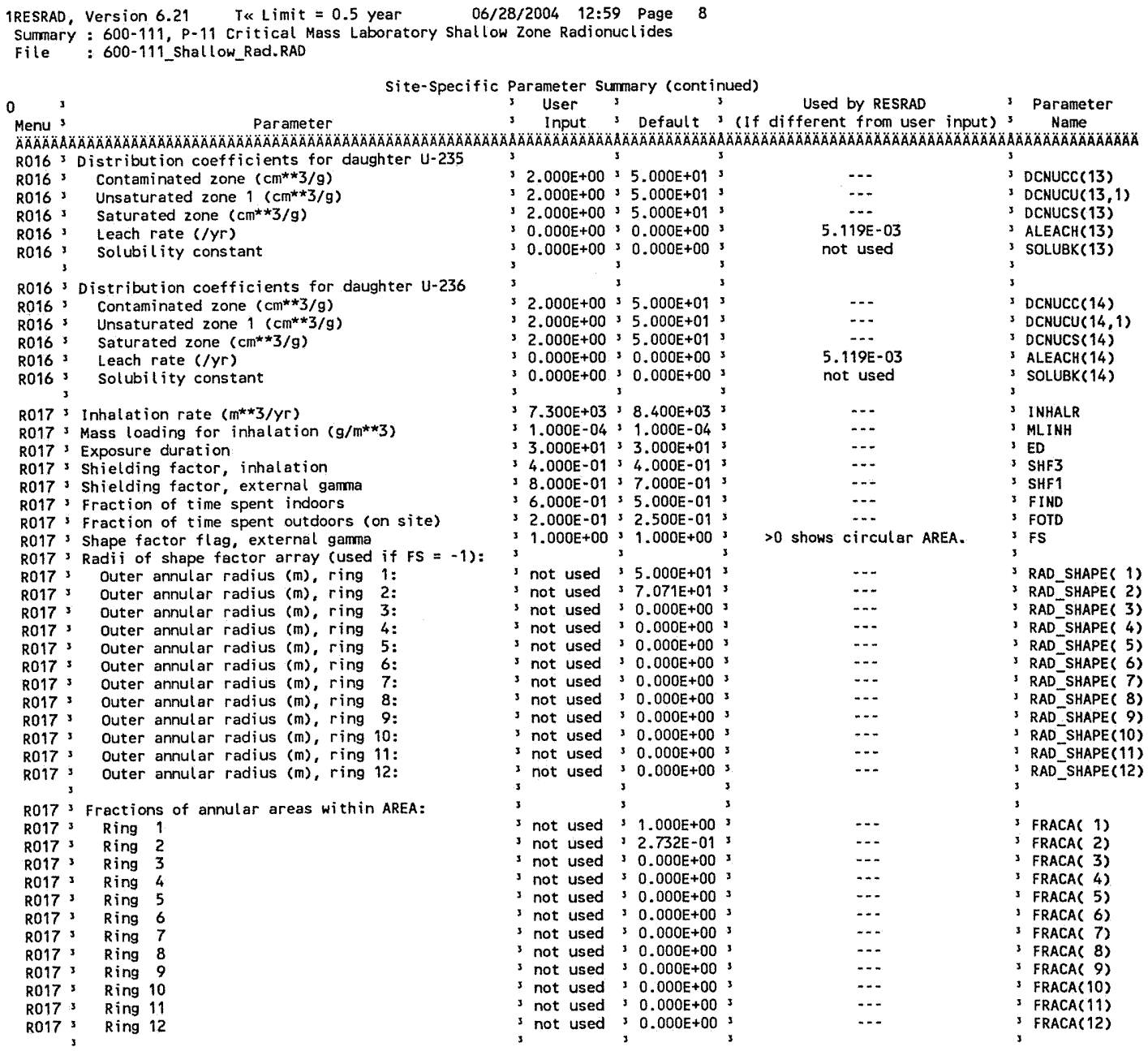

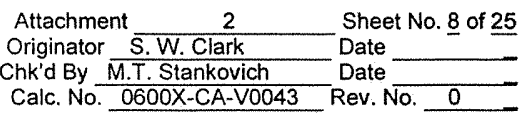




\section{ATTACHMENT 2}

IRESRAD, Version $6.21 \quad T \ll L$ Limit $=0.5$ year $06 / 28 / 2004 \quad 12: 59$ Page 9 Sumary : 600-111, P-11 Critical Mass Laboratory Shallow Zone Radionuclides file : 600-111_shallow_Rad.RAD

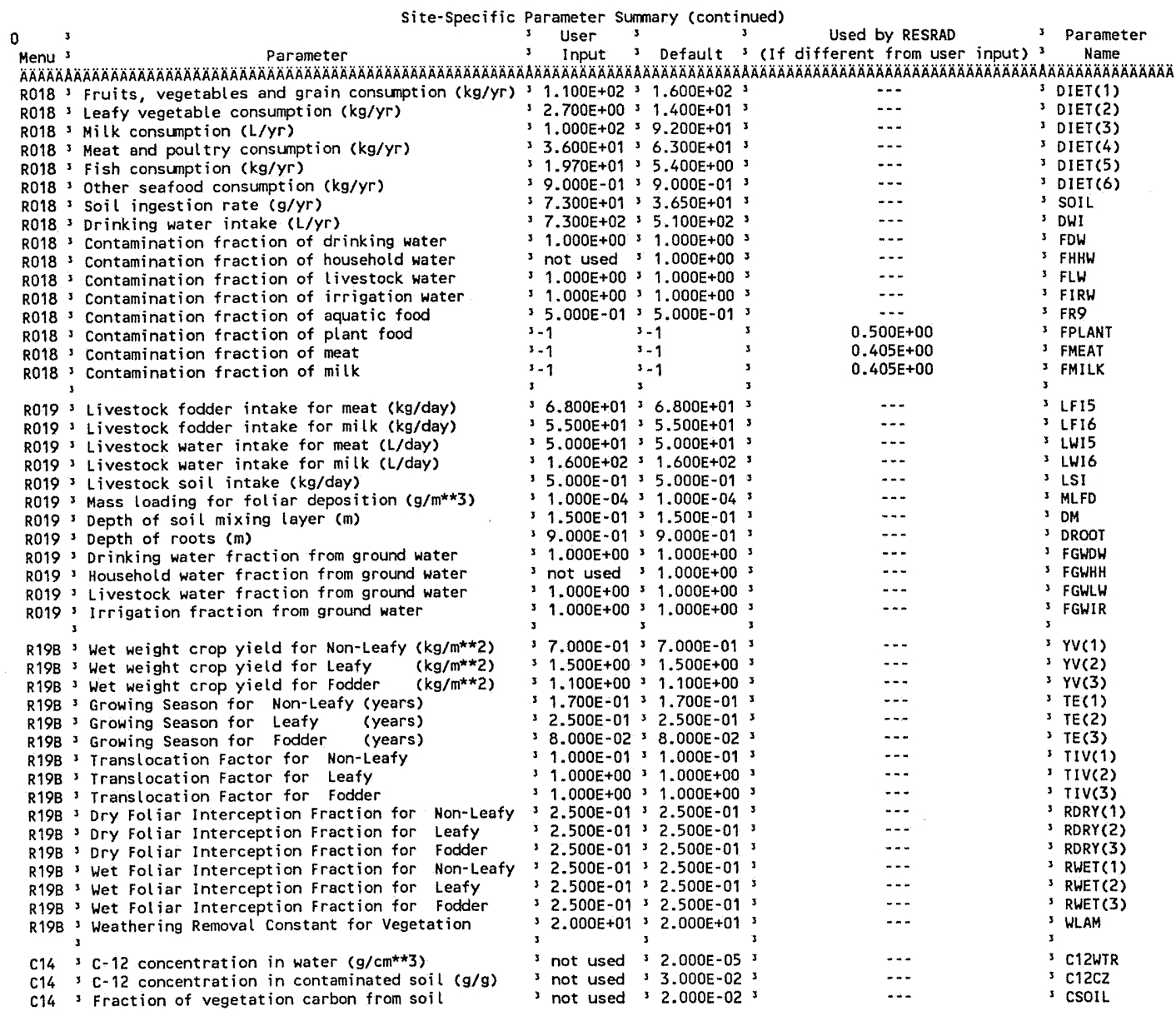

$\begin{array}{ll}\text { Attachment } \frac{2}{\text { S.W. Clark }} & \text { Sheet No. } \underline{9} \text { of } 25 \\ \text { Originator } & \text { Date } \\ \text { Chk'd By M.T. Stankovich } & \text { Date } \\ \text { Calc. No. 0600X-CA-V0043 Rev. No. } & 0\end{array}$




\section{ATTACHMENT 2}

1RESRAD, Version $6.21 \quad T \ll$ Limit $=0.5$ year $\quad 06 / 28 / 2004 \quad 12: 59$ Page 10 Sumary : 600-111, p-11 Critical Mass Laboratory Shallow Zone Radionuclides file: 600-111_shallow_Rad.RAD

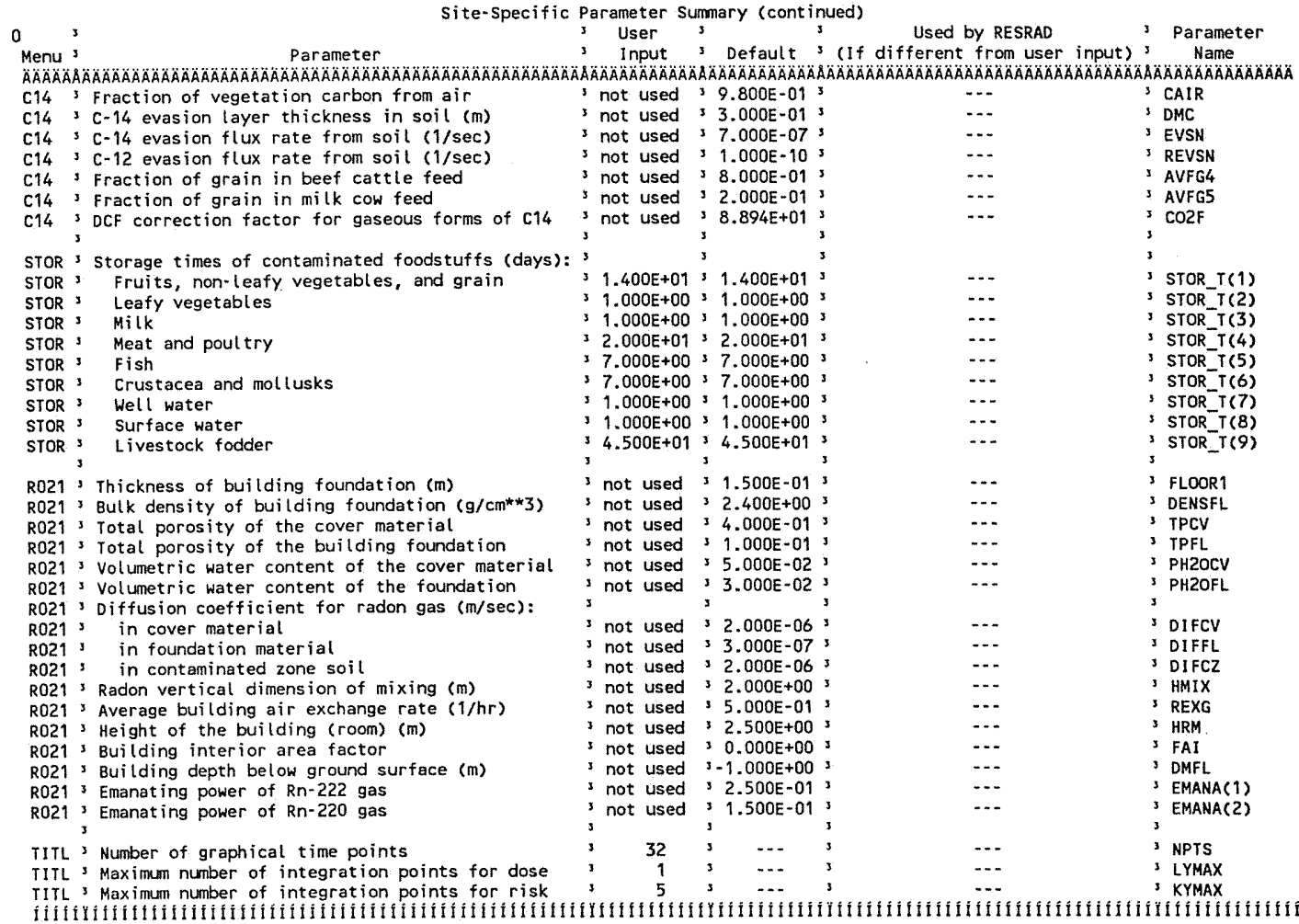

\begin{tabular}{|c|c|}
\hline tachment & Sheet No. 10 of 25 \\
\hline Originator S.W. Clark & Date \\
\hline M.T. Stankovich & Date \\
\hline
\end{tabular}


ATTACHMENT 2

1RESRAD, Version 6.21 T\& Limit $=0.5$ year $\quad 06 / 28 / 2004 \quad 12: 59$ Page 11 Sumary : 600-111, P-11 Critical Mass Laboratory Shallow Zone Radionuclides

File: $600-111$ Shal low_Rad.RAD

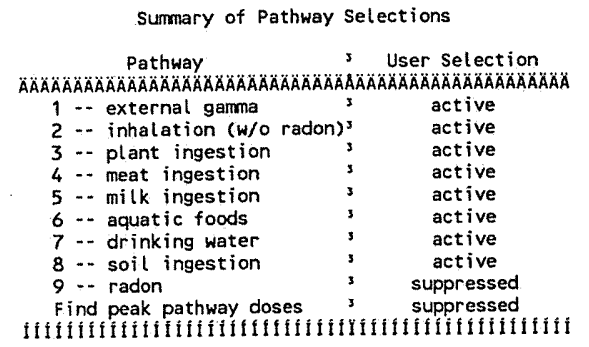

Attachment $\frac{2}{2}$ Sheet No. 11 of 25
Originator S.W. Clark
Chk'd By M.T. Stankovich
Date
Calc. No. O600X-CA-V0043




\section{ATTACHMENT 2}

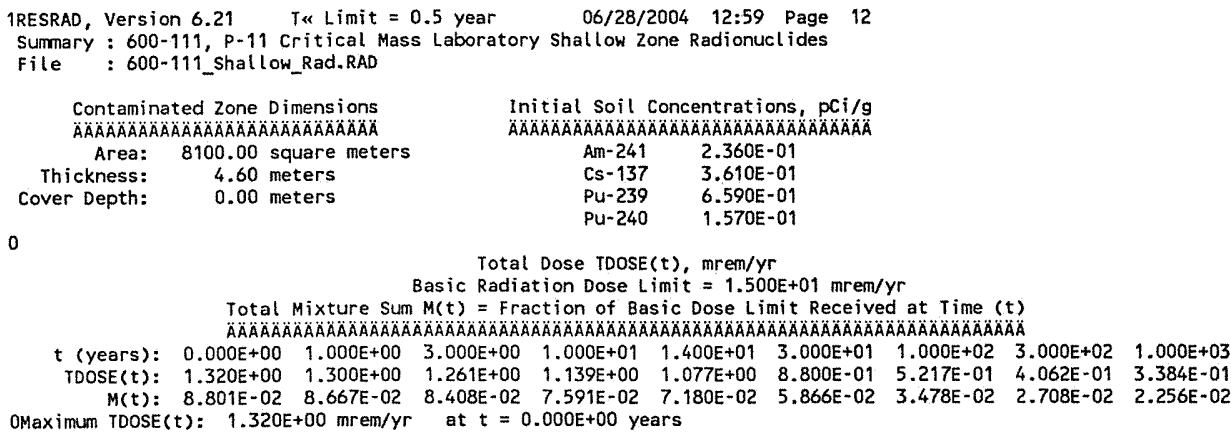




\section{ATTACHMENT 2}

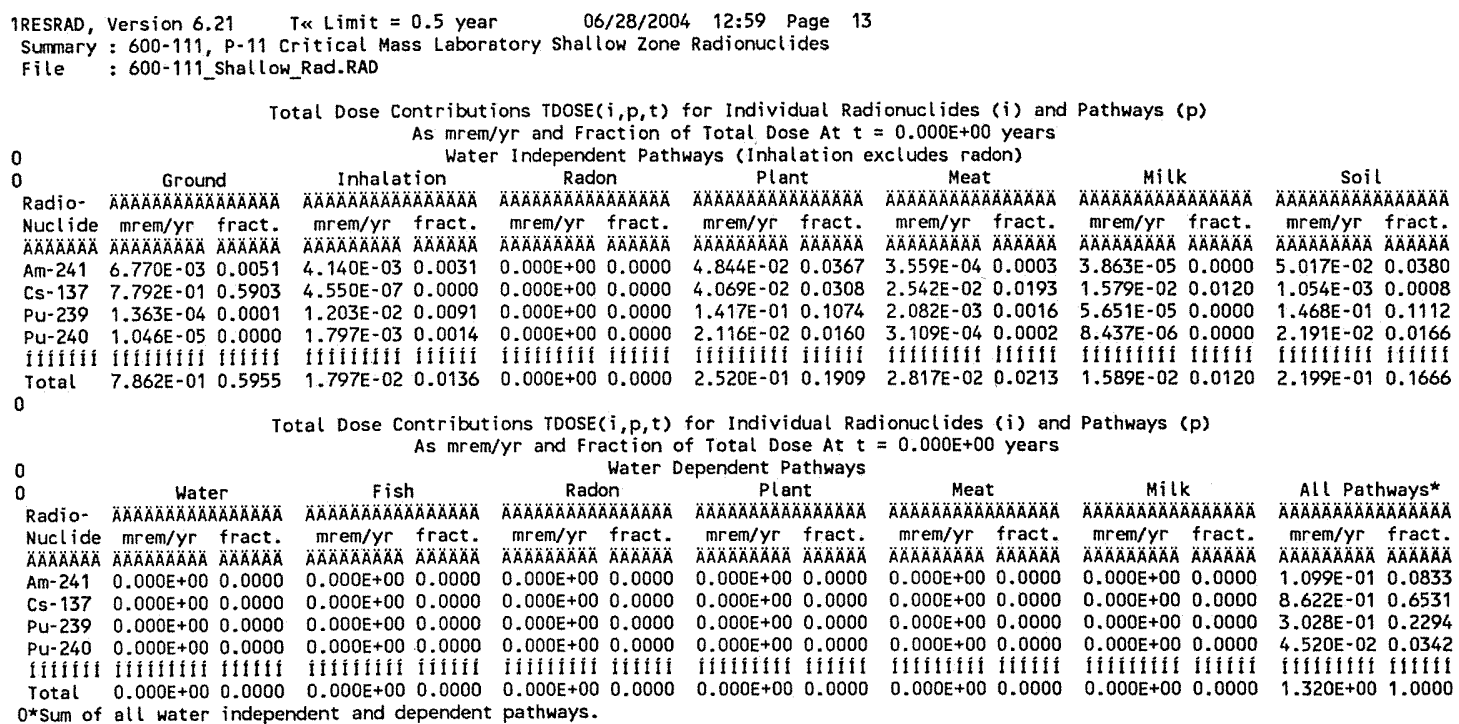




\section{ATTACHMENT 2}

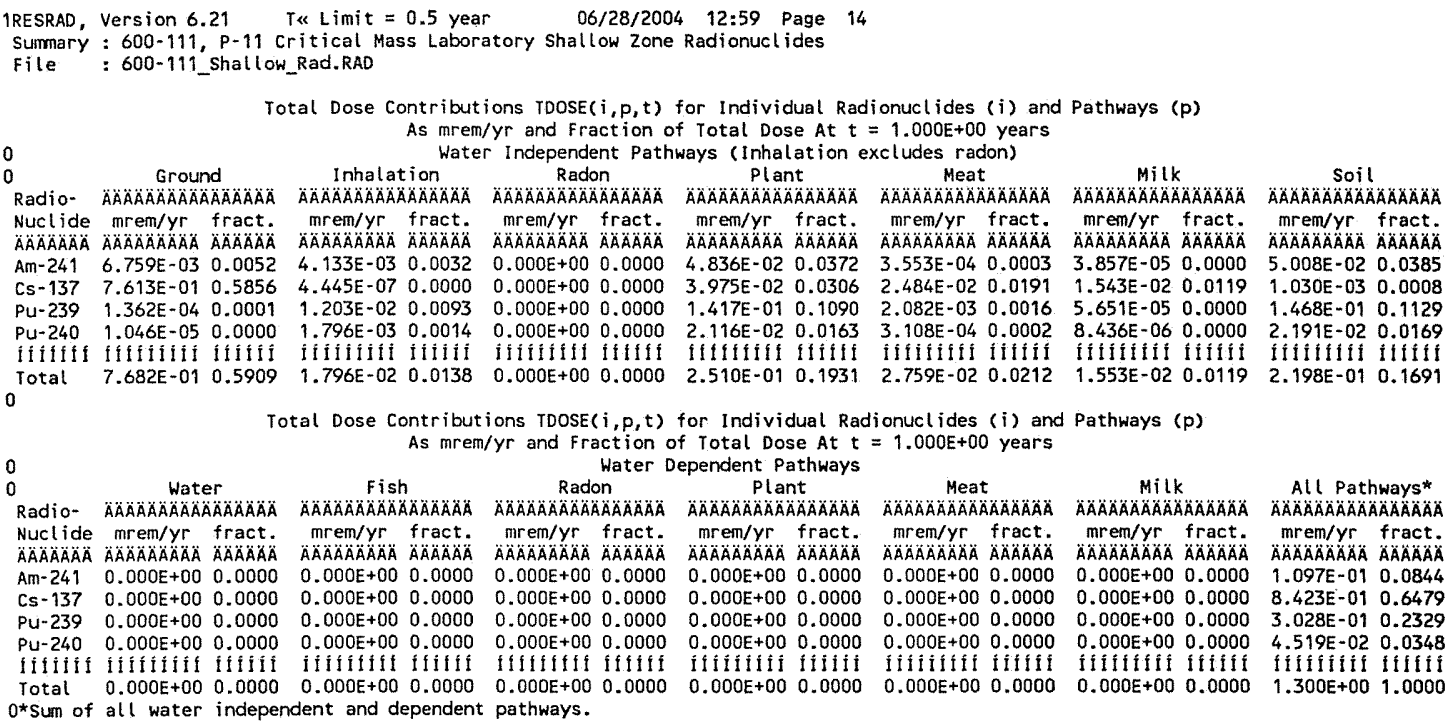




\section{ATTACHMENT 2}

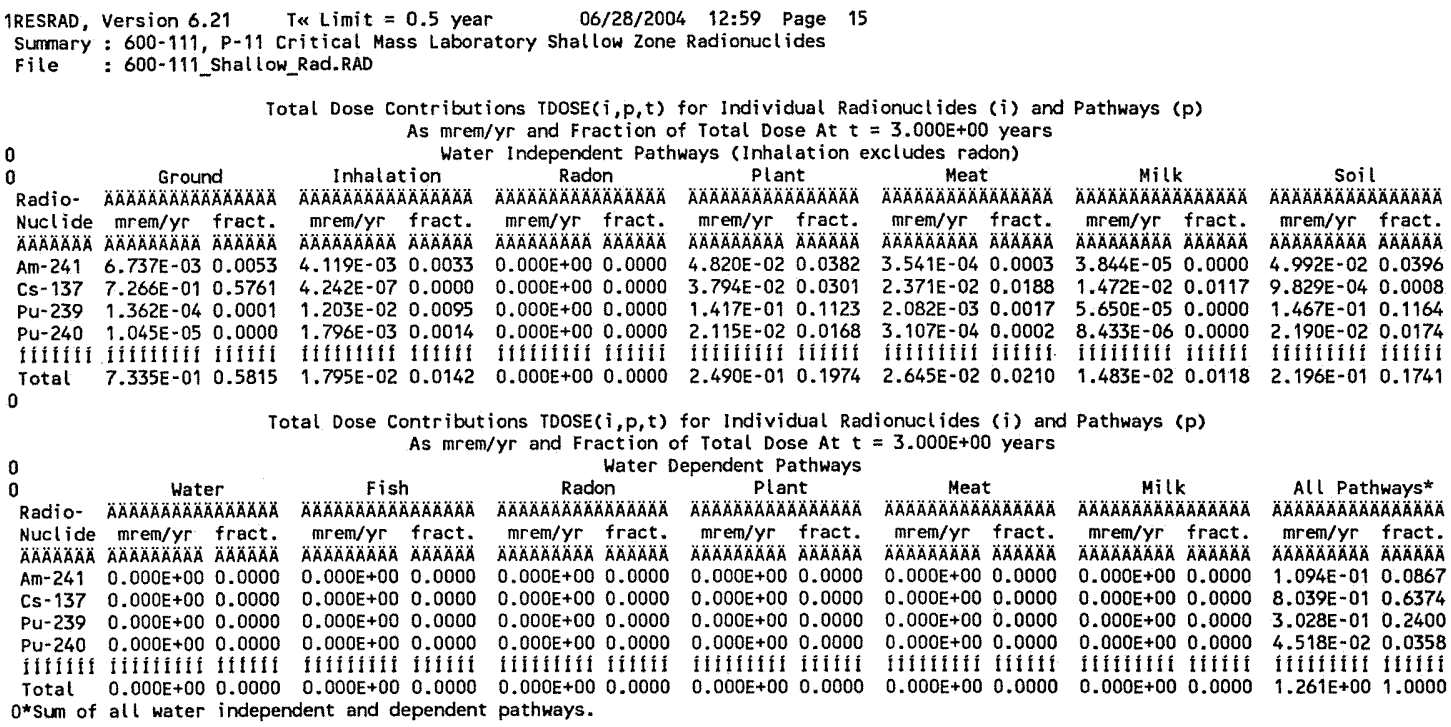




\section{ATT ACHMENT 2}

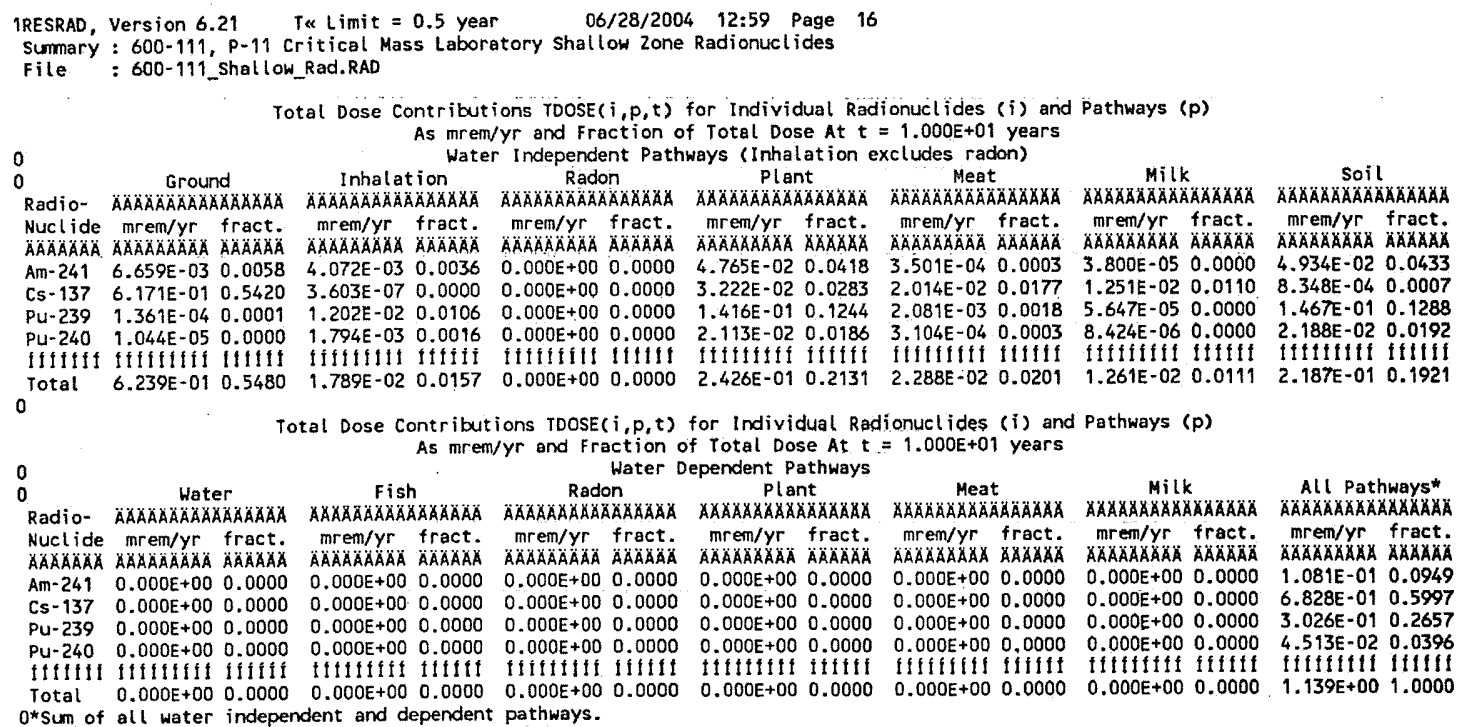


ATTACHMENT 2

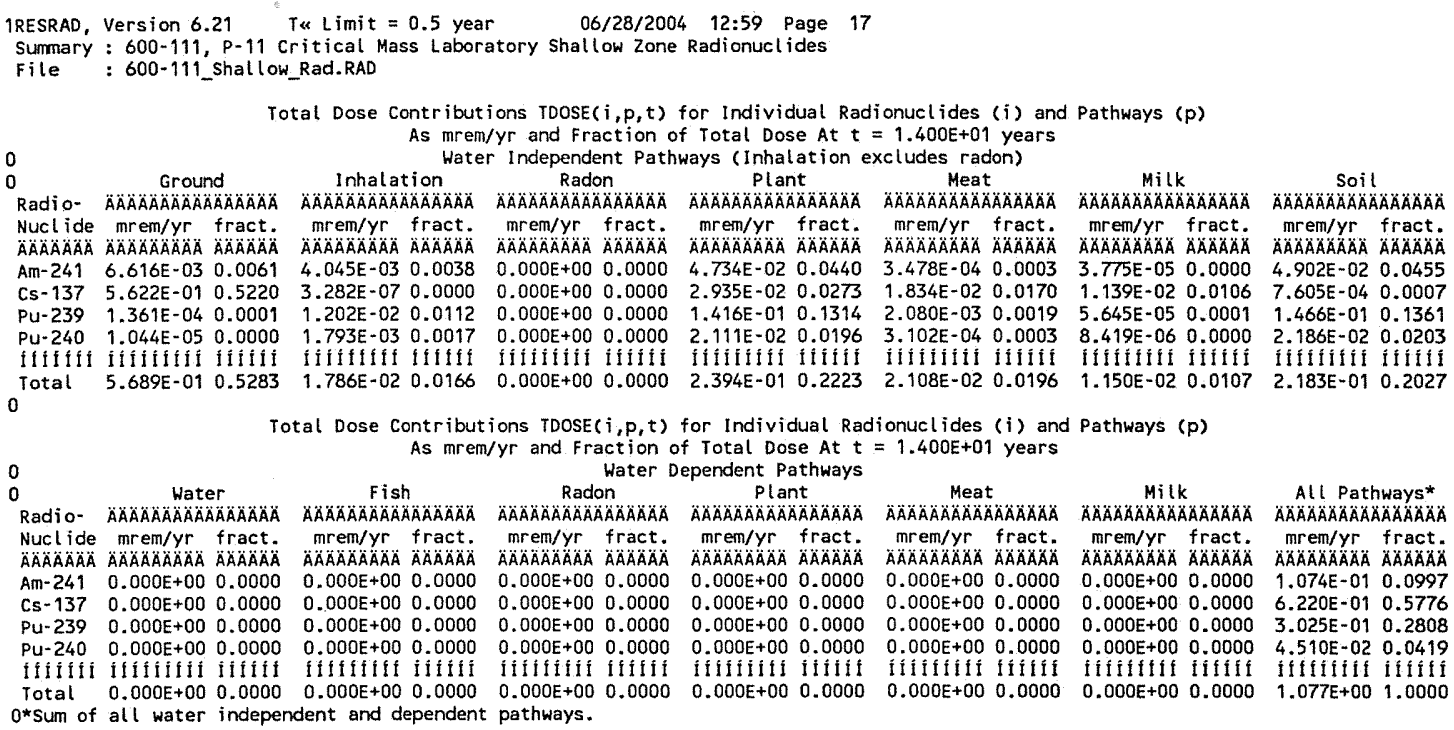




\section{ATTACHMENT 2}

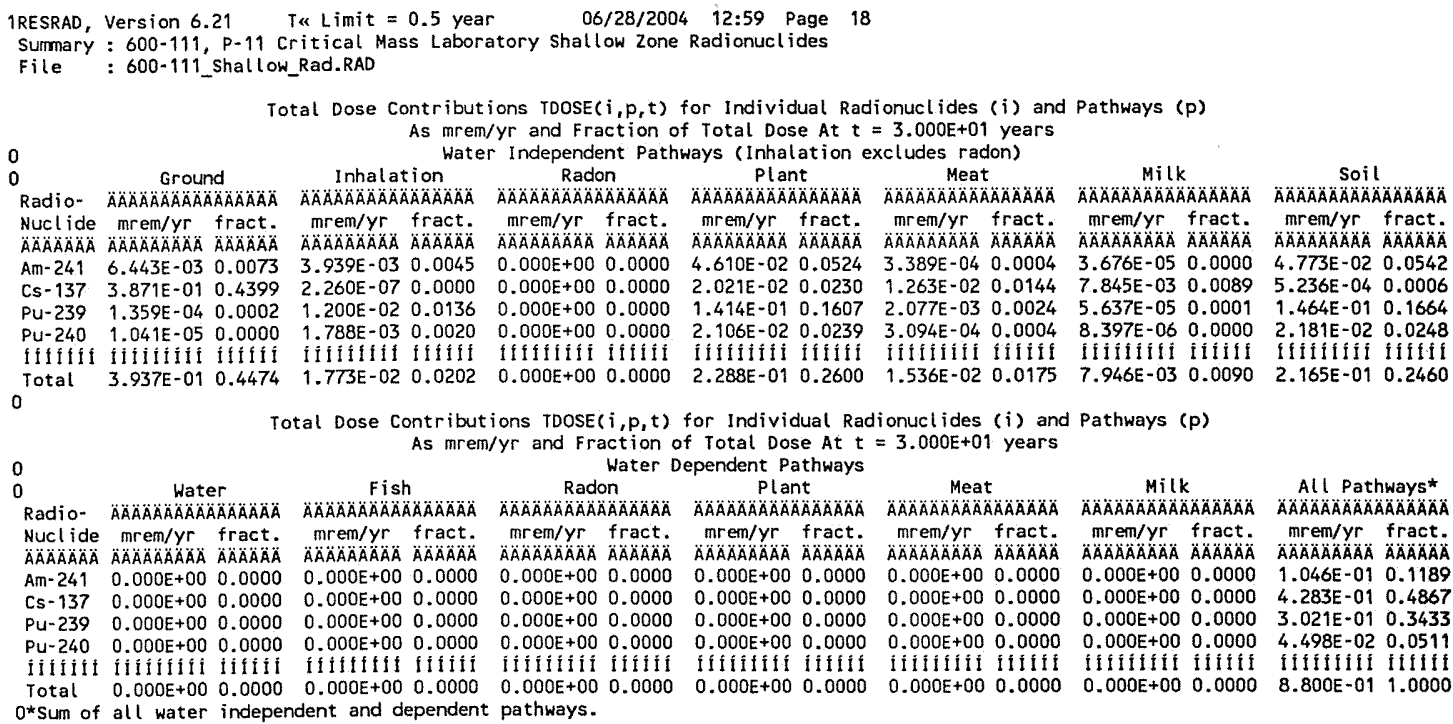




\section{ATTACHMENT 2}

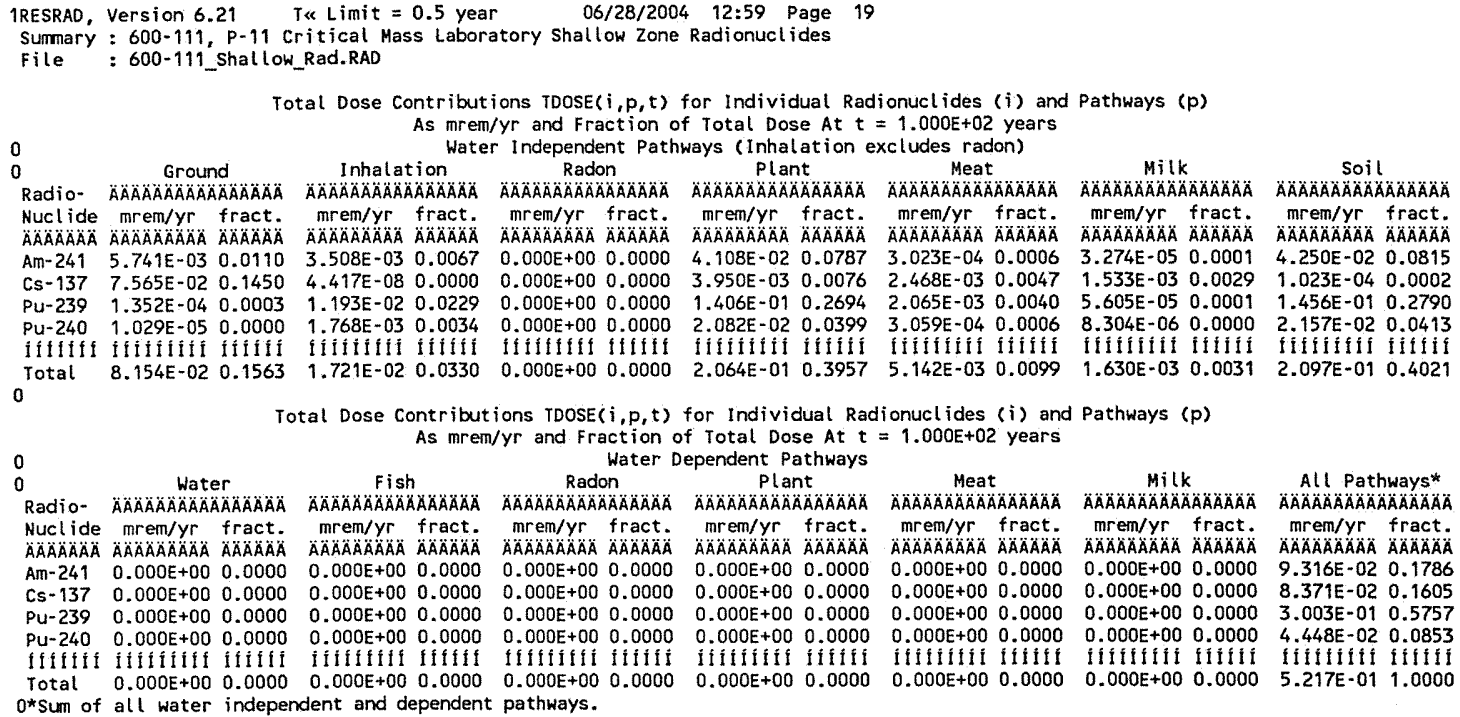




\section{ATTACHMENT 2}

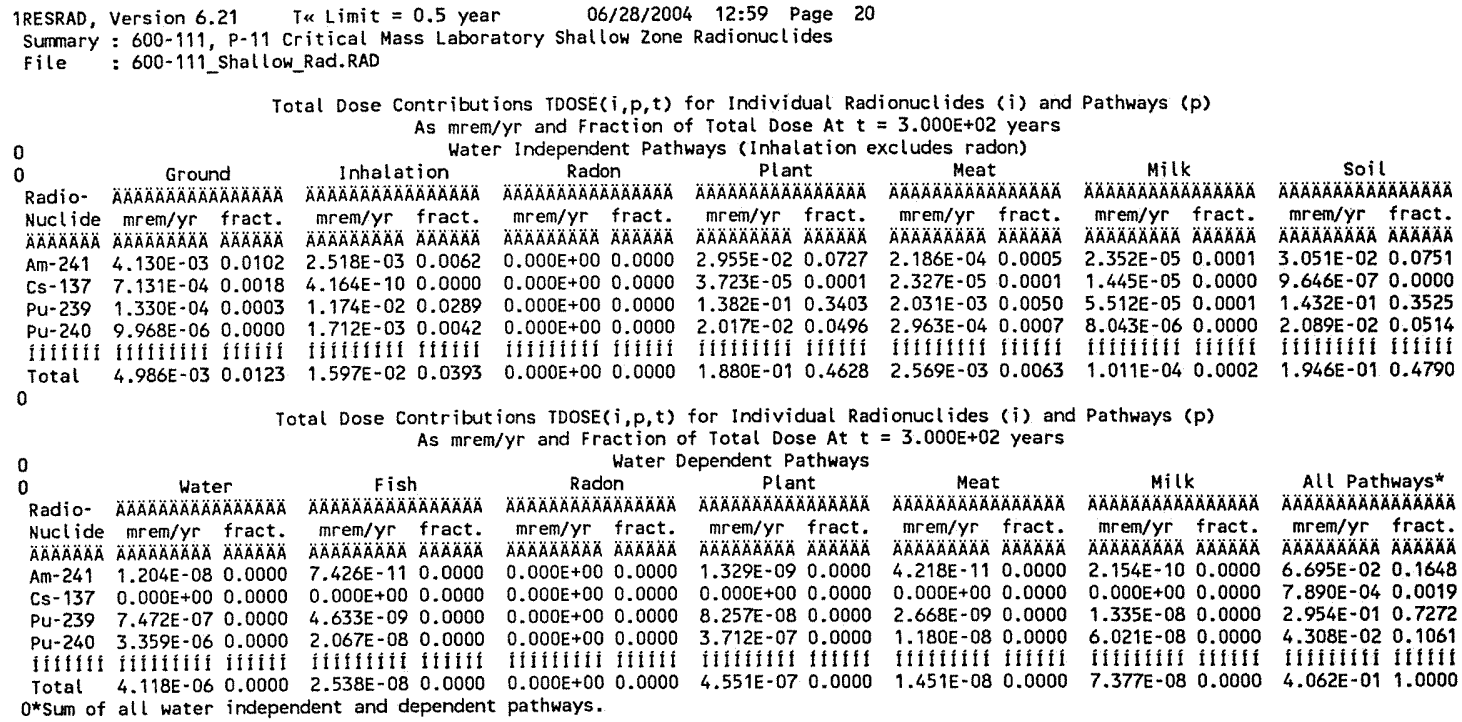




\section{ATTACHMENT 2}

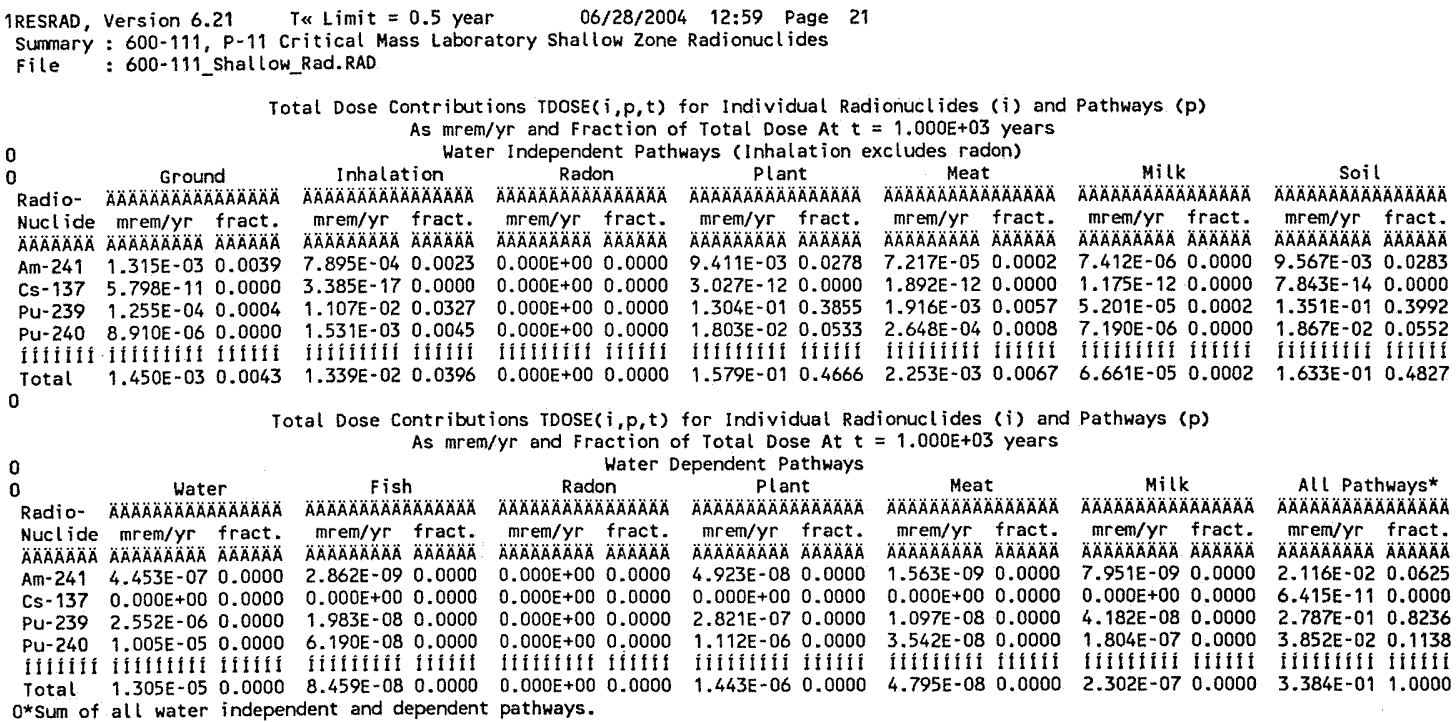




\section{ATTACHMENT 2}

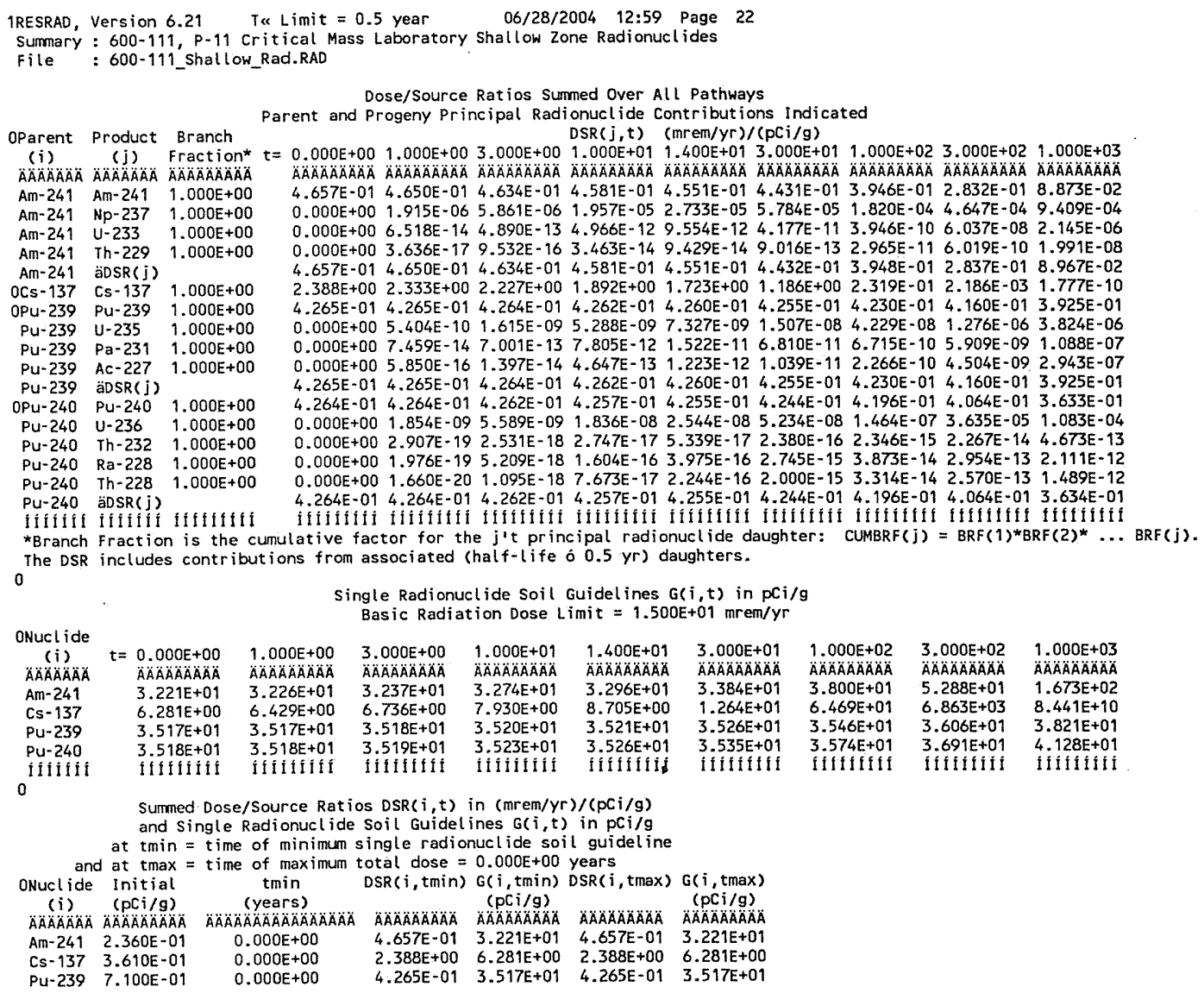

\begin{tabular}{l} 
Attachment $\frac{2}{c}$ Sheet No. 22 of 25 \\
Originator S.W. Clark \\
Chk'd By M.T.Stankovich \\
Cate \\
Calc. No. 0600X-CA-V0043 Rev. No. 0 \\
\hline
\end{tabular}




\section{ATTACHMENT 2}

IRESRAD, Version 6.21 T\& Limit $=0.5$ year $06 / 28 / 2004 \quad 12: 59$ Page 23 Summary : $600-111, \mathrm{p}-11$ critical Mass Laboratory Shallow Zone Radionuclides File : 600-111_shallow_Rad.RAD

$\begin{array}{lllllll}\text { PU-240 } & 1.060 E-01 & 0.000 E+00 & 4.264 E-01 & 3.518 E+01 & 4.264 E-01 & 3.518 E+01\end{array}$

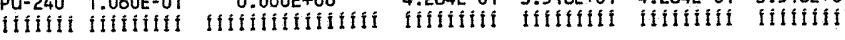


ATTACHMENT 2

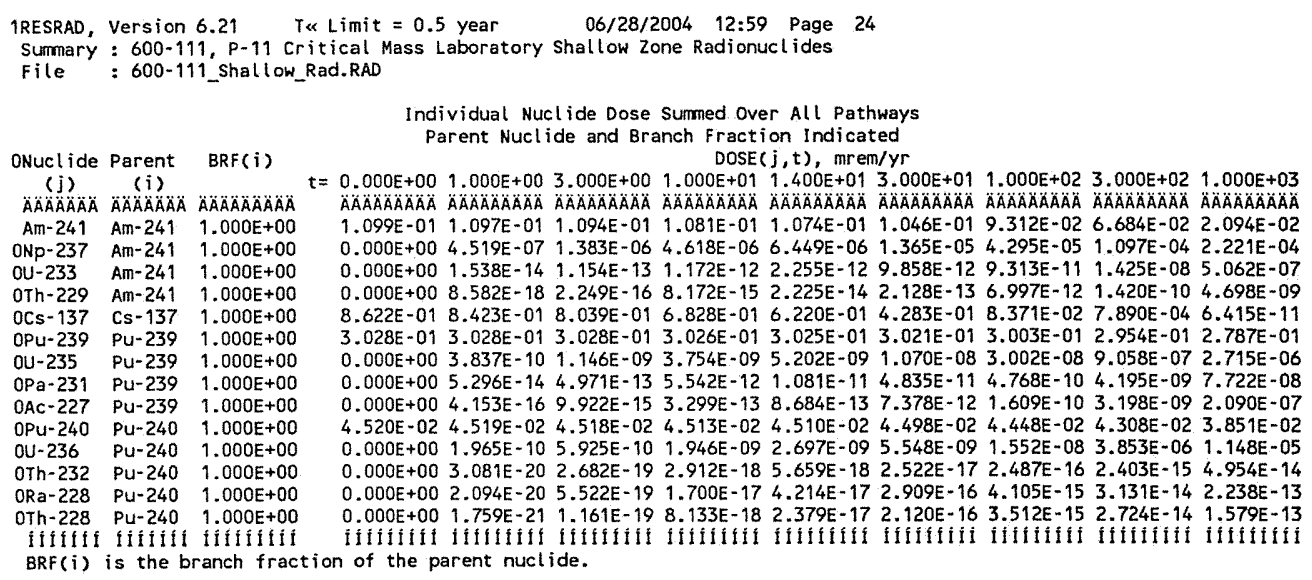

$\operatorname{BRF}(i)$ is the branch fraction of the parent nuclide. 


\section{ATTACHMENT 2}

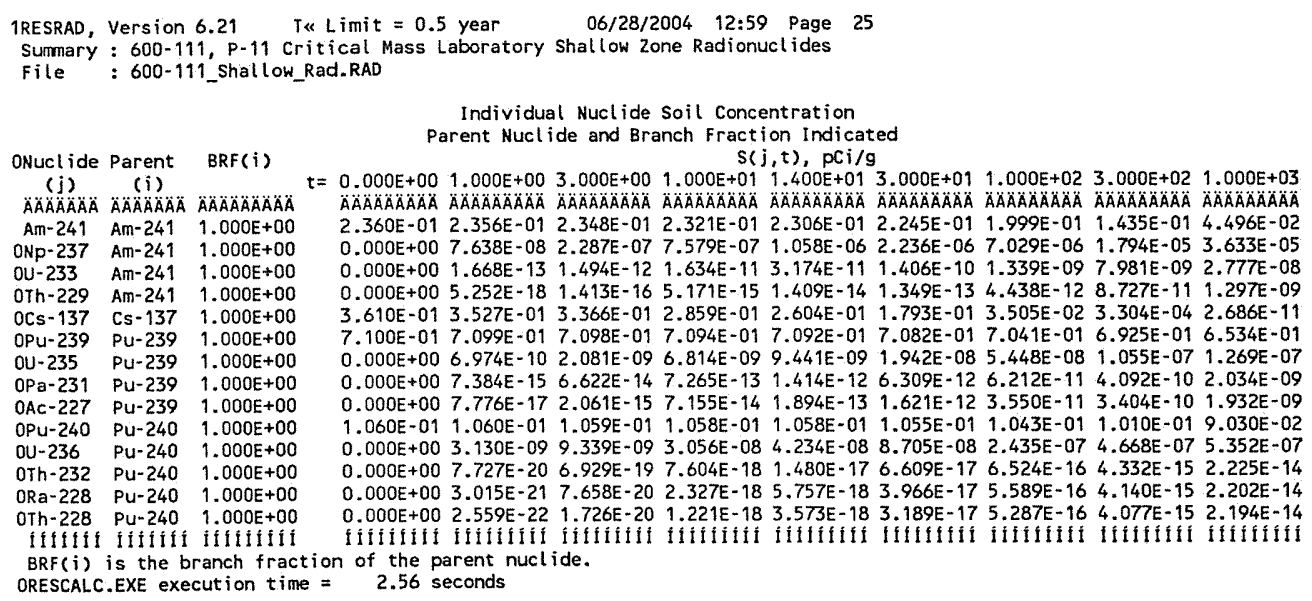

\begin{tabular}{|c|c|}
\hline 2 & of 25 \\
\hline or S.W.C & \\
\hline M.T. Stank & Dat \\
\hline & $\mathrm{Re}$ \\
\hline
\end{tabular}




\section{ATTACHMENT 3}

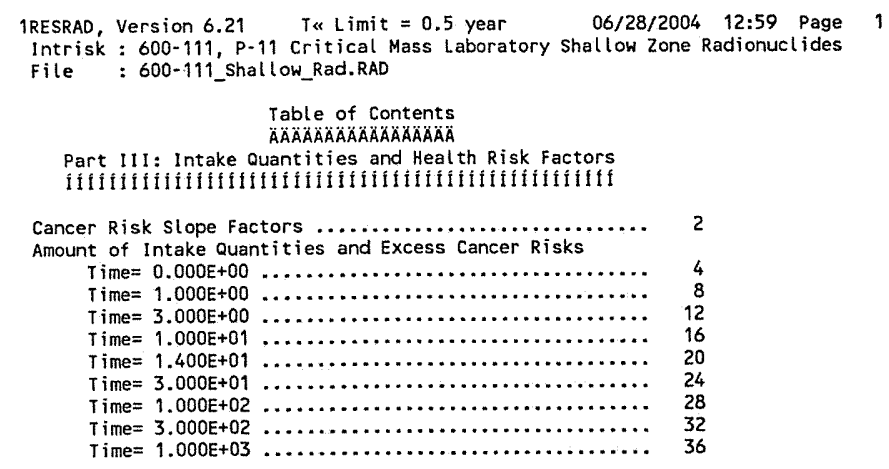

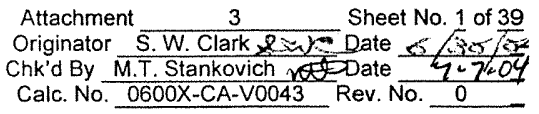




\section{ATT ACHMENT 3}

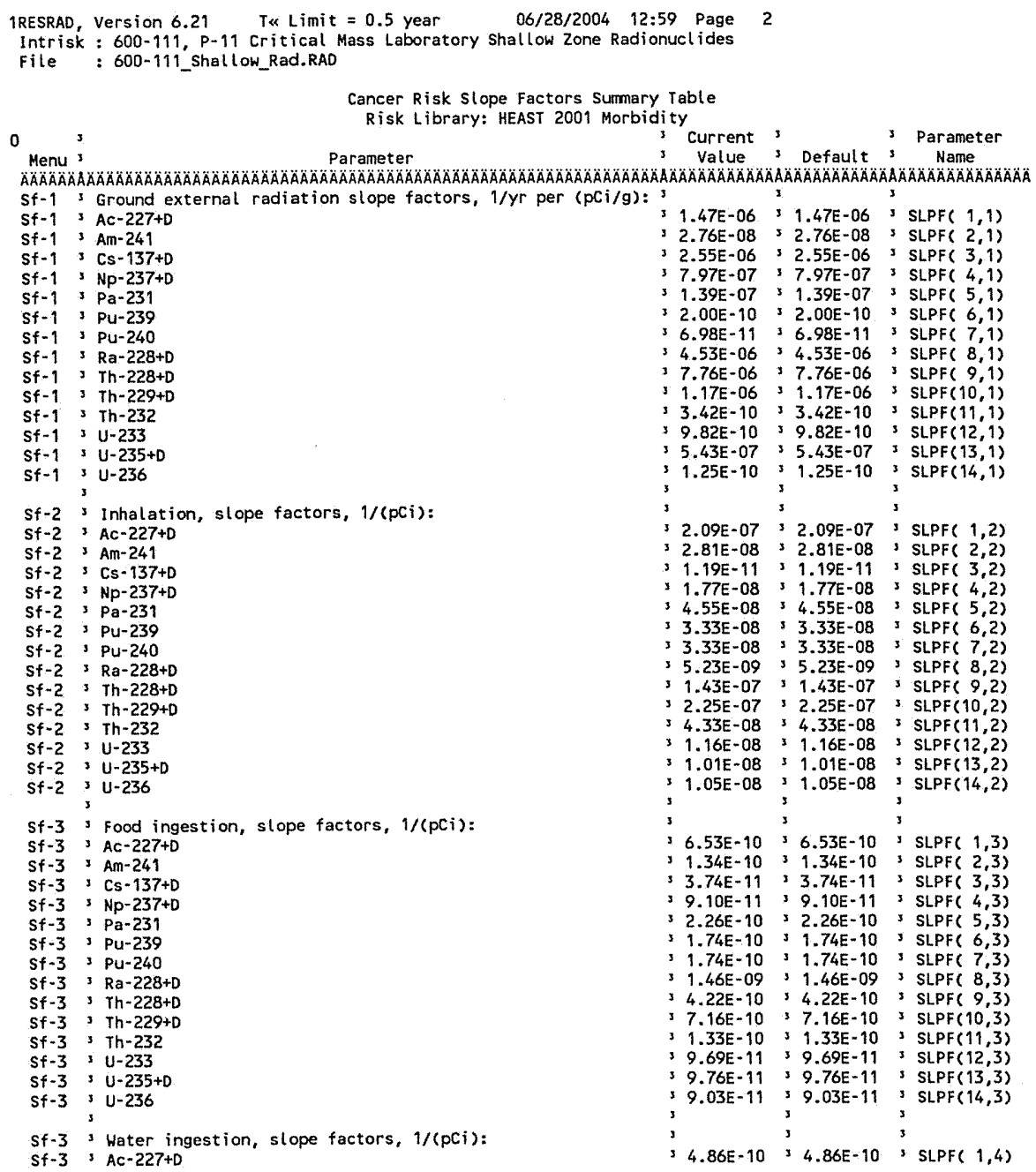

\begin{tabular}{|c|c|}
\hline Attachment $\quad 3$ & Sheet No. 2 of 39 \\
\hline Originator S.W. Clark & Date \\
\hline Chk'd By M.T. Stankovich & Date \\
\hline Calc. No. $0600 \mathrm{X}$-CA-V0043 & Rev. No. \\
\hline
\end{tabular}




\section{ATTACHMENT 3}

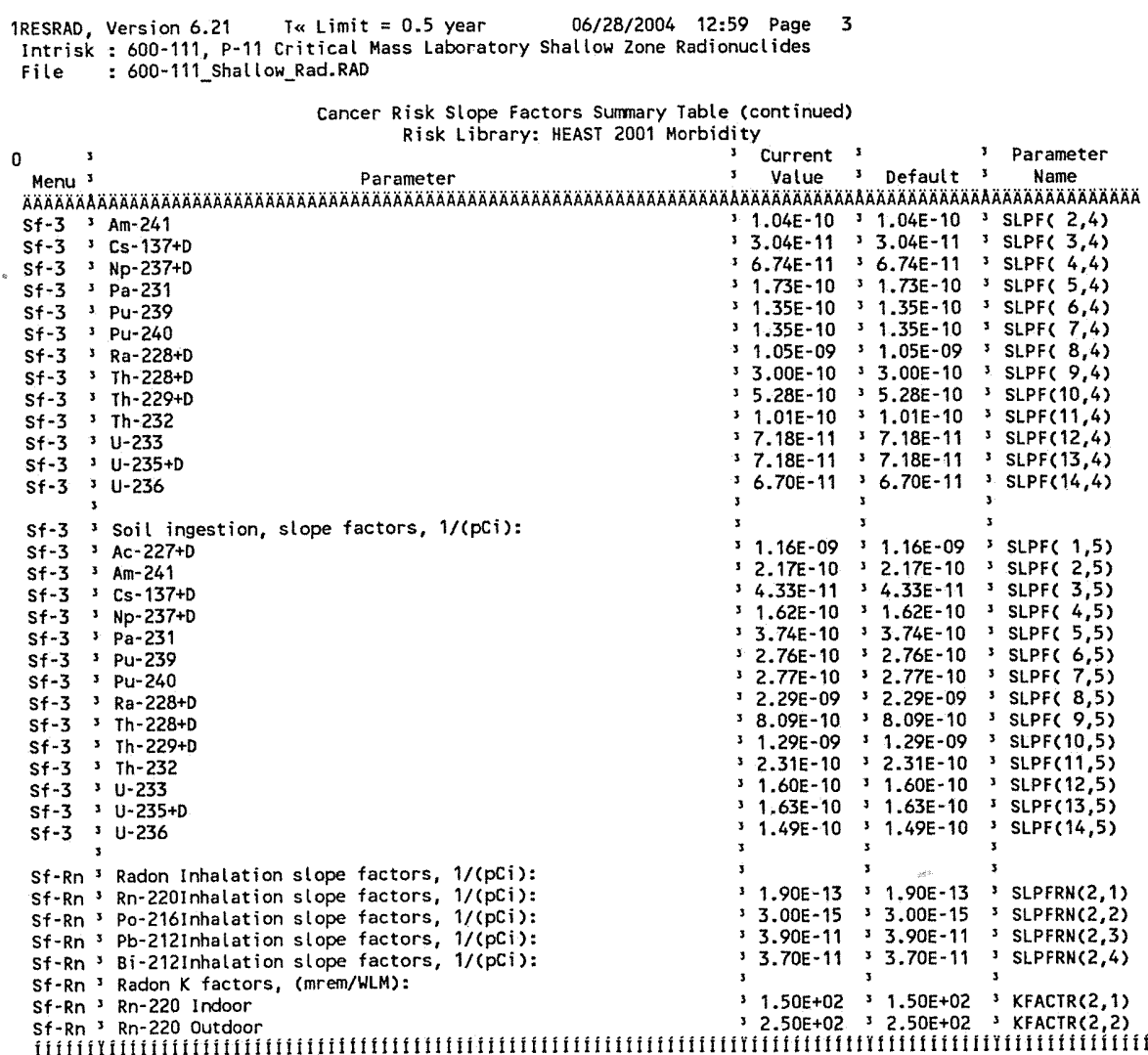

\begin{tabular}{ll} 
Attachment $\frac{3}{\text { S.W. Clark }}$ & Sheet No. 3 of 39 \\
Originator & Date \\
Chk'd By M.T. Stankovich & Date \\
Calc. No. 0600X-CA-V0043 Rev. No. 0 \\
\hline
\end{tabular}




\section{ATTACHMENT 3}

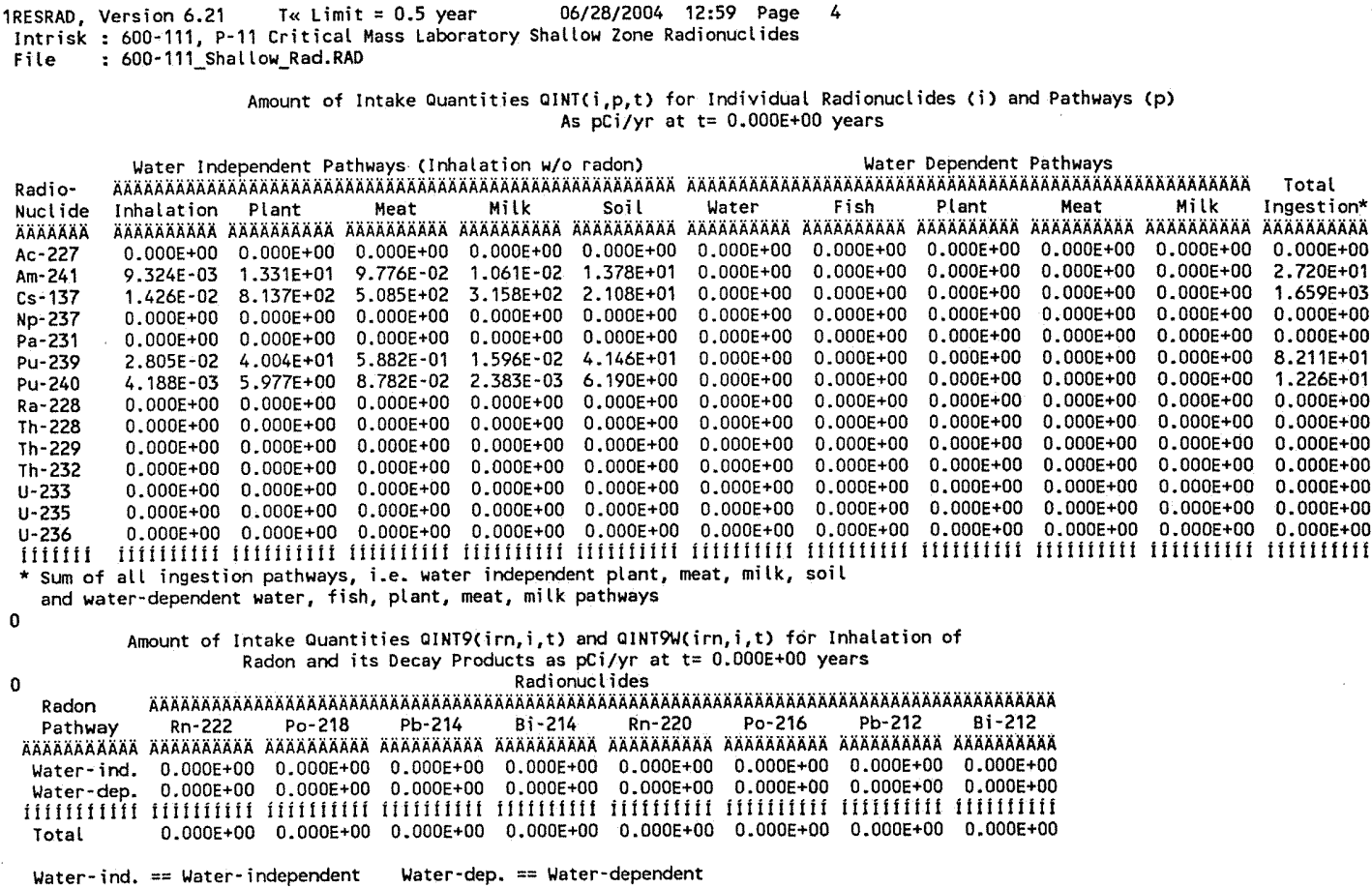

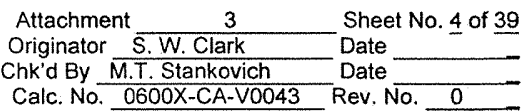




\section{ATTACHMENT 3}

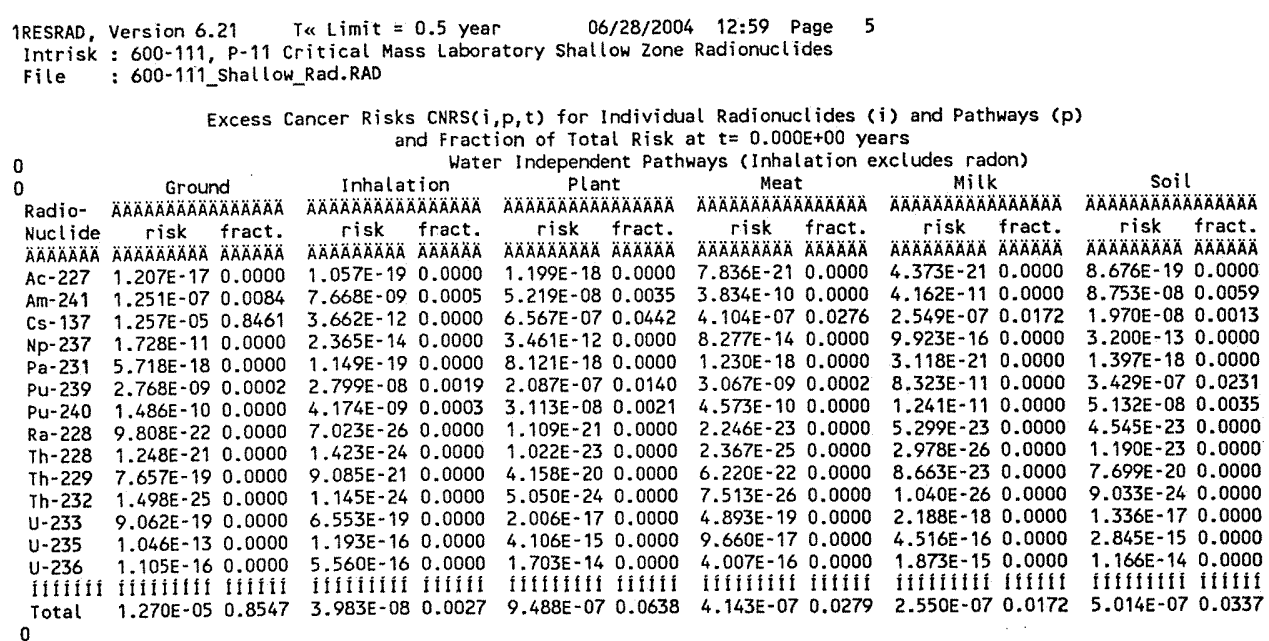

$$
\begin{gathered}
\text { Excess Cancer Risks CNRS( } i, p, t) \text { for Individual Radionuclides (i) and Pathways }(p) \\
\text { and Fraction of Total Risk at } t=0.000 E+00 \text { years }
\end{gathered}
$$

\begin{tabular}{|c|c|c|c|c|c|c|c|c|c|c|c|c|}
\hline \multirow{2}{*}{\begin{tabular}{l} 
Radio- \\
Nuclide \\
\hdashline$A A B A B A B A B A$
\end{tabular}} & $\begin{array}{r}\text { Water } \\
\text { AAAAAAAAAOAA }\end{array}$ & $\triangle A B A A A A B$ & \multicolumn{2}{|c|}{ Fish } & \multicolumn{2}{|c|}{ Plant } & \multicolumn{2}{|l|}{ Meat } & \multicolumn{2}{|l|}{ Milk } & \multicolumn{2}{|c|}{$\begin{array}{r}\text { All Pathways*** } \\
\text { AAAAAAAAAAAAAOAAA }\end{array}$} \\
\hline & $\begin{array}{c}\text { risk } \\
\text { AAAAAAAAAAA }\end{array}$ & $\begin{array}{l}\text { fract. } \\
A ̈ A ̈ A A O A\end{array}$ & $\begin{array}{c}\text { risk } \\
\triangle A A A B A B A B A\end{array}$ & $\begin{array}{l}\text { fract: } \\
\text { ÄAOAOAOA }\end{array}$ & $\begin{array}{c}\text { risk } \\
\triangle A A A A B A B A B A\end{array}$ & $\begin{array}{l}\text { fract. } \\
\text { ÄÄÄÄÄA }\end{array}$ & $\begin{array}{c}\text { risk } \\
\triangle A \cap A \cap A B A B A B A\end{array}$ & $\begin{array}{l}\text { fract. } \\
\text { ÄABAAA }\end{array}$ & $\begin{array}{c}\text { risk } \\
\triangle A A B A B A B A B A B A\end{array}$ & $\begin{array}{l}\text { fract. } \\
\triangle A A \not A A X A ̈\end{array}$ & $\begin{array}{l}\text { riSK } \\
\text { AAAOAOAOAOAOA }\end{array}$ & fract: \\
\hline$A c-227$ & $0.000 E+00$ & 0.0000 & $0.000 E+00$ & 0.0000 & $0.000 E+00$ & 0.0000 & $0.000 E+00$ & 0.0000 & $0.000 E+00$ & 0.0000 & $1.425 \mathrm{E}-17$ & 0.0000 \\
\hline$A m-241$ & $0.000 E+00$ & 0.0000 & $0.000 E+00$ & 0.0000 & $0.000 E+00$ & 0.0000 & $0.000 E+00$ & 0.0000 & $0.000 \mathrm{E}+00$ & 0.0000 & 2.730E-07 & 0.0184 \\
\hline Cs -137 & $0.000 E+00$ & 0.0000 & $0.000 E+00$ & 0.0000 & $0.000 E+00$ & 0.0000 & $0.000 E+00$ & 0.0000 & $0.000 E+00$ & 0.0000 & $1.392 E-05$ & 0.9364 \\
\hline & $0.000 E+00$ & 0.0000 & $0.000 E+00$ & 0.0000 & $0.000 E+00$ & 0.0000 & $0.000 E+00$ & 0.0000 & $0.000 \mathrm{E}+00$ & 0.0000 & $2.117 \mathrm{E}-110$ & 0.000 \\
\hline$P a-231$ & $0.000 \mathrm{E}+00$ & 0.0000 & $0.000 E+00$ & 0.0000 & $0.000 E+00$ & 0.0000 & $0.000 E+00$ & 0.0000 & $0.000 E+00$ & 0.0000 & 1.658 & 0.0000 \\
\hline & $0.000 E+00$ & 0.0000 & $0.000 E+00$ & 0.0000 & $0.000 E+00$ & 0.0000 & $0.000 E+00$ & 0.00 & $0.000 E+00$ & 0.0000 & $E-07$ & \\
\hline Pu- 240 & $0.000 \mathrm{E}+00$ & 0.0000 & $0.000 E+00$ & 0.0000 & $0.000 E+00$ & 0.0000 & $0.000 E+00$ & 0.0000 & $0.000 E+C 0$ & 0.0000 & $8.724 E-08$ & 0.0059 \\
\hline$R a-228$ & $0.000 \mathrm{E}+00$ & 0.0000 & $0.000 E+00$ & 0.0000 & $0.000 E+00$ & 0.0000 & 0.000 & 0.0000 & $0.000 E+00$ & 0.0000 & $2.211 E-21$ & 0.0000 \\
\hline$T h-228$ & $0.000 E+00$ & 0.0000 & $0.000 E+00$ & 0.0000 & $0.000 E+00$ & 0.0000 & $0.000 E+00$ & 0.0000 & $0.000 E+00$ & 0.0000 & $1.271 E-21$ & 0.0000 \\
\hline Th-229 & 0.000 & 0.0000 & $0.000 E+00$ & 0.0000 & $0.000 E+00$ & 0.0000 & $0.000 E+00$ & 0.0000 & $0.000 E+00$ & 0.0000 & $8.940 E-19$ & 0.0000 \\
\hline Th-232 & $0.000 E+00$ & 0.0000 & $0.000 E+00$ & 0.0000 & $0.000 E+00$ & 0.0000 & 0.000 & 0.00 & $0.000 E+00$ & 0.0000 & $1.546 \mathrm{E}-23$ & 0.0000 \\
\hline$U-233$ & $0.000 E+00$ & 0.0000 & $0.000 E+00$ & 0.0000 & $0.000 E+00$ & 0.0000 & $0.000 E+00$ & 0.0000 & $0.000 E+00$ & 0.0000 & $3.765 \mathrm{E}-17$ & 0.0000 \\
\hline U-235 & $0.000 \mathrm{E}+00$ & 0.0000 & $0.000 E+00$ & 0.0000 & $0.000 E+00$ & 0.0000 & 0.08 & & $0.000 E+00$ & 0.00 & $1.122 E-13$ & 0.0000 \\
\hline & $0.000 E+00$ & & $0.000 \mathrm{E}+00$ & 0.0000 & 0.000 & 0.0000 & 0.08 & 0.0000 & $0.000 E+00$ & 0.0000 & $3.164 \mathrm{E}-14$ & 0.0000 \\
\hline ffifiti & fiffilifi & ififil & fifilfifi & fitifi & & flifit & & & lifilitifi & & fifilifi & Iiilit \\
\hline Total & $0.000 E+00$ & 0.0000 & $0.000 E+00$ & 0.0000 & 0.000 & 0.0000 & $0.000 E+00$ & 0.0000 & $0.000 E+00$ & 0.0000 & $1.486 E-05$ & 1.0000 \\
\hline
\end{tabular}

Water Dependent Pathways

Attachment $\frac{3}{\text { S.W. Clark }}$ 
ATTACHMENT 3

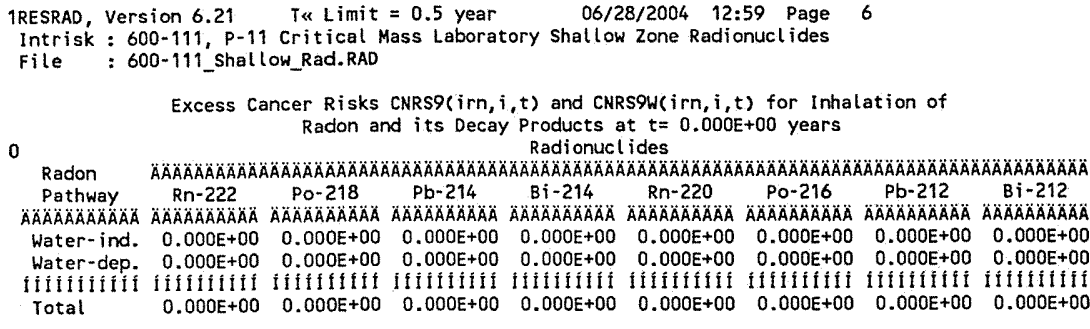

Attachment 


\section{ATTACHMENT 3}

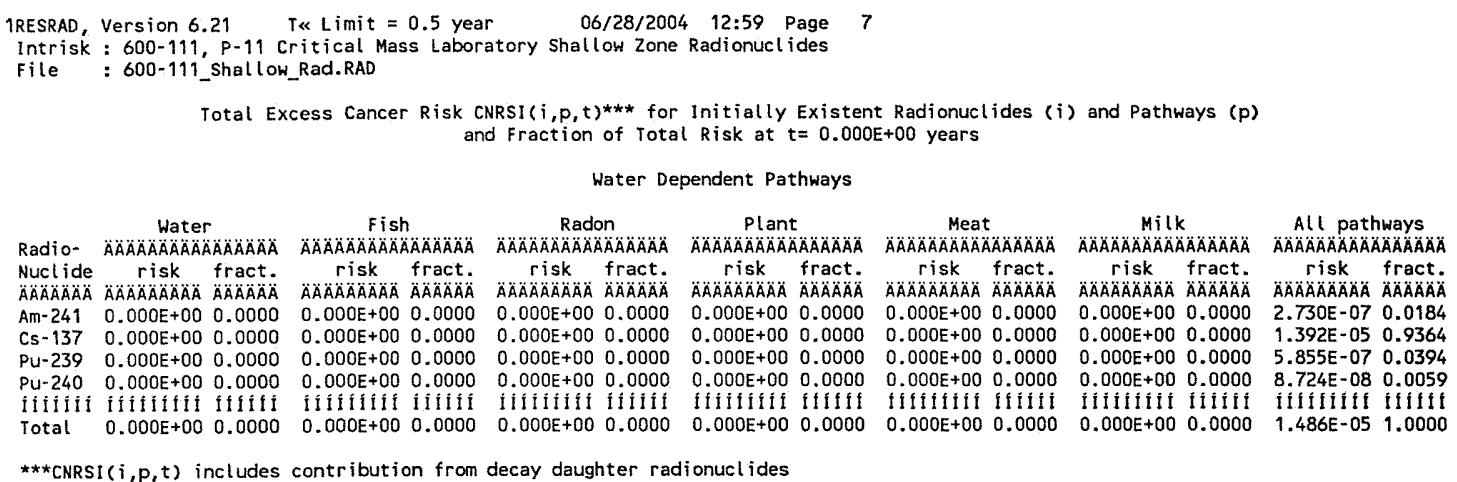




\section{ATTACHMENT 3}

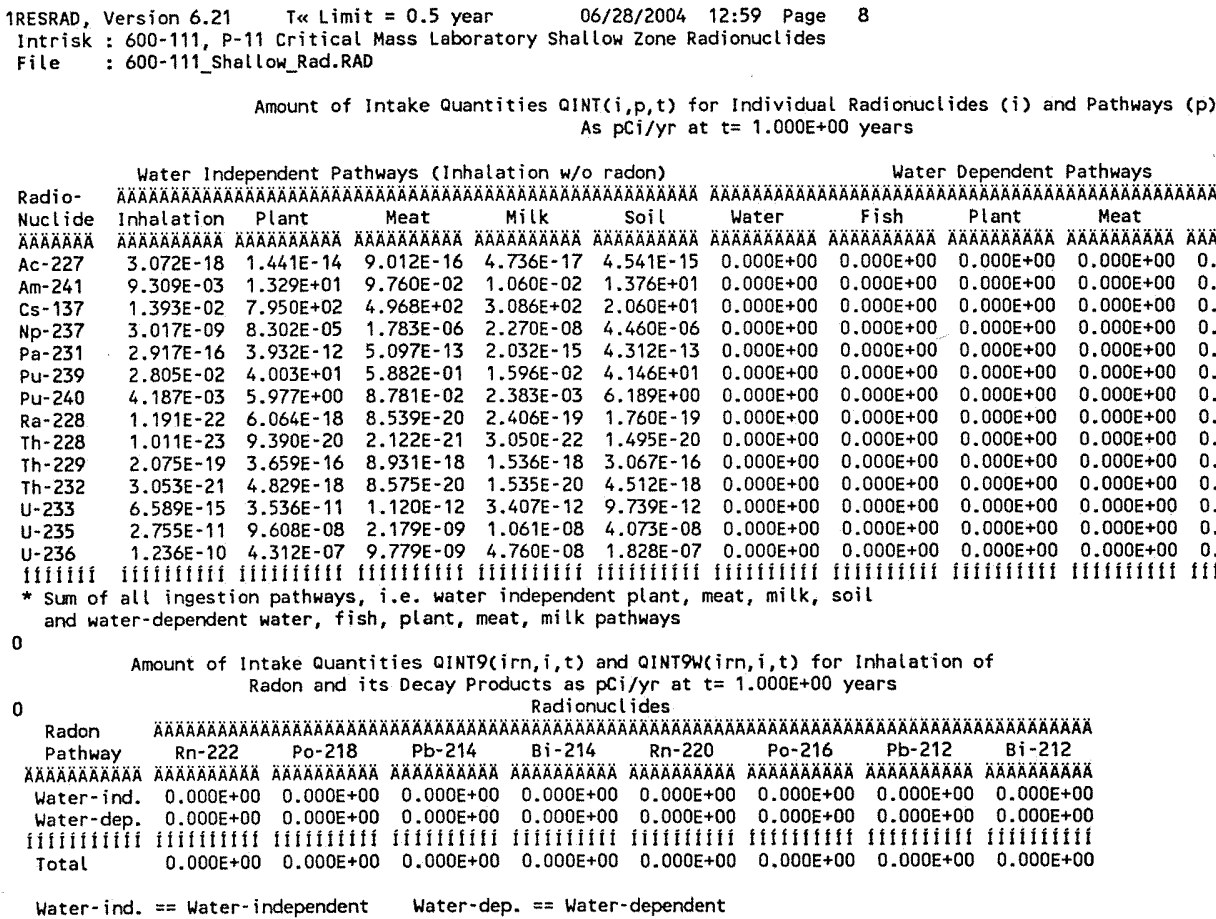

\begin{tabular}{|c|c|}
\hline Attachment & Sheet No. 8 of 39 \\
\hline Originator S.W. Clark & Date \\
\hline Chk'd By M.T.Stankovich & Date \\
\hline Calc. No. $0600 X-C A-V 0043$ & Rev. No. \\
\hline
\end{tabular}




\section{ATTACHMENT 3}

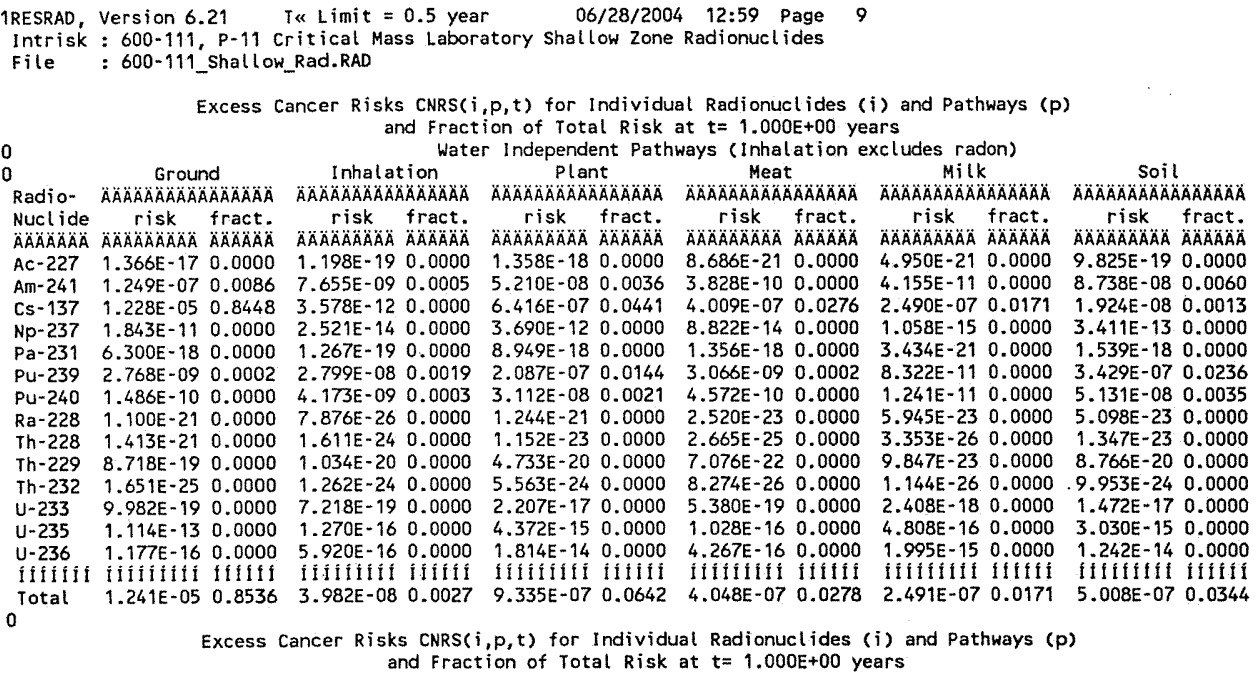

Excess Cancer Risks CNRS( $i, p, t)$ for Individual Radionuclides (i) and Pathways $(p)$

and Fraction of Total Risk at $t=1.000 E+00$ years

Water Dependent Pathways

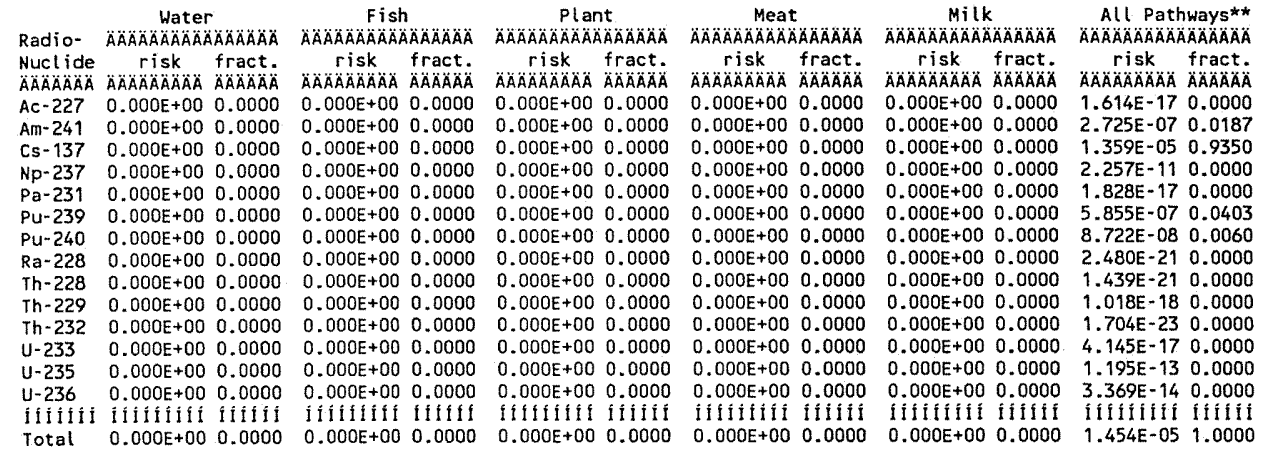

** Sum of water independent ground, inhalation, plant, meat, milk, soil

and water dependent water, fish, plant, meat, milk pathways

Attachment $\frac{3}{\text { S.W. Clark }}$ Sheet No. 9 of 39
Originator
Chk'd By M.T. Stankovich
Cate
Calc. No. 0600X-CA-V0043 Rev. No. 0




\section{ATTACHMENT 3}

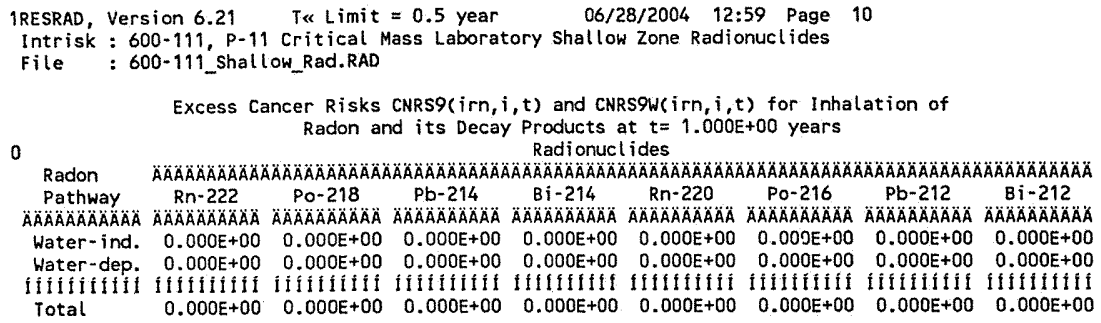




\section{ATTACHMENT 3}

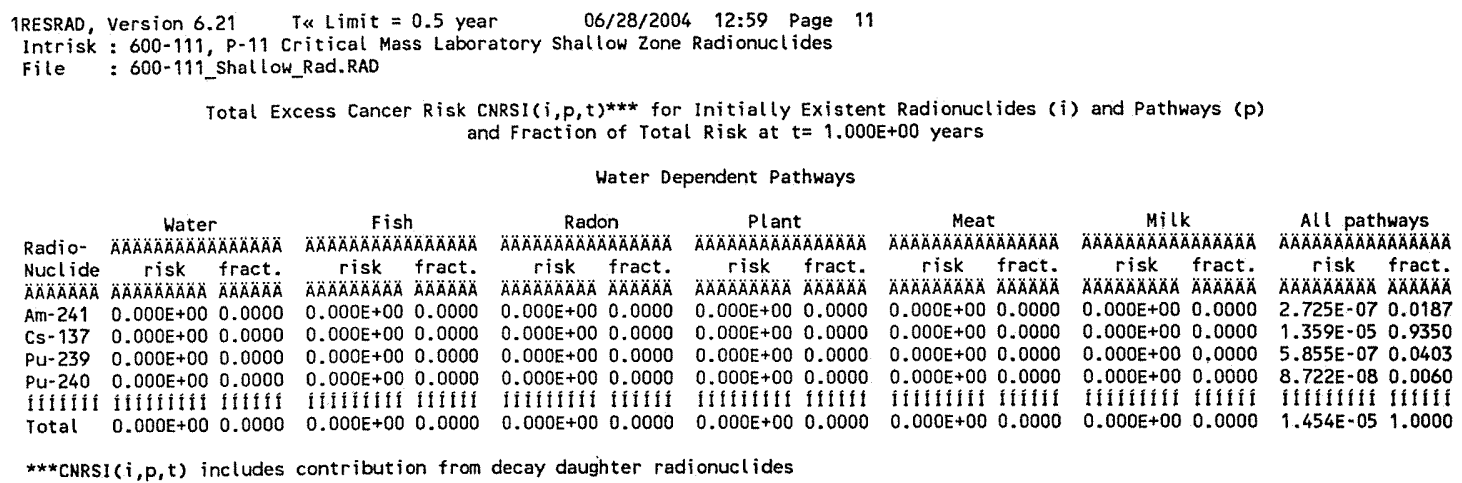

Water Dependent Pathways

\begin{tabular}{|c|c|c|c|c|c|c|c|c|c|c|c|c|}
\hline & Water & $\begin{array}{c}\text { Fish } \\
\triangle A A A A A A A A A B A A O A O A\end{array}$ & 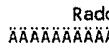 & on & $\begin{array}{r}P \text { ant } \\
A A A A A A B A B A B\end{array}$ & $\triangle A A A A A A A B$ & $\begin{array}{r}\text { Meat } \\
\triangle A A A A B A A B A A B A\end{array}$ & $\triangle \triangle A O A A ̈ A$ & $\begin{array}{r}M i \\
A O A A A O A O A O A \\
\end{array}$ & AAOAAAA & $\begin{array}{l}\text { All path } \\
A A B A A A A A A B A\end{array}$ & $\begin{array}{l}\text { hways } \\
A B A A B A A A A\end{array}$ \\
\hline & & $\begin{array}{l}\text { risk fract. } \\
\text {. }\end{array}$ & $\begin{array}{c}\text { risk } \\
\text { AAAAOAOAAAA }\end{array}$ & & $\begin{array}{c}\text { risk } \\
\text { AAAAAAAAÄ }\end{array}$ & & risk & & $\begin{array}{c}\text { risk } \\
\triangle A A B A B A A O A A\end{array}$ & & & \\
\hline & $\begin{array}{l}\text { AAA } \\
0.0\end{array}$ & $E+00 \quad 0.0000$ & $0.000 E+00$ & 0.0000 & 0.000 & .0000 & & 0.0 & $1 O E+00$ & & & \\
\hline & 000. & 00.0 & & & & & & & & & & \\
\hline & & 000.0 & & 0.0 & 0.0 & & & & & & & \\
\hline & 0.0 & & & & & & & & & & & \\
\hline & & & & & & & & & & & & \\
\hline & & $0.000 E+00 \quad 0.0000$ & $0.000 E+00$ & 0.0000 & $0.000 E+00$ & 0.0000 & $0.000 E+00$ & 0.0000 & $0.000 E+00$ & 0.0000 & $1.454 E-05$ & 1.0000 \\
\hline
\end{tabular}

$\star * *$ CNRSI $(i, p, t)$ includes contribution from decay daughter radionuclides

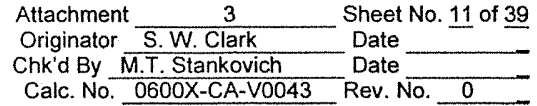




\section{ATTACHMENT 3}

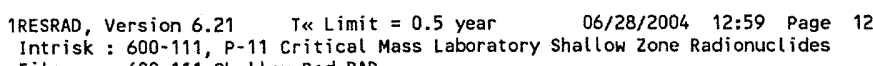

Water-dep. = Water-dependent

\begin{tabular}{|c|c|}
\hline Attachment & Sheet No. 12 of 39 \\
\hline Originator S.W. Clark & Date \\
\hline Chk'd By M.T. Stankovich & Date \\
\hline alc. No. $0600 \mathrm{X}-\mathrm{CA}-\mathrm{V} 0043$ & Rev. No. \\
\hline
\end{tabular}




\section{ATTACHMENT 3}

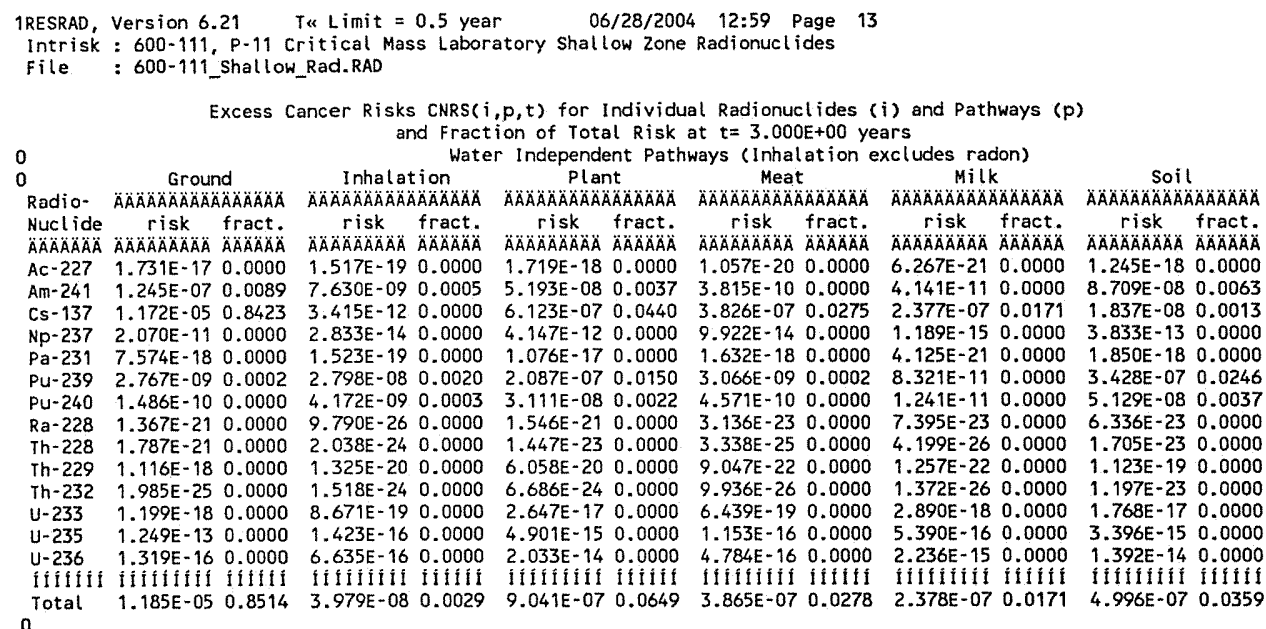

Excess Cancer Risks CNRS $(i, p, t)$ for Individual Radionuclides (i) and Pathways $(p)$

and Fraction of Total Risk at $t=3.000 E+00$ years

Water Dependent Pathways

\begin{tabular}{|c|c|c|c|c|c|c|c|c|c|c|c|c|}
\hline \multirow{2}{*}{$\begin{array}{l}\text { Radio- } \\
\text { Nucl ide } \\
A A B A A B A B A\end{array}$} & & Water & \multicolumn{2}{|c|}{ Fish } & \multicolumn{2}{|c|}{ Plant } & \multicolumn{2}{|c|}{ Meat } & \multicolumn{2}{|c|}{ Milk } & \multicolumn{2}{|c|}{ 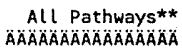 } \\
\hline & $\begin{array}{c}\text { risk } \\
\text { ÄAAAOAOÄÄA }\end{array}$ & & $\begin{array}{c}\text { risk } \\
\because A O A B A B A B A ̈\end{array}$ & & $\begin{array}{c}\text { risk } \\
\triangle A B A B A B A O A\end{array}$ & & $\begin{array}{c}r i s k \\
\triangle A A O A O A O A O A O A\end{array}$ & & $\begin{array}{c}\text { risk } \\
\text { AAAAAOAAAAAA }\end{array}$ & & $\begin{array}{c}\text { risK } \\
\text { AOAOAAAAAAAA }\end{array}$ & \\
\hline$A C-227$ & & & & & & & & & & & & \\
\hline & & & & & & & & & & & & \\
\hline & & & & & & & & & & & & \\
\hline & & & & & & & & & & & & \\
\hline & & & & & & & & & & & & \\
\hline & & & & & & & & & & & & \\
\hline & & & & & & & & & & & & \\
\hline & & & & & & & & & & & & \\
\hline & & & & & & & & & & & & \\
\hline & & & & & & & & & & & & \\
\hline & & & & & & & & & & & & \\
\hline & & & & & & & & & & & & \\
\hline & & & & & & & & & & & & \\
\hline & & & & & & & & & & & & \\
\hline & & & & & & & & & & & & \\
\hline 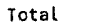 & & & & & & & & & & & & \\
\hline
\end{tabular}

** Sum of water independent ground, inhalation, plant, meat, milk, soil

and water dependent water, fish, plant, meat, milk pathways

\begin{tabular}{ll} 
Attachment & \multicolumn{1}{c}{$\begin{array}{c}\text { Sheet No. } 13 \text { of } 39 \\
\text { Originator S.W. Clark }\end{array}$} \\
Date & Date \\
Chk'd By M.T. Stankovich & Date \\
Calc. No. 0600X-CA-V0043 Rev. No. 0 \\
\hline
\end{tabular}




\section{ATTACHMENT 3}

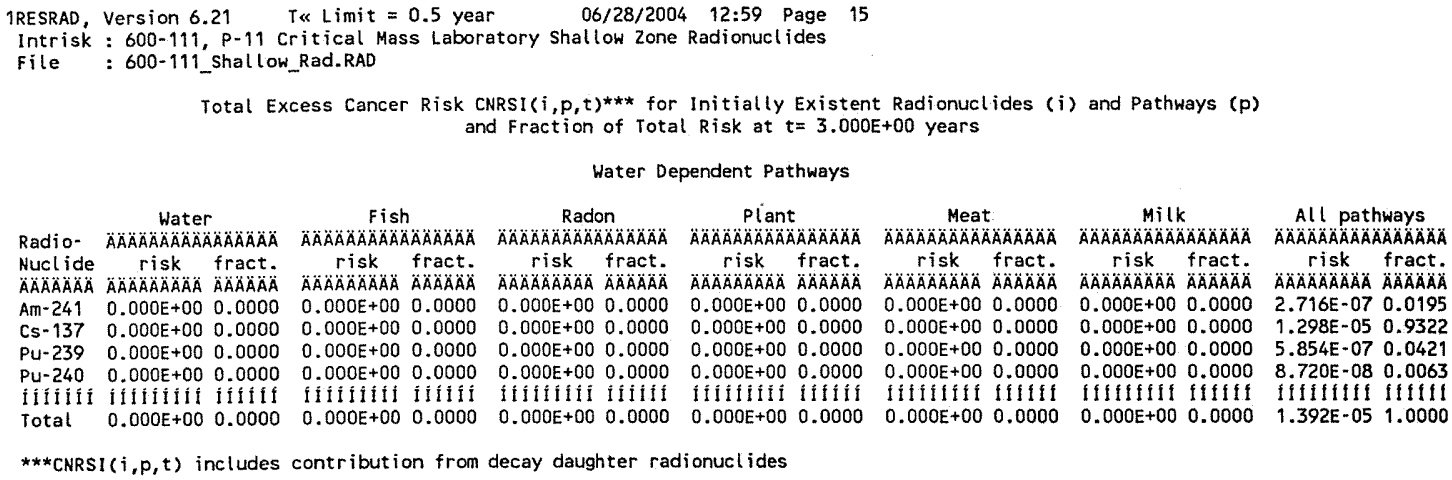

***CNRSI $(i, p, t)$ includes contribution from decay daughter radionuclides 


\section{ATTACHMENT 3}

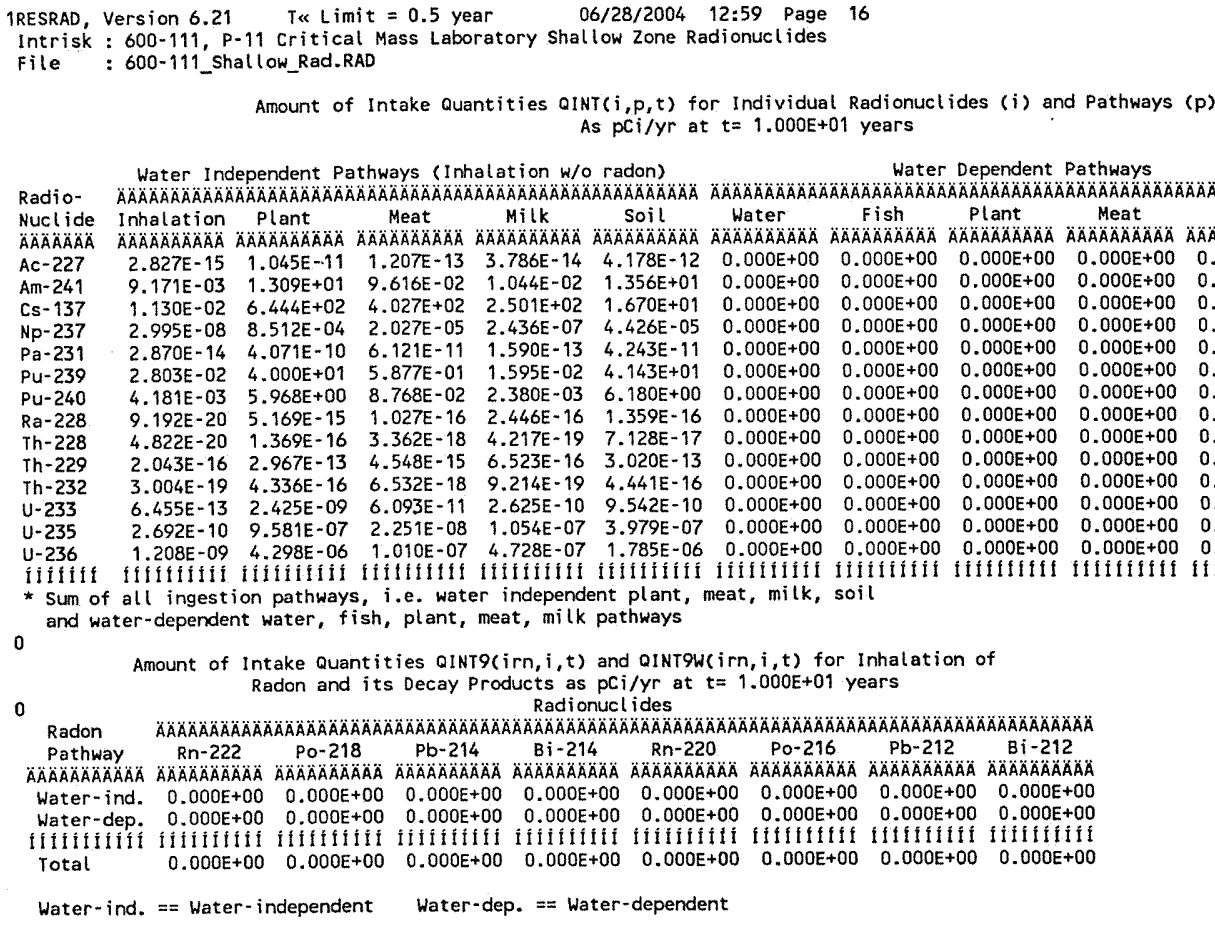

$\begin{array}{ll}\text { Attachment } \frac{3}{3} & \text { Sheet No. } 16 \text { of } 39 \\ \text { Originator S.W. Clark } & \text { Date } \\ \text { Chk'd By M.T. Stankovich } & \text { Date } \\ \text { Calc. No. 0600X-CA-V0043 } & \text { Rev. No. } 0\end{array}$




\section{ATTACHMENT 3}

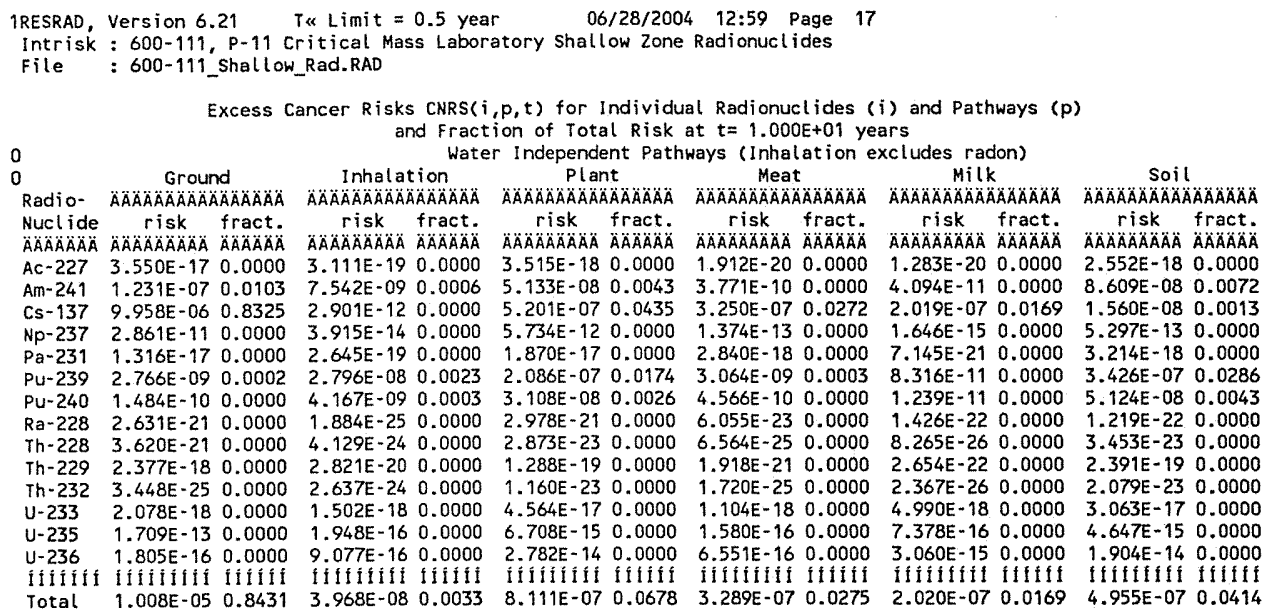

Water Dependent Pathways

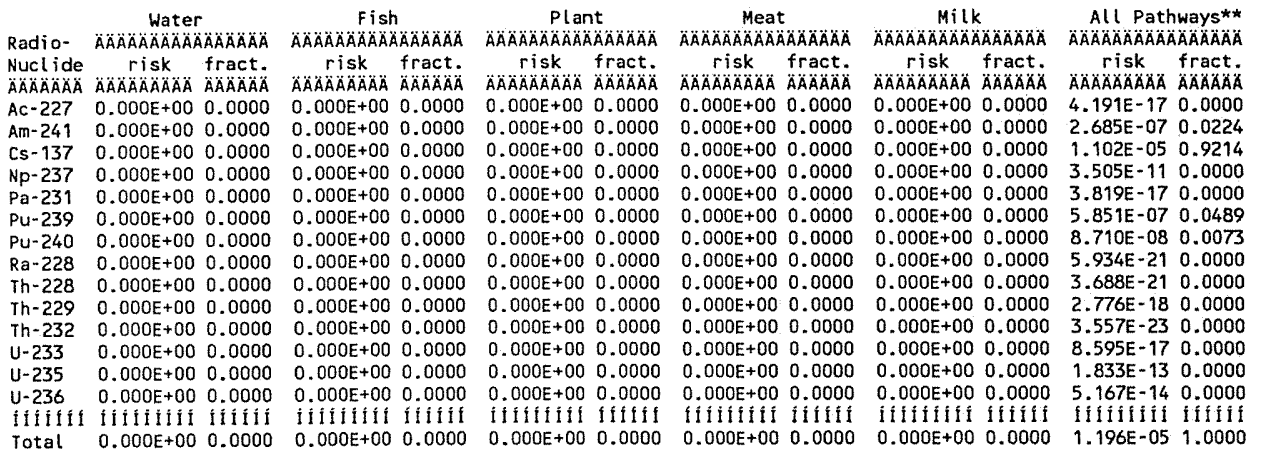

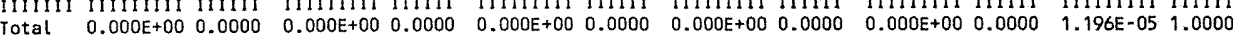

** Sum of water independent ground, inhalation, plant, meat, milk, soil

and water dependent water, fish, plant, meat, milk pathways

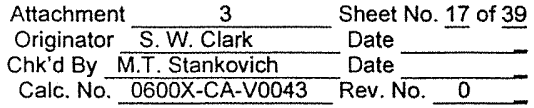




\section{ATTACHMENT 3}

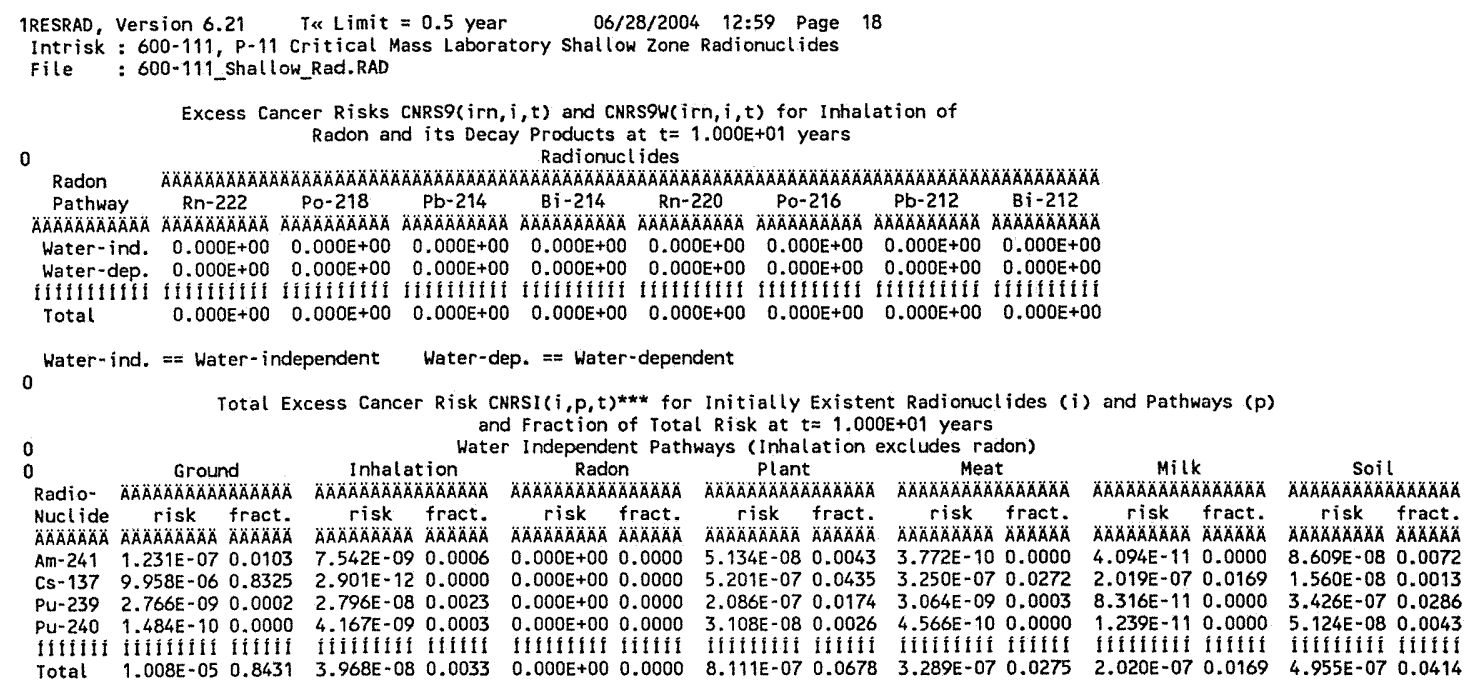

\begin{tabular}{|c|c|}
\hline achment & Sheet No. 18 of 39 \\
\hline Originator S. W. Clark & Date \\
\hline hk'd By M.T. Stankovich & Date \\
\hline
\end{tabular}




\section{ATTACHMENT 3}

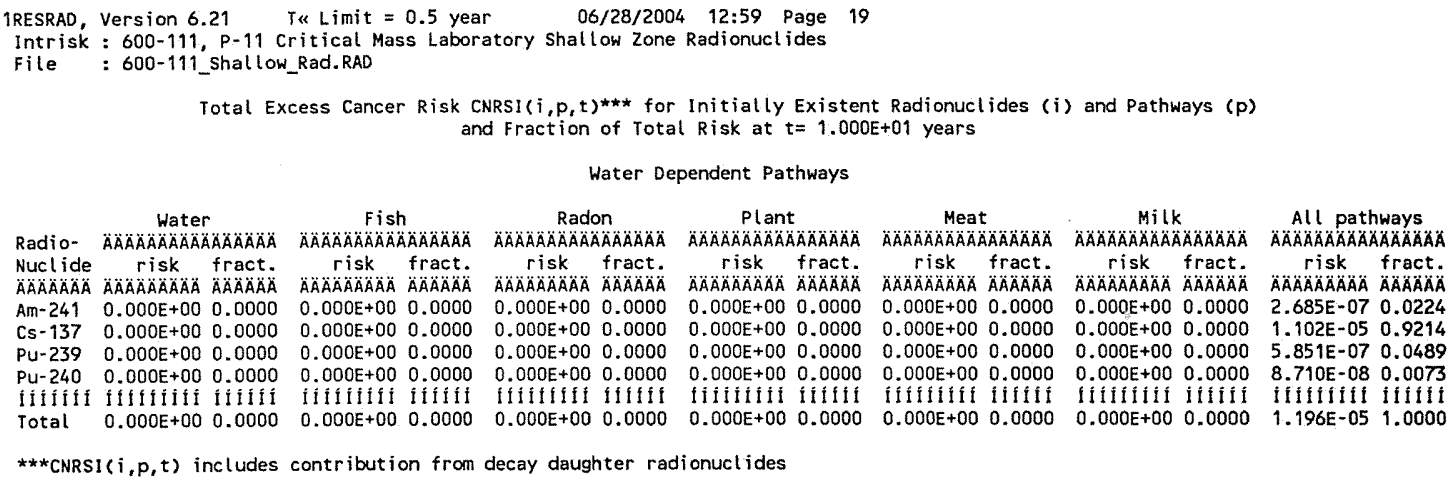

\begin{tabular}{l} 
Attachment $\frac{3}{\text { S.W. Clark }}$ Sheet No. 19 of 39 \\
Originator \\
Chk'd By M.T. Stankovich \\
Date \\
Calc. No. 0600X-CA-V0043 Rev. No. 0 \\
\hline
\end{tabular}




\section{ATTACHMENT 3}

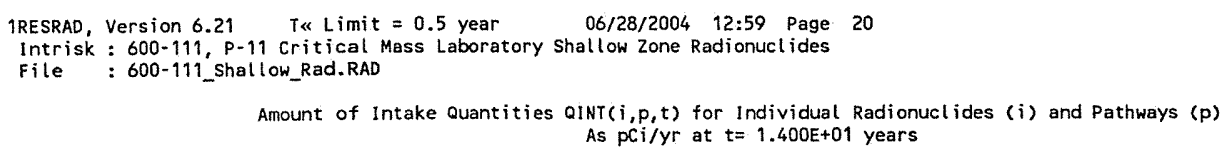

Water-ind. $==$ Water-independent Water-dep. $==$ Water-dependent 


\section{ATTACHMENT 3}

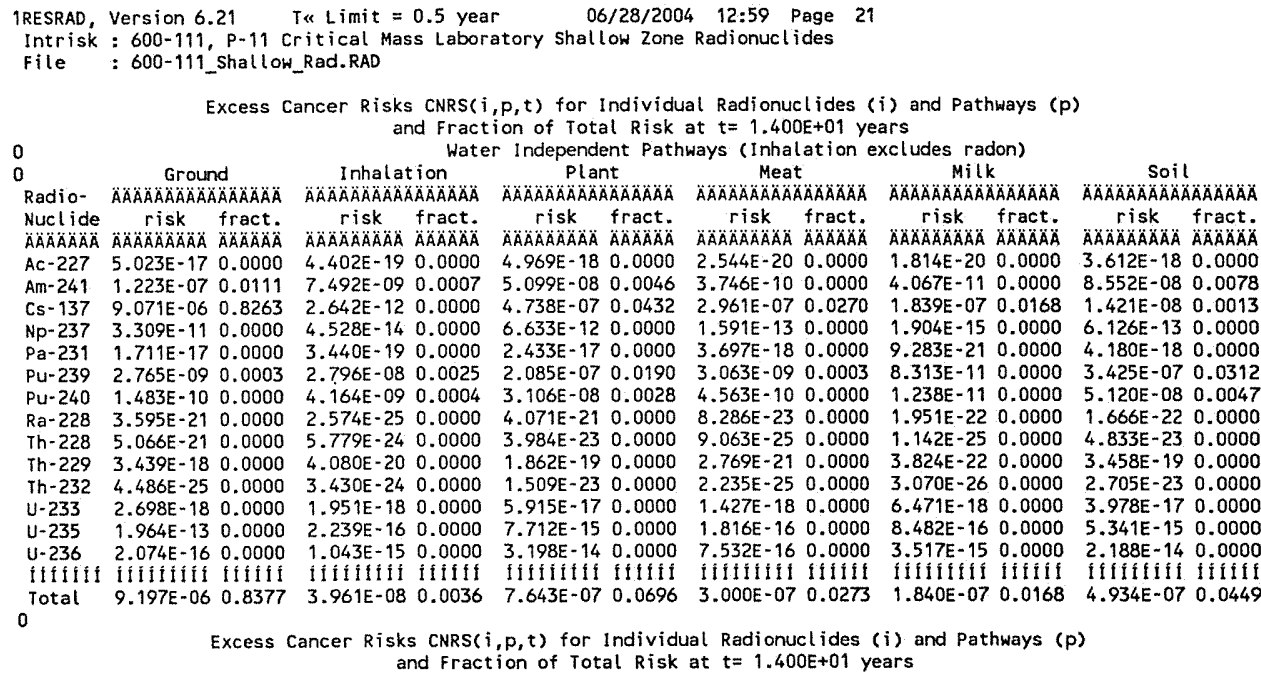
0

Excess Cancer Risks CNRS $(i, p, t)$ for Individual Radionuclides (i) and Pathways $(p)$ and Fraction of Total Risk at $t=1.400 E+01$ years

Water Dependent Pathways

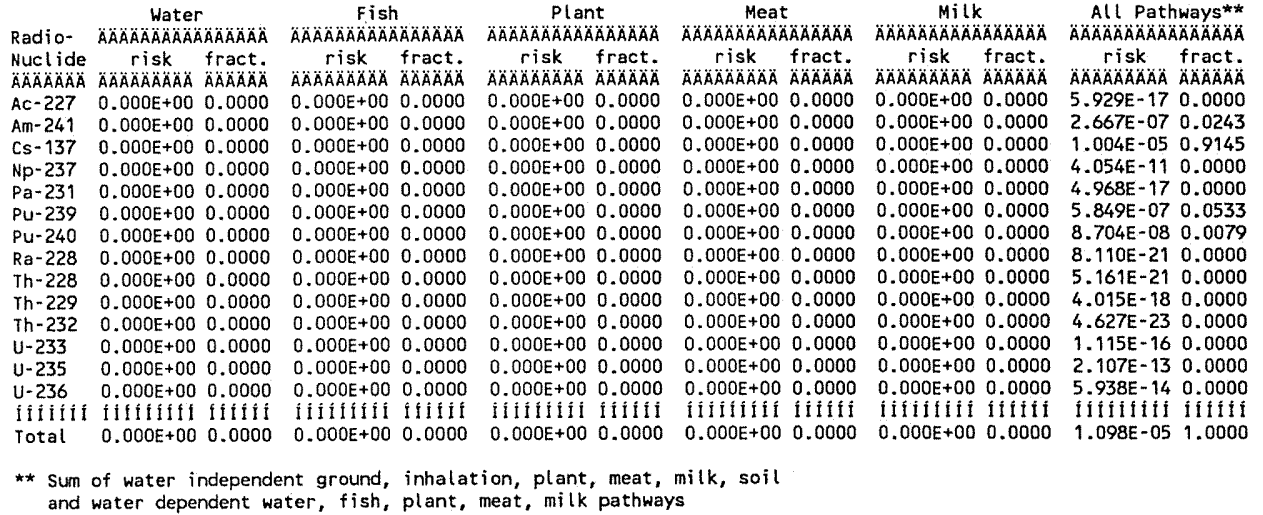

and water dependent water, fish, plant, meat, milk pathways

\begin{tabular}{|c|c|}
\hline Attachment & Sheet No. 21 of 39 \\
\hline Originator S.W. Clark & Date \\
\hline Chk'd By M.T. Stankovich & Date \\
\hline Calc. No. $0600 \mathrm{X}$-CA-V0043 & Rev. $\Lambda$ \\
\hline
\end{tabular}




\section{ATTACHMENT 3}

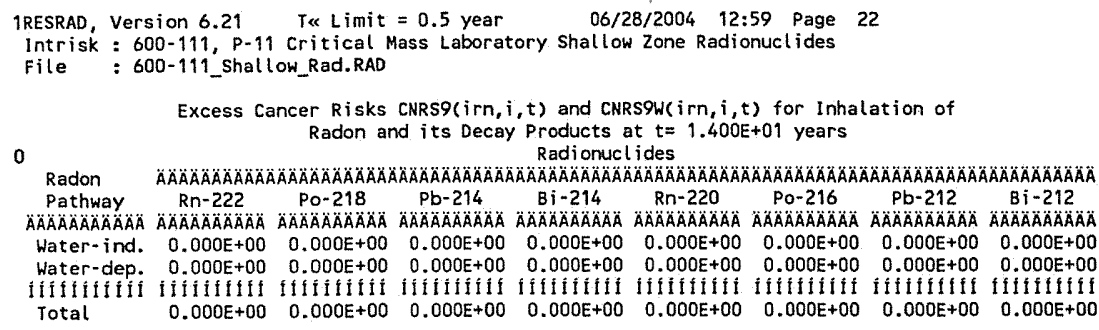

\begin{tabular}{|c|c|}
\hline Attachment $\quad 3$ & Sheet No. 22 of $\underline{39}$ \\
\hline Originator S.W. Clark & Date - - \\
\hline Chk'd By M.T. Stankovich & Date \\
\hline Calc. No. $0600 X$-CA-V0043 & Rev. No. \\
\hline
\end{tabular}




\section{ATTACHMENT 3}

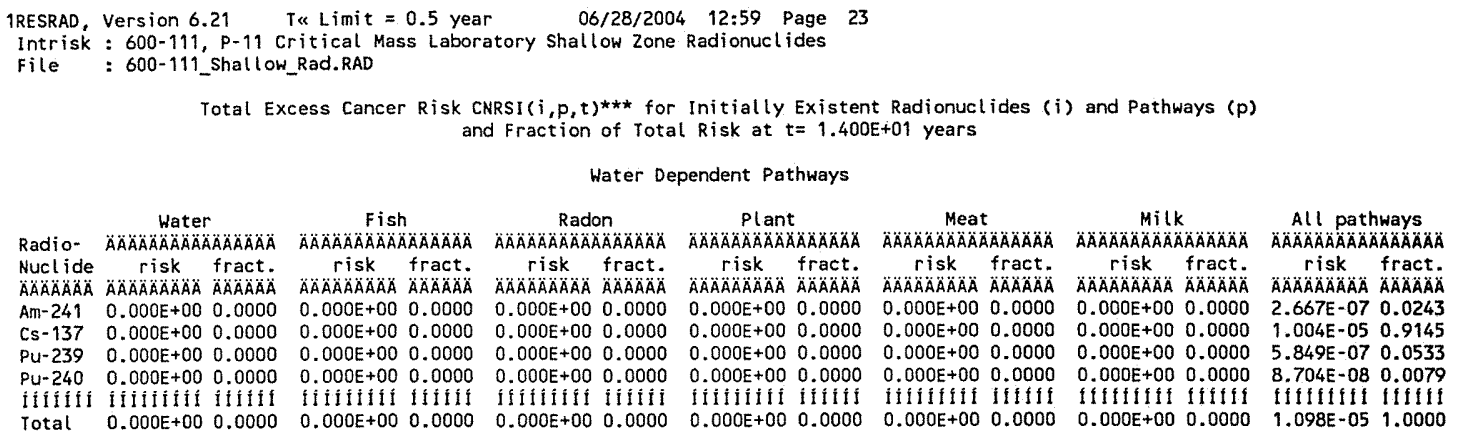

Attachment $\frac{3}{\text { S.W. Clark }}$ Date
Originator $\underline{23}$ of 39
Chk'd By M.T. Stankovich
Calc. No. 0600 Date-CA-V0043 Rev. No. 0
Mo




\section{ATTACHMENT 3}

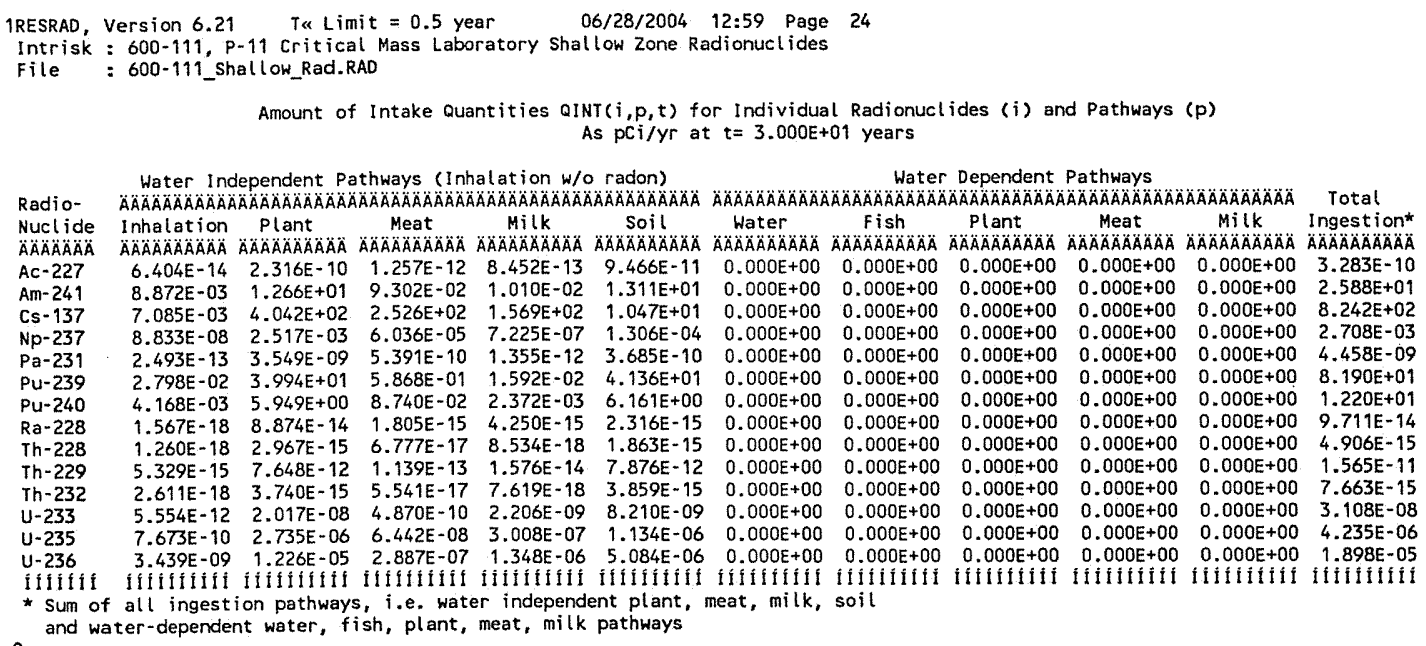

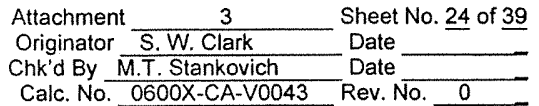




\section{ATTACHMENT 3}

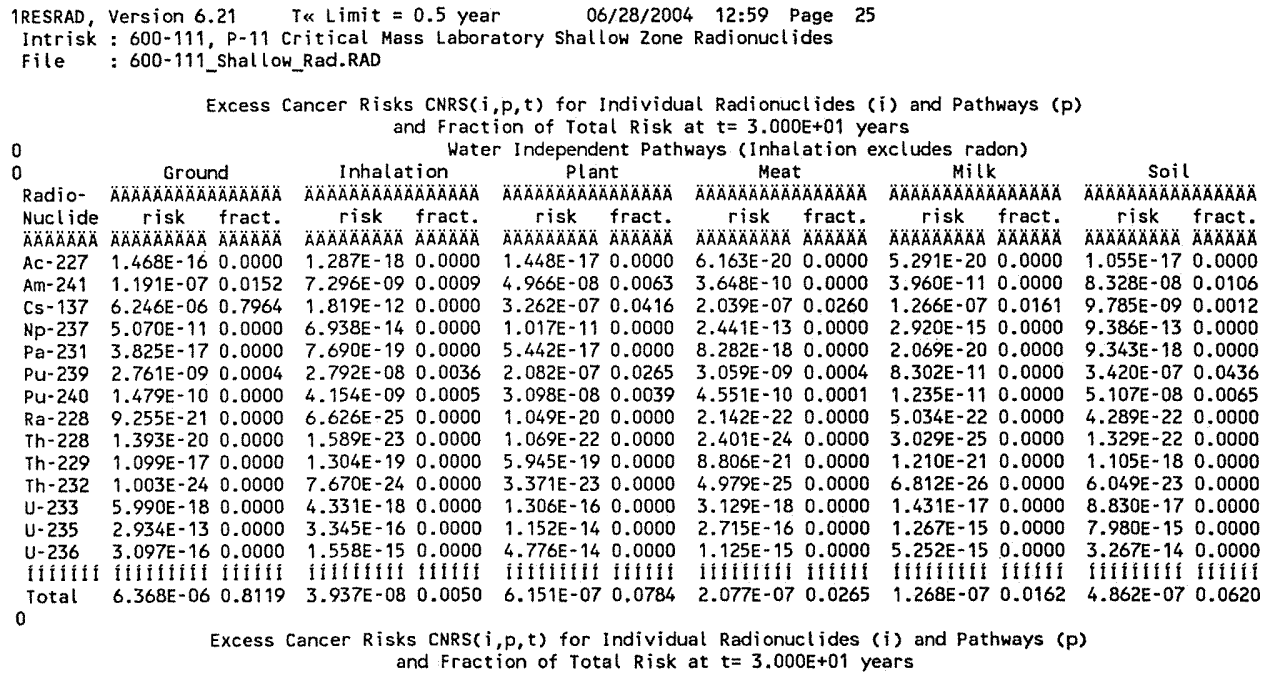

\begin{tabular}{|c|c|}
\hline \multirow{2}{*}{\multicolumn{2}{|c|}{ Attachment $\frac{3}{\text { Originator S.W. Clark }}$ Sheet No. 25 of 39}} \\
\hline & \\
\hline Chk'd By M.T. Stankovich & Date \\
\hline Calc. No. $0600 \mathrm{X}-\mathrm{CA}-\mathrm{V} 0043$ & Rev. No. \\
\hline
\end{tabular}




\section{ATTACHMENT 3}

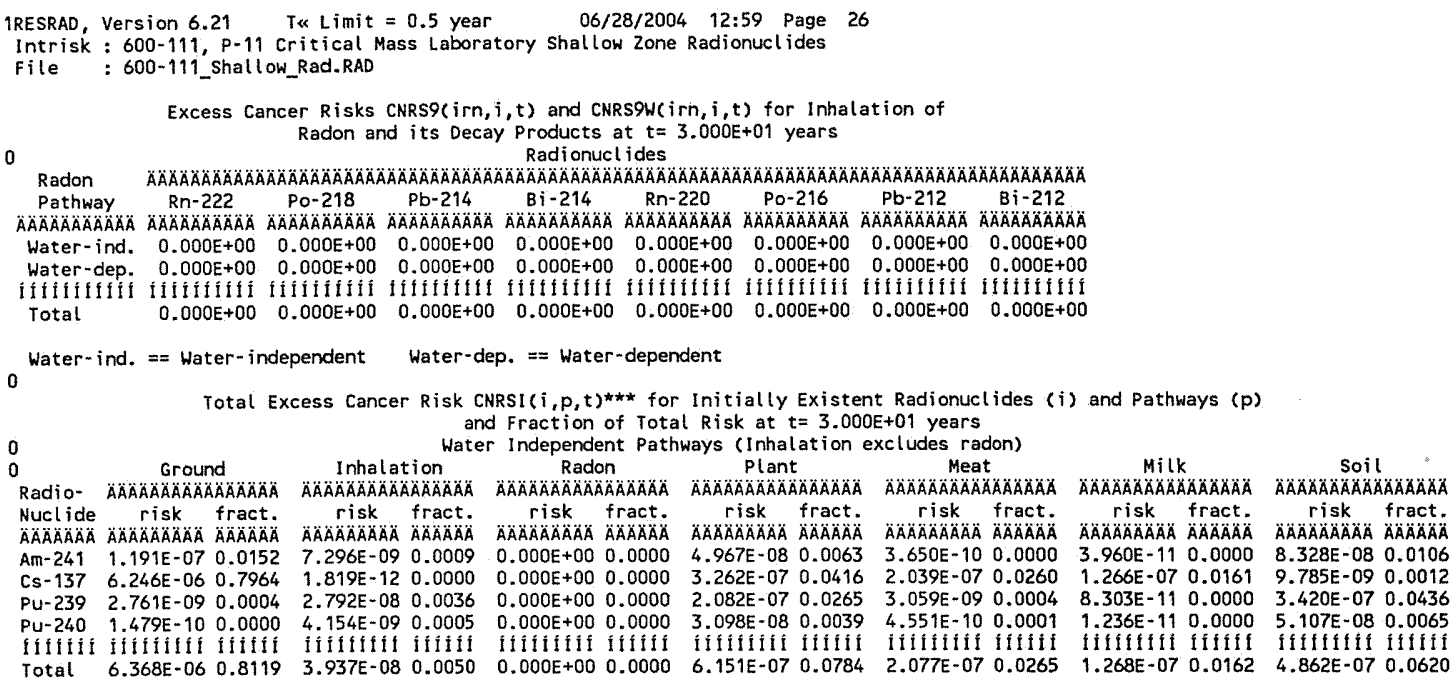

\begin{tabular}{|c|c|}
\hline Attachment & Sheet No. 26 of 39 \\
\hline S.W. Clark & \\
\hline$A-V_{0}$ & \\
\hline
\end{tabular}


ATTACHMENT 3

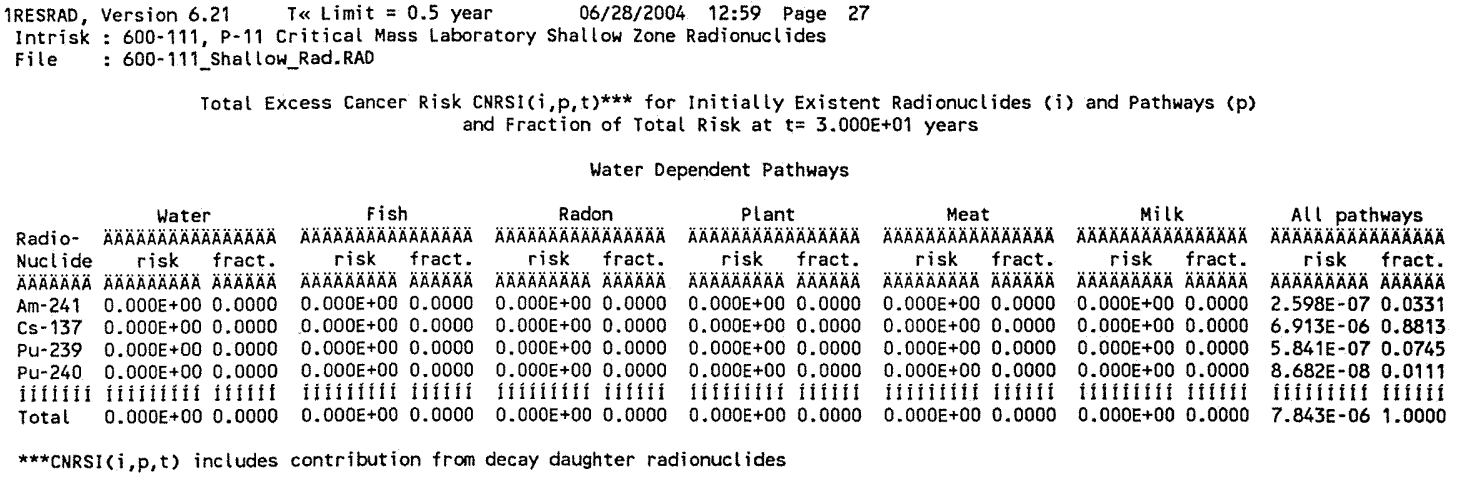




\section{ATTACHMENT 3}

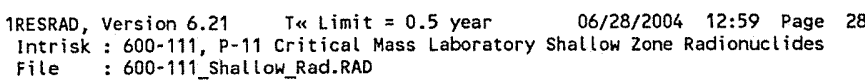




\section{ATTACHMENT 3}

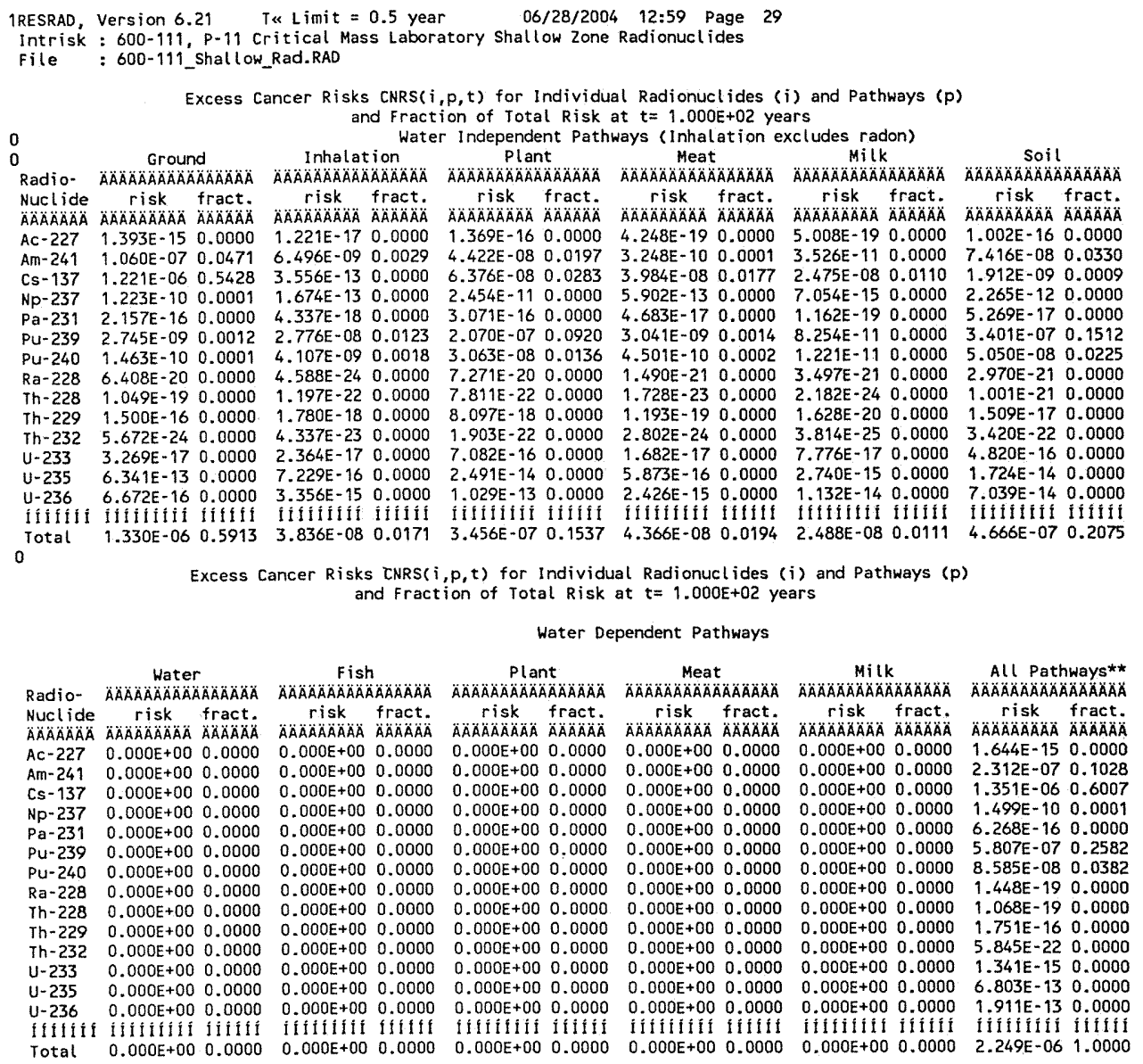

** Sum of water independent ground, inhatation, plant, meat, milk, soil

and water dependent water, fish, plant, meat, milk pathways

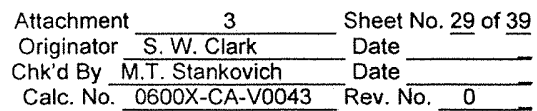




\section{ATTACHMENT 3}

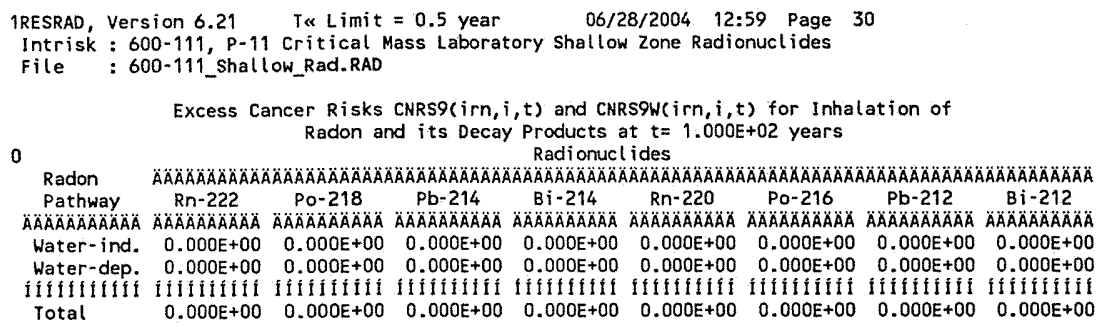




\section{ATTACHMENT 3}

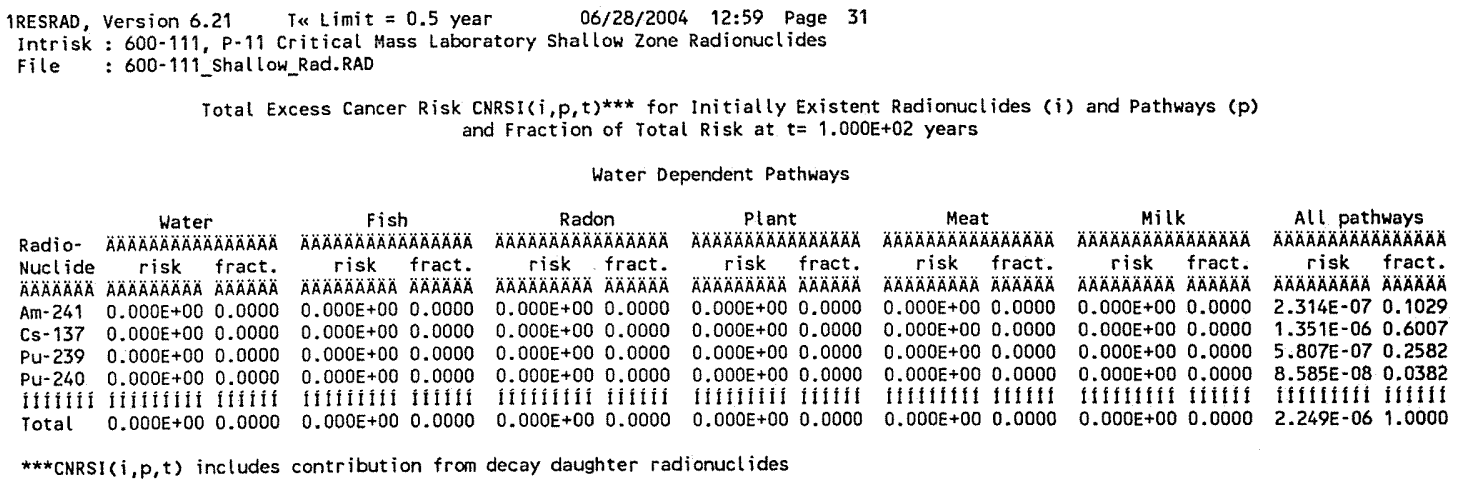

Attachment $\frac{3}{\text { S.W. Slark }}$ Deet No. 31 of 39
Originator
Chk'd By M.T. Stankovich
Date
Calc. No. 0600 N-CA-V0043 Rev. No. 0




\section{ATTACHMENT 3}

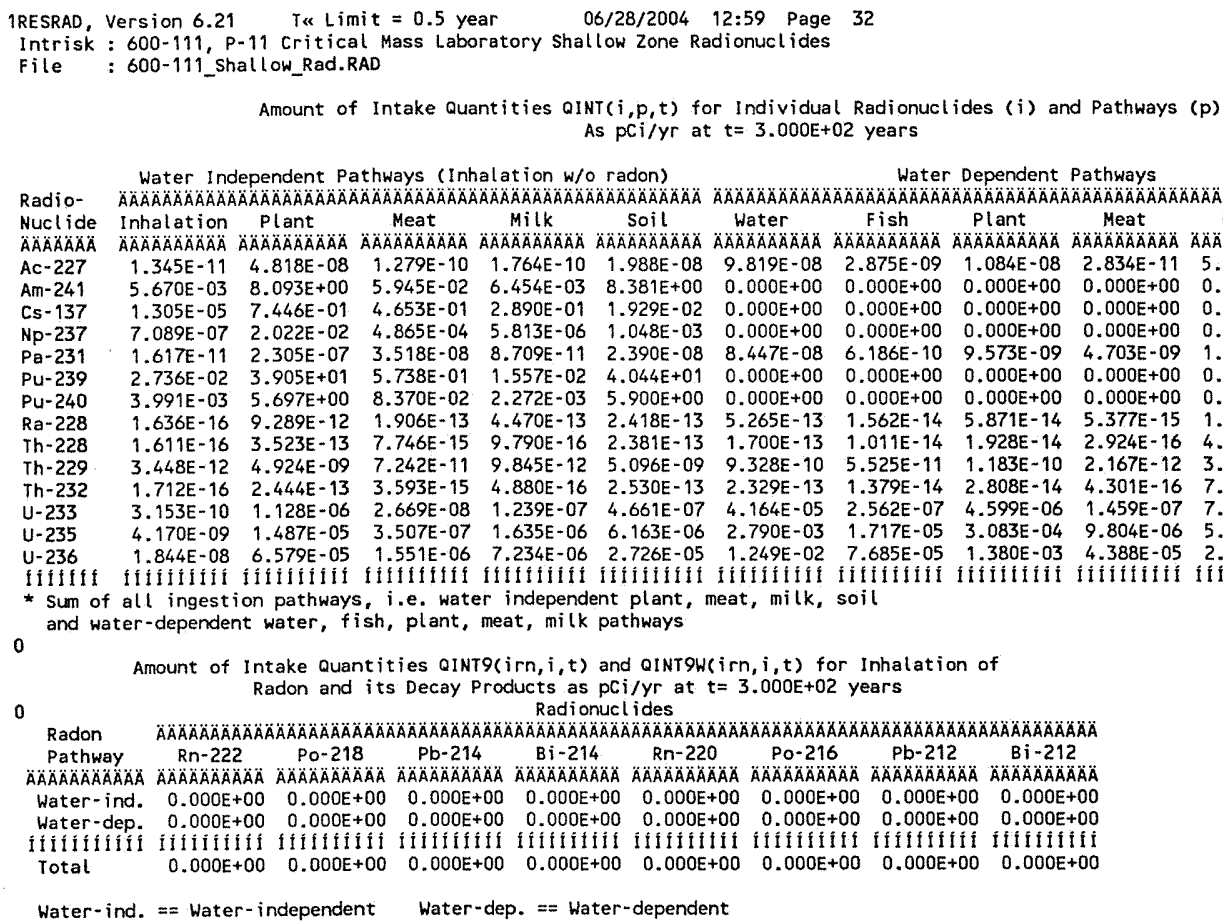

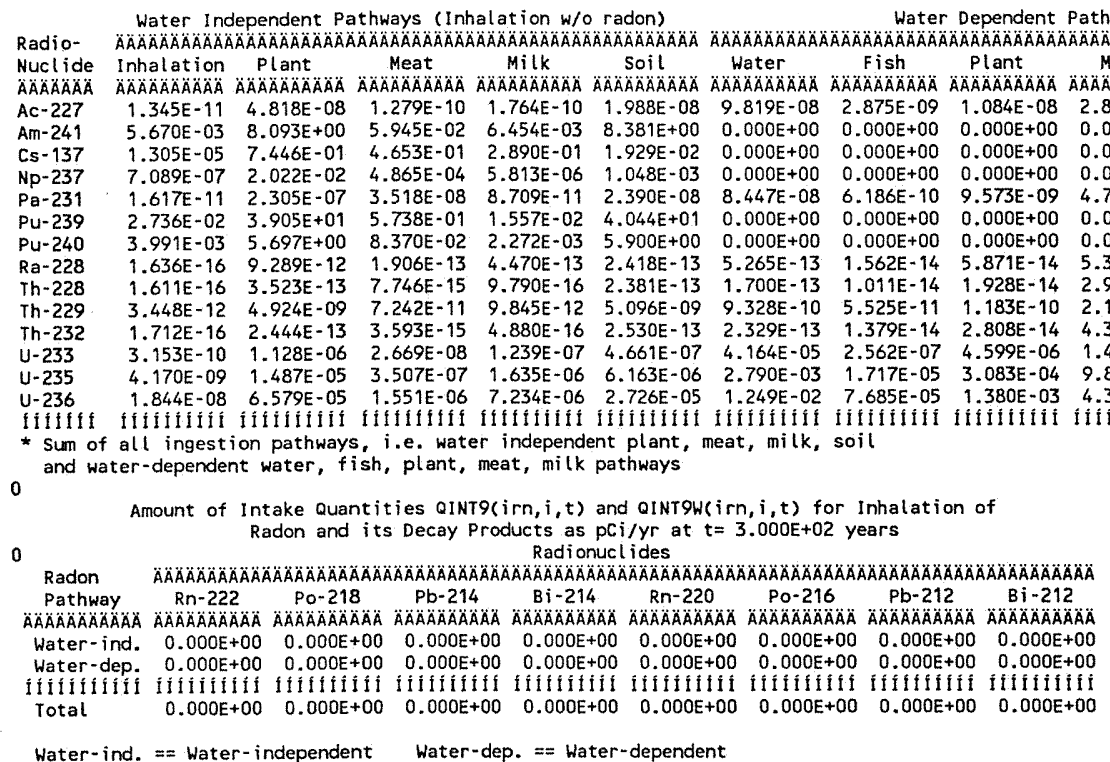




\section{ATTACHMENT 3}

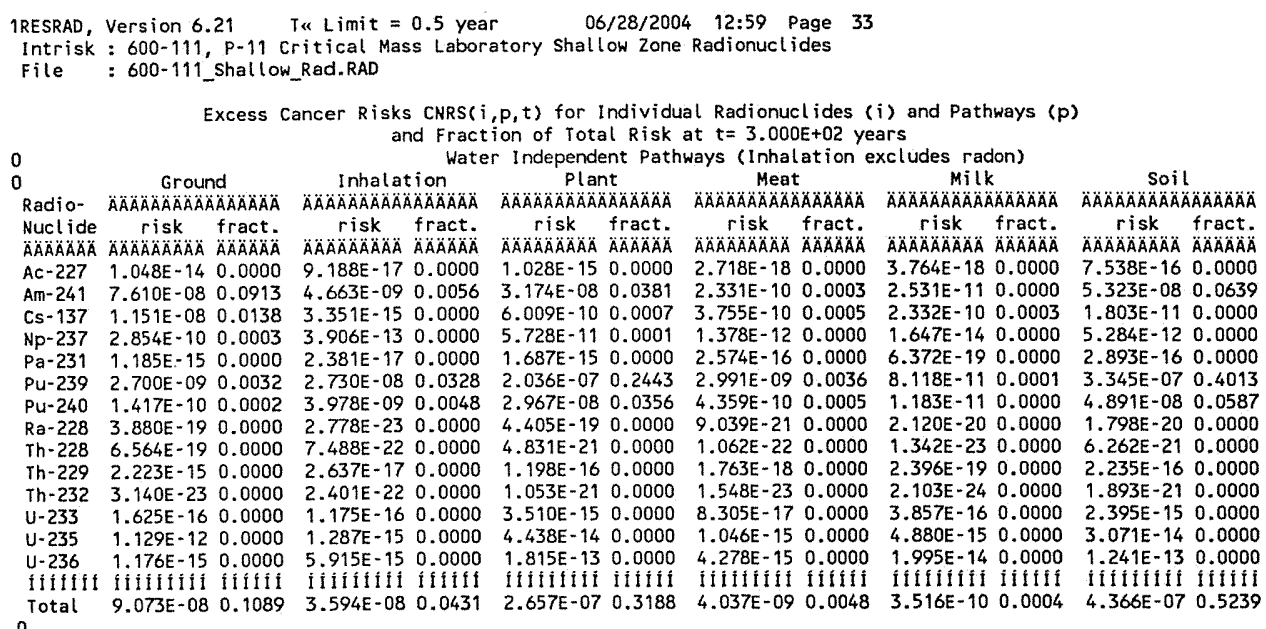

Excess Cancer Risks CNRS $(i, p, t)$ for Individual Radionuclides (i) and Pathways ( $p$ )

and Fraction of Total Risk at $t=3.000 E+02$ years

Water Dependent Pathways

\begin{tabular}{|c|c|c|c|c|c|c|c|c|c|c|c|c|}
\hline & $\begin{array}{r}\text { Water } \\
\triangle A B A A B A A A O A O A\end{array}$ & ÄÄÄÄÄA & $\begin{array}{r}\text { Fish } \\
\triangle A A A A A A O A B A\end{array}$ & AAAAAAA & $\begin{array}{r}\text { Plan } \\
\text { ÄÄÄÄAOAOAOAOA }\end{array}$ & $\begin{array}{l}n t \\
\triangle A A A B A B A\end{array}$ & $\begin{array}{r}\text { Meat } \\
\triangle A A A A A B A A B A\end{array}$ & ÄÄÄÄÄ̈ & $\begin{array}{r}M i l K \\
\triangle \triangle A O A A O A A O A B\end{array}$ & 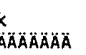 & $\begin{array}{r}\text { All Path } \\
A A B A A B A B A B\end{array}$ & 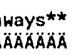 \\
\hline 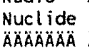 & 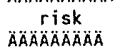 & $\begin{array}{l}\text { fract. } \\
\triangle A B A A B A B\end{array}$ & $\begin{array}{c}\text { risk } \\
\text { AAAOAAAABA }\end{array}$ & $\begin{array}{l}\text { fract. } \\
A A A O A O A O A\end{array}$ & $\begin{array}{c}\text { risk } \\
\text { AAAAOAOAAAAOA }\end{array}$ & $\begin{array}{l}\text { fract. } \\
A B A B A B A\end{array}$ & $\begin{array}{c}\text { risk } \\
\text { ANAAAAAAAA }\end{array}$ & $\begin{array}{l}\text { fract. } \\
A A B A A B A O A\end{array}$ & $\begin{array}{c}\text { risk } \\
\triangle A A B A B A B A A\end{array}$ & $\begin{array}{l}\text { fract. } \\
\text { AAAOAOAOA }\end{array}$ & $\begin{array}{c}\text { risk } \\
\text { ÄAÄAOAOAAA }\end{array}$ & $\begin{array}{l}\text { fract: } \\
\text { ÄAAOAAOA }\end{array}$ \\
\hline$A C-227$ & $2.468 \mathrm{E}-15$ & 0.0000 & $9.712 E-17$ & 0.0000 & $3.661 E-16$ & 0.0000 & $9.211 E-19$ & 0.0000 & $1.976 \mathrm{E}-18$ & 0.0000 & $1.530 \varepsilon-14$ & 0.0000 \\
\hline$A m-241$ & $0.000 \mathrm{E}+00$ & 0.0000 & $0.000 E+00$ & 0.0000 & $0.000 E+00$ & 0.0000 & $0.000 E+00$ & 0.0000 & $0.000 E+00$ & 0.0000 & $1.660 \mathrm{E}-07$ & 0.1992 \\
\hline Cs -137 & $0.000 E+00$ & 0.0000 & $0.000 E+00$ & 0.0000 & $0.000 E+00$ & 0.0000 & $0.000 E+00$ & 0.0000 & $0.000 E+00$ & 0.0000 & $1.273 \mathrm{E}-08$ & 0.0153 \\
\hline$N p-237$ & $0.000 E+00$ & 0.0000 & $0.000 E+00$ & 0.0000 & $0.000 E+00$ & 0.0000 & $0.000 E+00$ & 0.0000 & $0.000 E+00$ & 0.0000 & $3.498 E-10$ & 0.0004 \\
\hline $\mathrm{Pa}-231$ & $6.645 E-16$ & 0.0000 & $6.346 E-18$ & 0.0000 & $9.794 E-17$ & 0.0000 & $4.763 E-17$ & 0.0000 & $1.592 \mathrm{E}-19$ & 0.0000 & $4.259 E-15$ & 0.000 \\
\hline Pu-239 & $0.000 E+00$ & 0.0000 & $0.000 E+00$ & 0.0000 & $0.000 E+00$ & 0.0000 & $0.000 E+00$ & 0.0000 & $0.000 E+00$ & 0.0000 & $5.711 E-07$ & 0.685 \\
\hline Pu- 240 & $0.000 E+00$ & 0.0000 & $0.000 E+00$ & 0.0000 & $0.000 E+00$ & 0.0000 & $0.000 E+00$ & 0.0000 & $0.000 \mathrm{E}+00$ & 0.0000 & $8.314 E-08$ & 0.09 \\
\hline $\mathrm{Ra}-228$ & $2.613 E-20$ & 0.0000 & $1.078 \mathrm{E}-21$ & 0.0000 & 4.051E-21 & 0.0000 & $3.708 \mathrm{E}-22$ & 0.0000 & $1.080 E-21$ & 0.0000 & $9.094 \mathrm{E}-19$ & 0.0000 \\
\hline Th-228 & $2.451 \mathrm{E}-21$ & 0.0000 & $2.049 E-22$ & 0.0000 & $3.906 \mathrm{E}-22$ & 0.0000 & $5.883 E-24$ & 0.0000 & $8.558 \mathrm{E}-25$ & 0.0000 & $6.714 E-19$ & 0.0000 \\
\hline Th-229 & $2.797 \mathrm{E}-17$ & 0.0000 & $2.244 E-18$ & 0.0000 & $4.670 E-18$ & 0.0000 & $7.794 E-20$ & 0.0000 & $1.349 E-20$ & 0.0000 & $2.629 E-15$ & 0.0000 \\
\hline Th-232 & $1.063 \mathrm{E}-21$ & 0.0000 & $8.294 \mathrm{E}-23$ & 0.0000 & $1.658 E-22$ & 0.0000 & $2.349 E-24$ & 0.0000 & $3.911 \mathrm{E}-25$ & 0.0000 & $4.550 E-21$ & 0.0000 \\
\hline$u-233$ & $1.344 E-13$ & 0.0000 & $1.116 E-15$ & 0.0000 & $2.003 E-14$ & 0.0000 & $6.363 E-16$ & 0.0000 & $3.248 E-15$ & 0.0000 & $1.661 E-13$ & 0.0000 \\
\hline$u-235$ & $7.180 E-12$ & 0.0000 & $6.007 E-14$ & 0.0000 & $1.079 E-12$ & 0.0000 & $3.432 \mathrm{E}-14$ & 0.0000 & $1.750 E-13$ & 0.0000 & $9.740 \varepsilon-12$ & 0.0000 \\
\hline$u-236$ & $2.997 E-11$ & 0.0000 & $2.486 E-13$ & 0.0000 & $4.464 E-12$ & 0.0000 & $1.420 E-13$ & 0.0000 & $7.242 \mathrm{E}-13$ & 0.0000 & $3.589 E-11$ & 0.0000 \\
\hline fifiliti & ilifilitit & IIffif & IIIIIAIS & fifili & Ditifit & Iffiti & finifili & jiffif & tififitit & fillif & fiflififi & Iftifi \\
\hline & $3.729 \mathrm{E}-11$ & 0.0000 & $3.099 E-13$ & 0.0000 & $5.563 E-12$ & 0.0000 & $1.770 E-13$ & 0.0000 & $9.025 E-13$ & 0.0000 & $8.334 E-07$ & 1.0000 \\
\hline
\end{tabular}

and water dependent water, fish, plant, meat, milk pathways

\begin{tabular}{|c|c|}
\hline Attachment & Sheet No. 33 of 39 \\
\hline Originator S.W. Clark & Date \\
\hline Chk'd By M.T. Stankovich & Date - \\
\hline Calc. No. $0600 \mathrm{X}$-CA-V0043 & Rev. No. \\
\hline
\end{tabular}




\section{ATTACHMENT 3}

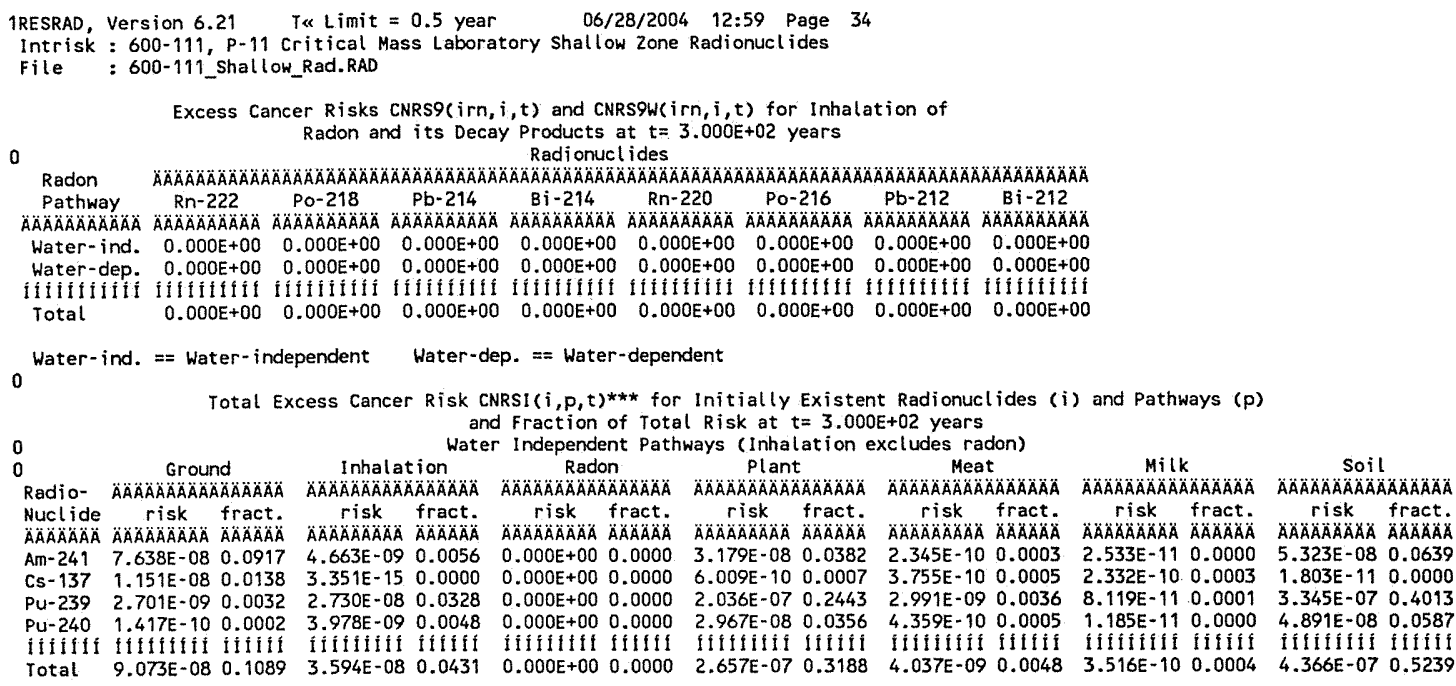

\begin{tabular}{|c|c|}
\hline \multirow{2}{*}{\multicolumn{2}{|c|}{ Attachment $\frac{3}{\text { Originator }}$ S.W. Clark $\quad$ Date No. 34 of 39}} \\
\hline & \\
\hline Chk'd By M.T. Stankovich & Date \\
\hline $0600 X-C A-V 0043$ & 0 \\
\hline
\end{tabular}


ATTACHMENT 3

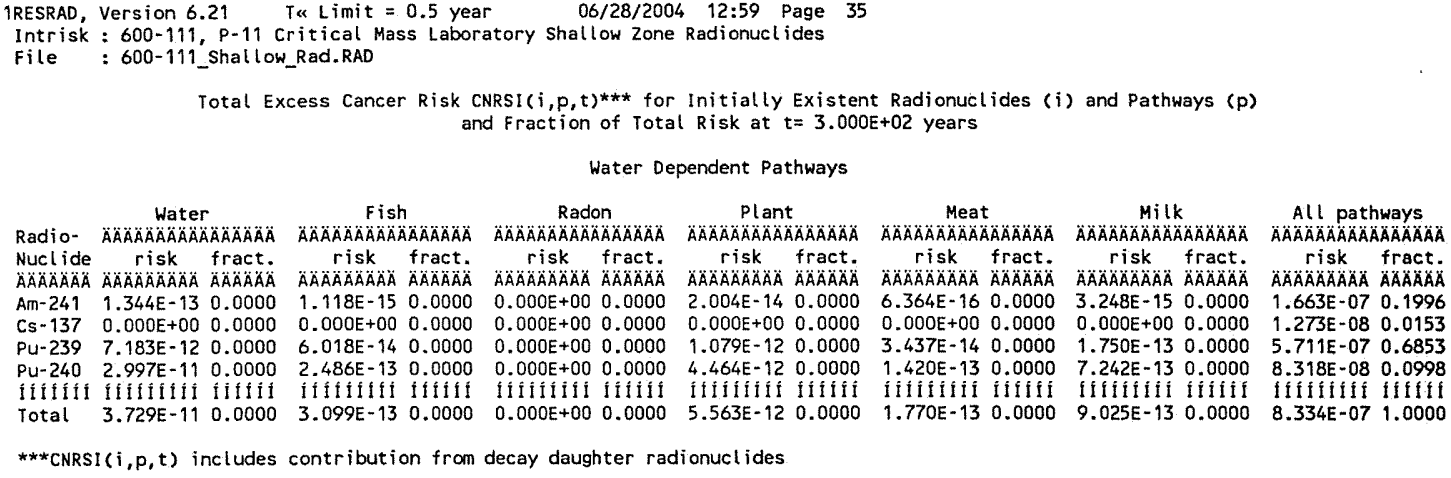

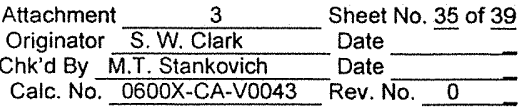




\section{ATTACHMENT 3}

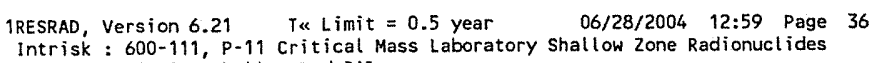

$==$ Water-independent Water-dep. $=$ Water-dependent

Water-ind. = Water - independent

\begin{tabular}{l} 
Attachment $\frac{3}{\text { S.W. Clark }}$ Sheet No. 36 of 39 \\
Originator \\
Chk'd By M.T. Stankovich \\
Date \\
Calc. No. 0600X-CA-V0043 Rev. No. 0 \\
\hline
\end{tabular}




\section{ATTACHMENT 3}

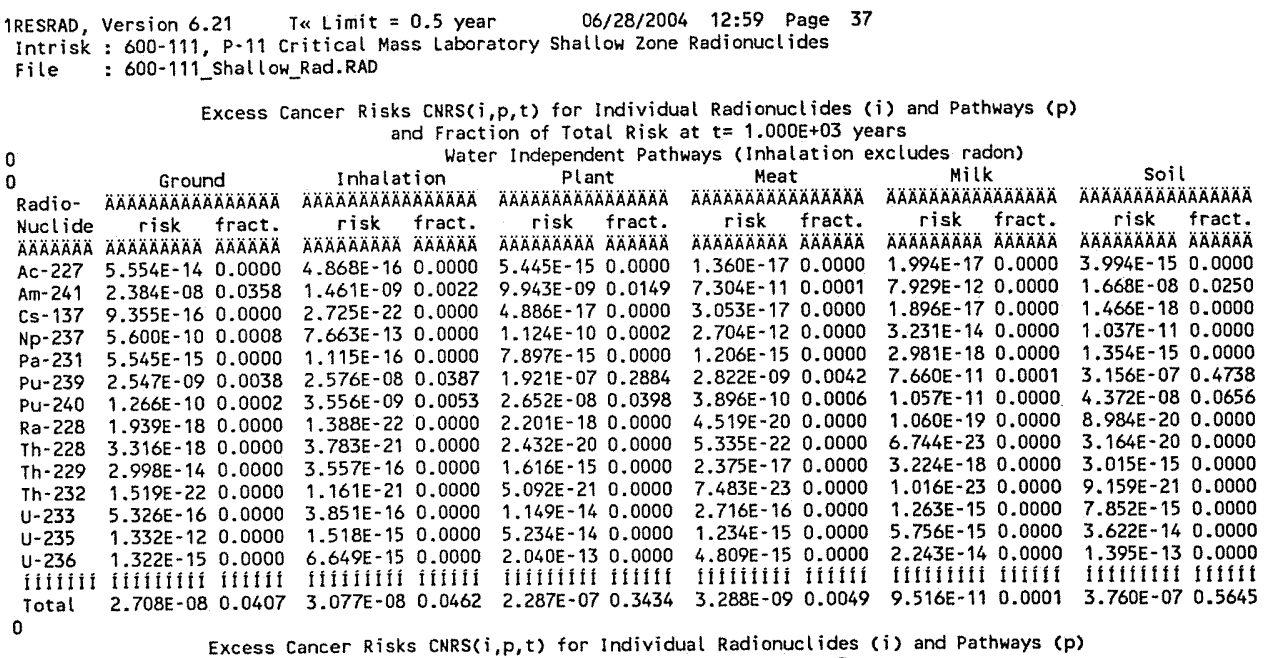

Water Dependent Pathways

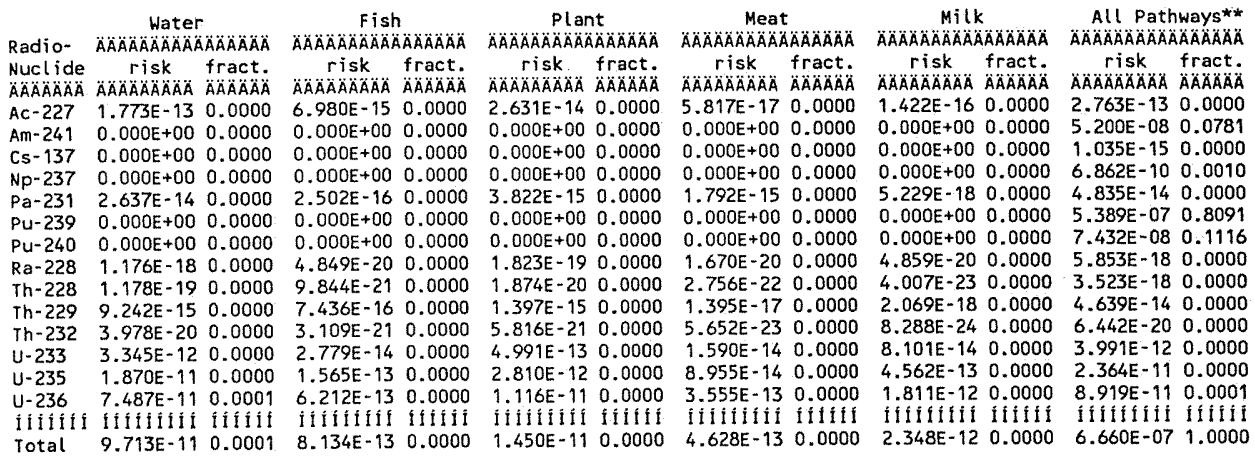

rotal $9.713 \mathrm{E}-11 \quad 0.0001 \quad 8.134 \mathrm{E}-13 \quad 0.0000 \quad 1.450 \mathrm{E}-11 \quad 0.0000 \quad 4.628 \mathrm{E}-13 \quad 0.0000 \quad 2.348 \mathrm{E}-12 \quad 0.0000 \quad 6.660 \mathrm{E}-07 \quad 1.0000$

** Sum of water independent ground, inhalation, plant, meat, milk, soil

and water dependent water, fish, plant, meat, milk pathways

Attachment $\frac{3}{\text { S.W. Clark }}$ Sheet No. 37 of 39
Originator
Chk'd By M.T. Stankovich
Date
Calc. No. 0600X-CA-V0043 Rev. No. 0




\section{ATTACHMENT 3}

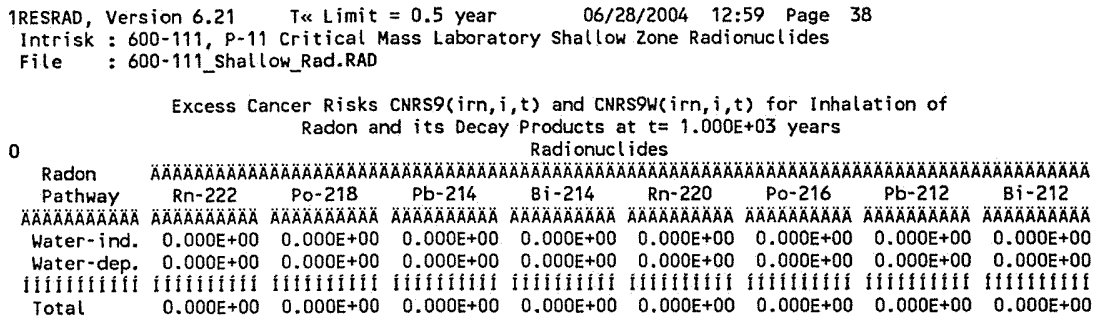

\begin{tabular}{|c|c|}
\hline \multirow{3}{*}{\multicolumn{2}{|c|}{ 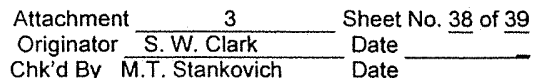 }} \\
\hline & \\
\hline & \\
\hline Calc. No. $0600 X-C A-V 0043$ & Rev. No. \\
\hline
\end{tabular}




\section{ATTACHMENT 3}

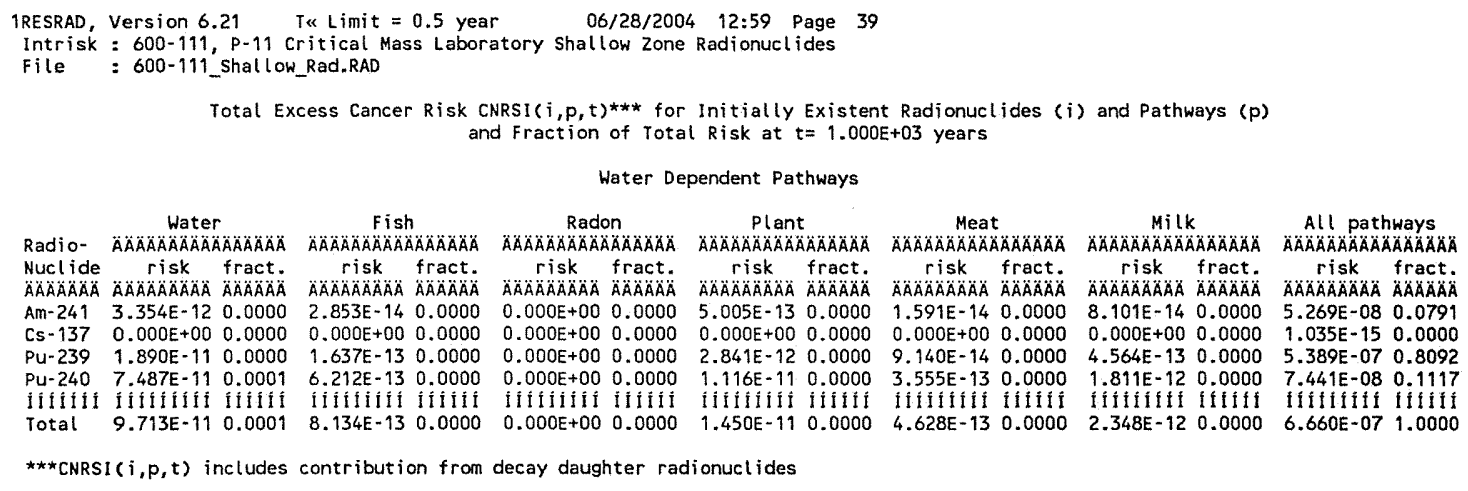




\title{
ATTACHMENT 4
}

\author{
IRESRAD, Version $6.21 \quad T \ll$ Limit $=0.5$ year $\quad 06 / 28 / 2004 \quad 12: 59$ Page \\ Concent : 600-111, P-11 Critical Mass Laboratory Shallow Zone Radionuclides \\ file: $600-111$ shallow Rad.RAD \\ Table of Contents \\ AAAAAAAAAAAAAAAAAA \\ Ifilfififfififitifififilifilift

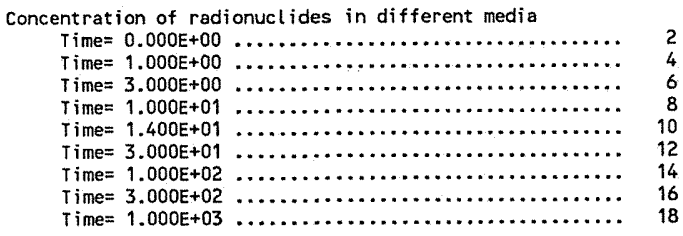

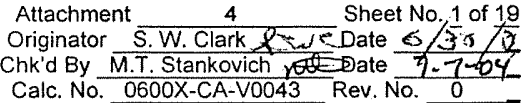




\section{ATTACHMENT 4}

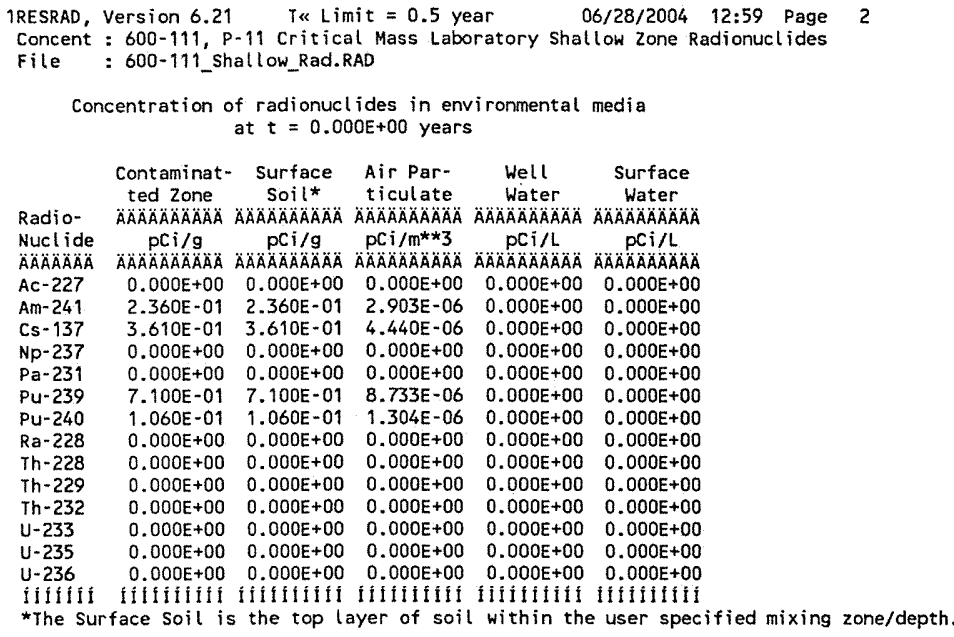

\begin{tabular}{|c|c|}
\hline Attachment $\quad 4$ & Sheet No. 2 of 19 \\
\hline Originator S.W. Clark & Date \\
\hline Chk'd By M.T.Stankovich & Date \\
\hline Calc. No. $0600 \mathrm{X}$-CA-V0043 & Rev. No. \\
\hline
\end{tabular}




\section{ATTACHMENT 4}

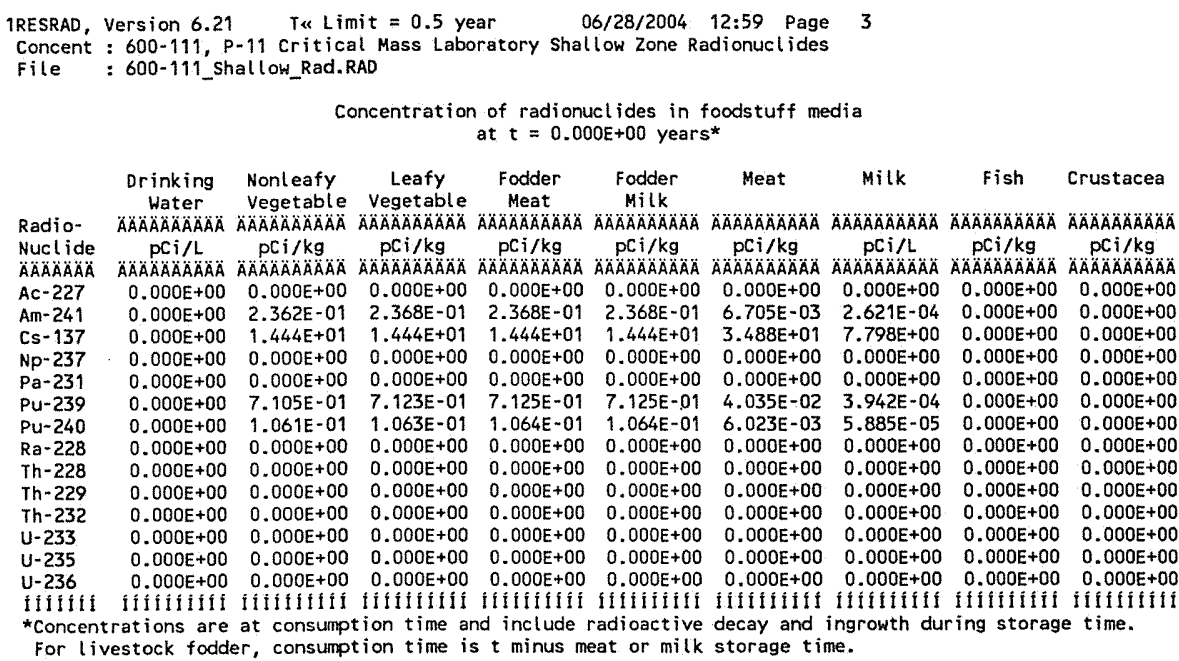

Concentrations in the media occurring in pathways that are suppressed are calculated using the current input parameters, $i$ e. using parameters appearing in the input screen when the pathways are active. 


\section{ATTACHMENT 4}

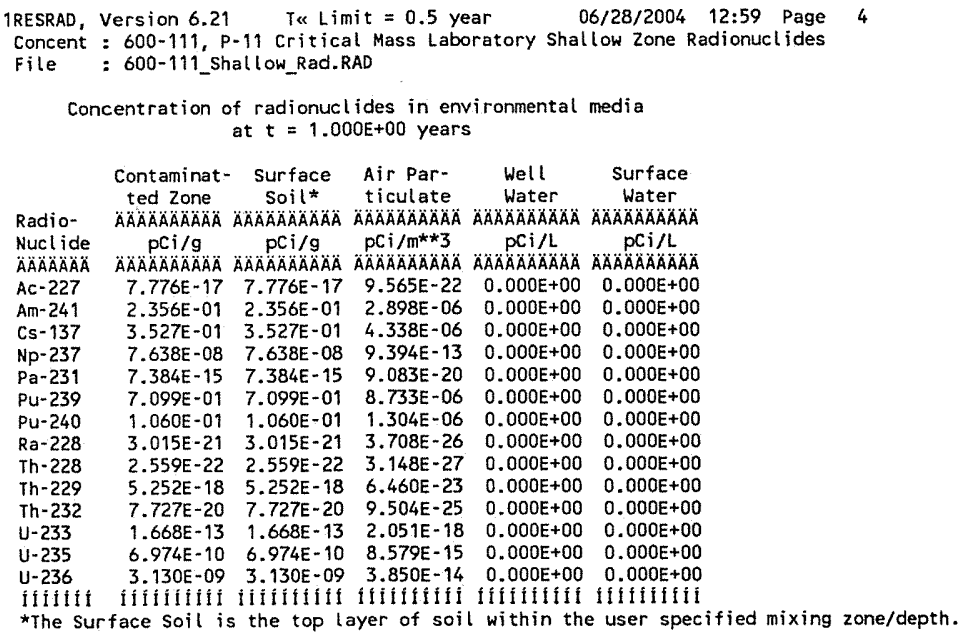

Concentrations in the media occurring in pathways that are suppressed are calculated using the current input parameters, i.e. using parameters appearing in the input screen when the pathways are active.

\begin{tabular}{|c|c|}
\hline Attachment $\quad 4$ & Sheet No. 4 of 19 \\
\hline Originator S.W. Clark & Date \\
\hline Chk'd By M.T. Stankovich & Date \\
\hline Calc. No. $0600 \mathrm{X}$-CA-V0043 & Rev. No. \\
\hline
\end{tabular}




\section{ATTACHMENT 4}

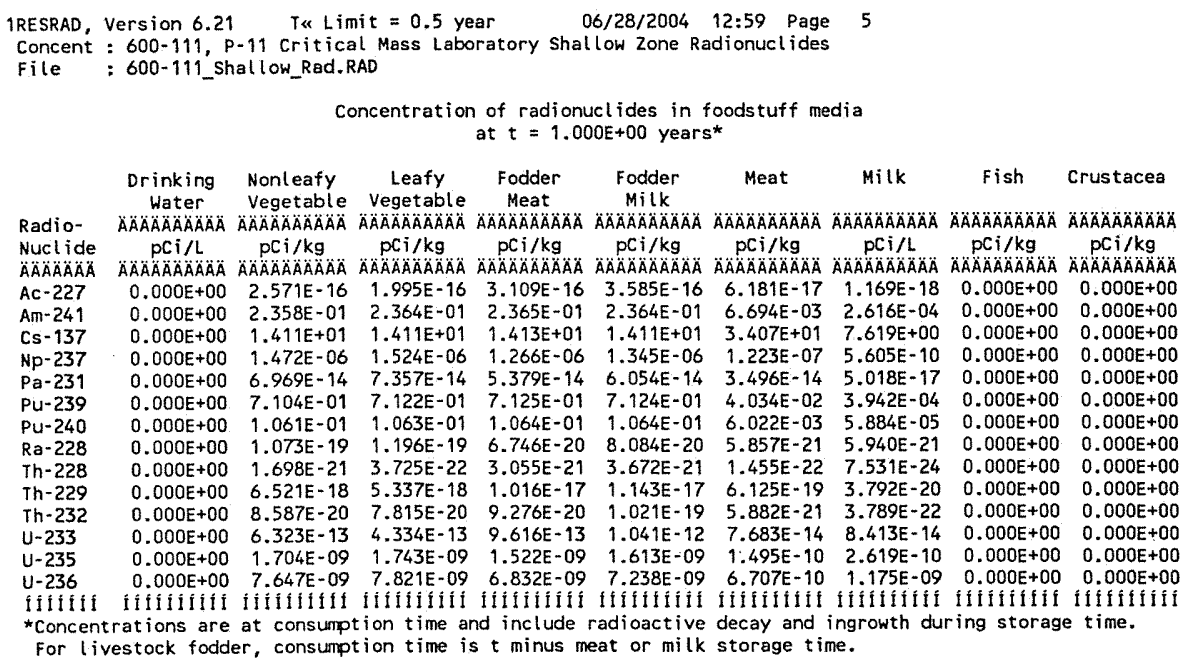

Concentrations in the media occurring in pathways that are suppressed are calculated using the current input parameters, i.e. using parameters appearing in the input screen when the pathways are active. 


\section{ATTACHMENT 4}

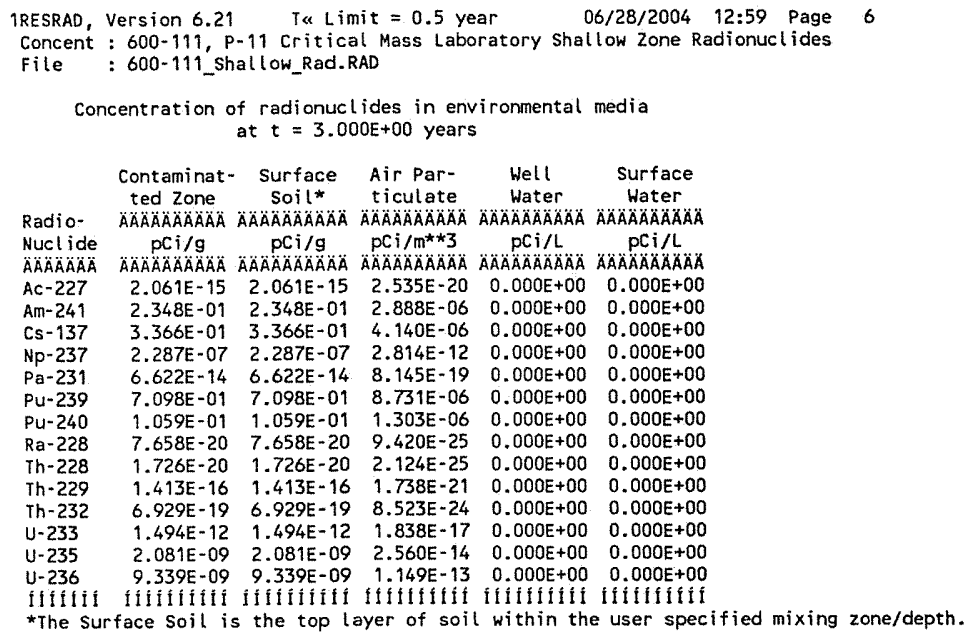

Concentrations in the media occurring in pathways that are suppressed are calculated using the current input parameters, i.e. using parameters appearing in the input screen when the pathways are active.

\begin{tabular}{ll} 
Attachment $\frac{4}{\text { Stiginator S.W. Clark }}$ & Sheet No. $\underline{6}$ of 19 \\
Origin & Date \\
Chk'd By M.T.Stankovich & Date \\
Calc. No. O600X-CA-V0043 Rev. No. 0 \\
\hline
\end{tabular}




\section{ATTACHMENT 4}

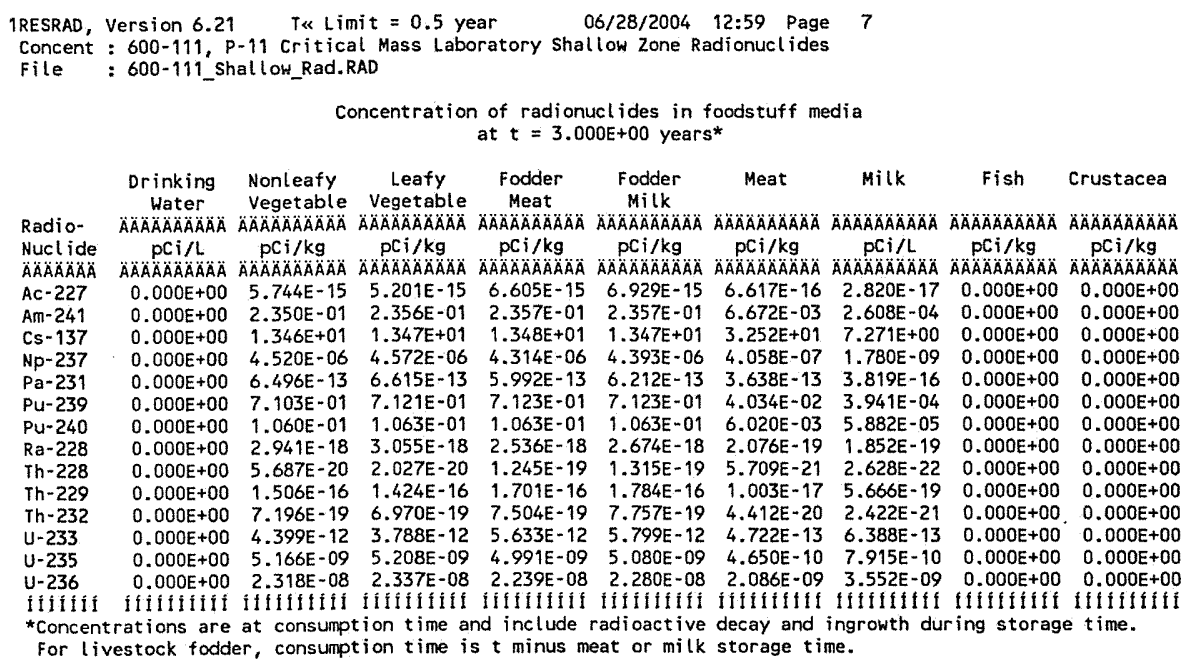

Concentrations in the media occurring in pathways that are suppressed are calculated using the current input parameters, i.e. using parameters appearing in the input screen when the pathways are active.

\begin{tabular}{l} 
Attachment $\frac{4}{\text { S.W. Clark }}$ Sheet No. 7 of 19 \\
Originator \\
Chk'd By M.T. Stankovich \\
Cate \\
Calc. No. 0600 X-CA-V0043 Rev. No. 0 \\
\hline
\end{tabular}




\section{ATTACHMENT 4}

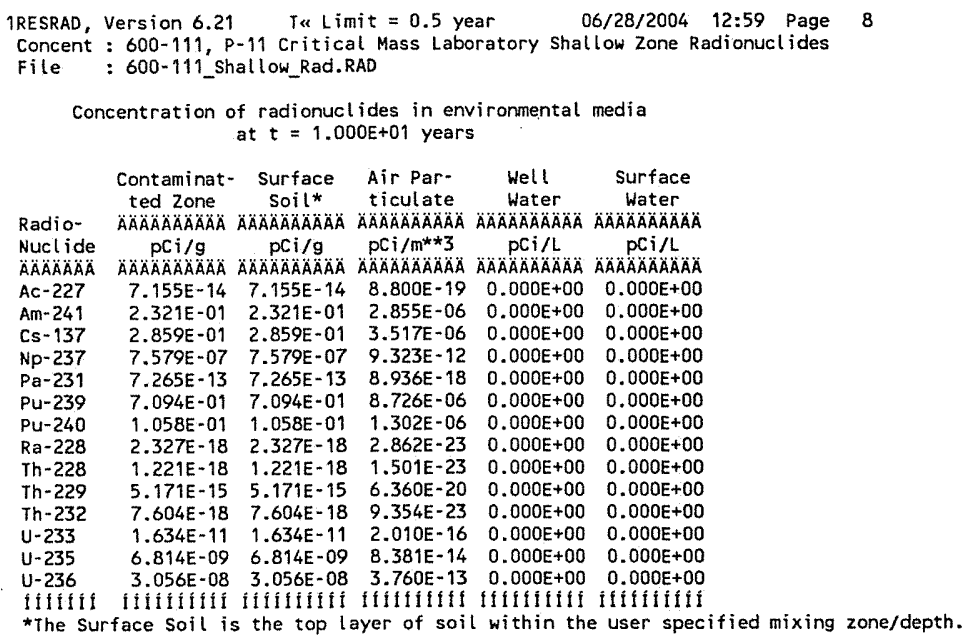

Concentrations in the media occurring in pathways that are suppressed are calculated using the current input parameters, i.e. using parameters appearing in the input screen when the pathways are active.

\begin{tabular}{ll} 
Attachment & \multicolumn{1}{c}{ Sheet No. 8 of 19} \\
Originator S.W. Clark & Date \\
Chk'd By M.T. Stankovich & Date \\
Calc. No. O600X-CA-V0043 Rev. No. & 0 \\
\hline
\end{tabular}




\section{ATTACHMENT 4}

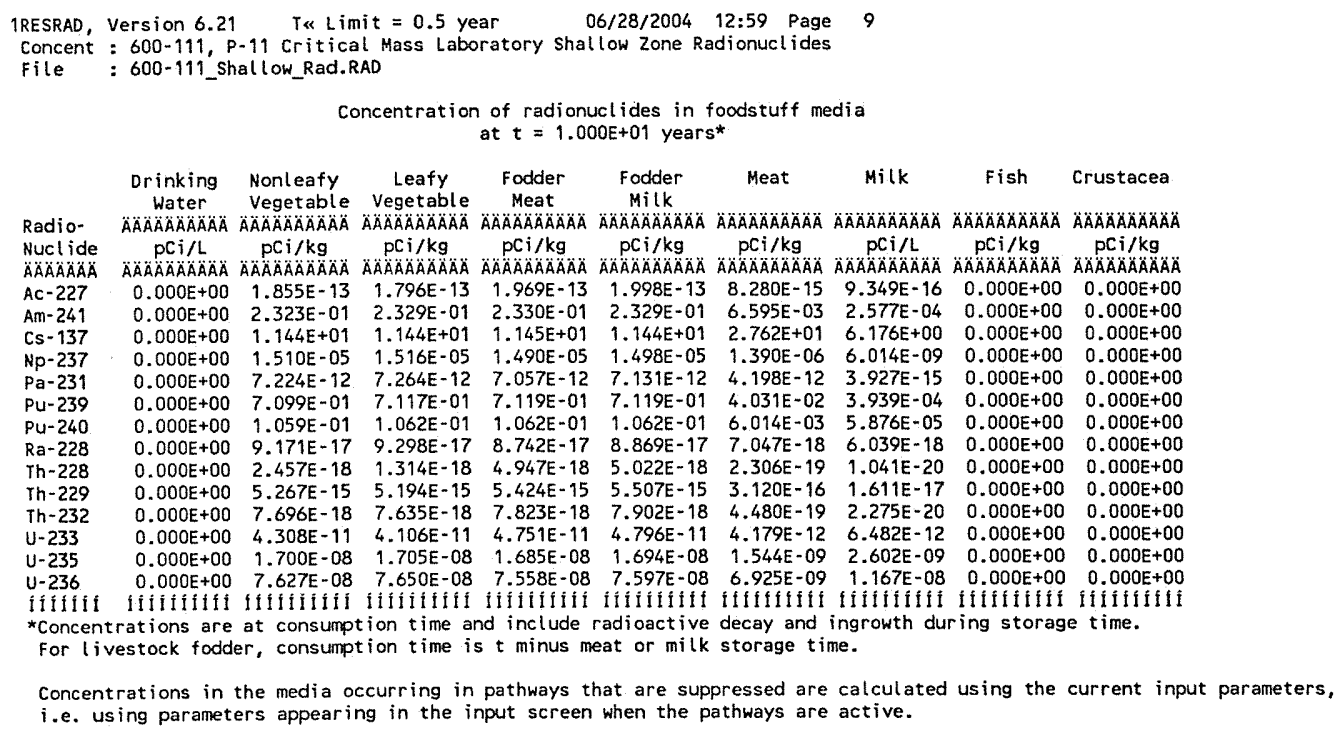

i.e. using parameters appearing in the input screen when the pathways are active.

\begin{tabular}{|c|c|}
\hline Attachment $\quad 4$ & Sheet No. $\underline{9}$ of $1 \mathrm{~s}$ \\
\hline Originator S.W. Clark & Date \\
\hline ink'd By M.T. Stankovich & Date \\
\hline
\end{tabular}




\section{ATTACHMENT 4}

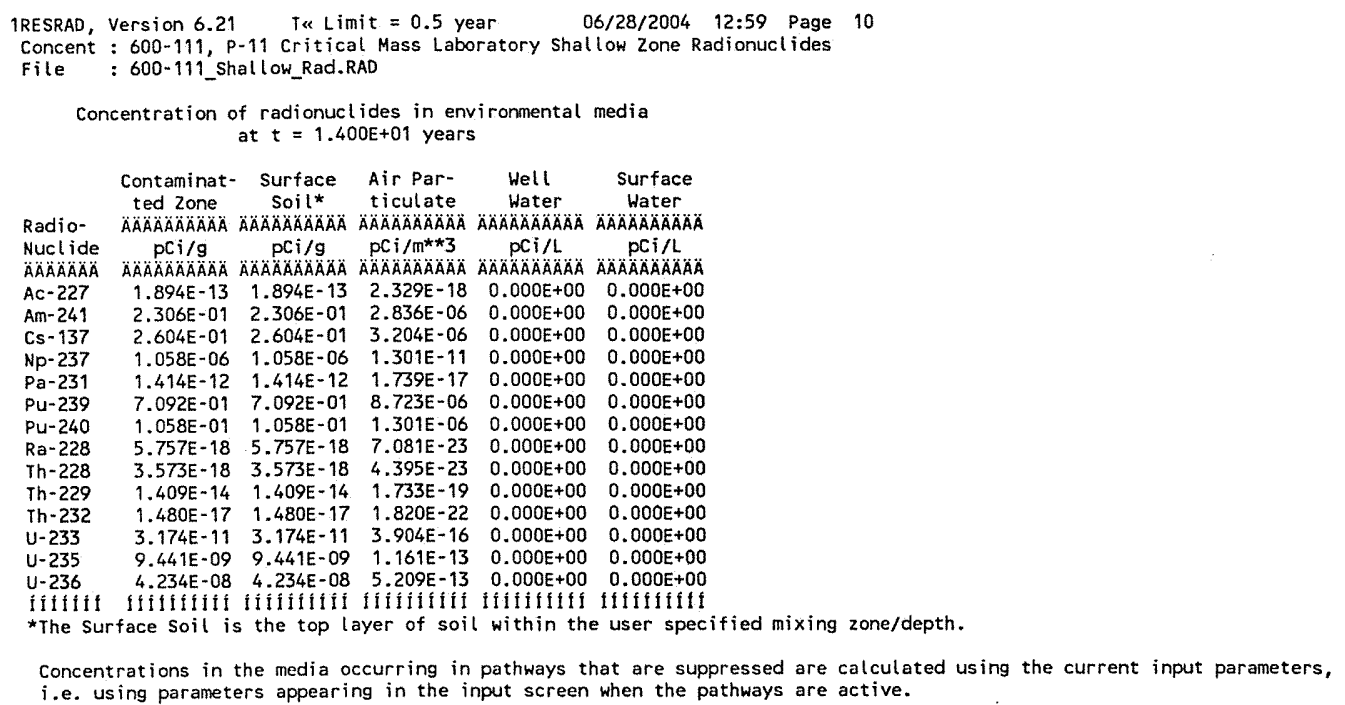

i.e. using parameters appearing in the input screen when the pathways are active.

\begin{tabular}{|c|c|}
\hline ent & et No. 10 of 19 \\
\hline or S.W. Clark & \\
\hline M.T.Stank & \\
\hline 0600 & 0 \\
\hline
\end{tabular}




\section{ATTACHMENT 4}

\begin{tabular}{|c|c|c|c|c|c|c|c|c|c|}
\hline $\begin{array}{l}\text { 1RESRAD, } \\
\text { Concent } \\
\text { File }\end{array}$ & \multicolumn{7}{|c|}{$\begin{aligned} \text { Concentration of radionuclides in foodstuff media } \\
\text { at } t=1.400 E+01 \text { years* }\end{aligned}$} & \multirow[b]{2}{*}{ Fish } & \multirow[b]{2}{*}{ Crustacea } \\
\hline \multirow{3}{*}{$\begin{array}{l}\text { Radio- } \\
\text { Nuclide } \\
\dddot{A B A A O A O A A}\end{array}$} & $\begin{array}{l}\text { Drinking } \\
\text { Water }\end{array}$ & $\begin{array}{l}\text { Nonleafy } \\
\text { Vegetable }\end{array}$ & $\begin{array}{c}\text { Leafy } \\
\text { Vegetable }\end{array}$ & $\begin{array}{l}\text { Fodder } \\
\text { Meat }\end{array}$ & $\begin{array}{l}\text { Fodder } \\
\text { Milk }\end{array}$ & Meat & Milk & & \\
\hline & $\triangle A A O A A A A A A O A O A$ & $\triangle A A A A A A A A A A A B$ & $\triangle A \cap A A A A O A A A A$ & $\triangle A \cap A \triangle A \cap A \cap A \cap A B$ & 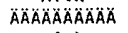 & 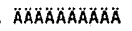 & $\triangle A O A A A A O A O A B A$ & 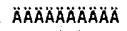 & 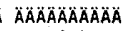 \\
\hline & $\begin{array}{c}P C i / L \\
A A A A A B A B A A\end{array}$ & $\begin{array}{c}\mathrm{pCi} / \mathrm{kg} \\
\triangle A A A B A B A A\end{array}$ & $\begin{array}{c}\mathrm{pCi} / \mathrm{kg} \\
A A A A A B A B A A B\end{array}$ & $\begin{array}{c}p C i / k g \\
A A B A A A A A B A B A\end{array}$ & $\begin{array}{c}\mathrm{pCi} / \mathrm{kg} \\
A A B A A B A B A B\end{array}$ & $\begin{array}{c}\mathrm{pCi} / \mathrm{kg} \\
\triangle A A O A A B A O A O A O A\end{array}$ & $\begin{aligned} \mathrm{pCi} / L \\
A B A B A B A B A B\end{aligned}$ & $\begin{array}{c}\mathrm{pCi} / \mathrm{kg} \\
A A A B A A B A B A\end{array}$ & $\begin{array}{c}p C i / \mathrm{kg} \\
A A B A A A B A O A\end{array}$ \\
\hline $\mathrm{AC}-227$ & $0.000 E+00$ & $4.864 E-13$ & $4.749 \mathrm{E}-13$ & $5.092 E-13$ & $5.146 \mathrm{E}-13$ & $1.687 \mathrm{E}-14$ & $2.459 E-15$ & $0.000 E+00$ & $0.000 E+00$ \\
\hline$A m-241$ & $0.000 E+00$ & $2.307 E-01$ & $2.313 E-01$ & $2.314 \mathrm{E}-01$ & $2.314 \mathrm{E}-01$ & $6.551 E-03$ & $2.560 E-04$ & $0.000 E+00$ & $0.000 E+00$ \\
\hline Cs -137 & $0.000 E+00$ & $1.042 E+01$ & $1.042 E+01$ & $1.043 E+01$ & $1.042 E+01$ & $2.516 \mathrm{E}+01$ & $5.626 \mathrm{E}+00$ & $0.000 E+00$ & $0.000 E+00$ \\
\hline $\mathrm{Np}-237$ & $0.000 E+00$ & $2.110 E-05$ & $2.115 \mathrm{E}-05$ & $2.090 \mathrm{E}-05$ & $2.098 E-05$ & $1.948 \mathrm{E}-06$ & $8.412 E-09$ & $0.000 E+00$ & $0.000 E+00$ \\
\hline$P a-231$ & $0.000 E+00$ & $1.408 E-11$ & $1.414 \mathrm{E}-11$ & $1.385 \mathrm{E}-11$ & $1.395 E-11$ & $8.219 E-12$ & $7.579 E-15$ & $0.000 E+00$ & $0.000 E+00$ \\
\hline Pu-239 & $0.000 E+00$ & $7.097 \mathrm{E}-01$ & $7.115 \mathrm{E}-01$ & $7.117 \mathrm{E}-01$ & $7.117 E-01$ & $4.030 E-02$ & $3.937 \varepsilon-04$ & $0.000 E+00$ & $0.000 E+00$ \\
\hline $\mathrm{Pu}-240$ & $0.000 E+00$ & $1.058 \mathrm{E}-01$ & $1.061 \mathrm{E}-01$ & $1.061 E-01$ & $1.061 E-01$ & $6.010 E-03$ & $5.872 E-05$ & $0.000 E+00$ & $0.000 E+00$ \\
\hline$R a-228$ & $0.000 \mathrm{E}+00$ & $2.276 E-16$ & $2.301 \mathrm{E}-16$ & $2.195 E-16$ & $2.217 E-16$ & $1.767 E-17$ & $1.507 E-17$ & $0.000 E+00$ & $0.000 E+00$ \\
\hline Th-228 & $0.000 E+00$ & $6.642 E-18$ & $3.807 E-18$ & $1.295 \mathrm{E}-17$ & $1.308 E-17$ & $6.075 E-19$ & $2.745 E-20$ & $0.000 E+00$ & $0.000 E+00$ \\
\hline Th-229 & $0.000 E+00$ & $1.428 \mathrm{E}-14$ & $1.415 \mathrm{E}-14$ & $1.458 \varepsilon-14$ & $1.474 E-14$ & $8.350 E-16$ & $4.248 E-17$ & $0.000 E+00$ & $0.000 \mathrm{E}+00$ \\
\hline$T h-232$ & $0.000 E+00$ & $1.493 \mathrm{E}-17$ & $1.486 \mathrm{E}-17$ & $1.512 E-17$ & $1.523 \mathrm{E}-17$ & $8.631 E-19$ & $4.336 E-20$ & $0.000 \mathrm{E}+00$ & $0.000 E+00$ \\
\hline$u-233$ & $0.000 E+00$ & $8.247 \mathrm{E}-11$ & $7.967 \mathrm{E}-11$ & $8.873 E-11$ & $8.935 E-11$ & $7.872 E-12$ & $1.247 \mathrm{E}-11$ & $0.000 E+00$ & $0.000 E+00$ \\
\hline$u-235$ & $0.000 E+00$ & $2.357 E-08$ & $2.363 E-08$ & $2.343 E-08$ & $2.352 E-08$ & $2.143 E-09$ & $3.608 \mathrm{E}-09$ & $0.000 E+00$ & $0.000 E+00$ \\
\hline$u-236$ & $0.000 E+00$ & $1.057 E-07$ & $1.060 \mathrm{E}-07$ & $1.051 E-07$ & $1.055 \mathrm{E}-07$ & $9.611 \mathrm{E}-09$ & $1.618 \mathrm{E}-08$ & $0.000 E+00$ & $0.000 E+00$ \\
\hline fliftit & fifififiti & iffilititi & ifififtif & fiffiftif & ifilififi & iffitifiti & ififitif & fitififitif & ilififiti \\
\hline $\begin{array}{l}\text { *Concent } \\
\text { For liv }\end{array}$ & vestock fodde & $\begin{array}{l}\text { consurif } \\
\text { consumy }\end{array}$ & tion time is & s t minus me & radioactive & decay and $i$ & ime. & & ge time. \\
\hline
\end{tabular}

i.e. using parameters appearing in the input screen when the pathways are active. 


\section{ATTACHMENT 4}

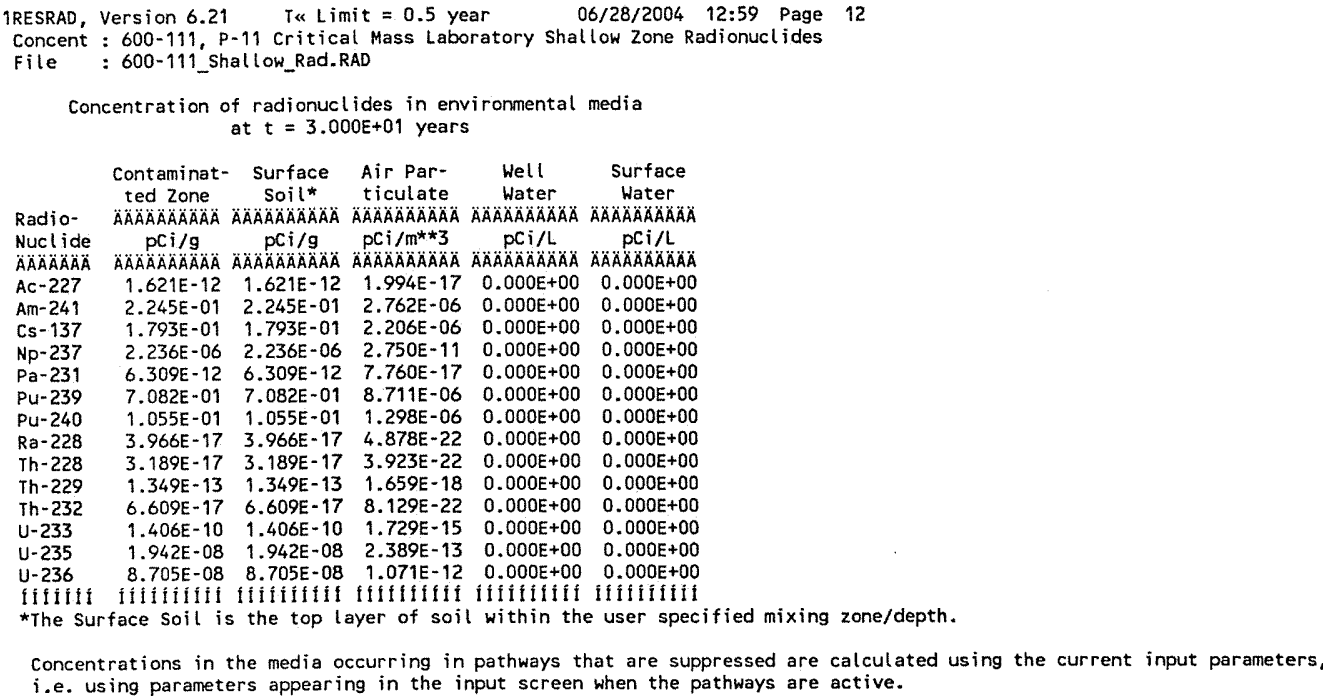




\section{ATTACHMENT 4}

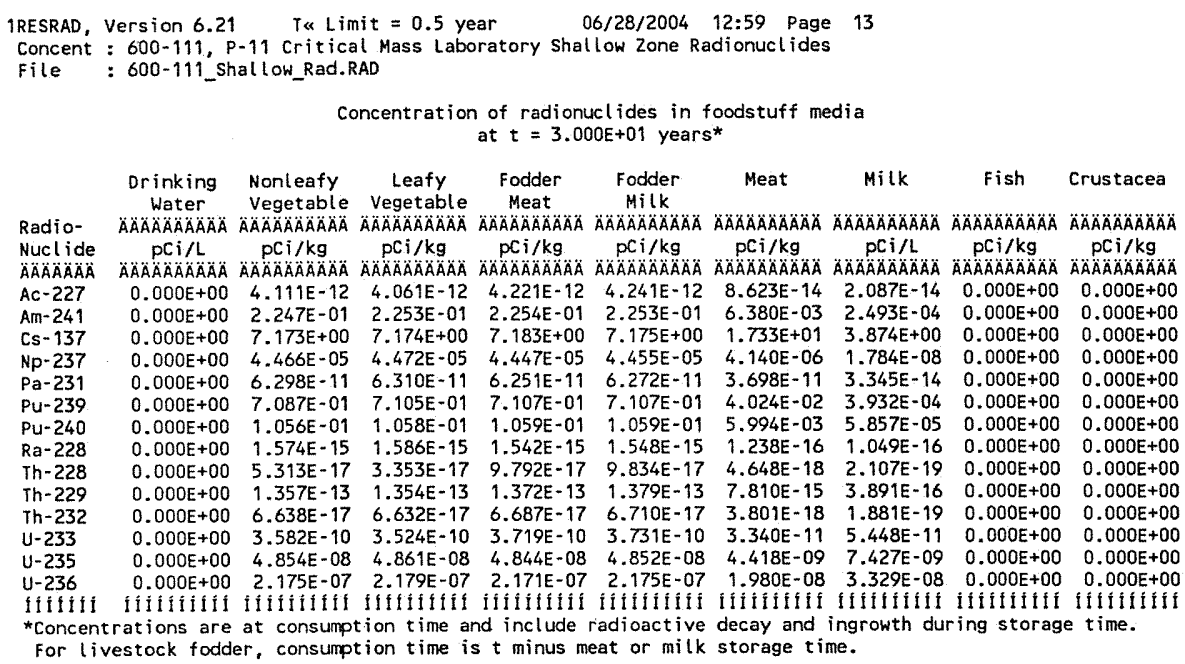

For livestock fodder, consumption time is $t$ minus meat or milk storage time.

Concentrations in the media occurring in pathways that are suppressed are calculated using the current input parameters, i.e. using parameters appearing in the input screen when the pathways are active.

Attachment $\frac{4}{4}$ Sheet No. 13 of 19
Originator S.W. Clark
Date
Chk'd By M.T. Stankovich
Calc. No. 0600 D-CA-V0043 Rev. No. 0
Calc. No




\section{ATTACHMENT 4}

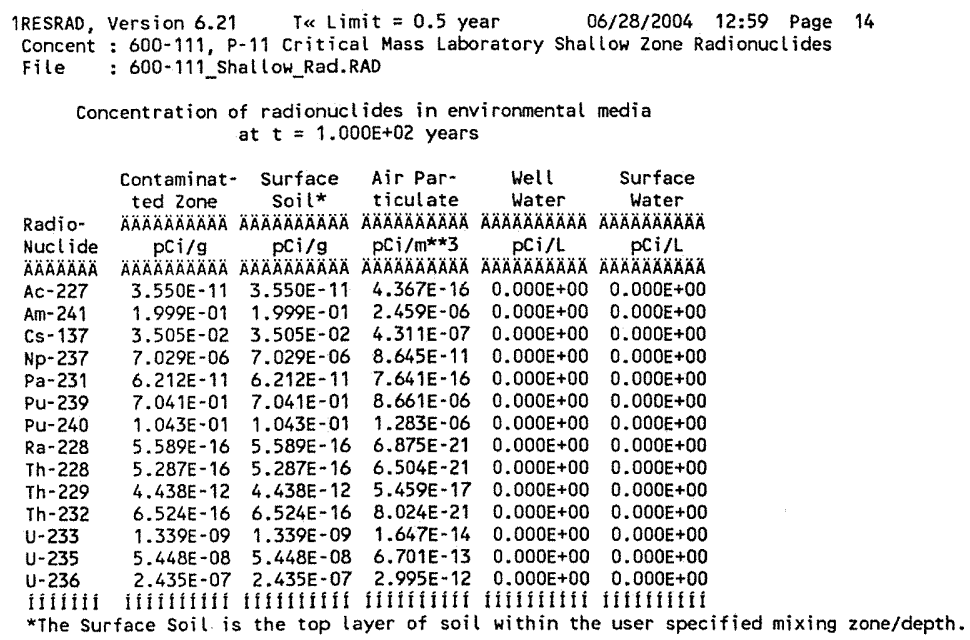

\begin{tabular}{l} 
Attachment $\frac{4}{\text { S.W. Clark }}$ Sheet No. 14 of 19 \\
Originator \\
Chk'd By M.T. Stankovich \\
Date \\
Calc. No. 0600 X-CA-V0043 Rev. No. 0 \\
\hline
\end{tabular}




\section{ATTACHMENT 4}

\begin{tabular}{|c|c|c|c|c|c|c|c|c|c|}
\hline \multirow[t]{3}{*}{$\begin{array}{l}\text { 1RESRAD, } \\
\text { Concent } \\
\text { File }\end{array}$} & \multicolumn{6}{|c|}{$\begin{array}{l}\text { Version } 6.21 \quad \text { T\& Limit }=0.5 \text { year } 06 / 28 / 200412: 59 \text { Page } \\
: 600-111, \text { P-11 critical Mass Laboratory Shallow Zone Radionuclides } \\
: 600-111 \text { Shall ow_Rad.RAD }\end{array}$} & \multicolumn{3}{|l|}{15} \\
\hline & \multicolumn{9}{|c|}{$\begin{array}{c}\text { Concentration of radionuclides in foodstuff media } \\
\text { at } t=1.000 E+02 \text { years* }\end{array}$} \\
\hline & $\begin{array}{l}\text { Drinking } \\
\text { Water }\end{array}$ & $\begin{array}{l}\text { Nonleafy } \\
\text { Vegetable }\end{array}$ & $\begin{array}{l}\text { Leafy } \\
\text { Vegetable }\end{array}$ & $\begin{array}{l}\text { Fodder } \\
\text { Meat }\end{array}$ & $\begin{array}{l}\text { Fodder } \\
\text { Milk }\end{array}$ & Meat & Milk & Fish & Crustacea \\
\hline Radio- & $\triangle A A A \cap A B A A A A B A$ & $\triangle A A A B A A B A A A A B$ & $\triangle A A A A B A A A A A B A$ & $\triangle A A \cap A A A O A A O A O A B$ & $\triangle A \cap A \cap A \cap A B A O A O A$ & $\triangle A \cap A ̈ A Z A A A B A B A$ & 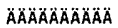 & 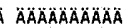 & $\triangle A A A A A O A O A A A$ \\
\hline & pCi/L & & & & & & & & \\
\hline & $\triangle A \cap \triangle A A A A A A A B$ & $\triangle A O A B A O A A A A$ & $\triangle A A A B A A A A B A$ & $\triangle A A O A A A A O A A A A A$ & $\triangle A O A O A O A O A A A A$ & 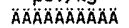 & $\triangle A A A A A A A A A O A A$ & $\triangle A A A O A$ & $\triangle A A A$ \\
\hline$A C-227$ & $0.000 \mathrm{E}+00$ & $8.935 E-11$ & $8.891 E-11$ & $9.059 E-11$ & $9.070 E-11$ & $1.114 \mathrm{E}-12$ & $4.547 E-13$ & $0.000 E+00$ & $0.000 E+00$ \\
\hline & & 2.001 & 2.006 & 2.007E-01 & & & $2.220 \mathrm{E}-04$ & & $0.000 E+00$ \\
\hline & & 1.40 & $1.402 E+00$ & $44 E+00$ & 1.4 & & $7.571 \mathrm{E}$ & & $O E+O D$ \\
\hline $\mathrm{NP}-$ & 0.0 & 1.405 & $1.406 \mathrm{E}-04$ & $1.404 E-04$ & $1,404 E-04$ & $1.306 \mathrm{E}-05$ & $5.619 E-08$ & 0.00 & $O O E+00$ \\
\hline & & 6.20 & 6.21 & 6.1 & 6.2 & & 3.271 & & $\mathrm{E}+00$ \\
\hline & 0.0 & $7.046 \mathrm{E}$ & 7.06 & $7.066 \mathrm{E}-01$ & 7.06 & 4.0 & $3.909 \mathrm{E}$ & 0.0 & $0.000 E+00$ \\
\hline & & 1.04 & $1.047 \mathrm{E}$ & $1.047 \mathrm{E}-$ & $1.047 \mathrm{E}$ & & 5.7 & $+\infty$ & $E+00$ \\
\hline & & 2.22 & $2.235 \mathrm{E}-14$ & $2.196 \mathrm{E}-14$ & $2.198 E-14$ & $1.761 \mathrm{E}-15$ & $1.488 E-15$ & $0.000 \mathrm{E}+00$ & $0.000 E+00$ \\
\hline & $0.000 E+$ & $8.288 \mathrm{E}-16$ & $5.520 E-16$ & $1.471 \mathrm{E}-15$ & $1.473 \mathrm{E}$ & $7.040 \mathrm{E}-$ & $3.201 \mathrm{E}$ & $O E+0 O$ & $0.000 \mathrm{E}+00$ \\
\hline Th & 0.00 & $4.448 E-12$ & $4.453 E-12$ & $4.470 E-12$ & $4.477 E-12$ & $2.535 \mathrm{E}-13$ & $1.246 \mathrm{E}$ & $0.000 \mathrm{E}+00$ & $0.000 \mathrm{E}+00$ \\
\hline & $0.000 \mathrm{E}$ & $6.535 \mathrm{E}-16$ & $6.545 \mathrm{E}-16$ & $6.562 E-16$ & $6.569 E-16$ & $3.720 E-17$ & $1.824 \mathrm{E}$ & $0.000 \mathrm{E}+00$ & $0.000 E+00$ \\
\hline & $0.000 E+00$ & $3.369 E-09$ & $3.353 \mathrm{E}-09$ & $3.417 \mathrm{E}-09$ & $3.420 \mathrm{E}-09$ & $3.095 \mathrm{E}-10$ & $5.145 \mathrm{E}-10$ & $0.000 E+00$ & $0.000 E+00$ \\
\hline$u-235$ & $0.000 \mathrm{E}+00$ & $1.362 E-07$ & $1.364 \mathrm{E}-07$ & $1.363 E-07$ & $1.363 \mathrm{E}-07$ & $1.241 E-08$ & 2.084E-08 & $0.000 \mathrm{E}+00$ & $0.000 \mathrm{E}+00$ \\
\hline$u-236$ & $0.000 E+00$ & $6.088 E-07$ & $6.094 \mathrm{E}-07$ & & & & & & $0.000 E+00$ \\
\hline & & & & & & lifitifif & flififit & Ifitifilit & Ititifiti \\
\hline & & & & & & & & & \\
\hline
\end{tabular}

For livestock fodder, consumption time is $t$ minus meat or milk storage time.

Concentrations in the media occurring in pathways that are suppressed are calculated using the current input parameters, i.e. using parameters appearing in the input screen when the pathways are active.

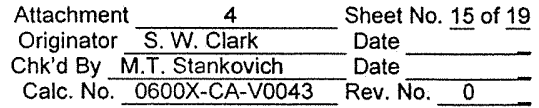




\section{ATTACHMENT 4}

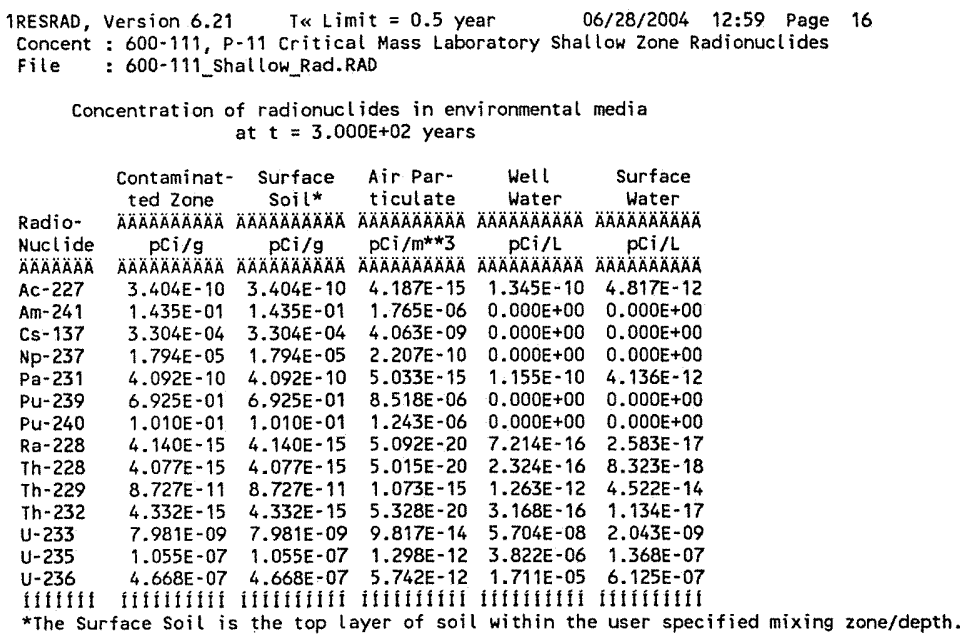

Concentrations in the media occurring in pathways that are suppressed are calculated using the current input parameters, i.e. using parameters appearing in the input screen when the pathways are active.

Attachment $\frac{4}{4}$ Sheet No. 16 of 19
Originator S.W. Clark
Date
Chk'd By M.T. Stankovich
Catc. No. 0600X-CA-V0043 Rev. No.




\section{ATTACHMENT 4}

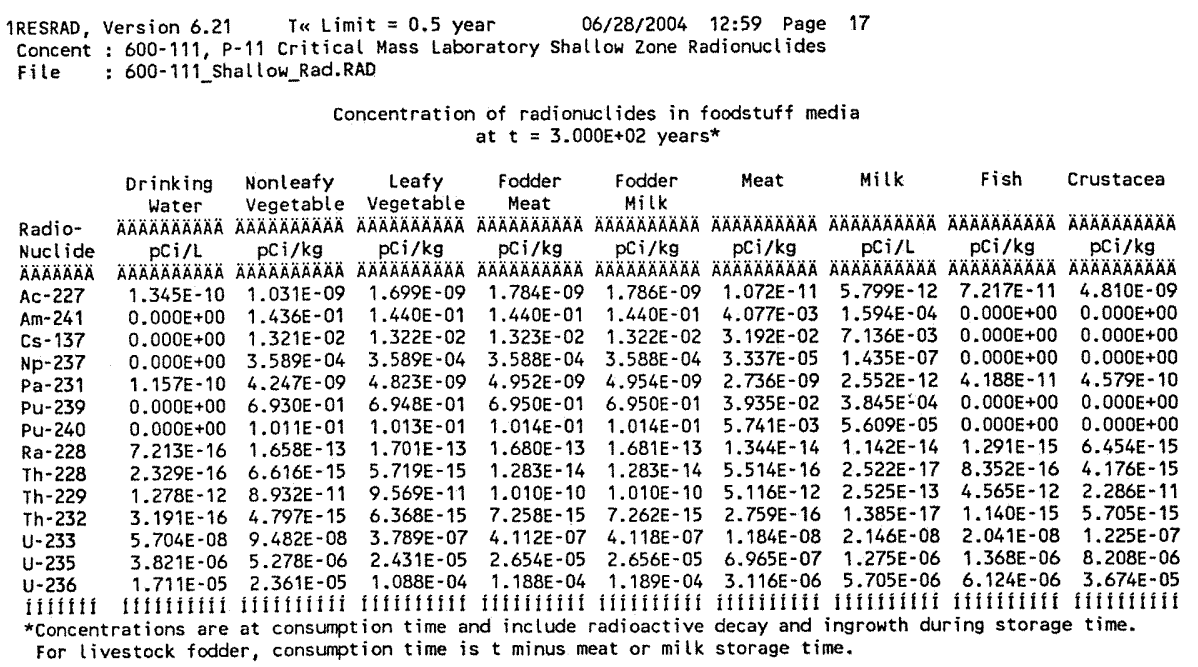

concentrations in the media occurring in pathways that are suppressed are calculated using the current input parameters, i.e. using parameters appearing in the input screen when the pathways are active.

\begin{tabular}{|c|c|}
\hline Attachment 4 & Sheet No. 17 of 19 \\
\hline Originator S.W. Clark & Date - \\
\hline Chk'd By M.T. Stankovich & Date \\
\hline Calc. No. $0600 \mathrm{X}-\mathrm{CA}-\mathrm{V} 0043$ & Rev. No. \\
\hline
\end{tabular}




\section{ATTACHMENT 4}

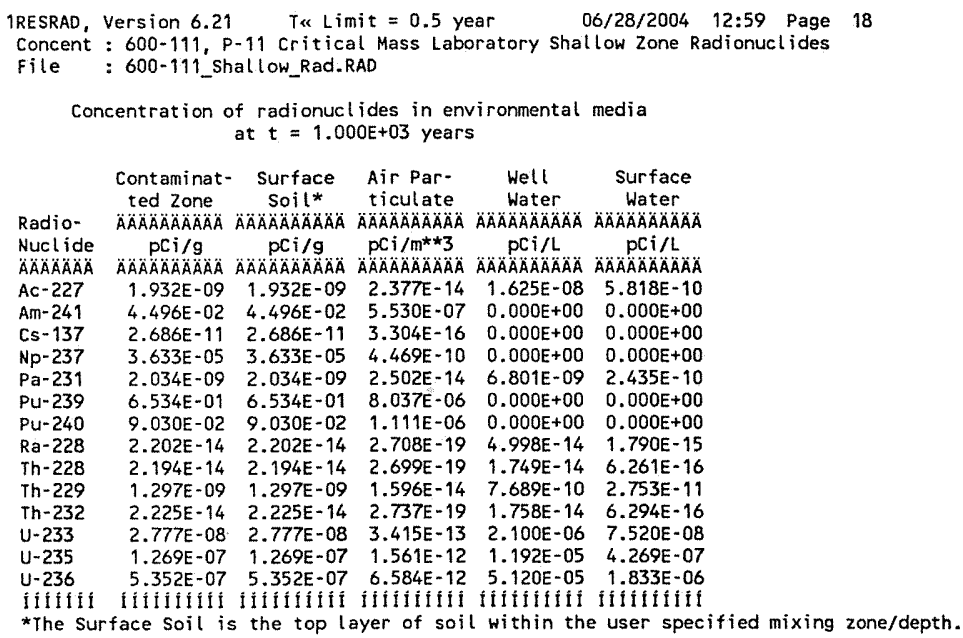




\section{ATTACHMENT 4}

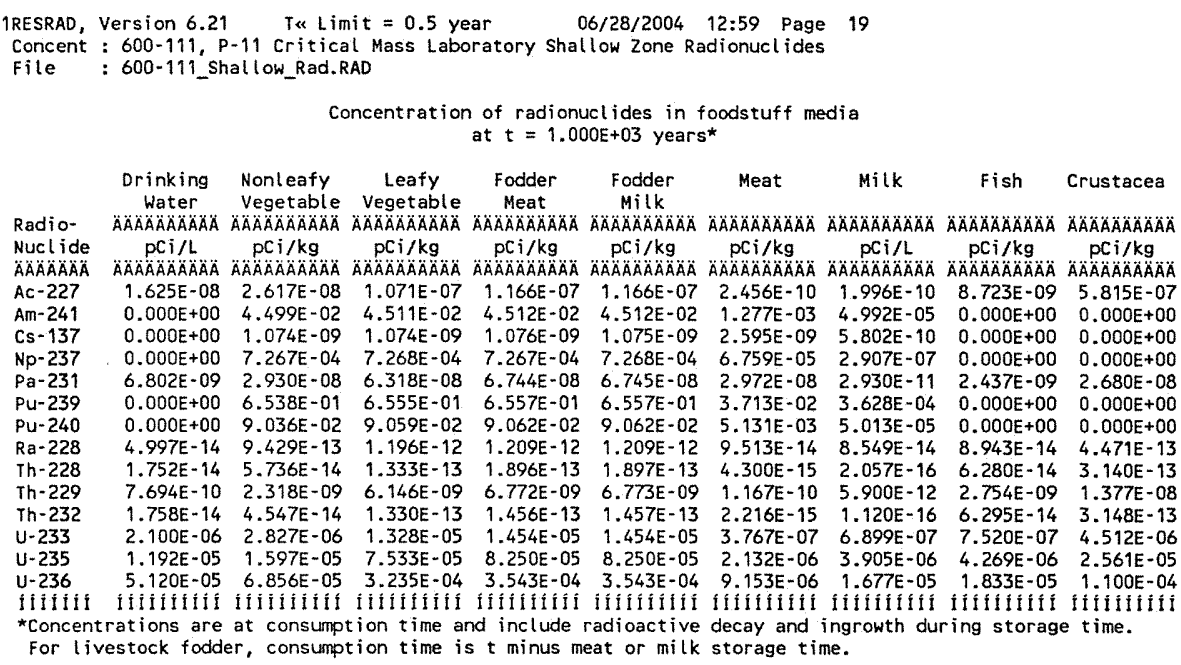

\begin{tabular}{l} 
Attachment $\frac{4}{4}$ Sheet No. 19 of 19 \\
Originator S.W. Clark \\
Chk'd By M.T. Stankovich \\
Date \\
Calc. No. 0600X-CA-V0043 Rev. No. 0 \\
\hline
\end{tabular}

